(4) ง

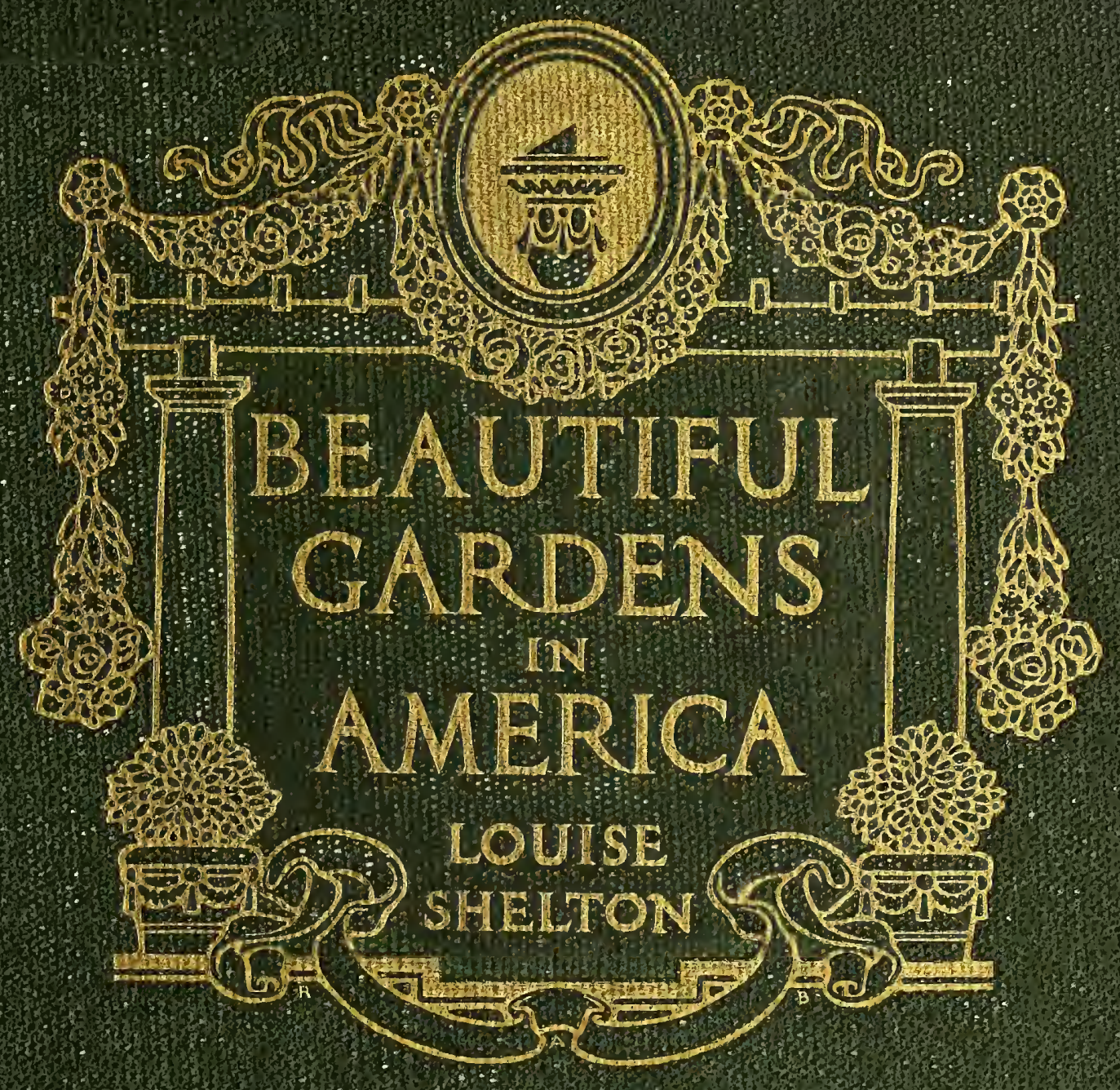


MOCLELLAND \& CO. BOOKSELLERS

$$
\text { COLUMBUS, }=0
$$






\section{BEAUTIFUL GARDENS \\ IN AMERICA}


BOOKS BY LOUISE SHELTON

PUBLISHED BY CHARLES SCRIBNER'S SONS

BEAUTIFUL GaRdens IN AMERICA. IIlustrated. 4 to ...... net $\$ 5.00$ CONTINUOUS BLOOM IN AMERICA. IIlustrated. 4to...... . net $\$ 2.00$ THE SEASONS IN A FLOWER GARDEN.

Illustrated. $12 \mathrm{mo} 0 . \ldots$ net $\$ 1.00$ 



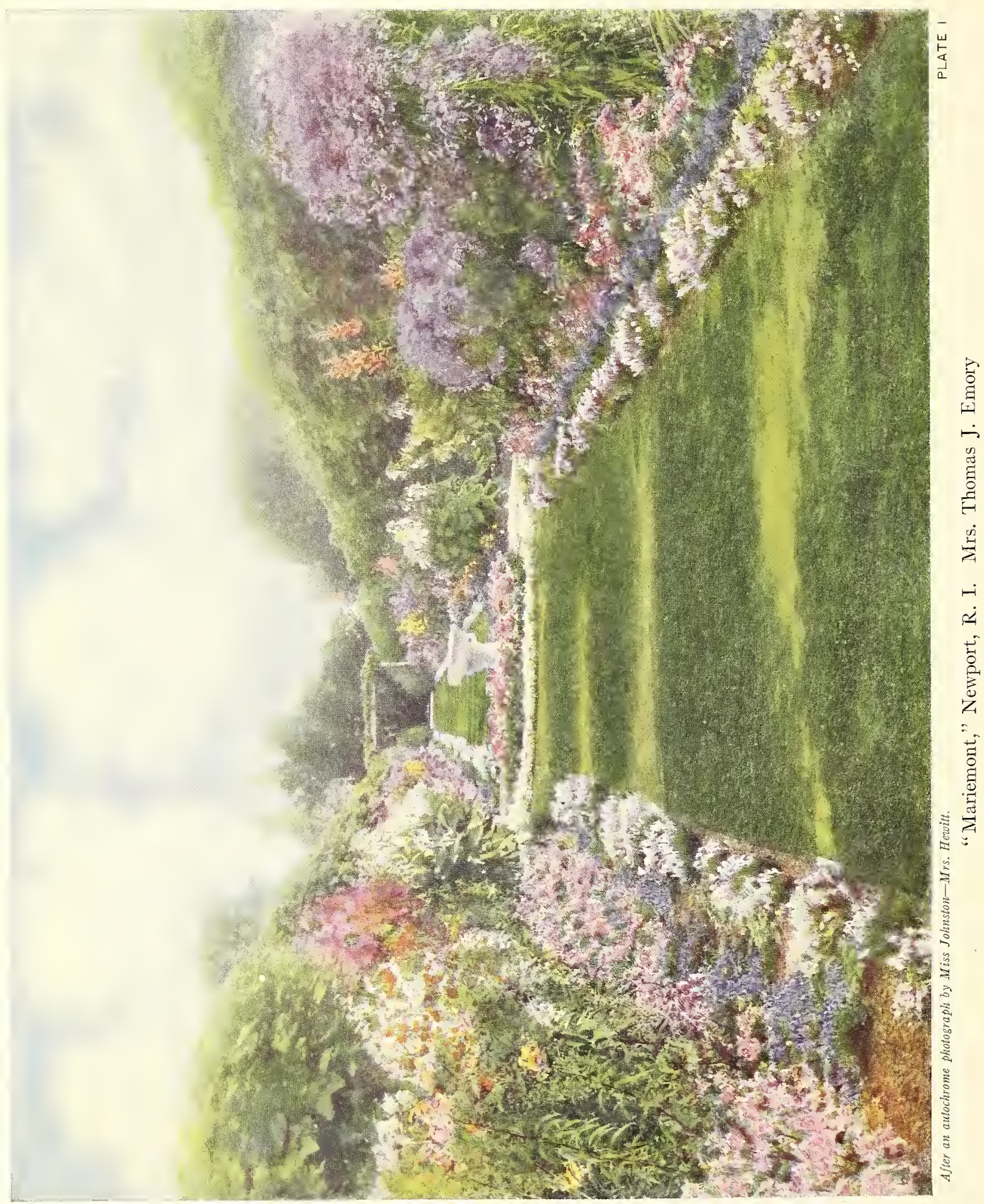




\title{
BEAUTIFUL GARDENS IN AMERICA
}

BY

LOUISE SHELTON

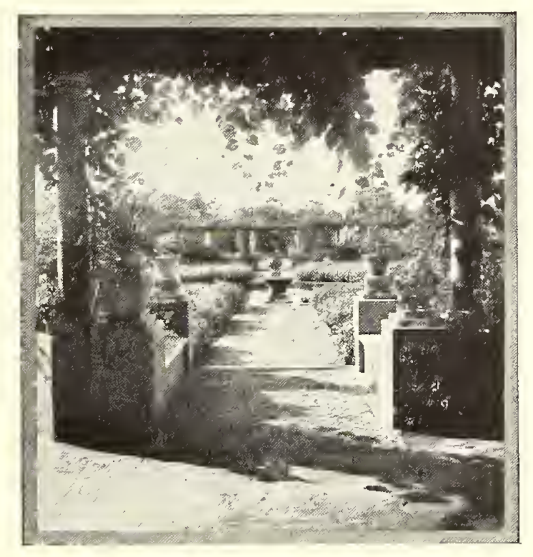

SECOND EDITION

\author{
NEW YORK
}

CHARLES SCRIBNER'S SONS

1916 
COPYRIGHT, $1915, \mathrm{BY}$

CHARLES SCRIBNER'S SONS

Published November, 1915

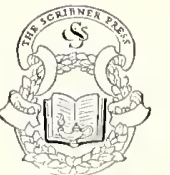


DEDICATED TO THE PRAISE OF THOSE AMERICAN MEN AND WOMEN, OF WHATSOEVER PERIOD, WHO HAVE PLANTED SO BEAUTIFULLY THAT THEIR GARDENS ARE AN INSPIRATION TO OTHERS IN ALL GENERATIONS

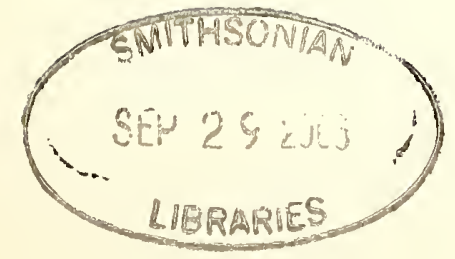




\section{IN GREEN OLD GARDENS}

Here may I live what life I please, Married and buried out of sight, Married to pleasure, and buried to pain, Hidden away amongst scenes like these Under the fans of the chestnut trees: Living my child-life over again, With the further hope of a fuller delight, Blithe as the birds and wise as the bees. In green old gardens hidden away From sight of revel, and sound of strife, Here have I leisure to breathe and move, And do my work in a nobler way;

To sing my songs, and to say my say; To dream my dreams, and to love my love, To hold my faith and to live my life, Making the most of its shadowy day. 


\section{CONTENTS}

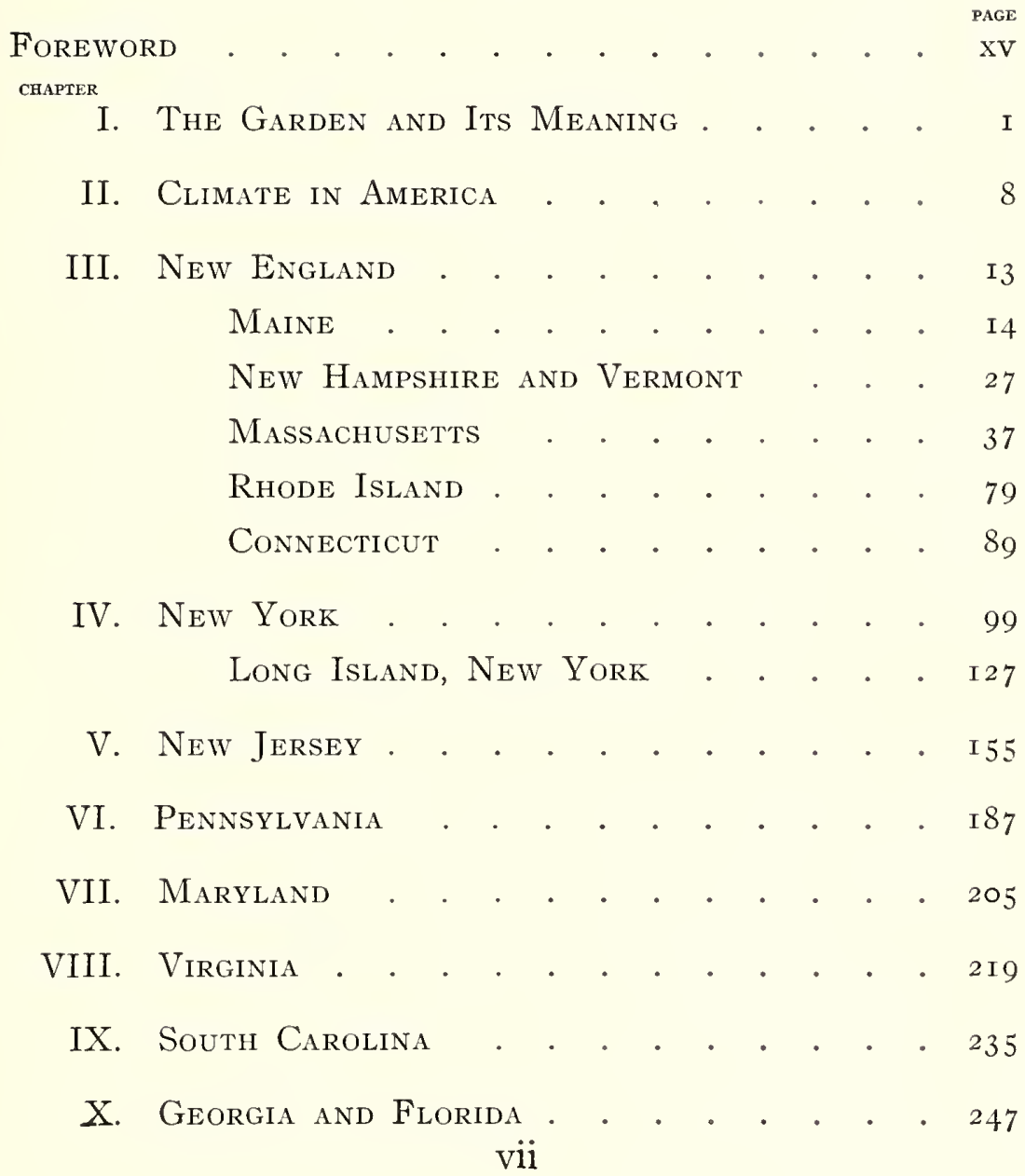




\section{CONTENTS}

CHAPTER

XI. Tennessee and Missouri . . . . . 255

XII. Illinols And Indiana . . . . . . . 265

XIII. Оніо . . . . . . . . . . . . 277

XIV. Michigan and Wisconsin . . . . . 287

XV. New Mexico . . . . . . . . . . 299

XVI. California . . . . . . . . . . 303

XVII. Oregon and Washington . . . . . 323

XVIII. Alaska . . . . . . . . . . 337

XIX. Vancouver Island . . . . . . . 340

A Few Garden Gates. . . . . . . 347 


\section{ILLUSTRATIONS}

\section{COLOR-PLATES}

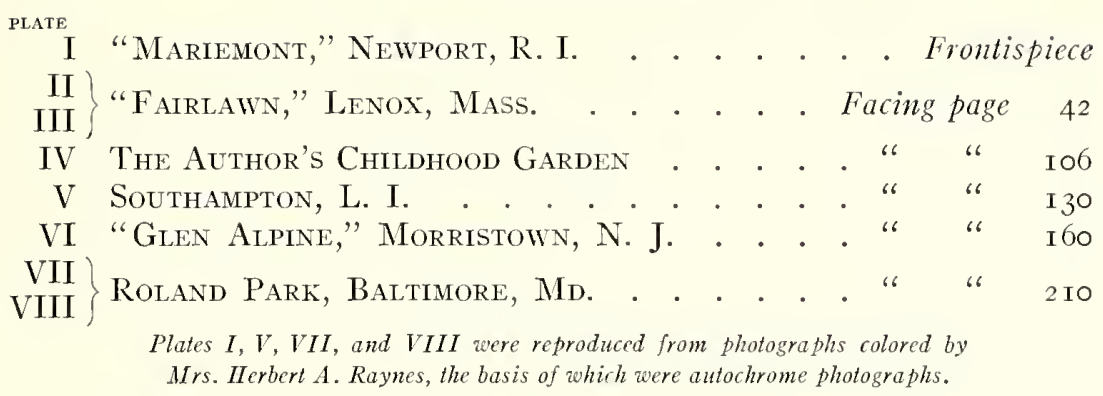

\section{HALF-TONE PLATES}

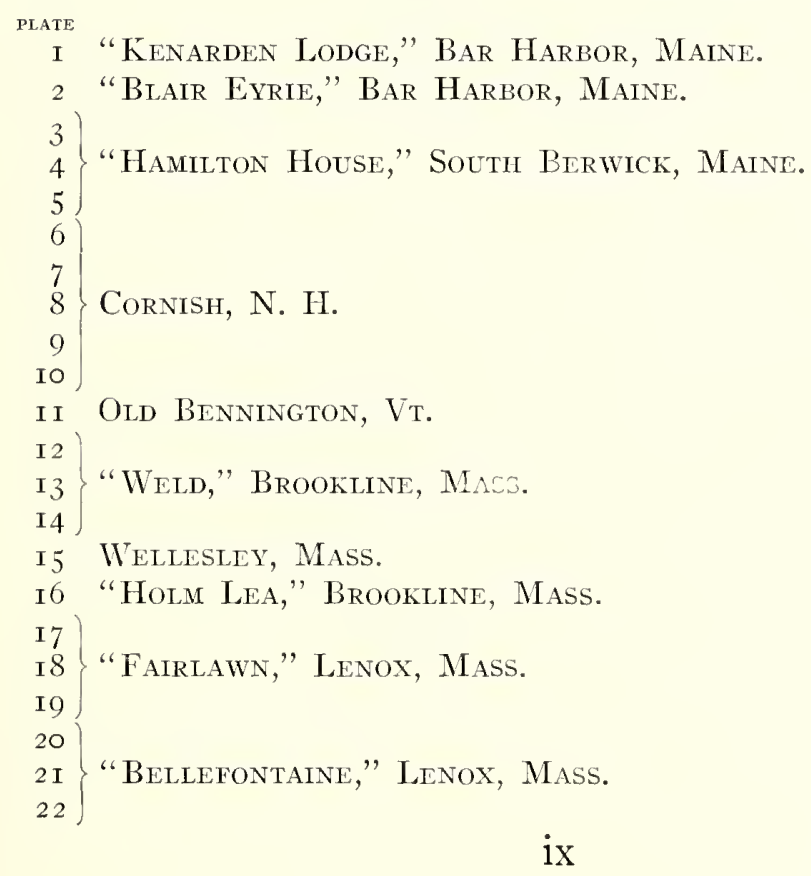




\section{ILLUSTRATIONS}

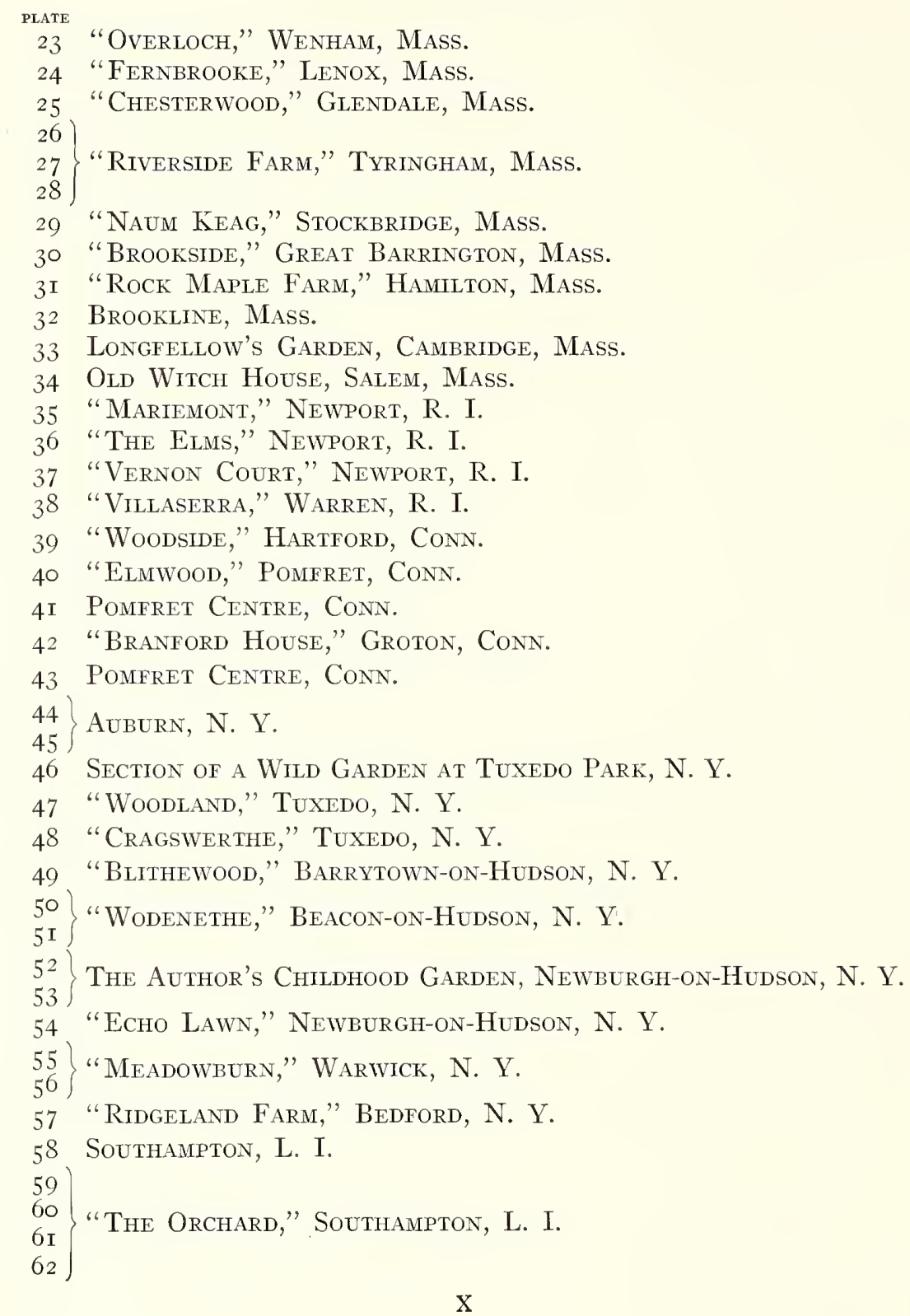




\section{ILLUSTRATIONS}

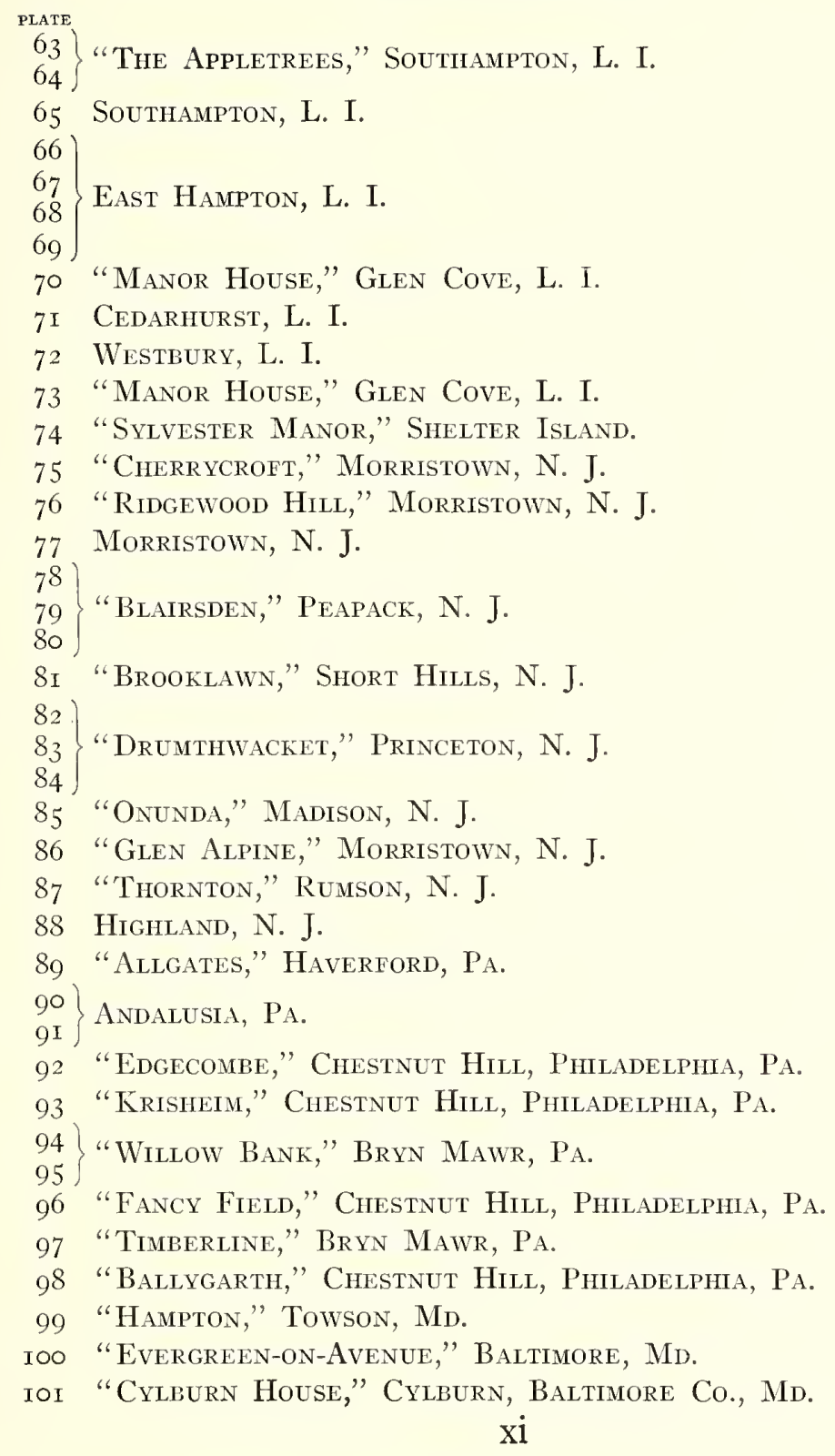




\section{ILLUSTRATIONS}

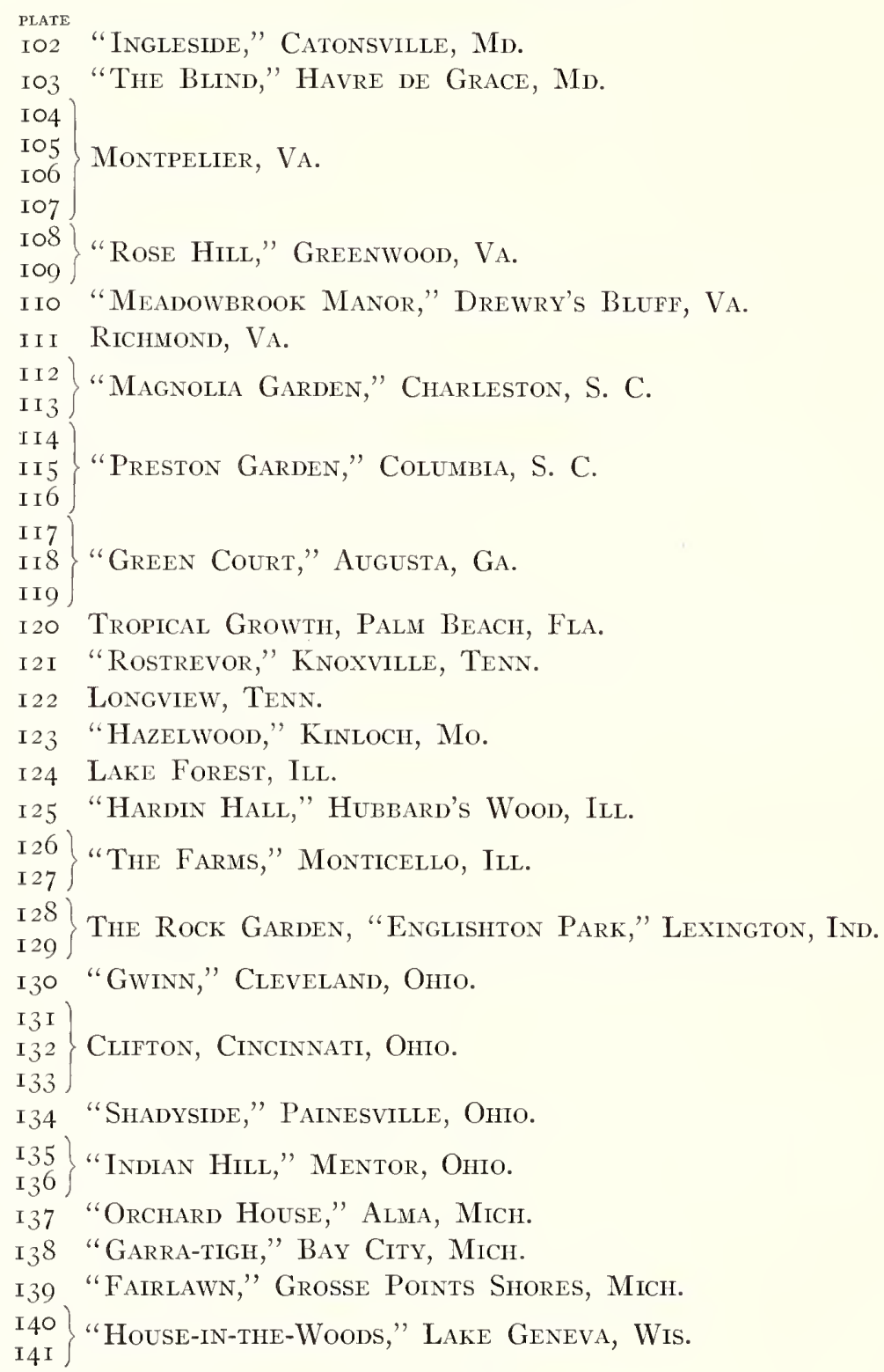




\section{ILLUSTRATIONS}

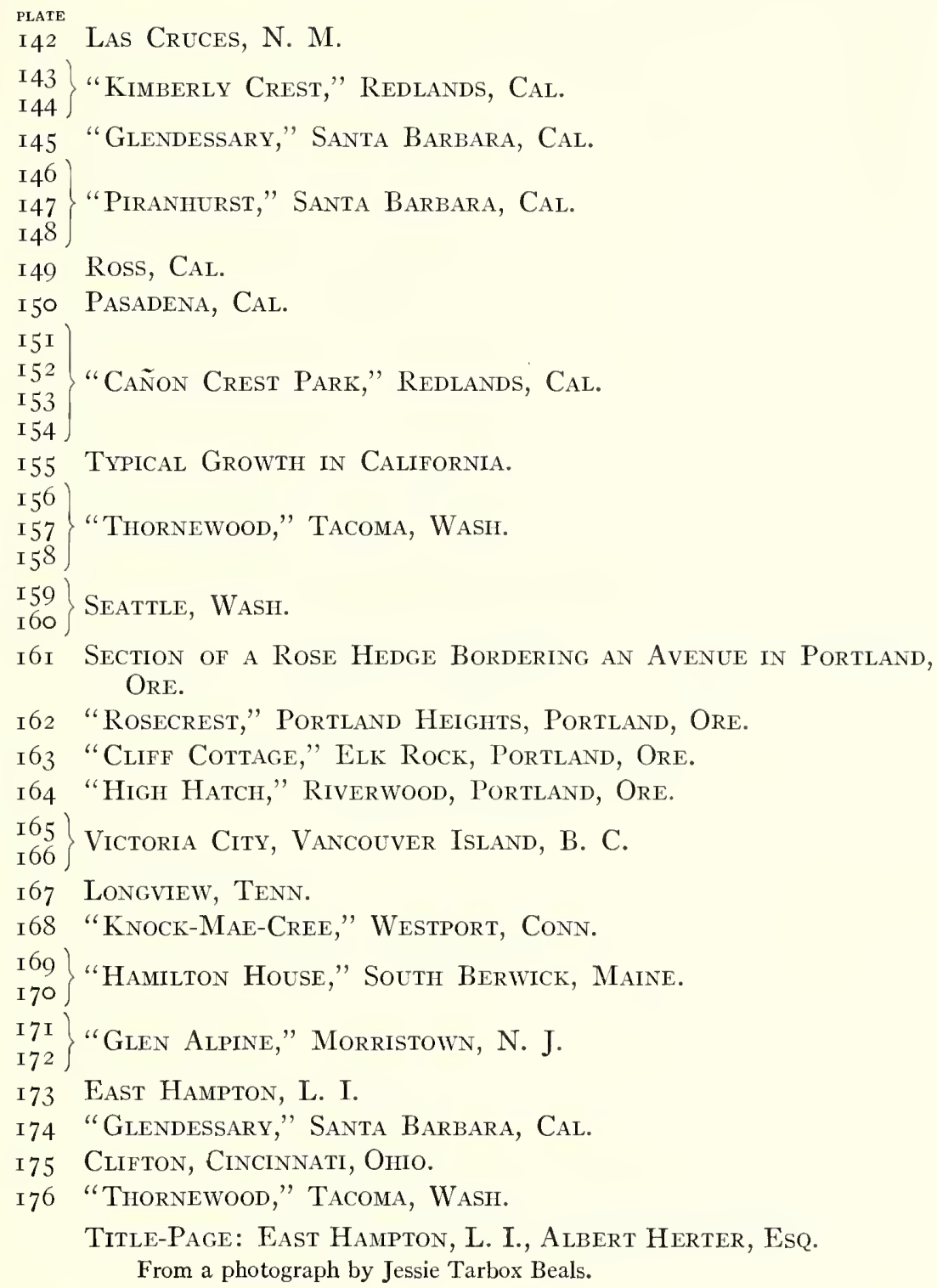




\begin{abstract}
“ GARDEN was wonderful at night-a place of A strange silences and yet stranger sound: trees darkly guarding mysterious paths that ran into caverns of darkness; the scents of flowers rising from damp earth heavy with dew; flowers that were weary with the dust and noise of the day and slept gently, gratefully, with their heads drooping to the soil, their petals closed by the tender hands of the spirits of the garden. The night sounds were strangely musical. Cries that were discordant in the day mingled now with the running of distant water, the last notes of some bird before it slept, the measured harmony of a far-away bell, the gentle rustle of some arrival in the thickets; the voice that could not be heard in the noisy chatter of the day rose softly now in a little song of the night and the dark trees and the silver firelight of the stars."
\end{abstract}

- Hugh Walpole. 


\section{FOREWORD}

Books and magazines written by and for American architects usually show in their illustrations fine imitations of lovely French, English, and Italian formalism and works of art in marble or other stone ornamenting the gardens of great mansions in this country.

The object of this book is to present, more particularly, another type of garden, demonstrating the cultured American's love of beauty expressed through plant life rather than in stone; showing the development of his ideal in more original directions, when planning for himself the garden spot in which he is to live rather than when building wholly in imitation of some accepted type of classic art.

With but few exceptions, these illustrations are of a class which might be called personal gardens. The attractive features in nearly every view speak so eloquently for themselves that there seems but little need of detailed verbal description of each beautiful spot.

In covering all sections of the country, occasion is given for the observation and study of widely varying climatic 


\section{FOREWORD}

conditions, the results of which the author has also sought to consider.

Some difficulty has been felt in properly ascribing the ownership of a number of the gardens illustrated. As a rule, there is but one recognized director of the garden's welfare - rarely are two members of a household equally interested. While he is by custom acknowledged master of the house, it is oftener she who rules supreme among the flowers. Misnaming the real possessor might be a serious mistake; attributing the ownership to two is superfluous; the benefit, where any doubt existed, has been therefore given to the fair sex, with due apology for possible errors.

Morristown, N. J.,

LOUISE SHELTON.

October 28, I9I 5 . 
BEAUTIFUL GARDENS

IN AMERICA 


\section{A GARDEN}

Come not with careless feet

To tread my garden's unfrequented ways.

No highroad this, no busy clanging street,

No place of petty shows and fond displays.

Here there are blossoms sweet

That shrink and pine from inconsiderate gaze;

And here the birds repeat

Only to loving ears their truest lays.

Hither I can retreat

And drink of peace where peace unravished stays.

Herein are streams of sorrow no man knows-

Herein a well of joy inviolate flows;

Come not with careless feet

To soil my garden's sanctuary ways.

-Anonymous. 


\section{BEAUTIFUL GARDENS IN AMERICA}

\section{I \\ THE GARDEN AND ITS MEANING}

A world without flowers! What would it be? Among, those who know, such a question needs no answer - and we are not seeking a reply from the uninitiated who, for lack of understanding and sympathy, can but gaze at us with wondering pity, when our gardens cause us to overlook so much that to them means life. But is there any life more real than the life in the garden for those who actually take part in its creation and nurture it carefully week by week and year by year? If, owing to this absorbing occupation, we fail to give a full share of ourselves to some of the social avocations of the busy world are we to be pitied for getting "back to the soil" to which we belong? Man was put by the Creator "in the Garden of Eden to dress it and to keep it," and even after his forced departure therefrom he was bidden to "till the ground," and the reward seems great to us who know the meaning of the signs and wonders continually being revealed in the garden world. 


\section{BEAUTIFUL GARDENS IN AMERICA}

In seeking the simpler life which many are now craving, if luxuries are blessings that we could do without, must we count the flower garden a luxury? Not while its beauty is a joy in which others may share, nor when it helps to keep at home our interests which make the real home. There is a luxury that often induces the roaming spirit, and doubtless were there fewer motors there would be still more gardens and incidentally more home life. Yet notwithstanding this temptation to roam, gardens are now on the increase in almost every section of the United States. We have made a brave beginning of which to be jistly proud.

If only we could live in the world more as we live in the garden, what joy and contentment would be brought into the daily life! In the garden hurry and noise are needless, for perfect system can prevail where each plant, each labor has its own especial time, and where haste is a stranger, quiet reigns. It is in the stillness of the green world that we hear the sounds that make for peace and growth. In the garden, too, we labor faithfully, as best we know how, in following rules that promise good results. Then at a certain time we must stand aside, consciously trusting to the source of life to do the rest. With hopeful eyes we watch and wait, while the mysterious unseen spirit brings life into plant and tree. When something goes wrong, how sublime is our cheerful garden philosophy, as smiling we say: "Just wait until we try next year!" And patiently we try again, and ever patiently, sometimes again 


\section{BEAUTIFUL GARDENS IN AMERICA}

and yet again. Our unwritten motto is: "If others can, then why not we?" Even the man who "contends that God is not" shows all this wondrous reliance in the unseen force within his garden.

With hands plunged into the cool earth we seem to bury in the magic soil all thoughts that jar till we almost feel ourselves a part of the garden plan; as much in harmony with it as the note of the bird, the soft splash of the fountain, the tints of the flowers and their perfumes. This idea is better expressed in four lines found inscribed on an old garden seat:

"The kiss of the sun for pardon, The song of the birds for mirth, One is nearer God's heart in a garden Than anywhere else on earth."

It is not a selfish life - the object in view is not a narrow one. How few would be content to create a beautiful garden if none could see! And our pleasure is not complete until others have shared its sweetness with us. The gardener is developing nature in the simplest and truest way, following the thought of the first great Architect and gladdening the hearts of men with the vision beautiful of the possibilities within plant life. In the flower garden the efforts are for upbuilding, for giving back some of the beauty intended in the Perfect Plan, too often defaced by man's heedlessness.

Dating back their beginning some two hundred years in 


\section{BEAUTIFUL GARDENS IN AMERICA}

certain Southern States, numerous gardens, beautiful with age, tell the story of the ardent garden lovers of earlier days, who had to send abroad for their green treasures which they planted and carefully tended, hopefully planning for the future. Many such gardens with their choice shrubs and trees still stand as green memorials to those long-ago people who had time and money for this luxury. Since then the hardships following war have brought sad neglect to the beautiful places - the number we can never guess - many of which, however, are now being aroused to fresh life by new owners who appreciate the charm and dignity of an ancient home.

Hidden away in some of the old plantations of the South, and scattered over the Eastern States, near Philadelphia, along the Hudson River, and in parts of Massachusetts, the best of the older gardens are found. Beautiful, too, while often beyond reach of the camera, are many of the more modern creations so skilfully and lovingly fashioned by men and women of later generations. It is impossible to do justice in photography to some of them when certain conditions prevent the camera from being placed at a range favorable to getting a view of the larger portions in one photograph. Sometimes they are composed of three or four connecting sections, each bringing a surprised delight to the visitor passing from one to the other, but such an arrangement cannot be satisfactorily portrayed in a picture.

One strange reason why some American gardens are 


\section{BEAUTIFUL GARDENS IN AMERICA}

not photographed for the public is that occasionally people are found who will not share their blessings with others less fortunate; who jealously keep in seclusion all the wealth of nature's sweetness contained in their garden plot.

After all, is not the delight which belongs to a garden but a bit of borrowed glory from the Creator of sunlight, and of the kingdom of flowers? If a garden is worthy of showing to our intimates, can we close it to the stranger who may need even more to breathe inspiration from its peace and loveliness? The foreign custom of opening the fine places to the public on stated days is one that we should freely emulate. And to those who may not come to the gardens, what a boon is photography, especially in color, placing in our very hands the beauty that we crave!

The views contained within this book show gardens that were planned, with but few exceptions, by their owners, earnestly laboring to express their sense of the beautiful in these their outdoor homes. And so great is the individuality evinced in most of them that there are hardly two gardens that resemble one another; for the differences in gardens are as many as the endless number of varying characters written in the faces of men. Both are stamped with the spirit behind them. In visiting gardens it is not difficult to distinguish between the ones fashioned by "love's labor" and those made by the practical gardener.

More and more we are getting away from the cold, stiff planting of Canna, Coleus, and Salvia. Few of us can 


\section{BEAUTIFUL GARDENS IN AMERICA}

tolerate the impression of newness and rigidity in the garden, and as Father Time cannot help us fast enough we try to emulate him by stamping his mark of mellowness in innumerable ways upon the youthful garden. Then Mother Earth is consulted as to her unrivalled way for the grouping of her flower family, and she shows us the close company they keep - hand in hand over the whole meadow - nothing stands quivering alone, grasses and plants blending to fill all spaces. Then above, in the rainbow, we learn the harmony for our color scheme, and unto no nation on earth need we apply for the latest theories dealing with these subjects for the beautifying of our gardens. The more of the nature scheme we bring into them the greater satisfaction will they give.

We should build the garden with a setting of fine trees grouped upon the outskirts, otherwise it will seem as incomplete as a portrait without a frame. Half of the charm attached to the beautiful old gardens of Europe lies in the richness of their backgrounds of stately hedges and trees.

If comparisons were to be made between such views as those shown in this book and the pictures of English gardens, for instance, the differences would not in every case be favorable to England, although it must be admitted that age has given a dignity and grandeur to many English gardens that could hardly be surpassed. Time, doubtless, will add this dignity to our gardens, but can we not feel that we have already equalled some of the smaller 


\section{BEAUTIFUL GARDENS IN AMERICA}

English gardens when we consider the poetical beauty found in most of these illustrations?

Unfortunately, except in a few localities, our climate does not encourage the perfect development of the choicest of the evergreen hedge-plants, and yet with time we can produce some moderately fine effects in hedges. We may not hope soon to rival the best of the foreign gardens that have been maturing through generations of continuous care. Favored not only by climate but by riches unknown to the early landowners of our States, the best of the old gardens across the sea stand for the combined dreams of the many minds which gradually evolved them, the loving handiwork of innumerable patient toilers who have successively ministered to them.

Just as there are gardens peculiar to other nations, Dutch, French, Italian, etc., might we not give serious consideration to evolving some day a type peculiarly American, inasmuch as it would embody the poetic and artistic sense of our country? Such a result might be attained even should we claim the privilege of our individual liberty, to plant, each one for the expression of his own soul, thus keeping our gardens distinctly variable and original in type, and so ultimately national. 


\section{CLIMATE IN AMERICA}

Few subjects are more bewildering than that of climate in the United States, and its effect on gardens in different sections is an ever interesting study. Replying to the question as to which locality in the East might be said to have the longest continued flowering period, an expert in the Agricultural Department writes: "The question of plant life in relation to climate is a very large one and one about which it is hard to generalize without close study in the various parts of the country. Some little work along these lines is being attempted, but as yet we have been unable to make any report upon it."

Correspondence with gardeners in the various States has furnished the brief data given in connection with the following chapters, showing that the local conditions as affecting garden culture are much more encouraging in some places than in others.

Not only are there the matters of latitude and altitude to be considered, but often quite as important is the influence of the Gulf Stream in the Atlantic or of the Japan Current in the Pacific Ocean. Again, there is the moist climate by the sea, or the quality of soil, the periodic tor- 


\section{BEAUTIFUL GARDENS IN AMERICA}

rential rainfall of one section, and elsewhere the long months of drought.

Generally speaking, our country is, in most parts, a land of sunshine, with usually sufficient rain and moisture to benefit plant life, and while we grumble at our sudden changes in temperature, how few of us realize the blessing of an abundant sunshine pervading the "great outdoors" and incidentally the gardens!

Nowhere do flowers grow more luxuriantly, in greater variety, or through a season more prolonged than on the coasts of Oregon, Washington, and California,- -soil, moisture, and temperature combining to make gardening a simpler task than it is elsewhere. The shore country of Southern California is a perpetual garden, with a climate almost unrivalled for plants and for humans. North of San Francisco the near approach of the Japan Current produces a climate quite similar to that of England, and with the exception of possibly two months (and even then an occasional Rose may bloom) flowers are found all the year round. This favored section of the Northwest nevertheless is not visited with as much sunshine as is found elsewhere, but its gardens blossom with little assistance save from the frequent rainfall, more welcome to plants than to men.

In Kansas and the other flat and fertile States of the Middle West the garden period, on account of the long, dry summers, is usually limited to the weeks from late March to late June. In the more northern temperature 


\section{BEAUTIFUL GARDENS IN AMERICA}

of the lake region gardens which flourish all summer are numerous.

The Atlantic States have a shorter blooming season than those on the Pacific coast. Throughout the South, east of New Mexico, the warm weather season is as prolonged as on the Pacific coast, and yet in the Southern States garden bloom is checked half-way through the summer by excessive heat and drought (except in the favored mountainous localities), which at least interrupt the continuous succession of flowers. For this reason gardening in the South except in spring, or in high altitudes, is generally discouraged.

Although not stated as an indisputable fact, scientifically, we are inclined to believe that the seacoast section of the Maryland peninsula is the locality in the East especially favorable to the most prolonged season of bloom. Lying between sea and bay, this particular district in the latitude for early spring and late frost enjoys also the benefit of surrounding waters, escaping thereby the parching summer climate from which gardens of the interior suffer, to the west and south and to the north, almost as far as Philadelphia.

In Maine conditions are different; April and May gardens are conspicuously absent. The flower season generally begins in mid-June and does not much exceed three months, but in that period the bloom is exceptionally luxuriant. The season is necessarily a short one, as it is throughout this latitude westward to Oregon, where after 


\section{BEAUTIFUL GARDENS IN AMERICA}

reaching the Coast or Cascade Range there is a change and the climate becomes more like that of England than Maine. Along the Atlantic coast from Maine to New Jersey, where the climate is ideal for flowers, the greatest proportion of Eastern gardens may be found, on the shore and inland as well.

So much for the general climatic effects upon flowers of the more populous districts of our vast country. A few lines will suffice to treat the climate question in connection with hedge-plants.

While the summer climate in the Southern States has not generally a salutary effect upon the flowers, yet it has favored the best development of Boxwood, Holly, and certain other choice shrubs and trees, which do not thrive well north of Philadelphia. Fine specimens of Boxwood are rare sights in New England, where the more severe winters have from time to time destroyed the top growth. Many old New England gardens show the characteristic Box-edged path, but the shrub is usually not over two feet high, and is likely to remain so unless eventually the winter climate should moderate. Boxwood is seen on the Pacific coast, north of San Francisco, but not to the south, where Cypress is popular. There is little Boxwood in the latitude of New York City, except for edgings, where for tall hedges Privet, Arbor-Vitæ, Hemlock, and Spruce are probaby the most reliable evergreens. Arbor-Vitæ is unlikely to live longer than seventy years.

Although all of our States are not represented in this 


\section{BEAUTIFUL GARDENS IN AMERICA}

volume, these views are taken so generally from almost every section that the climatic conditions describing one State may usually stand as well at least for the States immediately adjoining. The only section of the Union omitted is that part through which run the Rocky Mountains. As a rule, this part of the country is not in its nature open to the cultivation of formal gardens, although its wild flora is remarkable enough to deserve special treatment.

In the brief chapters to follow there will be given more detail relating to climate, in order that we fellow gardeners in all parts of the Union may know something more about one another's garden program, our several problems, and our privileges in this outdoor life that we lead. 


\section{III}

\section{NEW ENGLAND}

With dreams of the English gardens ever before them, our Pilgrim fathers and mothers brought flower and vegetable seeds to the new land, and the earliest entries in old Plymouth records contain mention of "garden plotes."* John Josseiyn, fifty years later, wrote a book called "New England Rarities Discovered," including a list of plants originally brought from old England, mentioning those suitable or not for this climate, and showing that our ancestors had lost no time in planting not only vegetables for the benefit of their bodies but flowers as well for the cheer of their souls.

The New England States naturally have the largest representation in this book, owing to the fact that the climate of numerous Western and Southern States causes many of the inhabitants to find summer homes near the North Atlantic seaboard. It is not that the New Englander is a more ardent gardener, but rather that ardent gardeners from elsewhere are tempted by the soil and climate to join the Easterners in creating these flower "plotes," which beautify hundreds of hamlets in this sec-

*Quoted from "Old Time Gardens," by Alice Morse Earle. 


\section{BEAU'TIFUL GARDENS IN AMERICA}

tion. On the coast particularly flowers grow most luxuriantly, even within a few hundred yards of the surf, where snug gardens protected by windbreak hedges blossom as serenely as in an inland meadow. Not long ago most people believed that gardening or gardens near the sea were an impossibility; but when they realized the hardiness of certain dense shrubs that make perfect hedges and windbreaks, gardens on the shore sprang rapidly into existence, and we of the inland are apt to envy nature's partiality to seaside flowers.

\section{MAINE}

At Bar Harbor on the island of Mount Desert, Maine, as in other places of this latitude, the season, of course, begins later and ends sooner than near New York City. The flowering period is from five to six weeks shorter at Bar Harbor. However, the wonderful summer climate somewhat atones for this briefer season, and the gardens of Maine can boast of unusual luxuriance, in richness of color and size of plants, with but little heat or prolonged drought to affect their best development. The hardier seeds sown in the open will germinate in mid-May; tender annuals in June; the plants of tender annuals go out soon after June 10. Daffodils appear about May 15, followed by late Tulips; German Iris appears in the week of June 10; Sweet William and Roses in early July; Delphinium in mid-July, and Hollyhocks about July 28. Late Phlox is at its best by mid-August. 


\section{BEAUTIFUL GARDENS IN AMERICA}

Thus the plants beginning to bloom near New York City in May and early June do not, on account of the colder spring, appear at Bar Harbor for several weeks to come, when they unite their bloom with the flowers of a later period. The slow-coming spring retards earlier bloom, but has less effect on that of midsummer. The summer residents owning gardens in Maine rarely arrive much before the last of June, and consequently such early bloomers as Tulips, etc., are not seen as often as in the milder climates. In this northern State frost usually destroys the garden by September 15 .

Not only is it possible to grow all the favorite flowers along the shore, but even on the islands lying off the coast of Maine there are innumerable little gardens, such as those at Isleborough, which revel in the moist sea climate of midsummer and blossom most satisfactorily until frost. At this point it is interesting to contrast the climate of the North Atlantic section with the region directly across the continent along the Pacific coast, where at Vancouver's Island, for instance, plant life enjoys a climate similar to that of England, with a growing season quite as prolonged.

There are beautiful gardens at Bar Harbor, on the estates along the shore as well as farther inland. Most of them, screened by fine growths of trees and shrubbery from view of the highway, are equally well protected from sea-winds, blooming luxuriantly in spite of the fact that not very long ago the best authorities believed that gar- 


\section{BEAUTIFUL GARDENS IN AMERICA}

dens on this shore could never prosper. Two of the most noted at Mount Desert are shown in the following pages.

At Kenarden Lodge the garden in the clear atmosphere of this northern climate is most beautiful in form and coloring, and its background of distant hills combines to intensify the charm of this famous place, which is in bloom all summer. The centre beds are filled with annuals in prevailing colors of pink, blue, and white, noticeably Snapdragon, Ageratum, Sweet Alyssum, pink Geranium, and Begonia. Planted in masses, these and other dependable annuals blossom as long as needed. The broad green sod paths act as a setting to the delicate hues covering the beds. The perennials are banked against the vine-covered walls.

The Blair Eyrie garden on the High Brook Road is equally inviting and contains many other attractive features beyond the limits of this restricted view. Peacefully retired behind its boundaries of trimmed hedge and dense woodland, it must always delight the flower lover. Perennials abound with a good supply of enlivening annuals. Its surroundings of evergreen trees are in strong contrast to the brilliant tones of Phlox, Lilies, Hydrangeas, and Hollyhocks, and this garden as seen from an upper terrace is a blaze of lovely color framed in green.

In southern Maine the garden at Hamilton House has no rival in that section of New England. The hand of an artist has wrought a perfect scheme delightfully in accord with an ideal environment; but pictures cannot do 


\section{BEAUTIFUL GARDENS IN AMERICA}

it justice. Within the grassy court of the main garden the several small open beds are filled with groups of annuals. The rear beds contain tall-growing perennials mixed with some annuals. There are weeks when the garden is all pink, and again all blue and white. It is surrounded on three sides with most artistic pergolas, from one side of which the view down the Piscataqua River is a picturesque feature. Stone steps on another side lead to an upper garden filled with bloom surrounding a quaint and ancient little building kept as a studio. In isolation, simplicity, and ripeness the atmosphere of the whole place breathes of olden days, and might well be taken as a model for a perfect American garden. Its gates may be seen in a later section. 


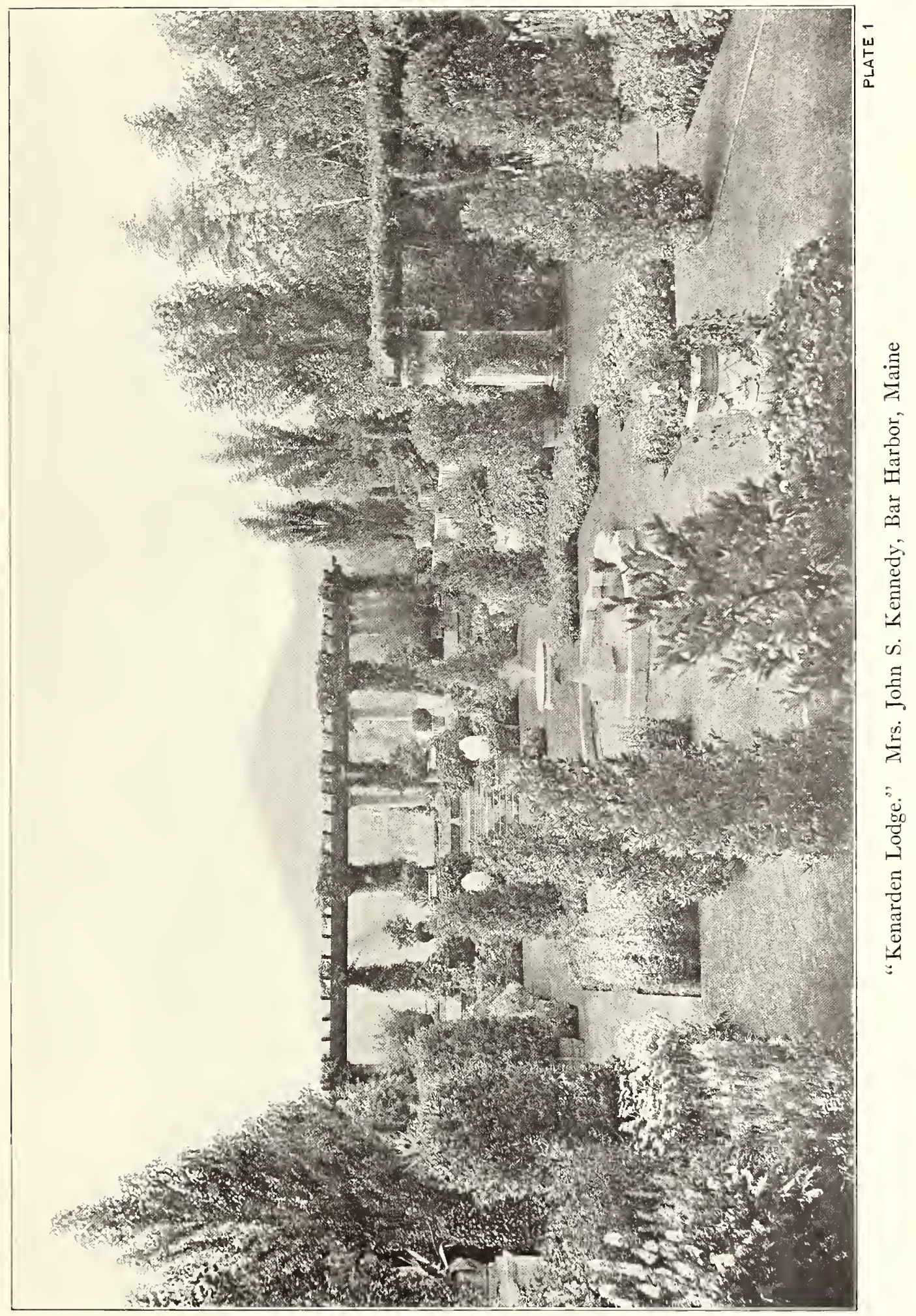





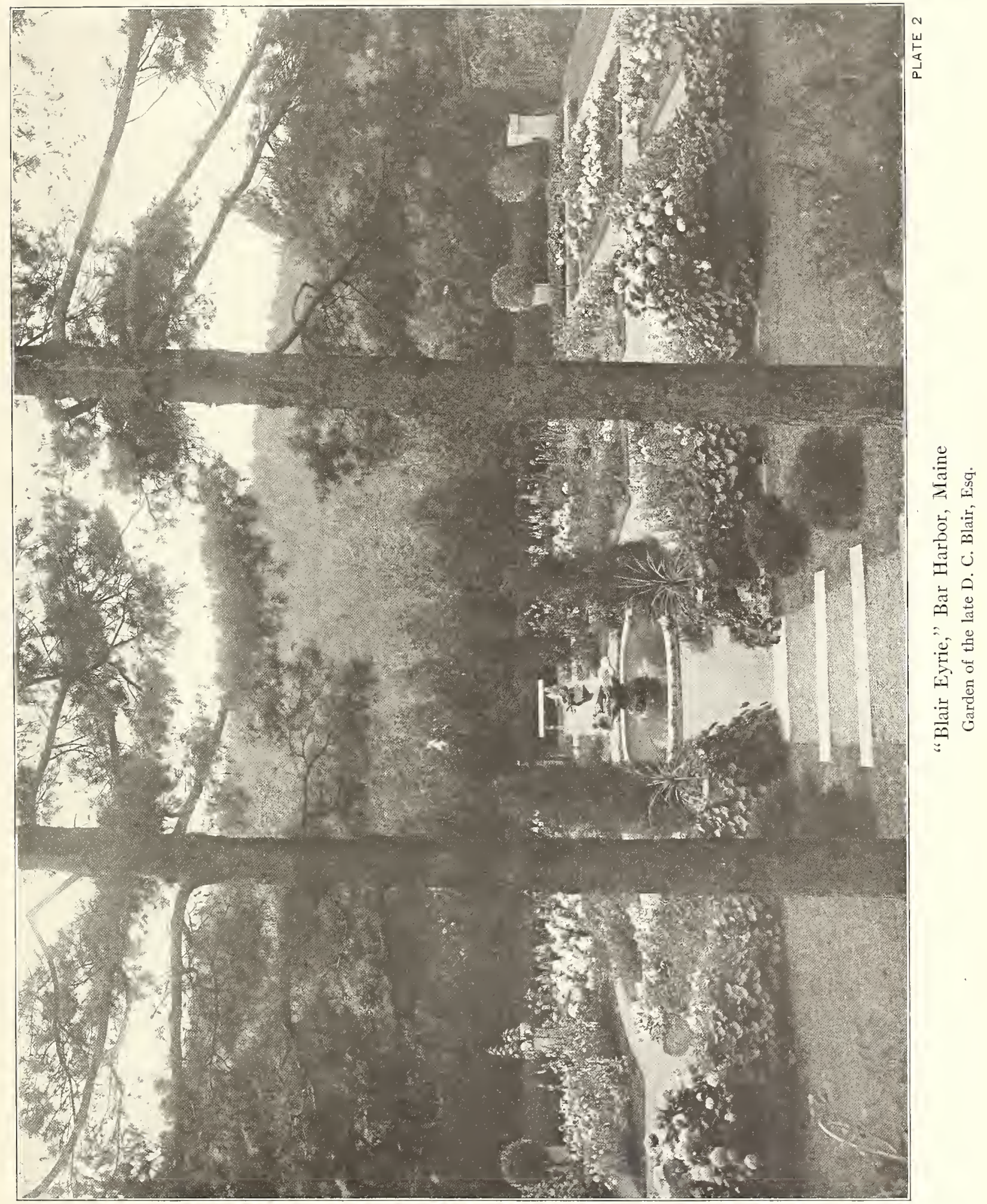





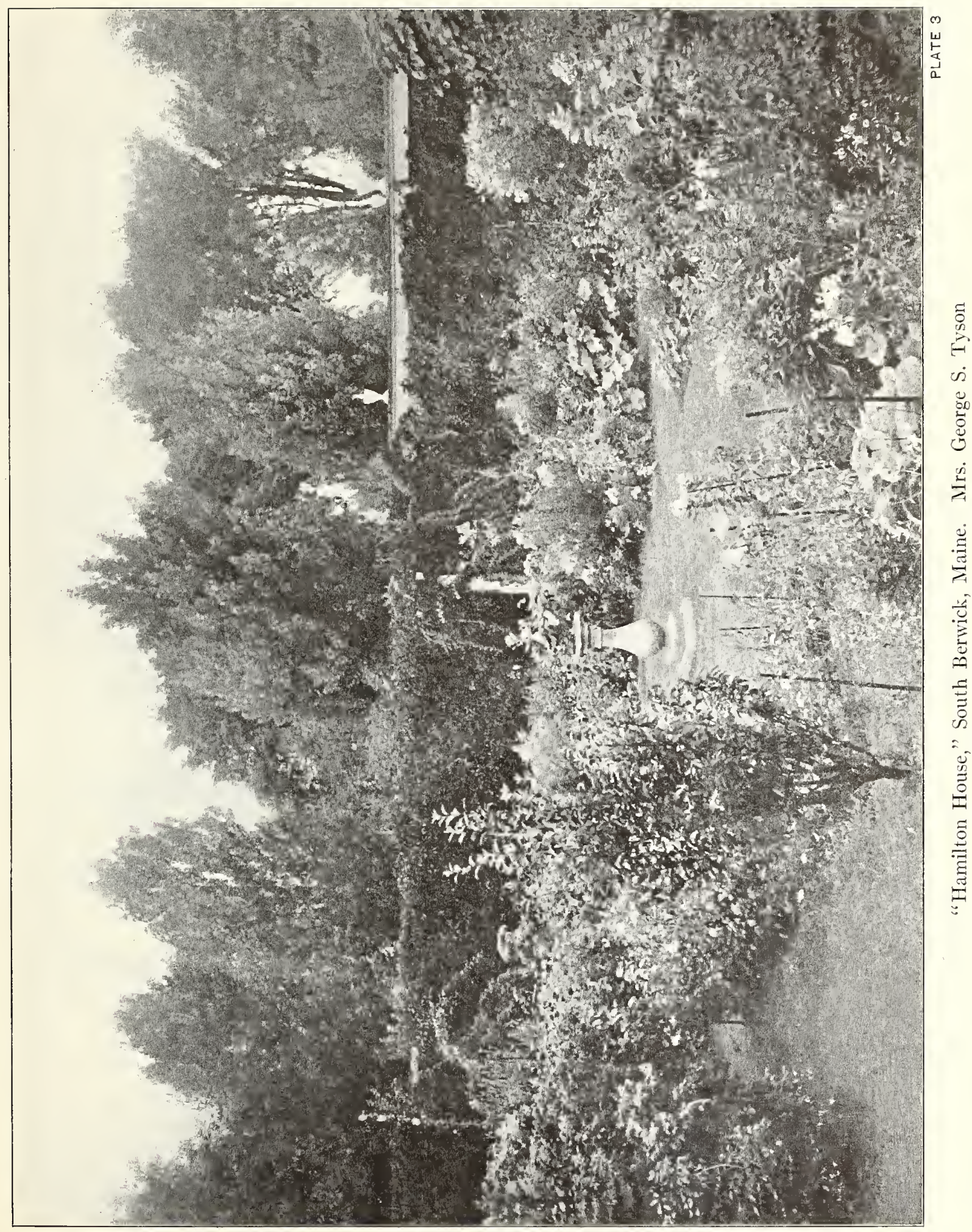





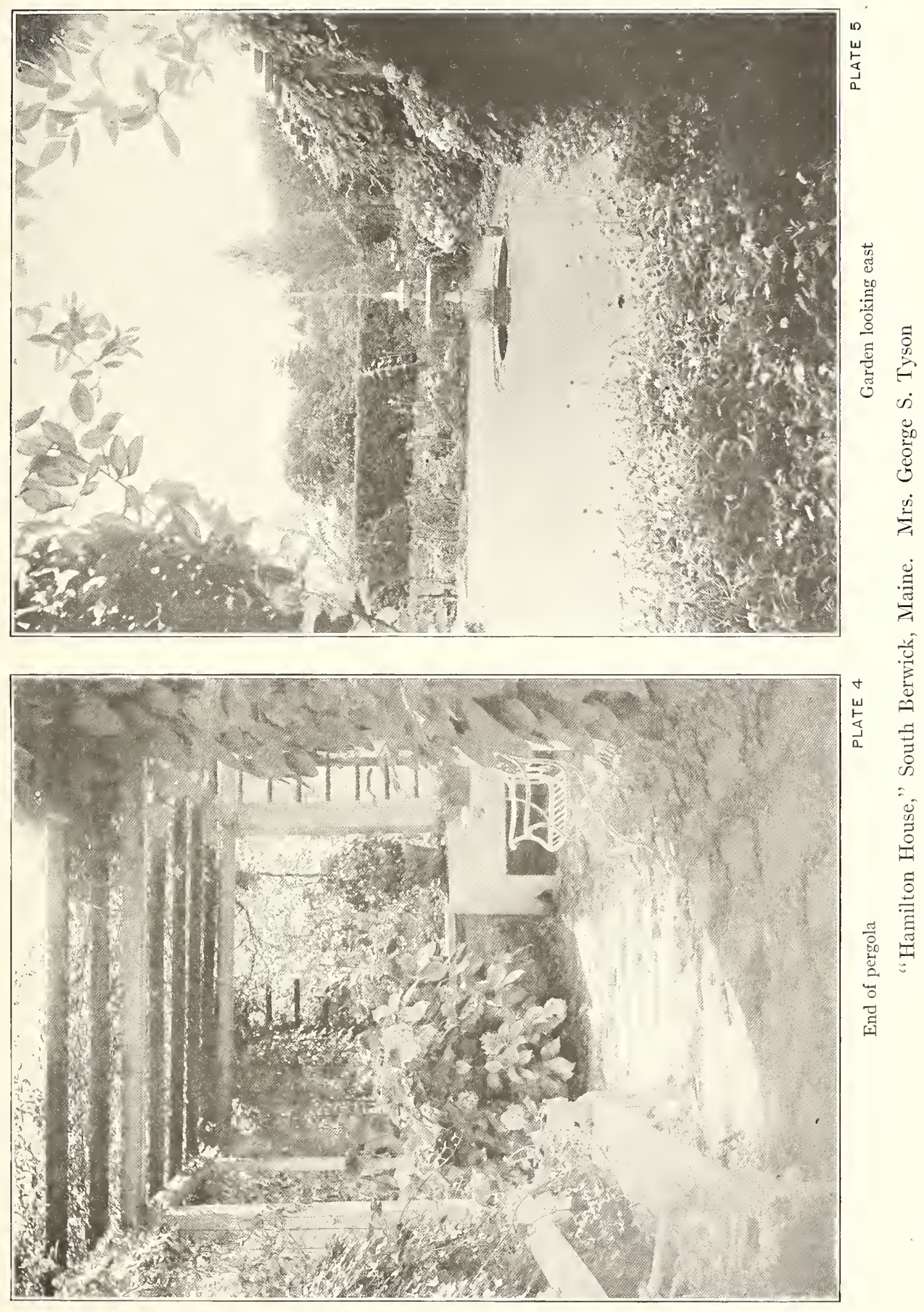





\section{NEW HAMPSHIRE AND VERMONT}

Side by side, these twin States have much in commonclimate, mountains, and old historical associations included. Owing to the short, cool summers of this latitude and altitude, there may be less attention given to flowers than in other parts of New England. But the few illustrations in the following pages are fine evidences of garden art, at least in the region of Cornish, the abode of artists, and where gardens are plentiful. The season opens about four weeks later than near New York City, and in early September frost lays waste the splendid bloom while still in its prime. Although flowers are slow in appearing, a perfection of growth later makes up for lost time. In fact, climatic conditions are so favorable to summer plants that, once started, the garden tasks are lighter than in warmer climates, where drought and pests are more prevalent.

Possibly the most famous of Cornish gardens is that of Charles A. Platt, Esq., whose beautiful gardens in several States are numerous and noted. His own hillside place is a labyrinth of flowers, admirably suiting the environment, spacious and dignified in its rich simplicity.

Perfectly in accord also with the atmosphere of this mountain country is the lovely garden of Stephen Parrish, Esq., delightfully unique and suggesting a little English garden. This enclosure of flowers is but a section of a broader plan where pool, grass, and trees are pleasant factors. 


\section{BEAUTIFUL GARDENS IN AMERICA}

Mrs. Hyde's garden is a mass of bloom composed chiefly of the longest-lived annuals and giving a charming color effect to this picturesque spot.

The best gardens of Vermont, with its still greater area of uplands, are probably those in and around Manchester and Bennington. They are usually of the simplest character, and lovely under the personal care of devoted owners. One worthy of special attention is seen in the view of Longmeadow garden, which is an example of the great value of trees as a background, and a strong argument in their behalf. As a gem needs a setting, so the flowers, in even the most modest planting, are doubly fair when framed in luxuriant green. 


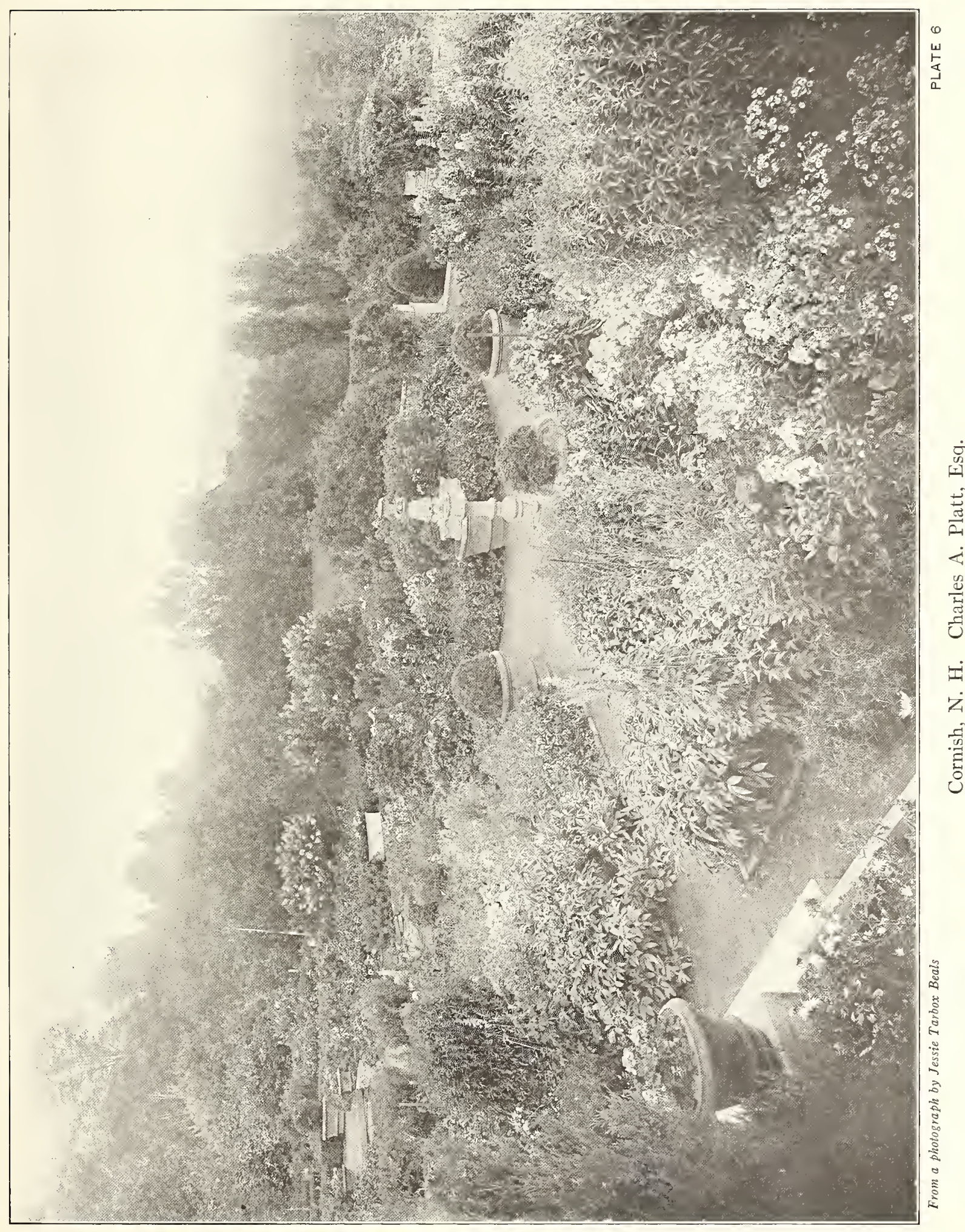





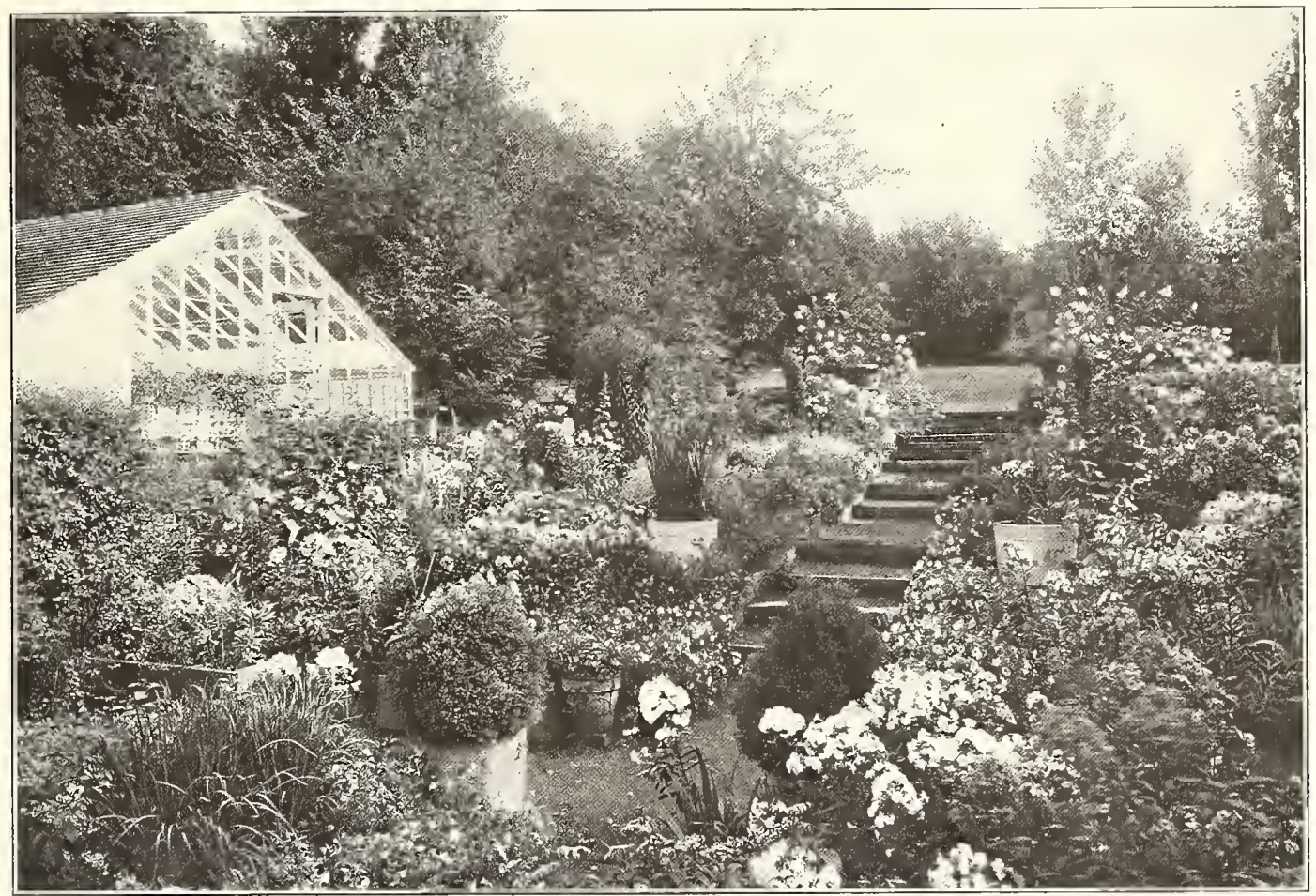

PLATE 7

Cornish, N. H. Charles A. Platt, Esq.

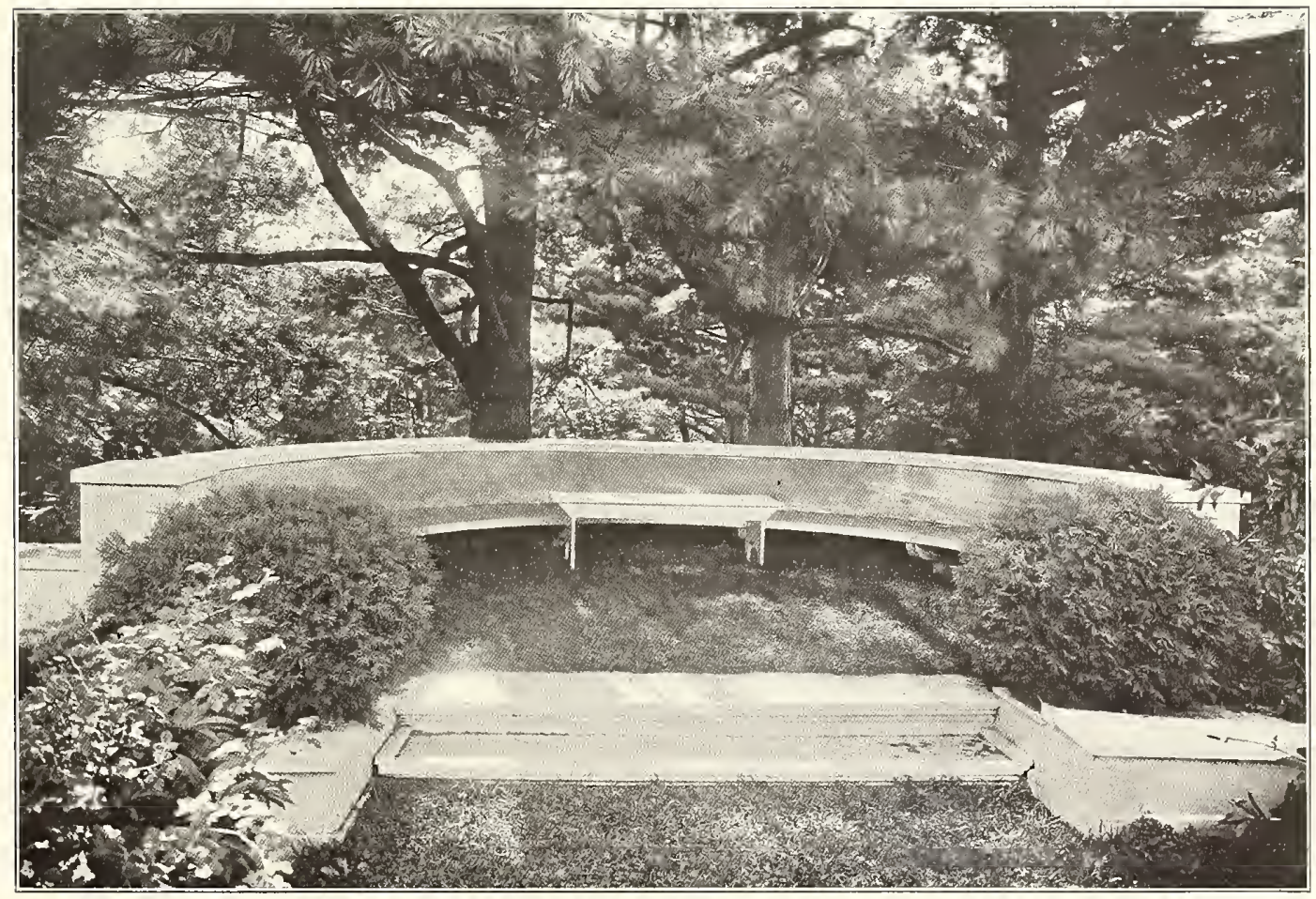

From photographs by Jessie Tarbox Beals

PLATE 8

Cornish, N. H. Mrs. George Rublee 



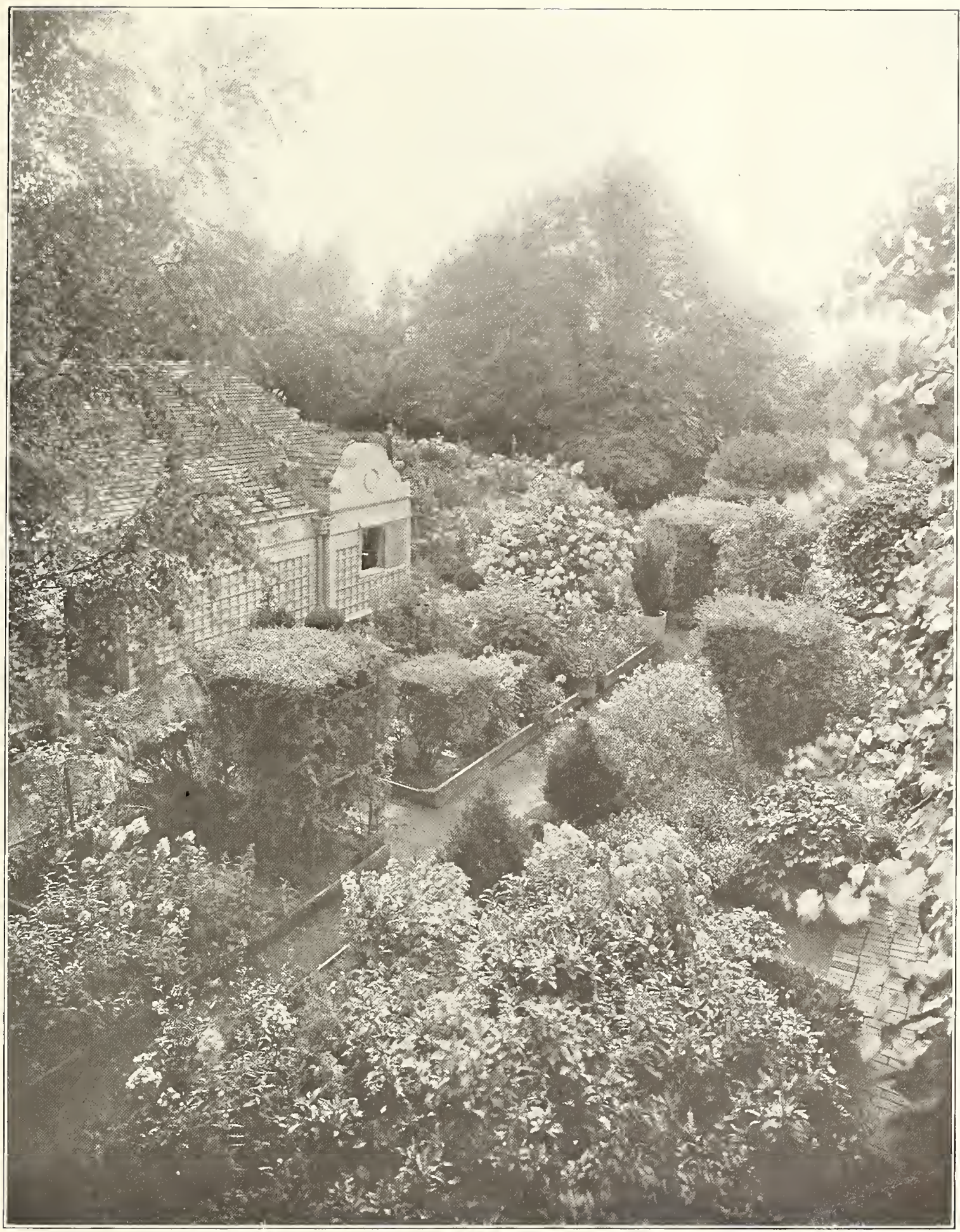

From a photograph by Jessie Tarbox Beals Cornish, N. H. Stephen Parrish, Esq.

PLATE 9 



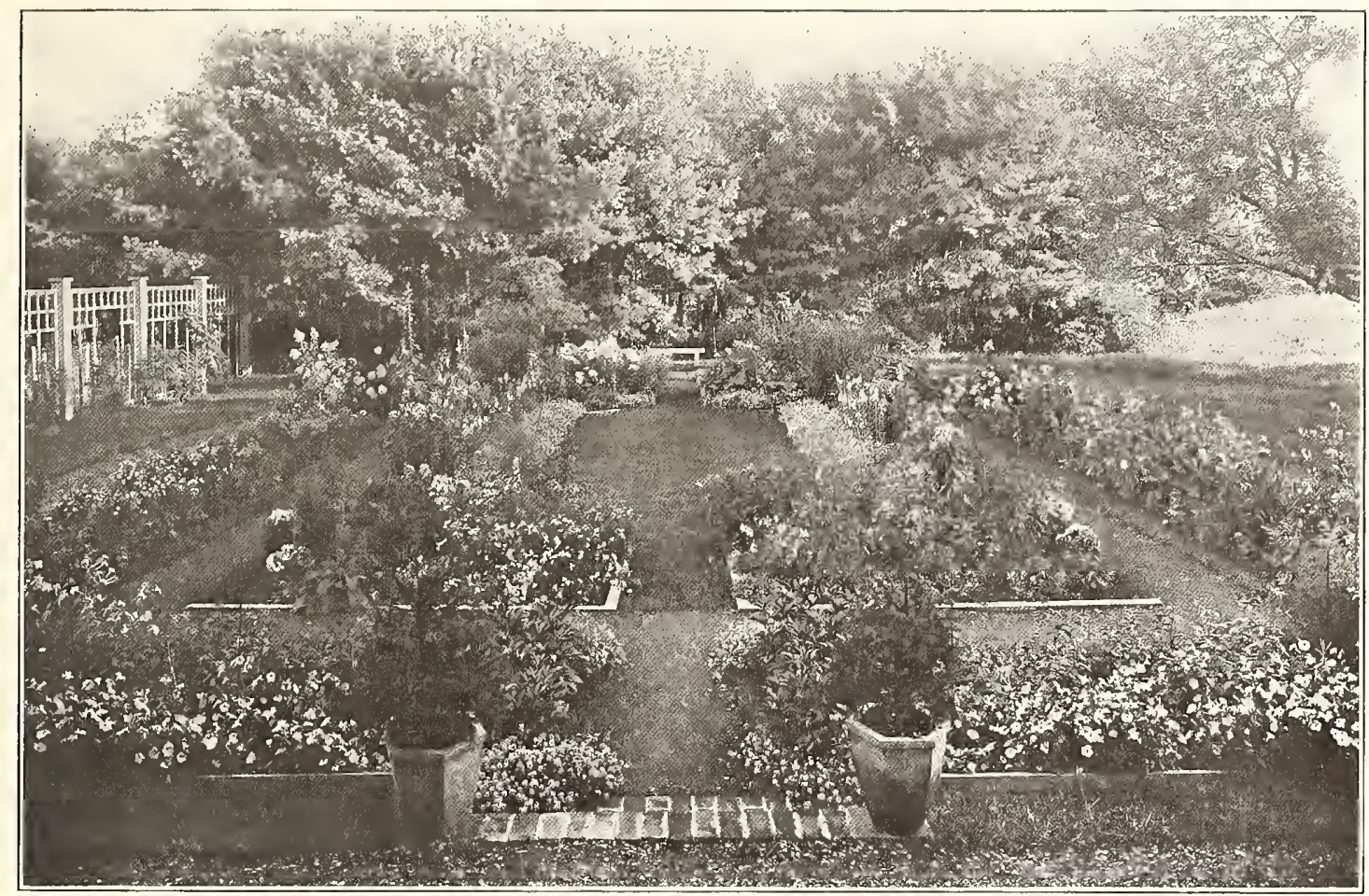

From a pholograph by Jessie Tarbox Bca's

PLATE 10

Cornish, N. H. Mrs. William H. Hyde

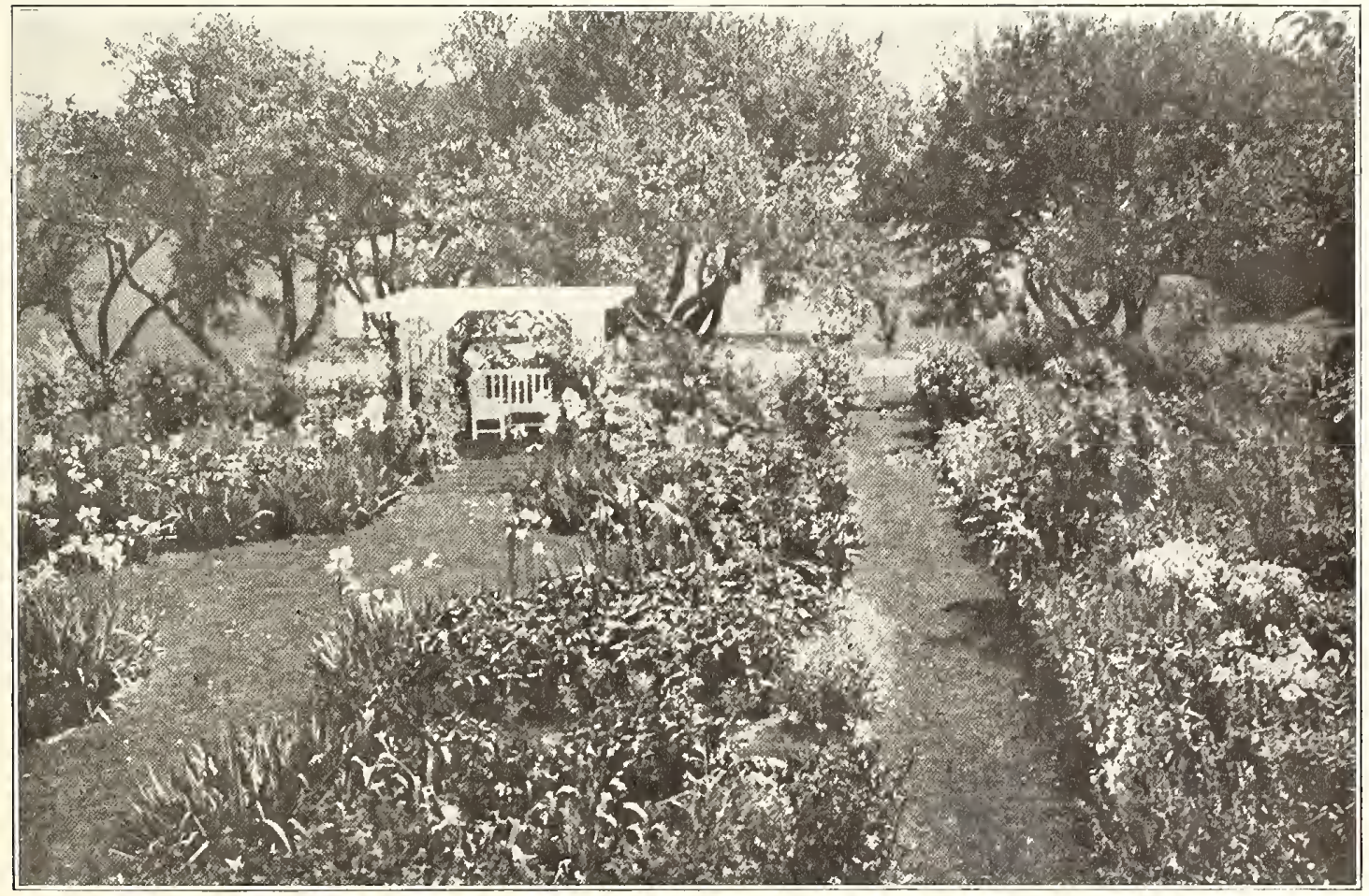

Old Bennington, Vt. Mrs. James A. Eddy

PLATE 11 



\section{MASSACHUSETTS}

Probably no other section of the Union contains as many gardens, old and new, as does this fertile State, combining the advantages natural to the altitude of the beautiful Berkshires with the favorable climate of the coast. People representing nearly every State help to form the summer colonies of New England, more especially in Massachusetts. Everywhere the luxuriance of bloom is very marked and most noticeable on the coast, where all plants, especially certain less long-lived annuals like Poppies, Salpiglossis, and Mallows, reach their limit of perfection and continue at their best for an unusual period. In the latitude of Boston the season starts two weeks later than near New York City, and the gardens, beginning in the German Iris period, open about the fifth of June. The Sweet William and its contemporaries follow by late June; the Delphinium period is early July; Hollyhocks come about July 20. Tender annuals can be safely planted out soon after June 1.

The garden season in the hill country opens a few days later than at Boston, and in the Berkshires the frost is apt to destroy the garden before September 20 . Where the thermometer may drop occasionally to twenty degrees below zero, ample winter covering is necessary, and snow adds its still better protection to the plants during most of the winter months. The average summer heat is not excessive and, although droughts must some- 


\section{BEAUTIFUL GARDENS IN AMERICA}

times be reckoned with, the water supply is generally sufficient.

It would be a serious matter to attempt to name the best gardens in this State, for who could judge where such an infinite variety exists? At least some of the best examples in photography can be given, although each view but hints at the fuller beauty to be found in the garden itself.

Of the many wonderful gardens in Massachusetts possibly the most remarkable of all is Weld, in Brookline, which is known to gardeners far and wide. There is nothing in America more extensive and more richly planted. The numerous beds are filled with bloom for many weeks, and each bed contains a massing of one variety, whether perennials or annuals, which, when it has finished flowering, is replaced by something of another period. The French features in the garden are prominent and the planting may be considered American in some respects - altogether a most pleasant combination.

Of a distinctly opposite type but equally delightful is Holm Lea, near Brookline, and a score of photographs would be necessary to depict this place of flowering shrubs and perennial bloom bordering the winding grass paths leading from one lovely spot to another.

An extremely interesting and unusual type in America is the stately green garden at Wellesley, at this time without a rival in its particular style of planting. Because of its frequent appearance in various magazines 


\section{BEAUTIFUL GARDENS IN AMERICA}

of the country it is too well known to need further description.

Of still another class and very beautiful is one of the most noted gardens in the Berkshires planned entirely by the owner of Fairlawn, Lenox. It is a series of formal gardens, in coloring and setting most perfectly devised. But how useless a photographic description when applied to a combination of gardens spread over one or two acres! Several pools and many old shade-trees play an important part, and its charm is still more enhanced by the wide view of the distant hills fitting so perfectly into the garden scheme.

Three fine illustrations of Bellefontaine but feebly suggest the beauty of a place made of splendid gardens, pools, and temple, long shaded grass walks lined with statuary and other features of Roman art, blending with the natural attractions of this estate. Gardens, lawns, and ponds have the rich woodlands as background, the hedges and shrubs are developed maturely, and everywhere there are charming effects in "green life." Most of this work, it is interesting to add, has been accomplished under the direction of the owner.

Picturesque indeed are other Lenox gardens, including White Lodge. The latter place is noted for its little white garden enclosed in a tall green hedge, and the main garden, especially in June and August, contains a delicious color scheme. Broad grass steps are another feature of the place. Views were not obtainable in time for this volume. 


\section{BEAUTIFUL GARDENS IN AMERICA}

At Fernbrooke is found the garden of an artist and sculptor, a study in color and in garden design most artistically planned, but rambling enough to prevent a connected view in photography. Golden Italian gourds pendent from the pergolas; standard currant bushes bordering a path and covered with red berries as late as September; dwarf fruit trees too, used decoratively, are among the happy points of interest.

The scheme of the garden of a famous sculptor at Chesterwood, in Glendale, is not as dependent on flowers as on the well-considered adjustment of garden equipment to the natural beauty of the environment. Sunshine mingling with the shadows of the spreading trees plays its part by giving life and color in changeful tones to the old stone seat and fountain. The vine-covered arch frames a view of the flower-bordered path which fades away into a woodland, and these with other sights gladsome to lovers of such art have given Chesterwood its place in the ranks of beautiful gardens.

At Riverside Farm, overhanging the beautiful Tyringham Valley, and possessing possibly the most wonderful of all Berkshire views, is the dainty garden shown in the accompanying illustrations. It is the work of an artist, and truly a place of delight. The garden nestles to the hillside, enclosed in a low stone wall. On one side the sloping hill down which winding rough stone steps descend to the garden; on another side a rustic pergola and pool; the third side a line of old apple trees overhanging 


\section{BEAUTIFUL GARDENS IN AMERICA}

the wall; the fourth side contains the simple entrance, and beyond the boundaries on all three sides - the wonderful view.

At Naumkeag, Stockbridge, the formal garden full of bloom, which is part of a larger plan, has a wide-spread reputation. It is especially noted for its battlement-cut hedge, and has as an accessory a splendid landscape background, so common to the Berkshires and so desirable to the garden beautiful. "Naumkeag" is the Indian name for Salem, meaning "Haven of Rest."

Recently completed at Great Barrington, the spacious garden at Brookside is the best piece of Italian work in this section. The accompanying illustration gives but a faint idea of its size, its flowers, and its many other fine points.

The two pictures illustrating the garden at Overloch, Wenham, and at Rock Maple Farm, Hamilton, are still other good examples of the variety and charm of the flower planting of this coast State. Both of these views are unique, and in fact how seldom do we find sameness in gardens!

Mr. Longfellow's place at Cambridge, Doctor Weld's at Brookline, and The Witch's Place at Salem are typical of New England - the paths all edged with Box, which shrub, on account of frost blights, has never attained great height. These gardens are just simple, lovable little places filled with shadows and sunshine, some flowers, and the good scent of Box, which latter always seems so especially essential to old gardens. 


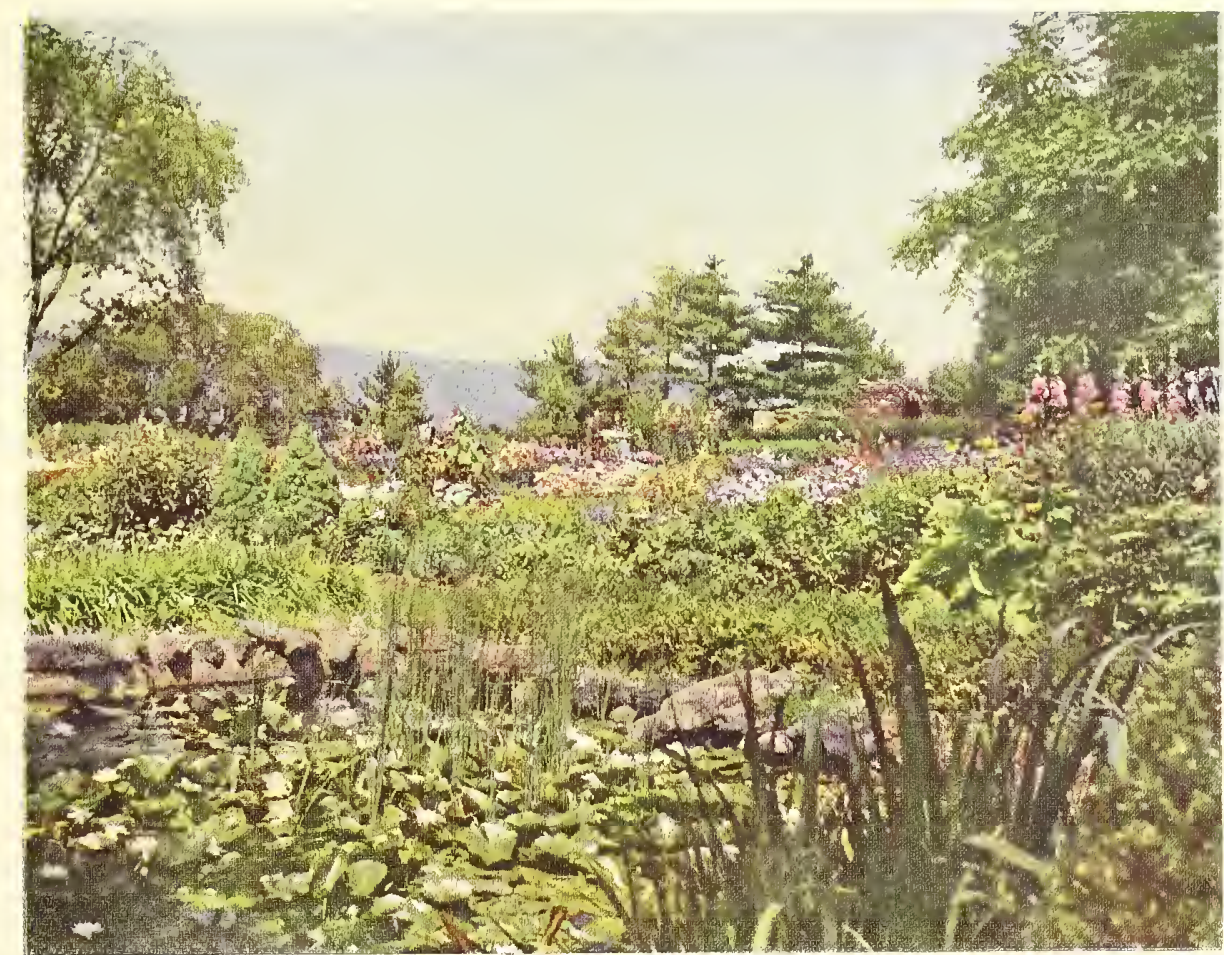

"Fairlawn"

PLATE ॥

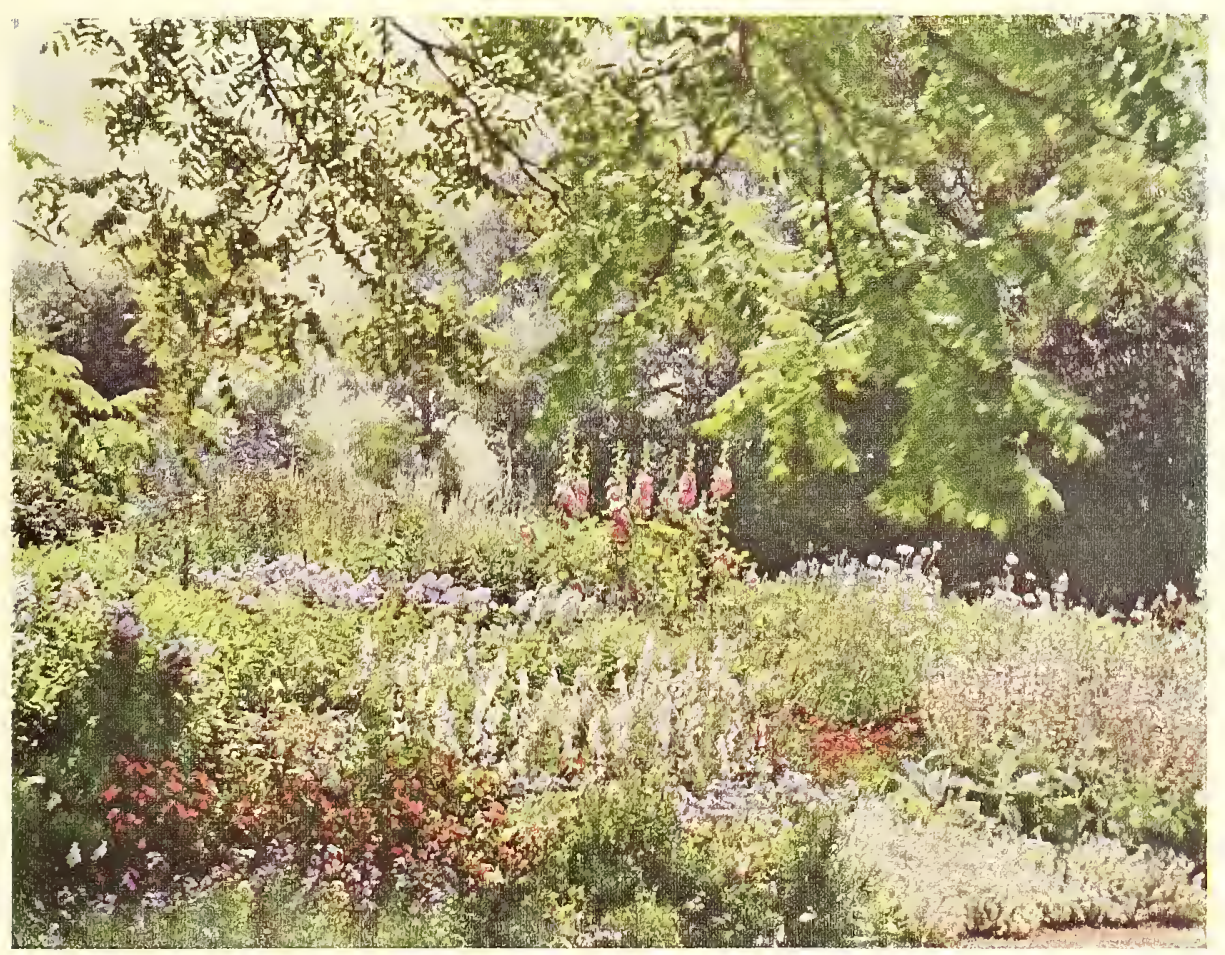

From autochrome photographs

PLATE II

"Fairlawn," Lenox, Mass. Miss Kneeland 



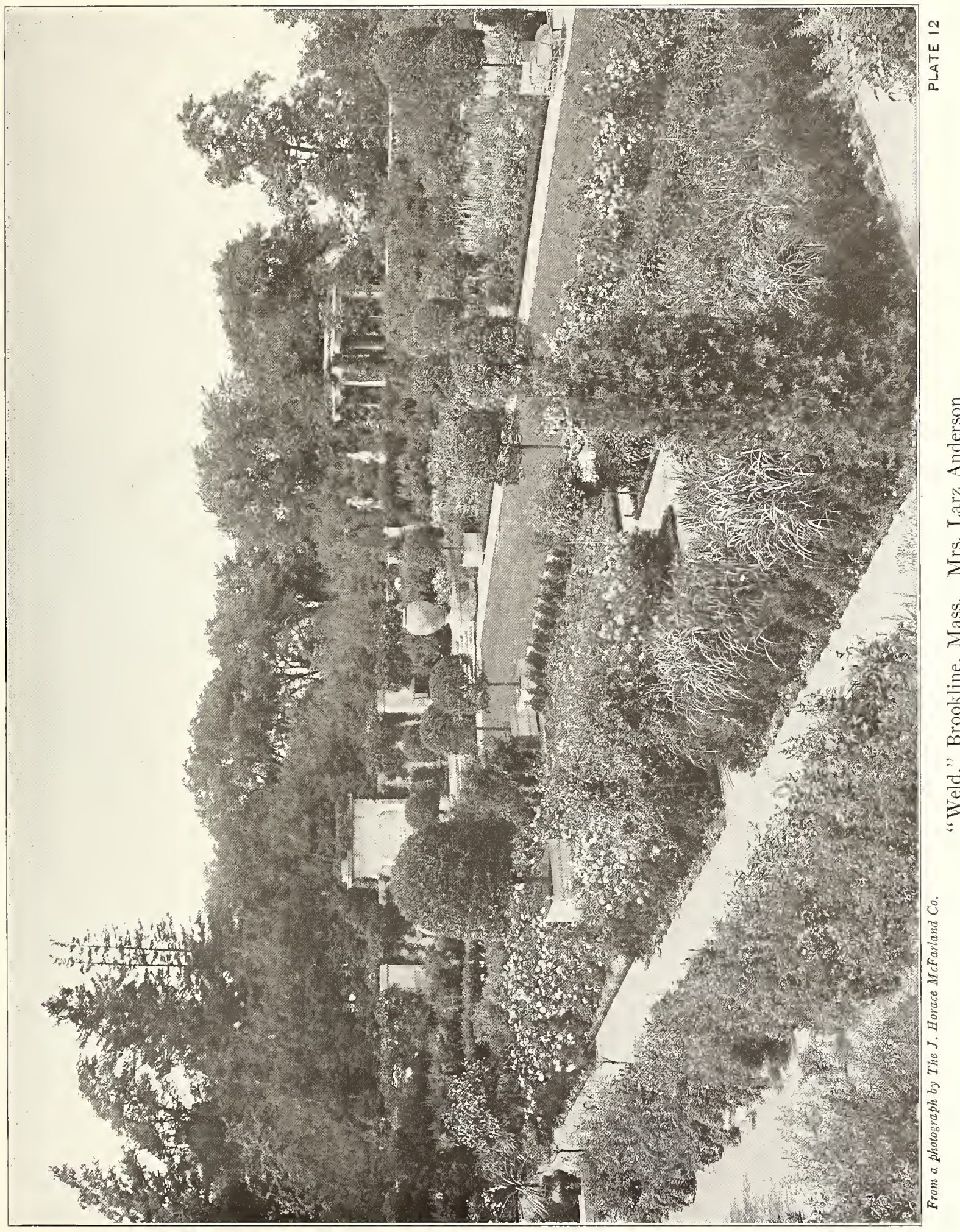





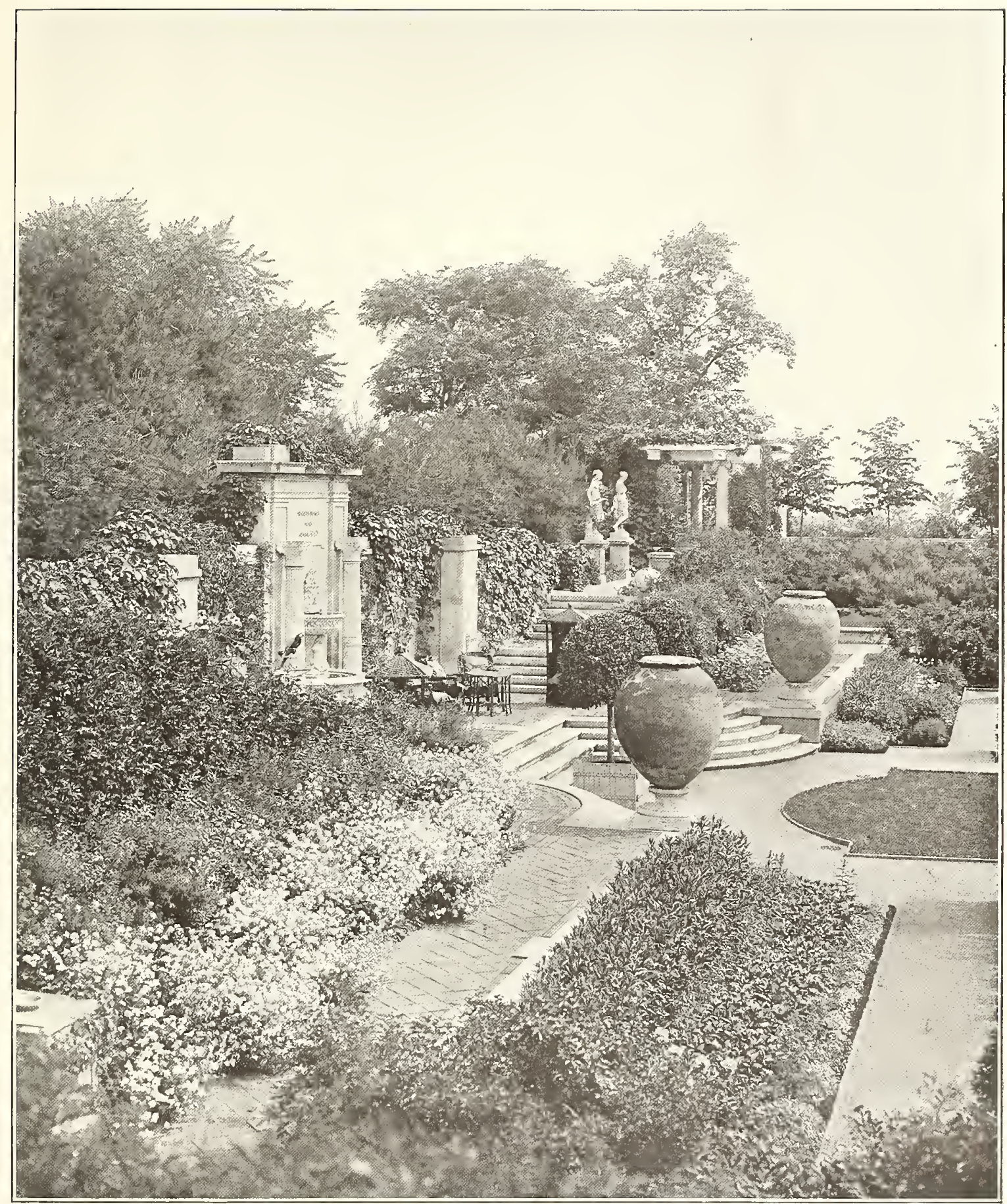

From a photograph by Thomas Marr and Son

PLATE 13

"Weld," Brookline, Mass. Mrs. Larz Anderson 



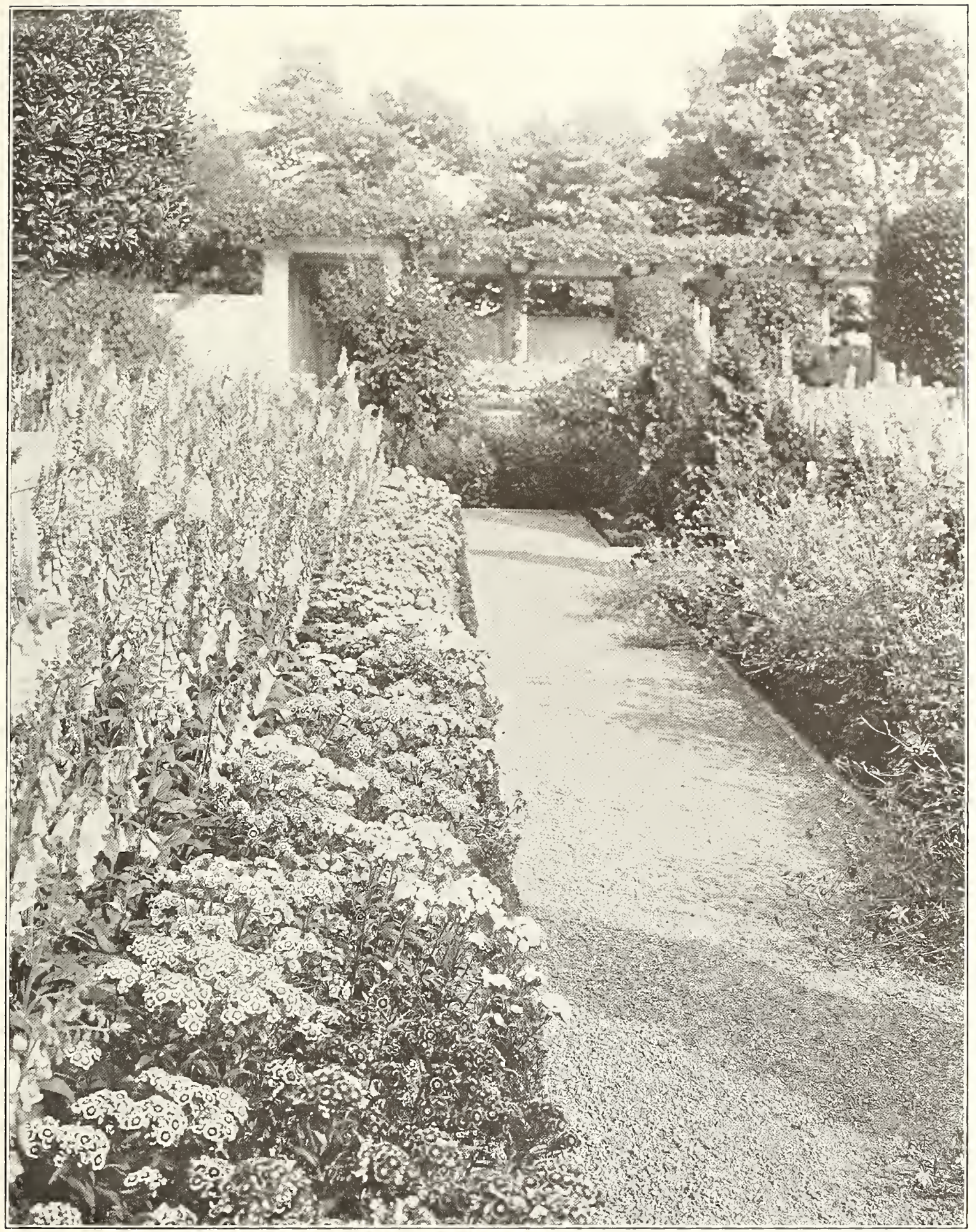

From a pholograph by Thomas Marr and Son

PLATE 14

"Weld," Brookline, Mass. Mrs. Larz Anderson 



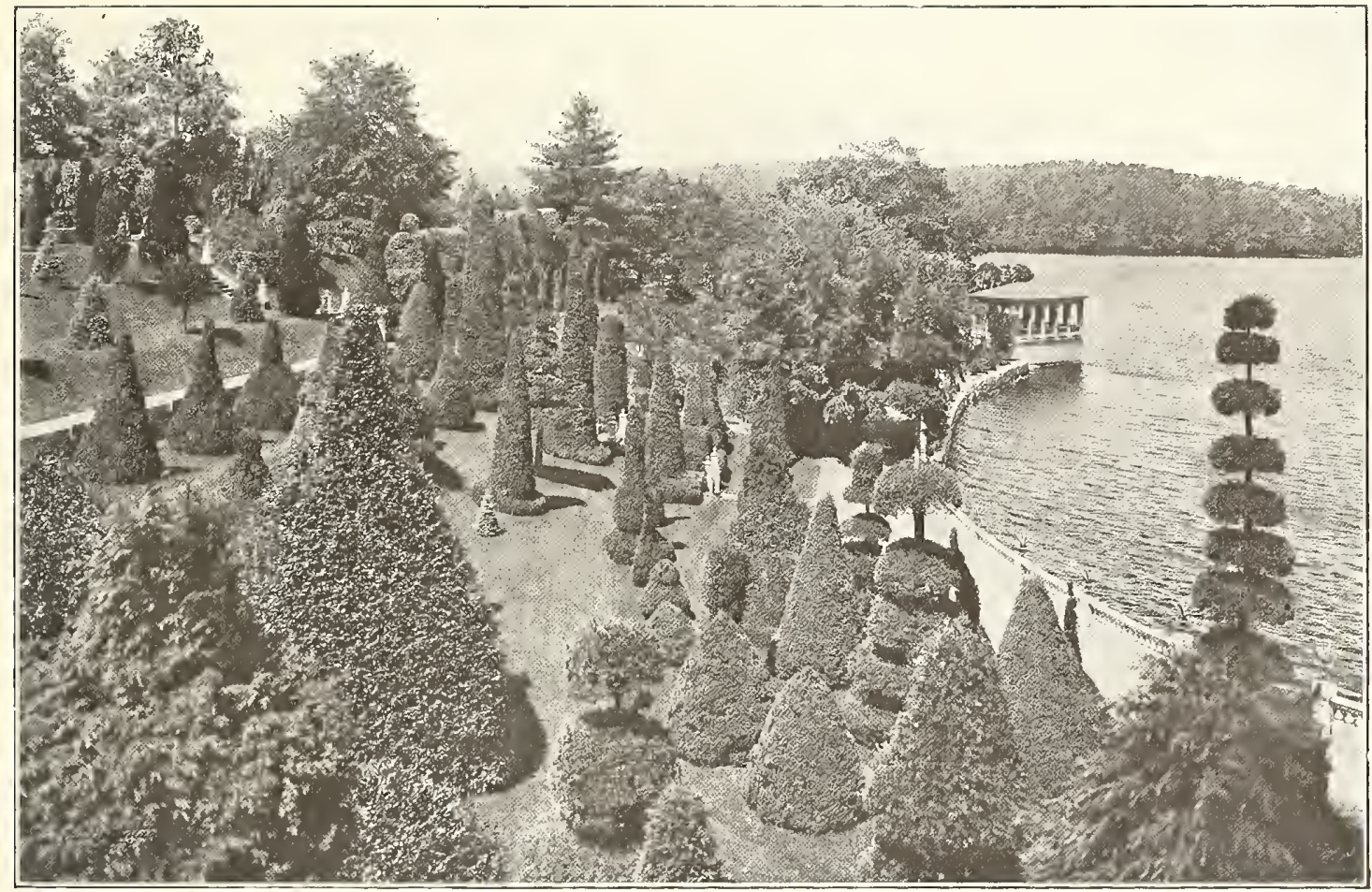

From a photograph by Wurts Bros.

PLATE 15

Wellesley, Mass. H. H. Hunnewell, Esq.

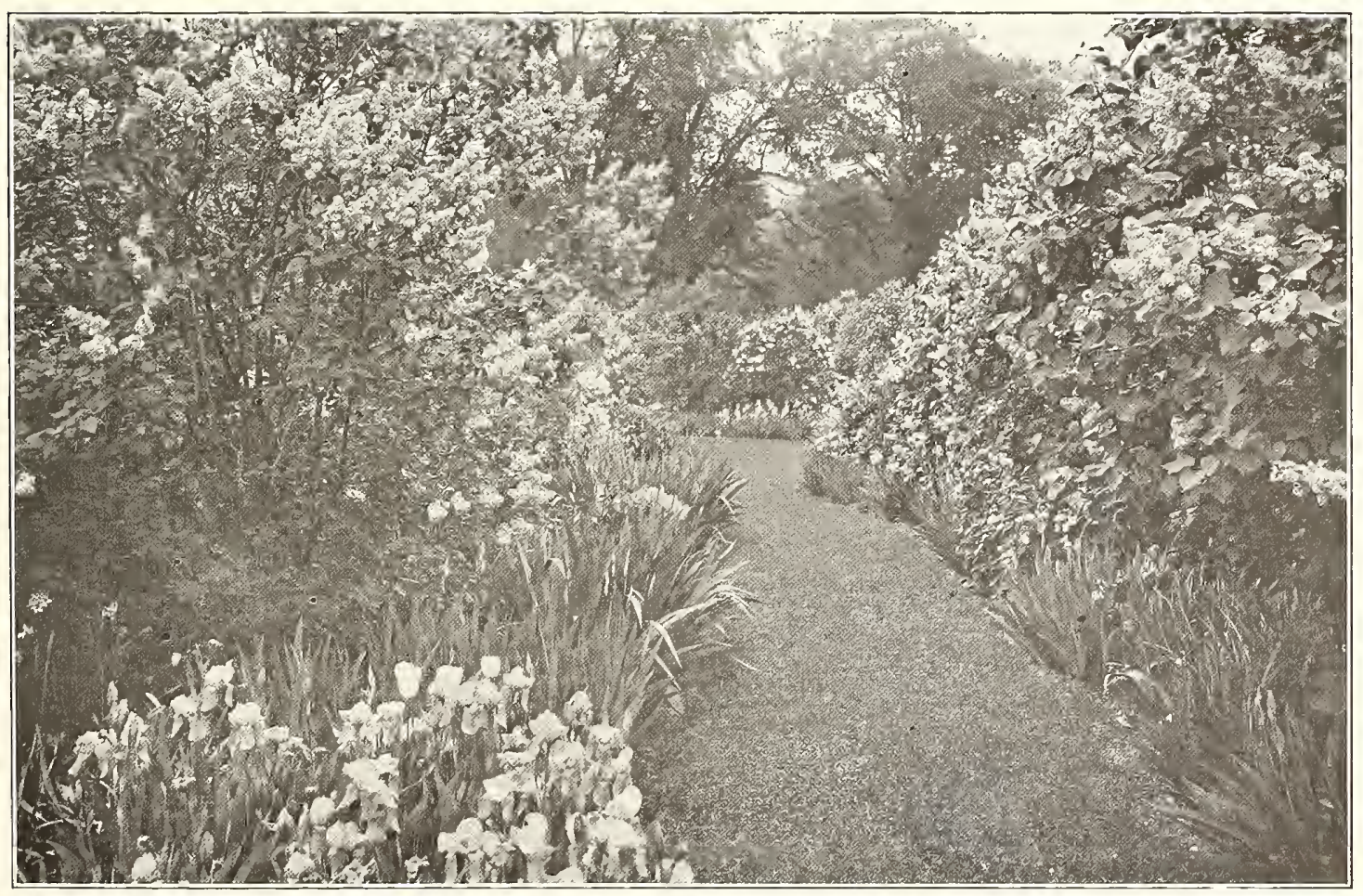

From a photograph by The J. Horace McFarland Co.

PLATE 16

"Holm Lea," Brookline, Mass. Professor C. S. Sargent 


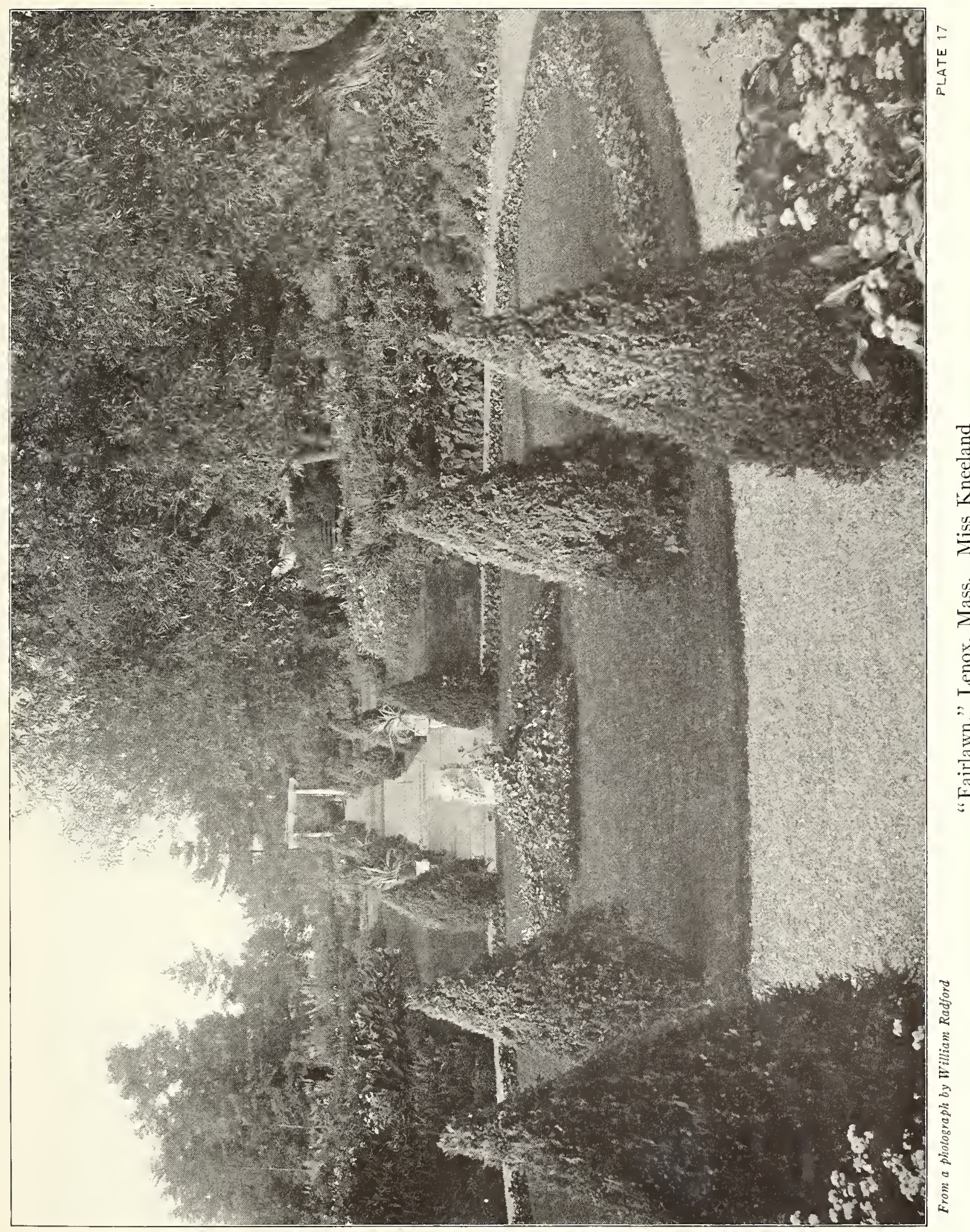





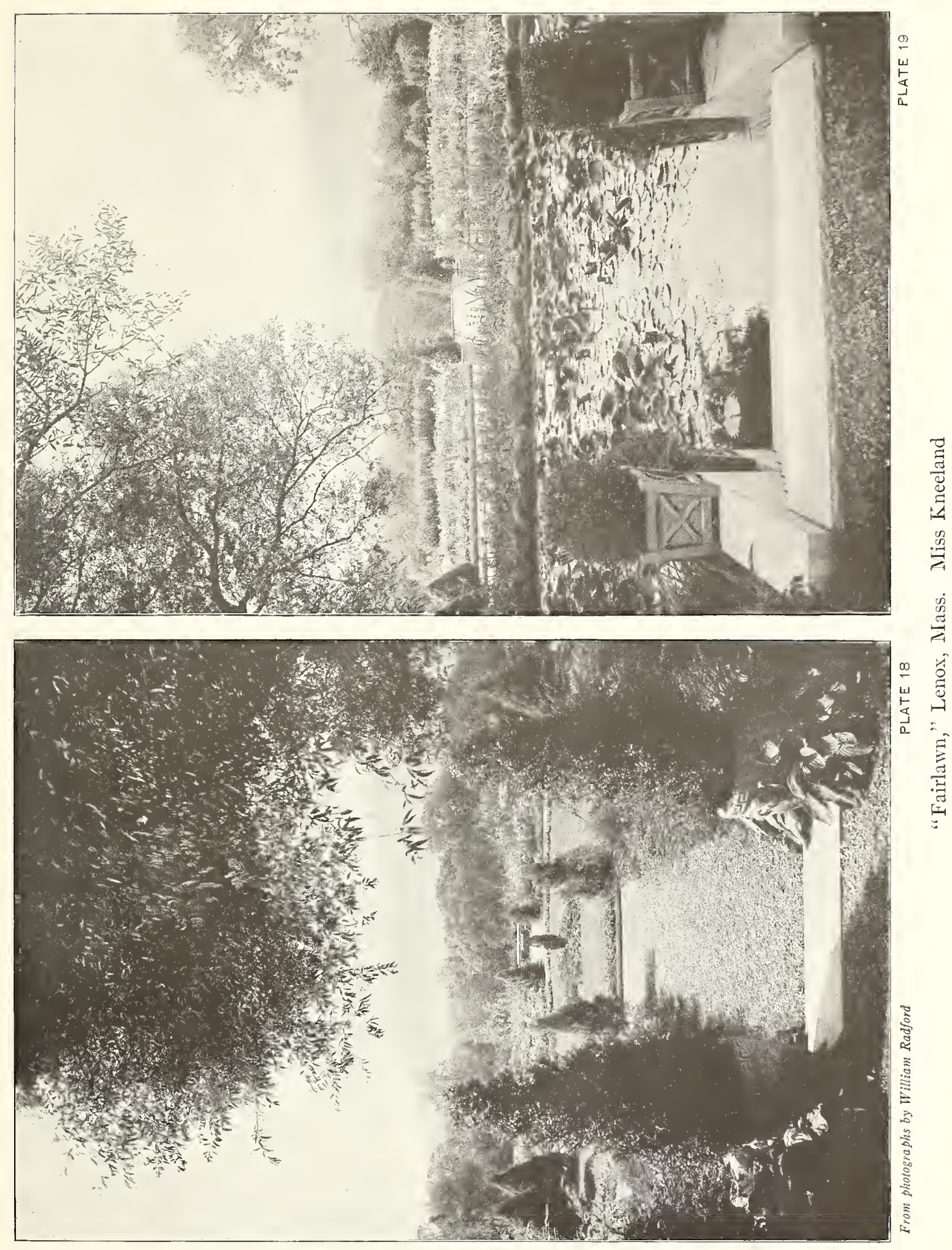





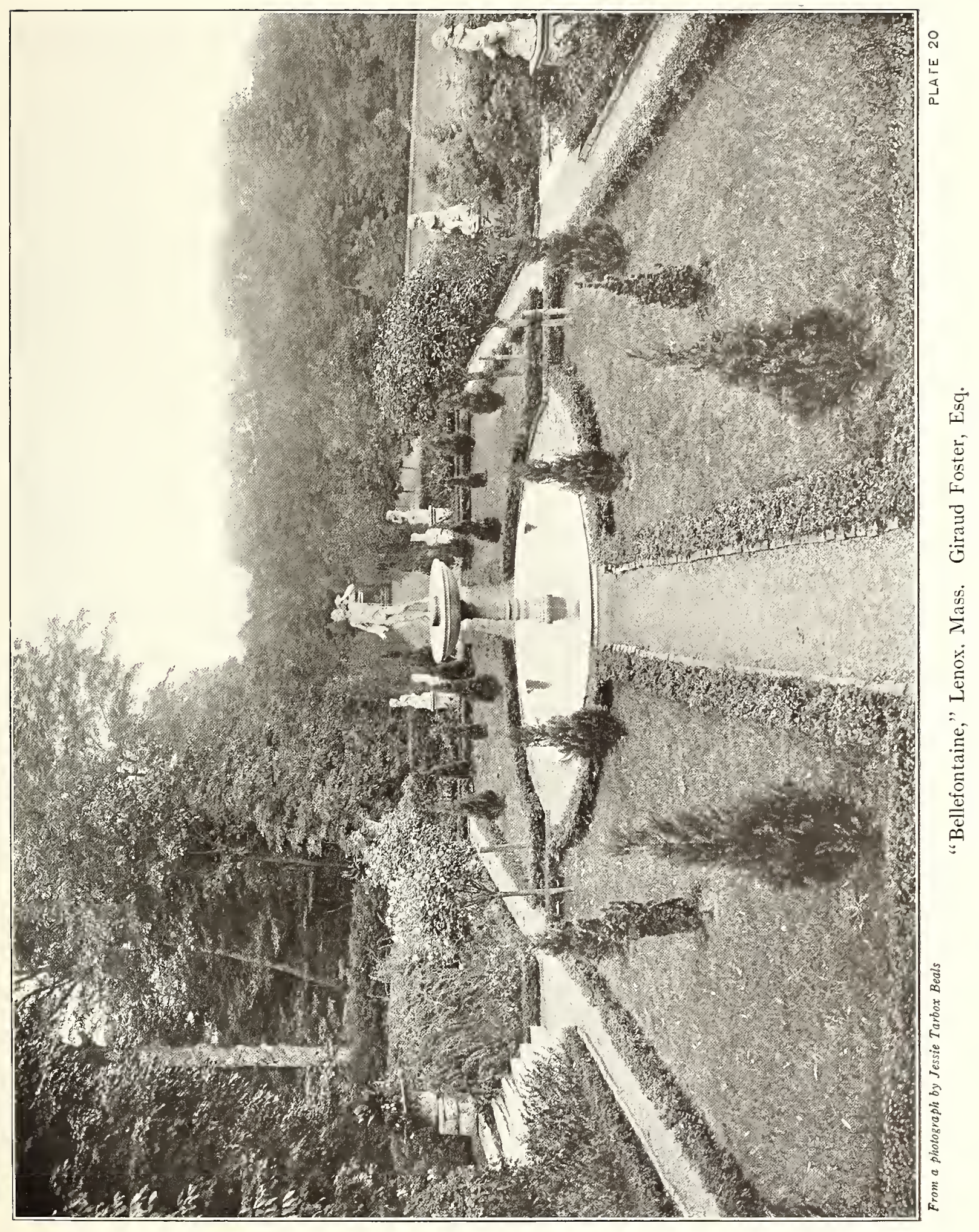





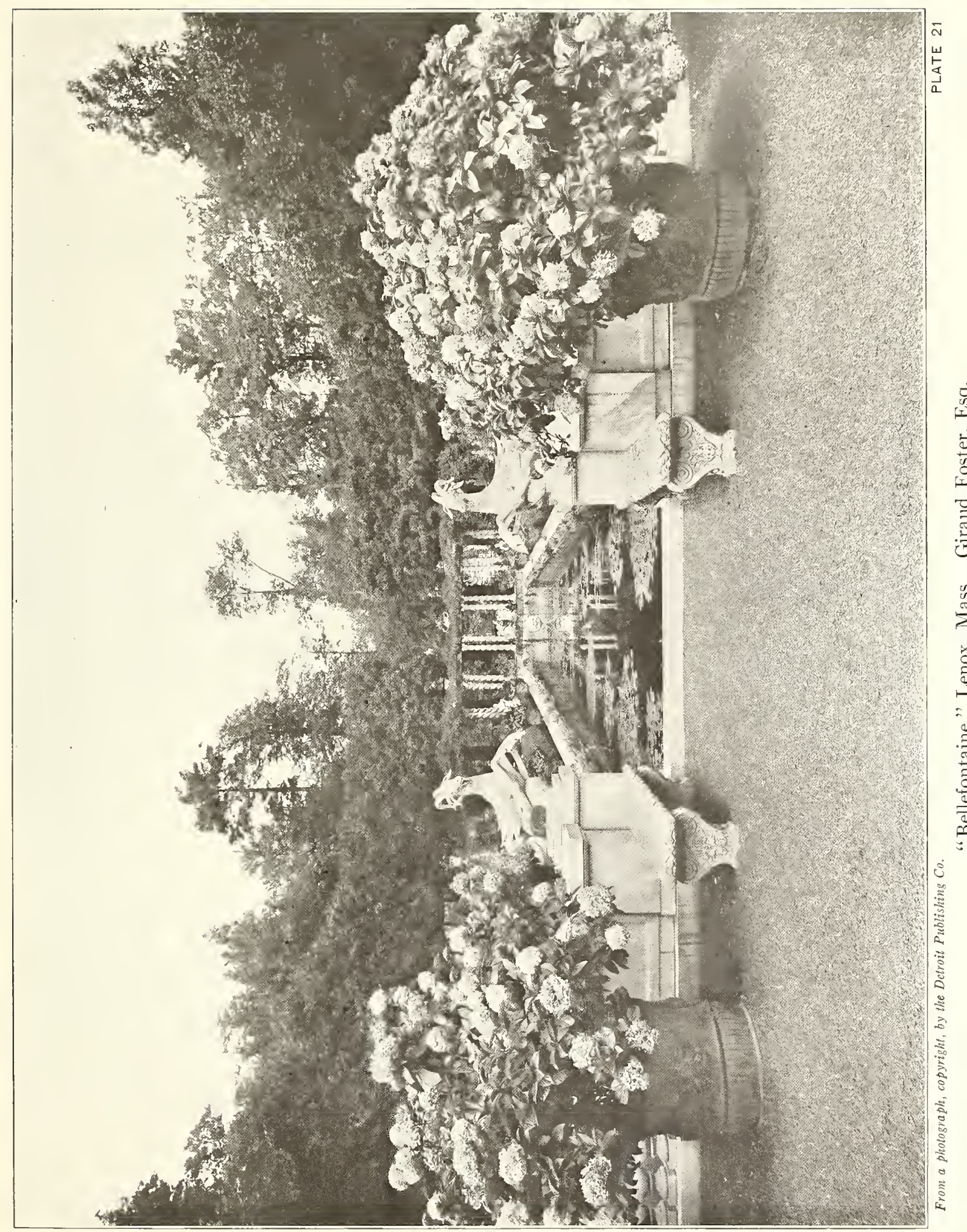





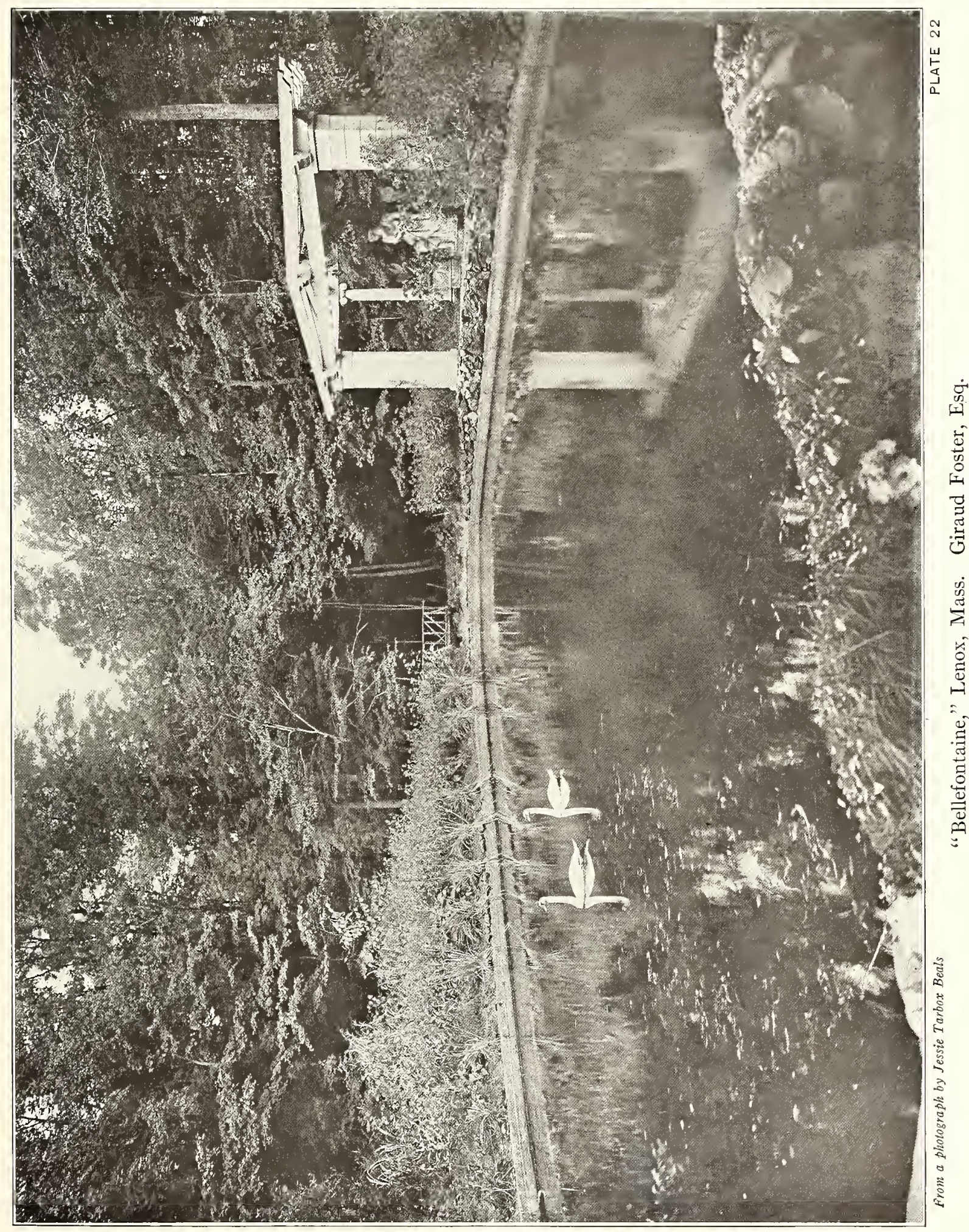





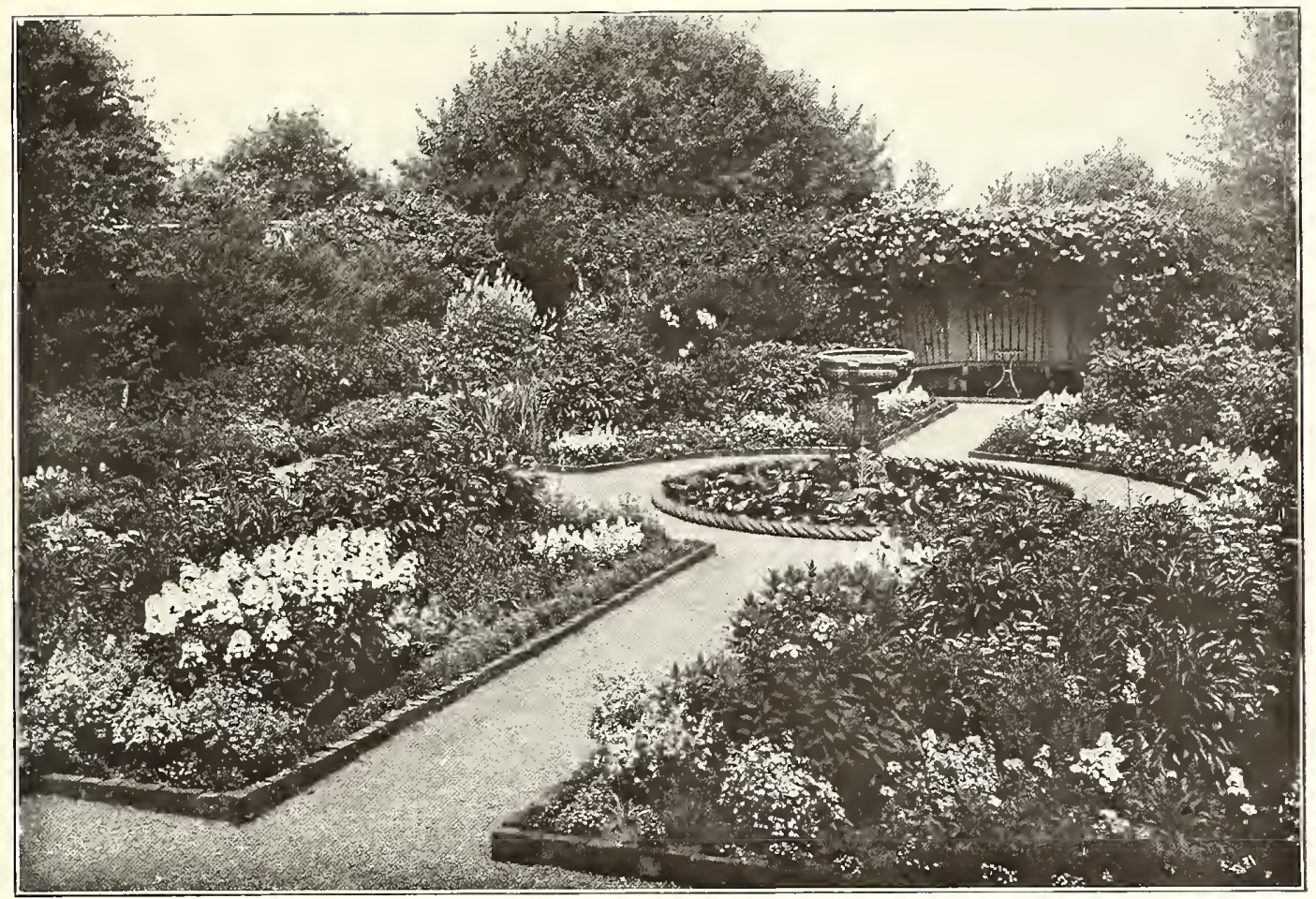

From a photograph by Miss M. I. Northend

PLATE 23

"Overloch," Wenham, Mass. J. A. Burnham, Esq.

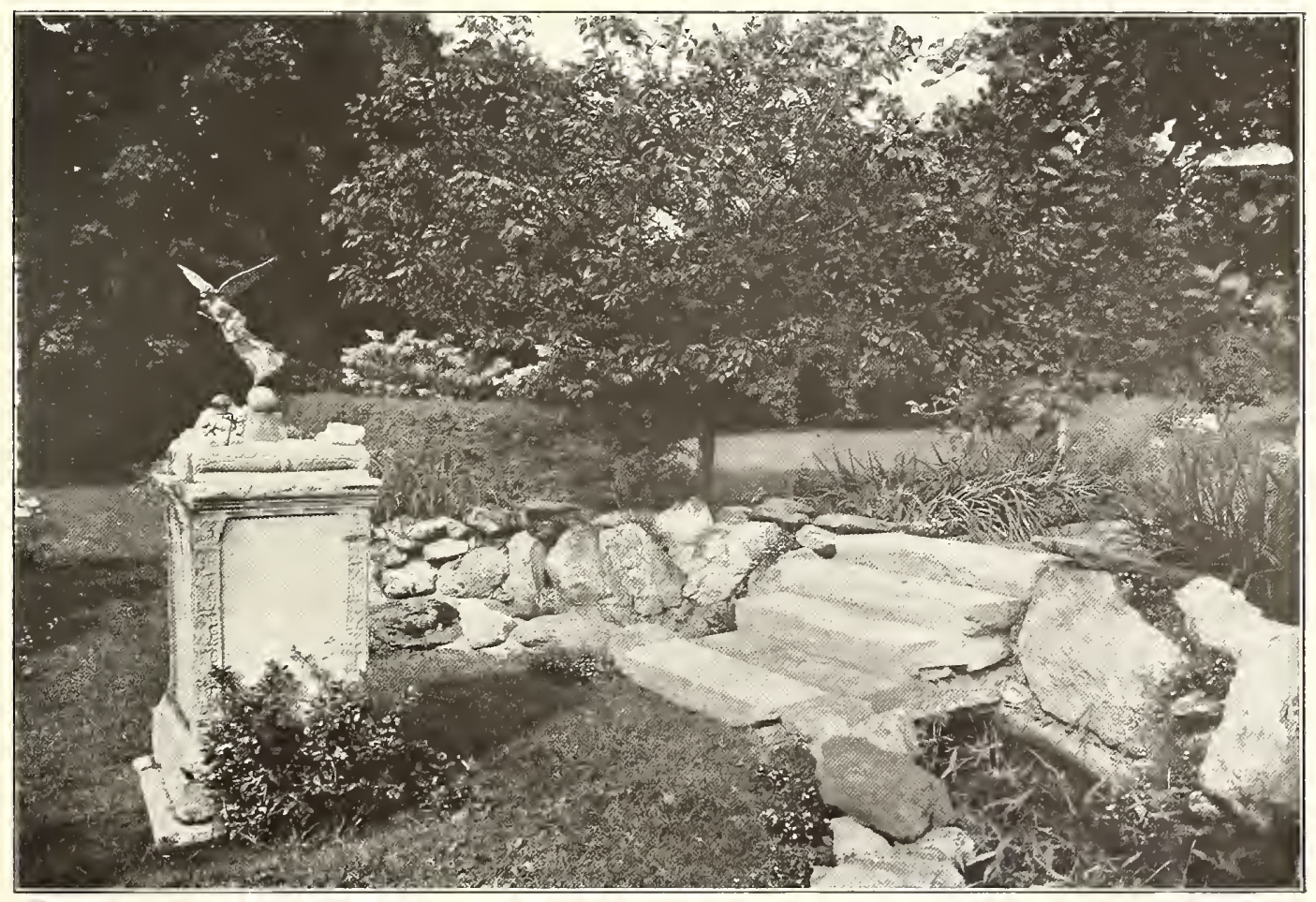

From a photograph by Jessie Tarbox Beals

PLATE 24

"Fernbrooke," Lenox, Mass. Thomas Shields Clark, Esq. 



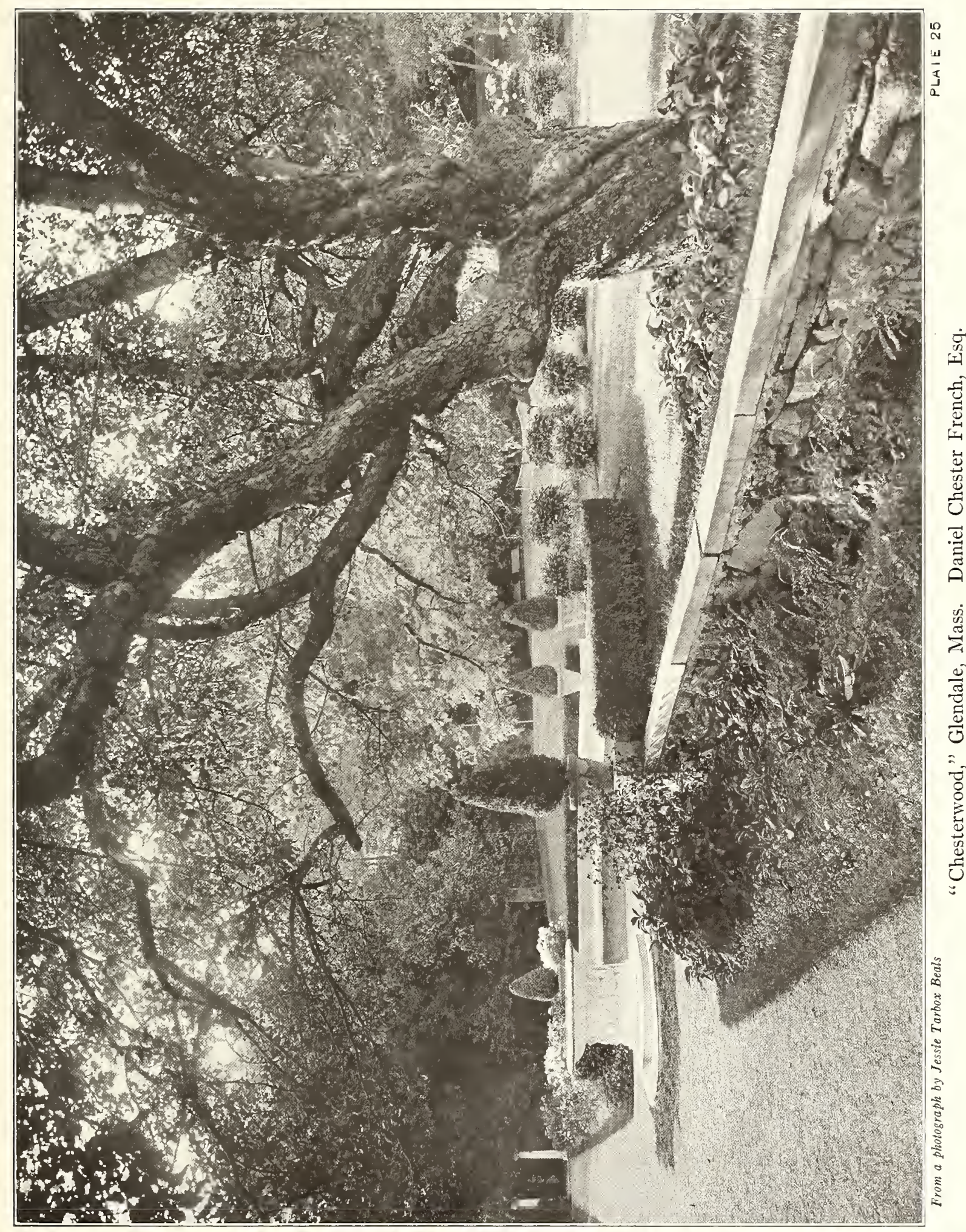





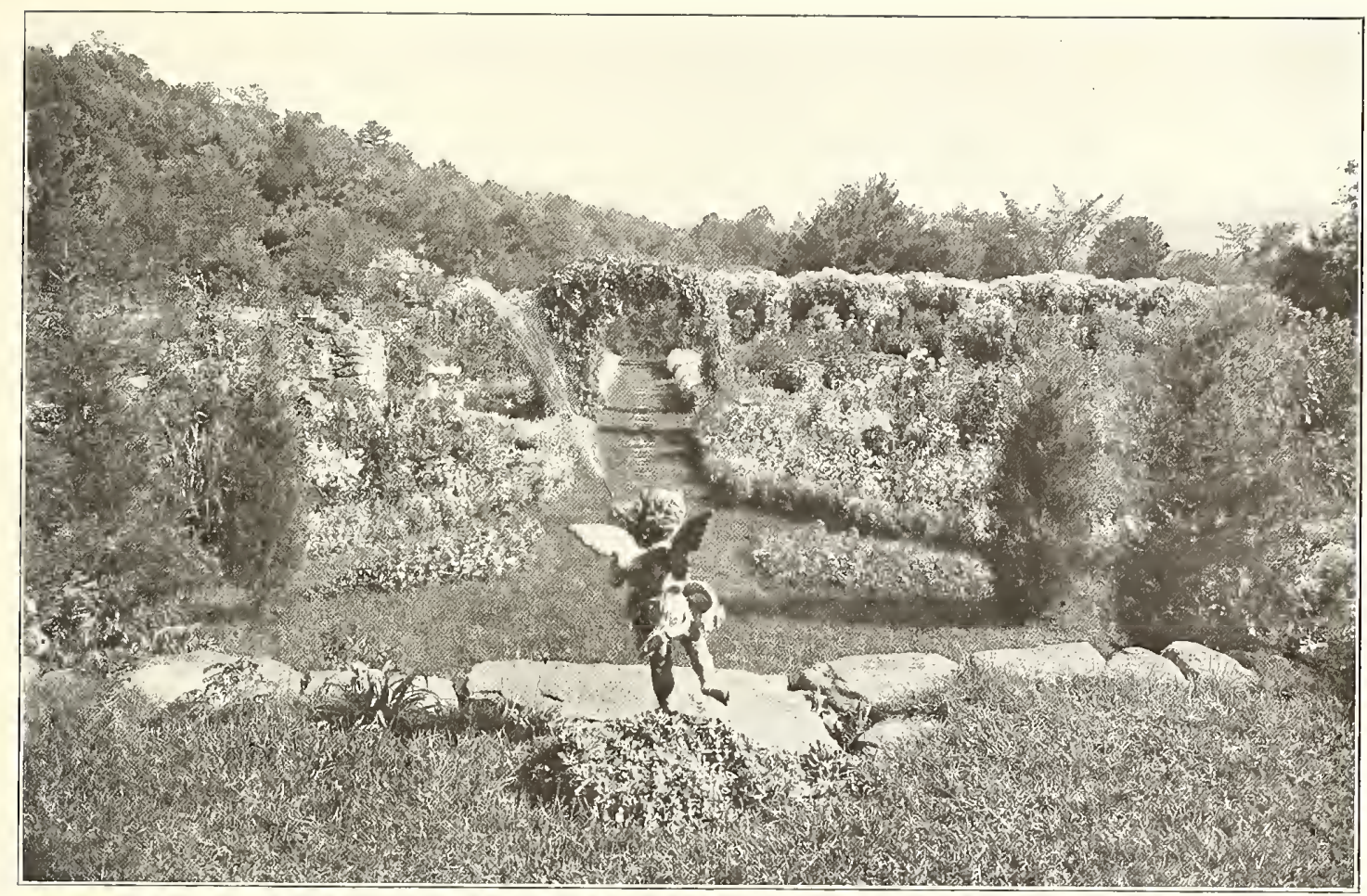

PLATE 26

"Riverside Farm," Tyringham, Mass. Mrs. Banyer Clarkson

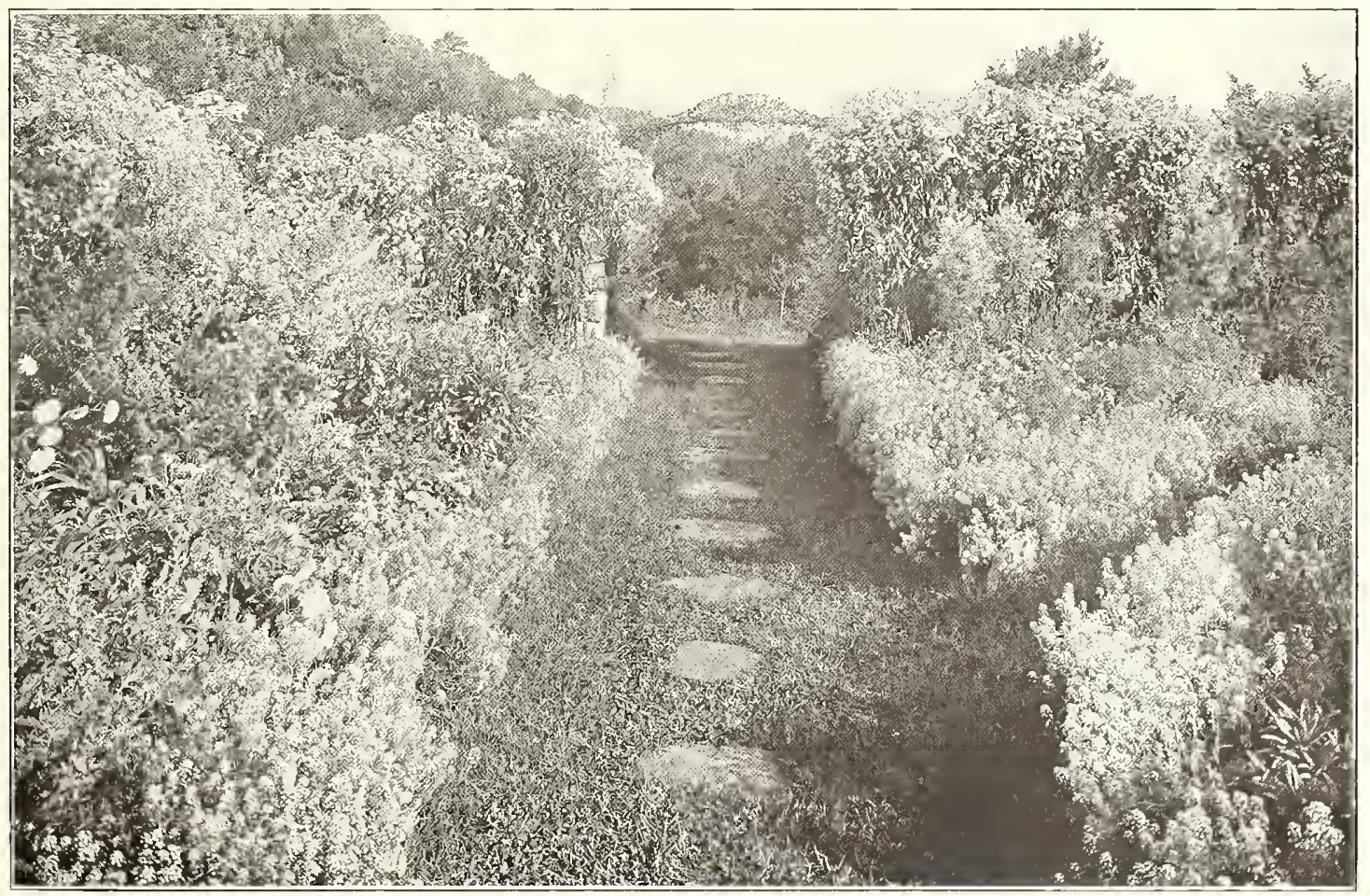

From photographs by Jessie Tarbox Beals

PLATE 27

"Riverside Farm," Tyringham, Mass. Mrs. Banyer Clarkson 



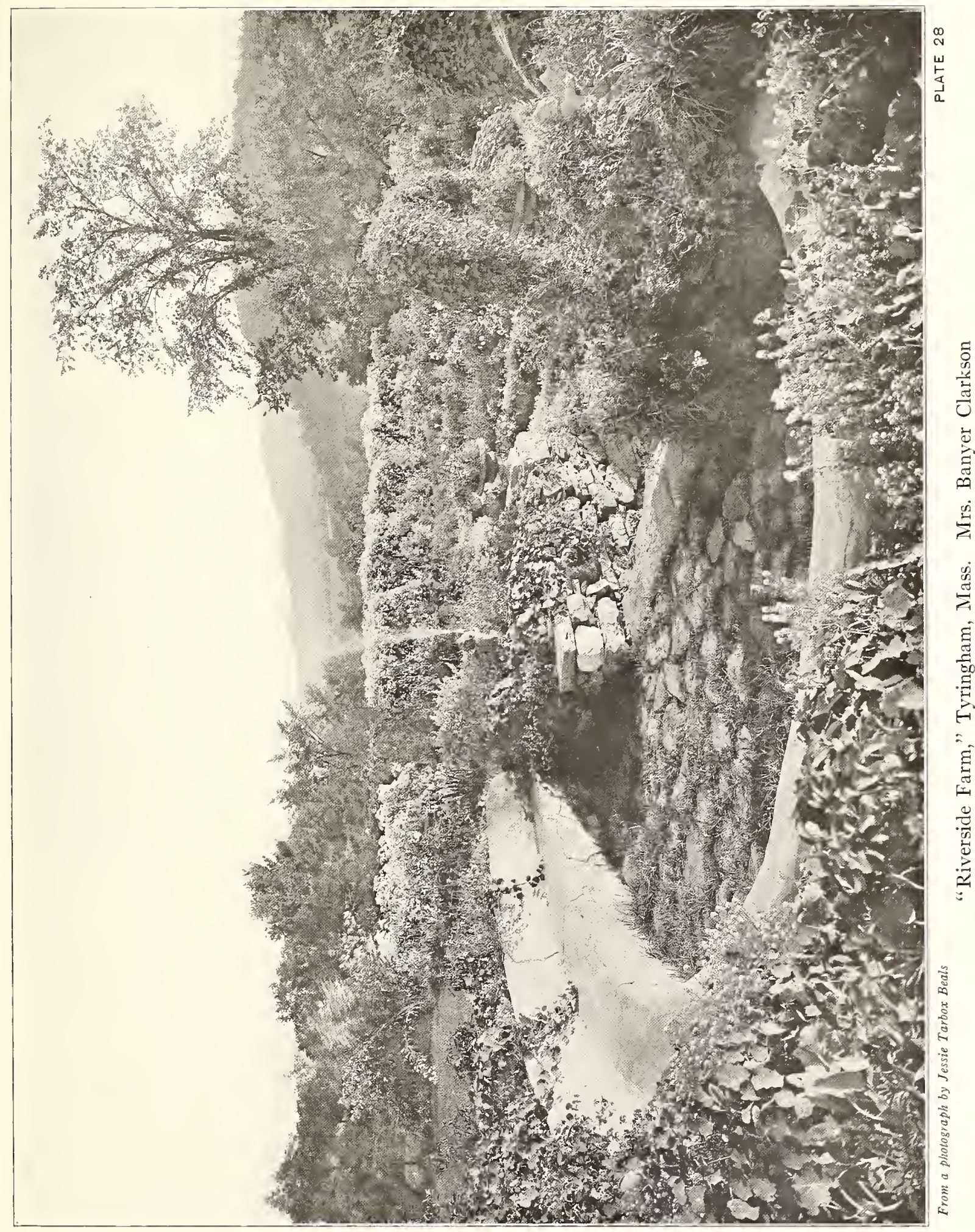





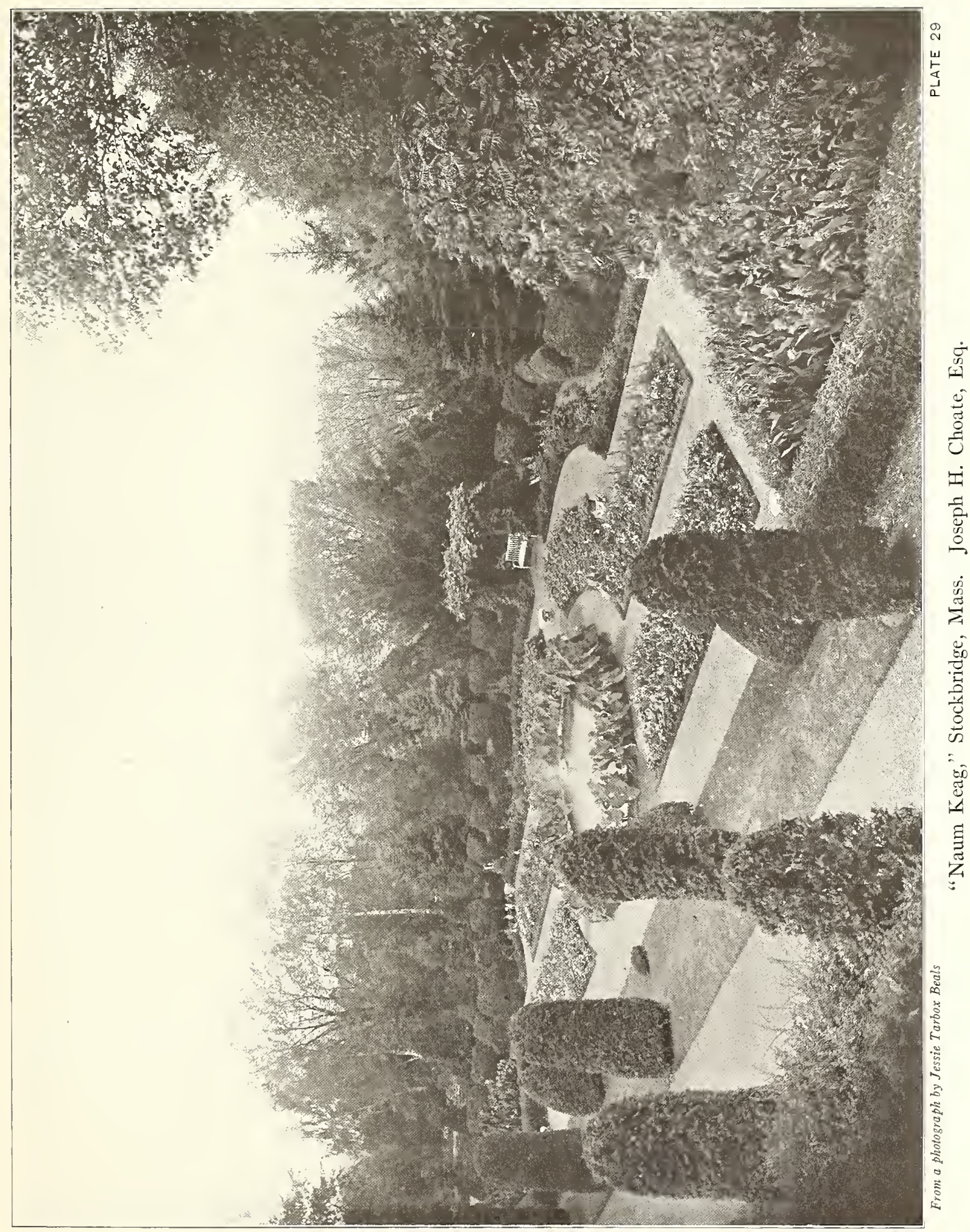




.




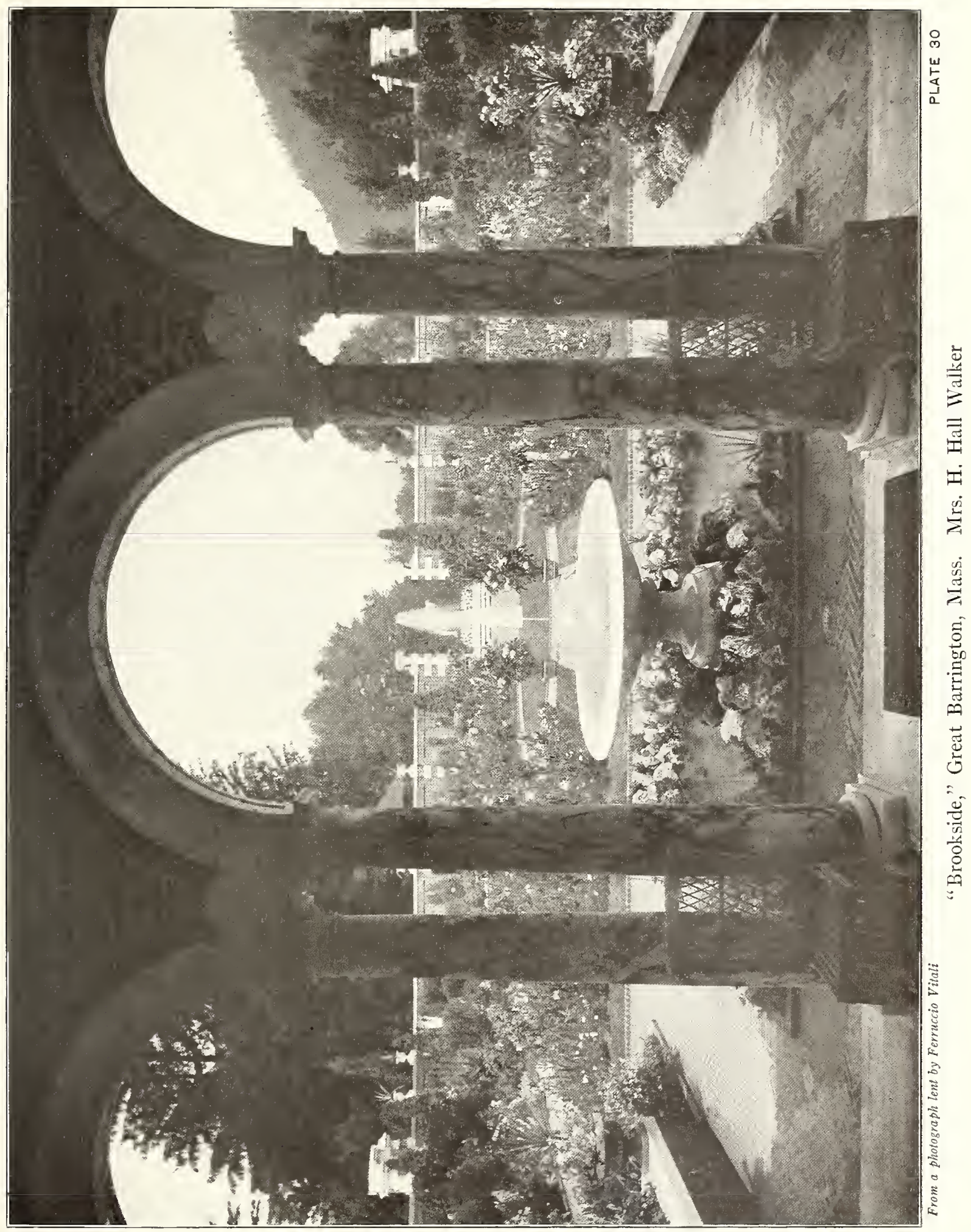





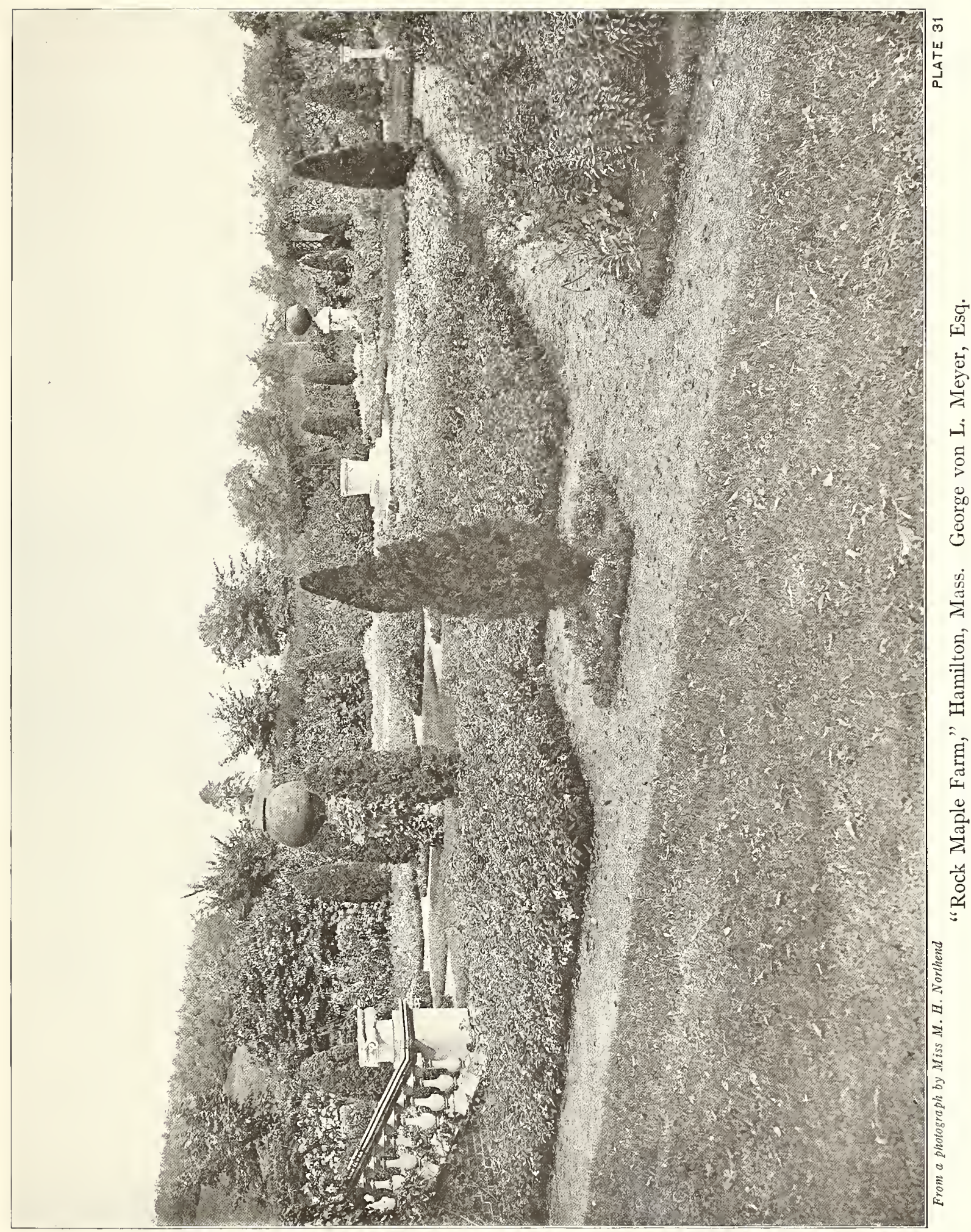





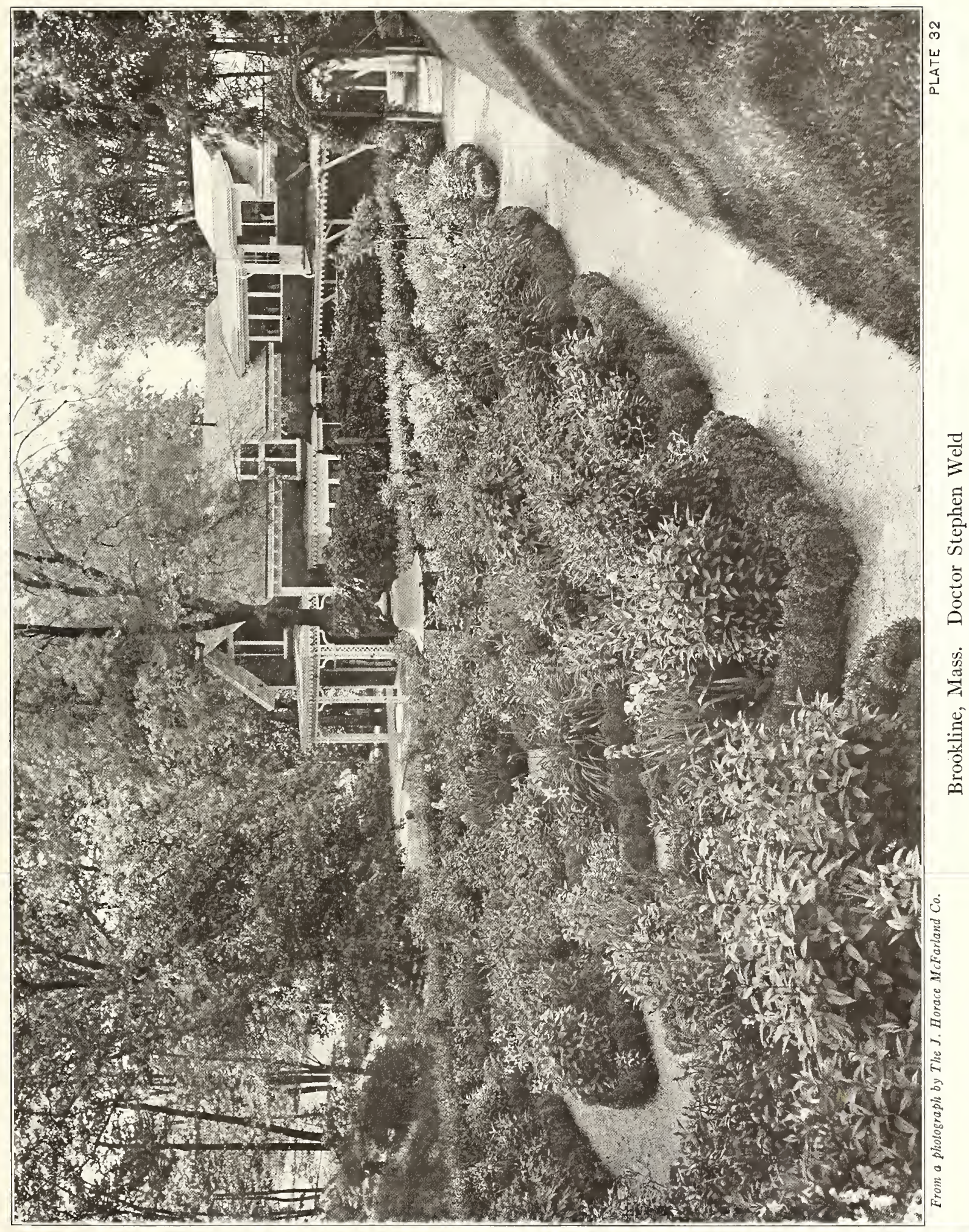





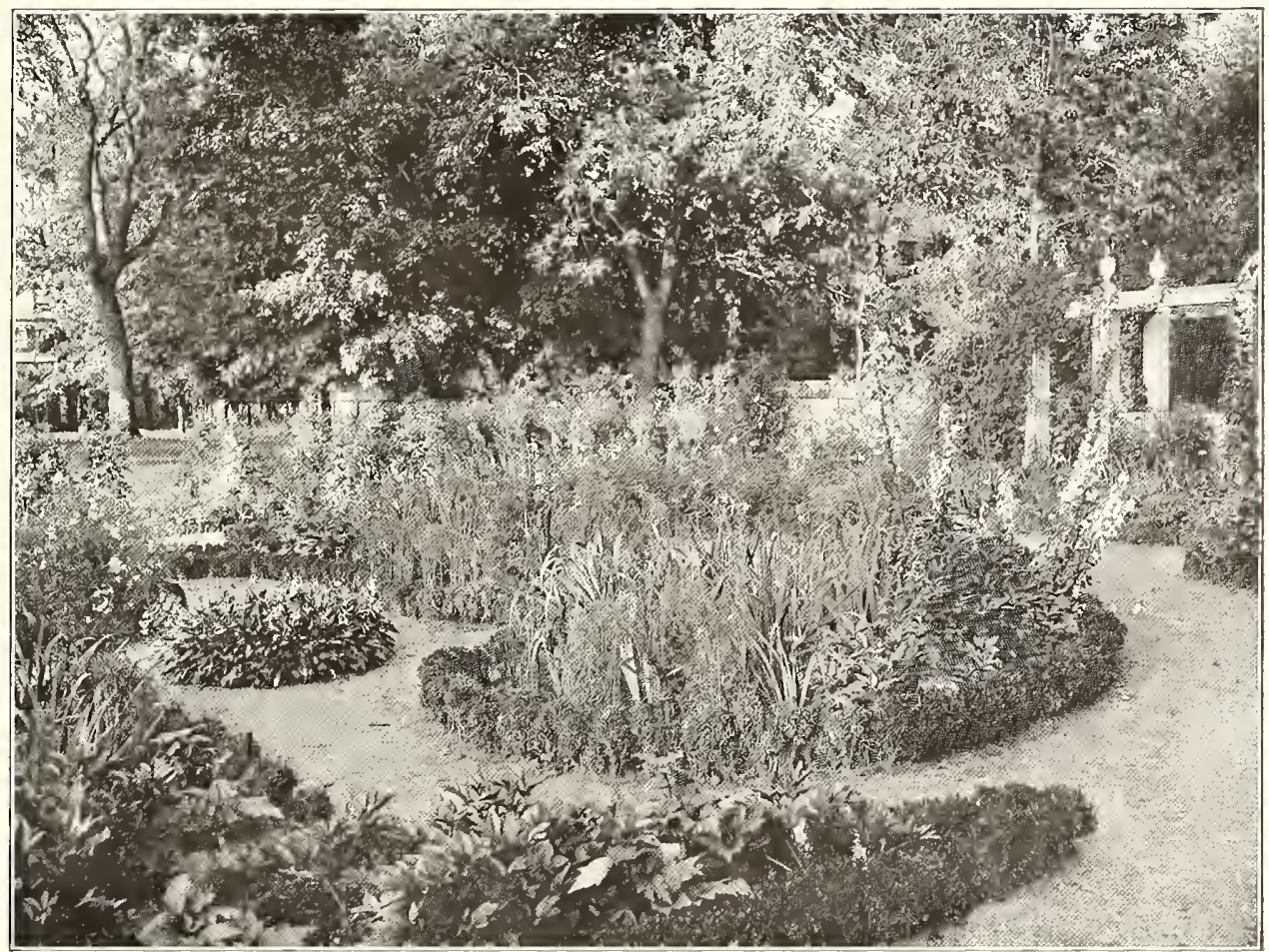

From a photograph by The J. Borace McFarland Co.

PLATE 33

Longfellow's Garden, Cambridge, Mass.

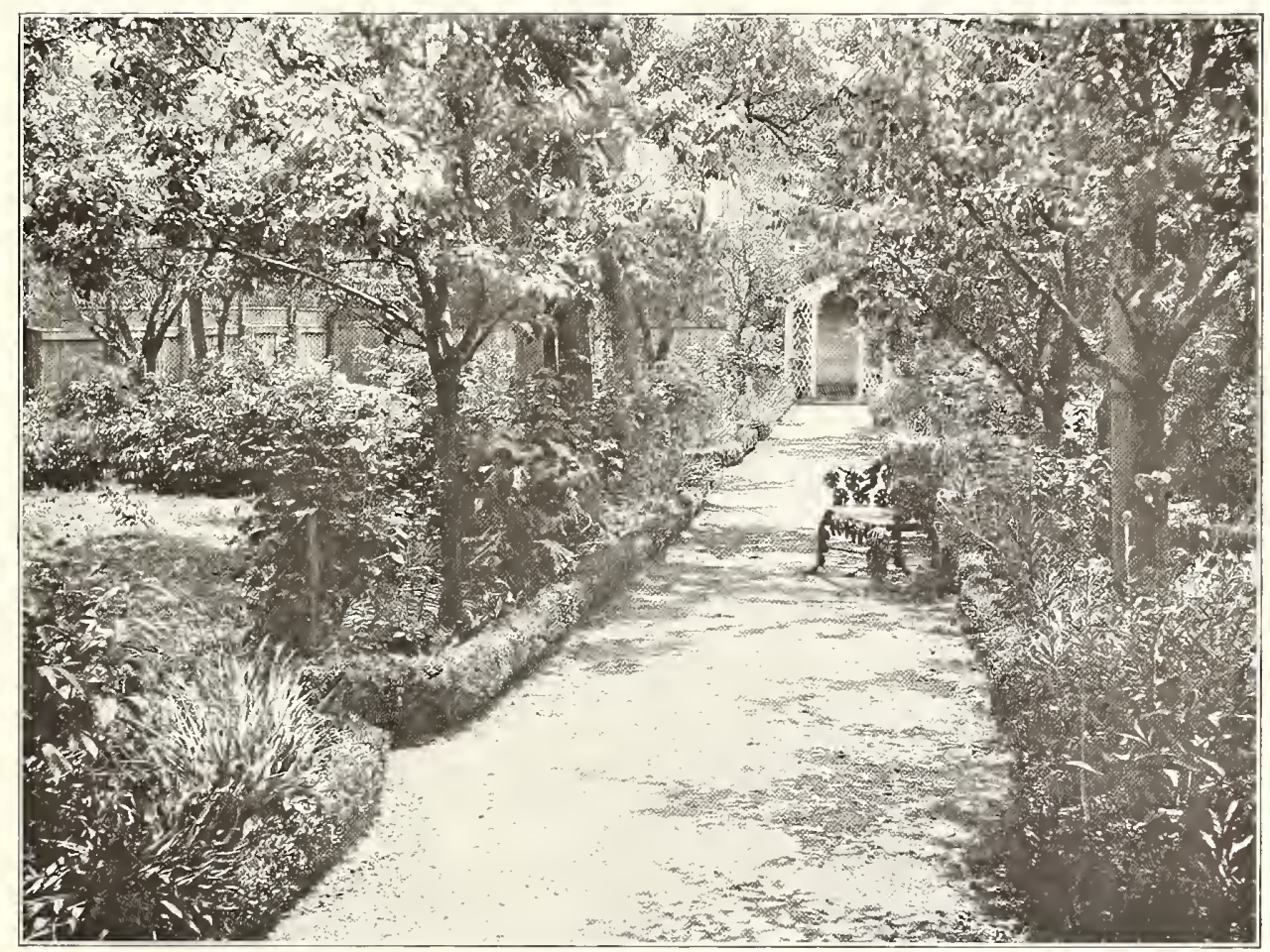

From a photograph by G. A. Spence

PLATE 34

Old Witch House, Salem, Mass. 


\section{RHODE ISLAND}

Limited space permits but a suggestion of the various types of planting along the Atlantic coast, which promises to become almost a continuous garden by the sea from New Jersey to Maine. Rhode Island contains some of the most magnificent places in the country, the majority of them situated near bay or sea, where they thrive in congenial environment. The quality of the climate as it affects plant life will be easily realized after reading of the climatic conditions of Massachusetts as well as of those to the south, on Long Island, for instance.

The older gardens are found in the vicinity of Providence, while at Narragansett and Newport those of a later period abound. Newport by the sea, more famous than any other American summer resort, naturally possesses the greatest number of gardens on an elaborate scale. The coast at this point is somewhat sheltered, the air is mild, and there is sea moisture so beneficial to flowers. Windbreaks of hedges or walls are used where the winds blow strong off the water.

Lovely and lovingly planned is the garden at Mariemont, a poetical spot, overflowing with color and sunshine, yet with shadowy retreats, and the stillness that belongs to an enclosure of grass paths. It might be taken for a bit of foreign garden from any part of the world, and possesses a quality of beauty of which one could never tire. The long, broad path with its brilliant 


\section{BEAUTIFUL GARDENS IN AMERICA}

border and distant vista is the central division of a charming plan.*

Few estates in America are as imposing and as suggestive of the grandeur of an Italian or English country-seat as The Elms, and it is probably among the oldest of Newport's famous places. The illustration is limited to a narrow view of this great, green formal garden in some sections of which flowers are included in rich profusion.

Probably no place at Newport is more noted for its beauty than Vernon Court, and, while necessity forces the omission of pictures showing many of its most elaborate features, a view of the stately formal garden is a welcome addition to this collection which aims to present a variety in types of planting in a few large formal gardens, as well as in those which are smaller and more personal. Vernon Court is not a new garden; it is unspoiled by garish accessories, and to the lover of the garden majestic it represents a perfect type.

At Warren, near Providence, the place at Villaserra is delightfully located, sloping to a bay. Here is one of the favored gardens where old trees take an important part; in fact, of such consequence are they that the garden was undoubtedly made to the scheme of the trees and the water beyond - a beautiful sanctuary of blossoms and green life, shut in from the discord of the outside world.

* See also the frontispiece. 


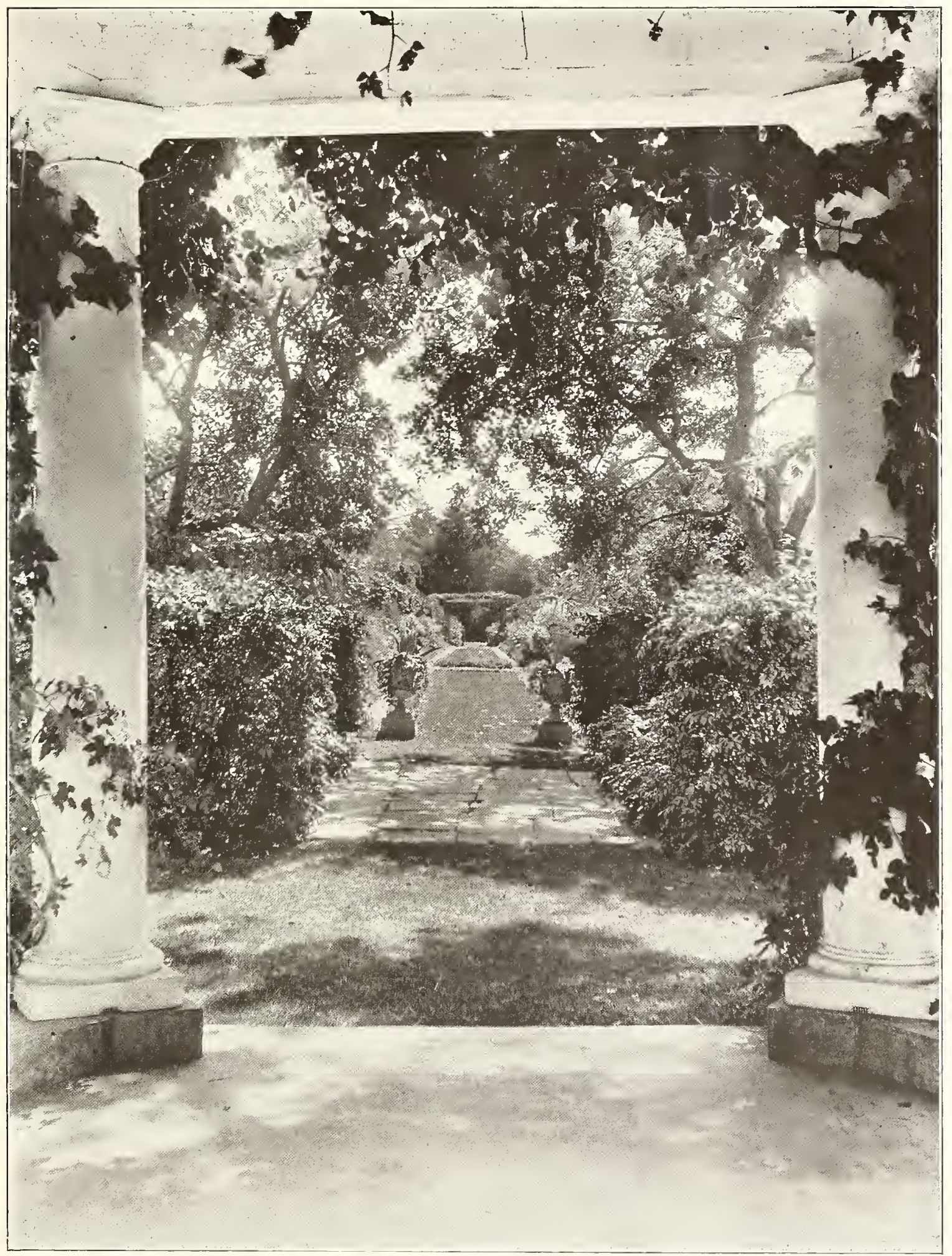

From a photograph, copyright, by Miss Johnston-Mrs. Hewitt

"Mariemont," Newport, R. I. Mrs. Thomas J. Emory 



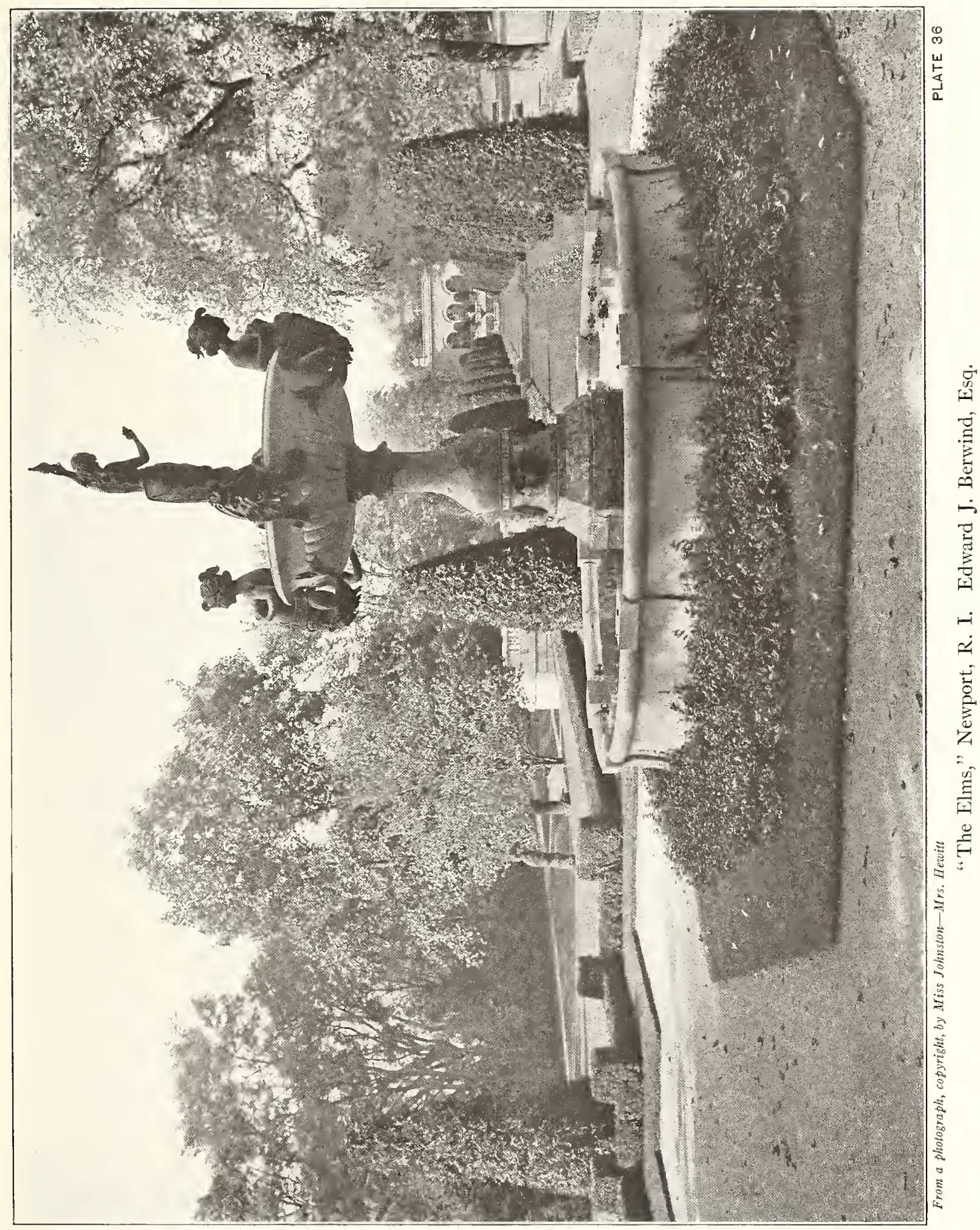





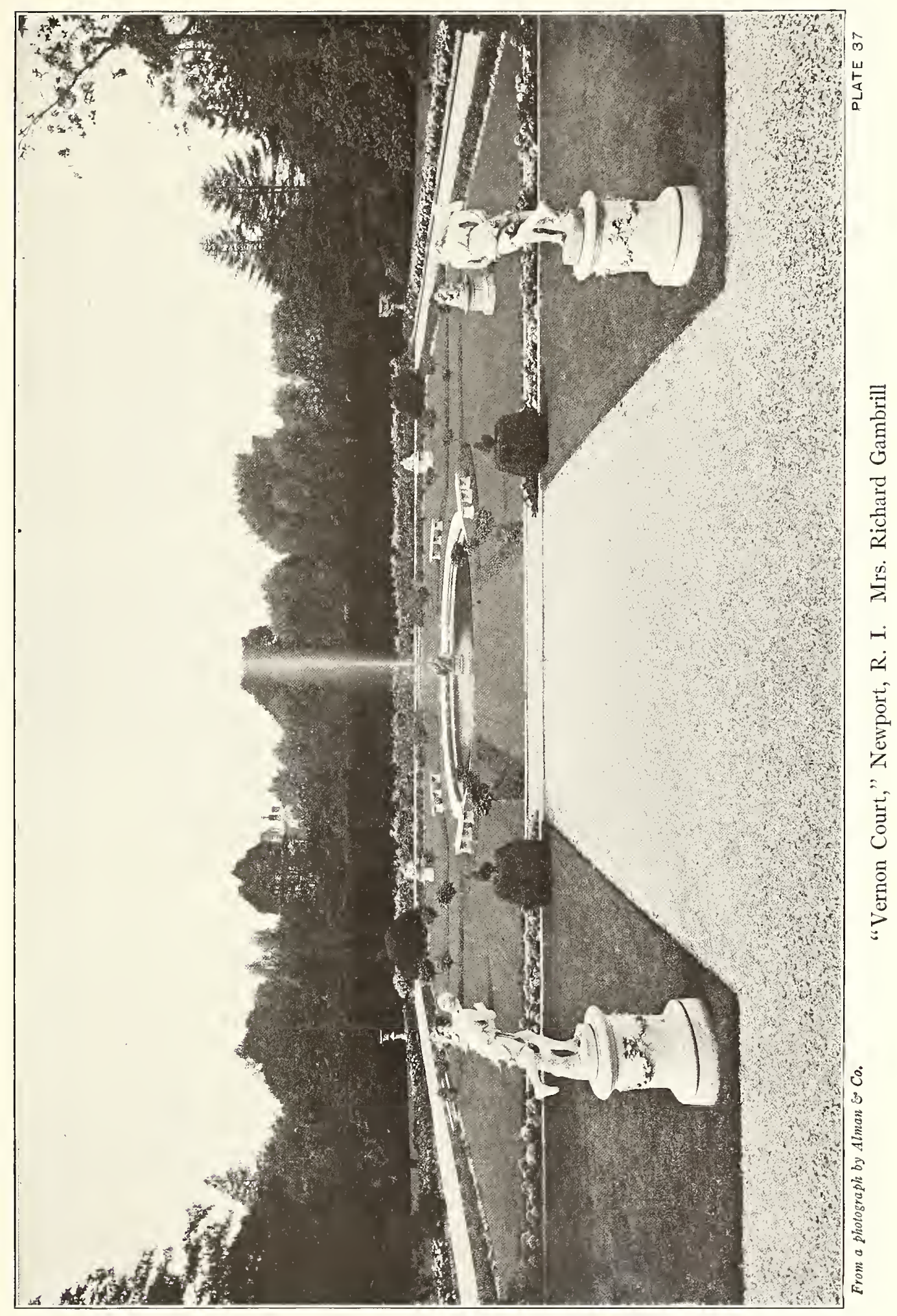





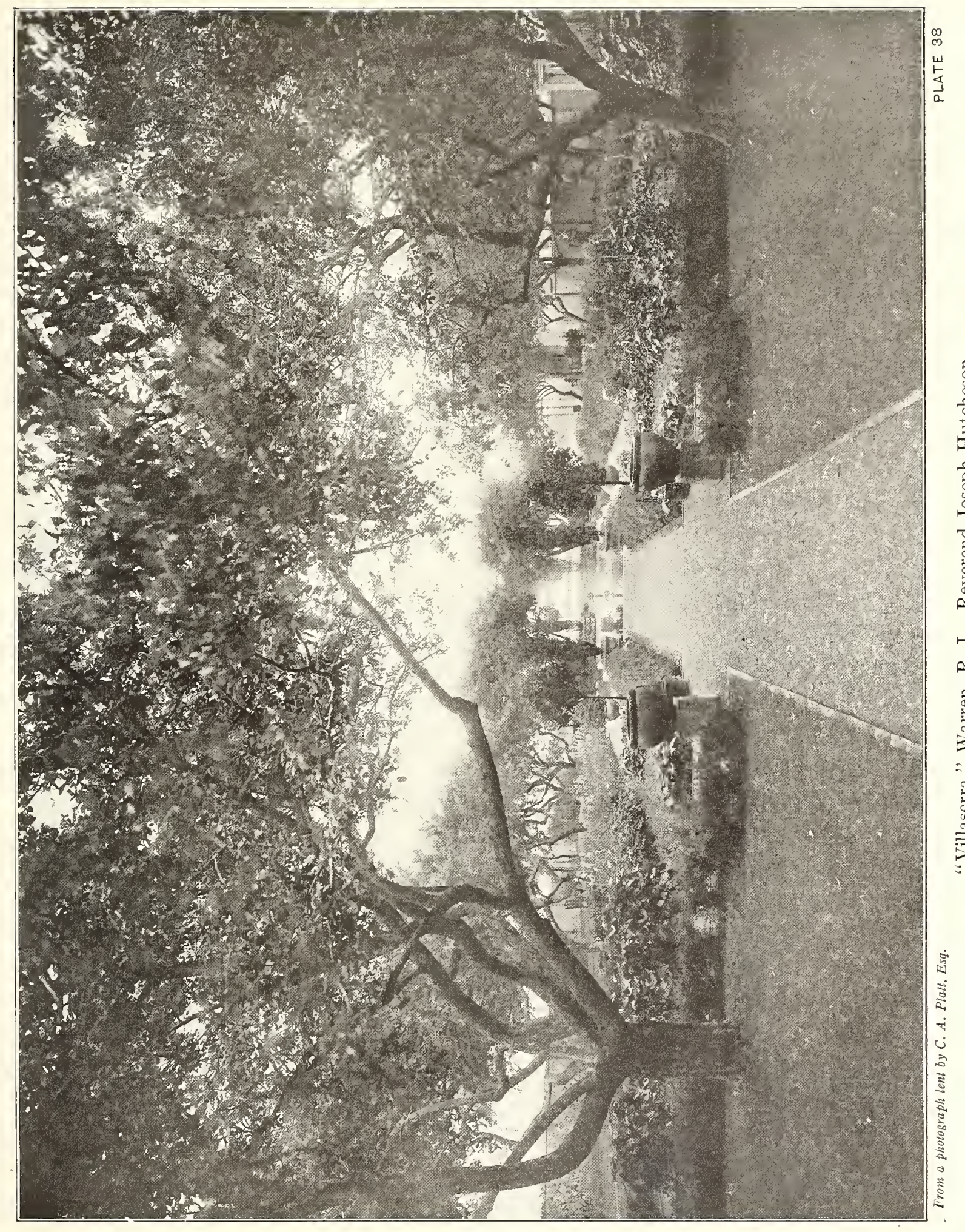




\section{CONNECTICUT}

Connecticut gardens are many, both inland and along the shores of the Sound. Those of the hilly western section have the advantage of a somewhat cooler altitude. Otherwise it is unnecessary to give further details as to climatic conditions, ${ }^{*}$ as the northern boundary is about a hundred miles distant from northern New Jersey and the temperatures differ but little, although of course every hundred miles northward makes gardening a somewhat simpler proposition, because of slightly cooler conditions as well as a shortened flower season.

In a reputed true story of the long-ago settlement of Old Saybrook there is mention of a woman's flowergarden, doubtless the earliest on Long Island Sound. Here the sheltered inlets and bays must have seemed a welcome haven to our Pilgrim fathers from the windswept coast of Plymouth, whence they had wandered, probably seeking fertile farmland. The gardens of this State, with some notable exceptions, are mainly those of a simpler type, made and tended by their owners, who living in them, will continue to beautify them more and more as time goes on. These unpretentious creations of flower lovers often show originality not always found in gardens of a more formal design, and might be considered typically American.

Following the idea of simplicity, the first two illustra-

* These climatic conditions are explained in New Jersey chapter. 


\section{BEAUTIFUL GARDENS IN AMERICA}

tions of this chapter portray the "lovesome spot," where flowers predominate, with nothing to recall the splendor of other lands. A place for the harboring of flowers for the sake of the flowers, and this was surely the thought that brooded over the first New England gardens planted in the early half of the seventeenth century, when American gardens had their beginning.

The glimpse through the arched gateway of the garden at Knock-Mae-Cree - in old Irish, Hill of My Heart (Plate 168), and the curtailed view of the flowery planting in the Woodside garden stimulate a longing further to penetrate into these lovely sanctums.

The garden at Elmwood is partly illustrated in the accompanying picture - it is further gracefully adorned with pergola and pool. Liberally designed without being elaborate, it has a charm that is all its own.

Of quite another character is the perfect formal garden at Pomfret Center, appealing to the garden lover for its surpassing beauty in flower bloom, enhanced by the graceful architectural lines of the buildings surrounding the enclosure, and giving it the sense of complete privacy.

Still another type of garden seen occasionally in America is that at Branford House, a magnificent estate at Groton near New London, and one of the famous places of that popular summer resort. This stately garden suggests some of the foreign gardens familiar to us through travel and books. 


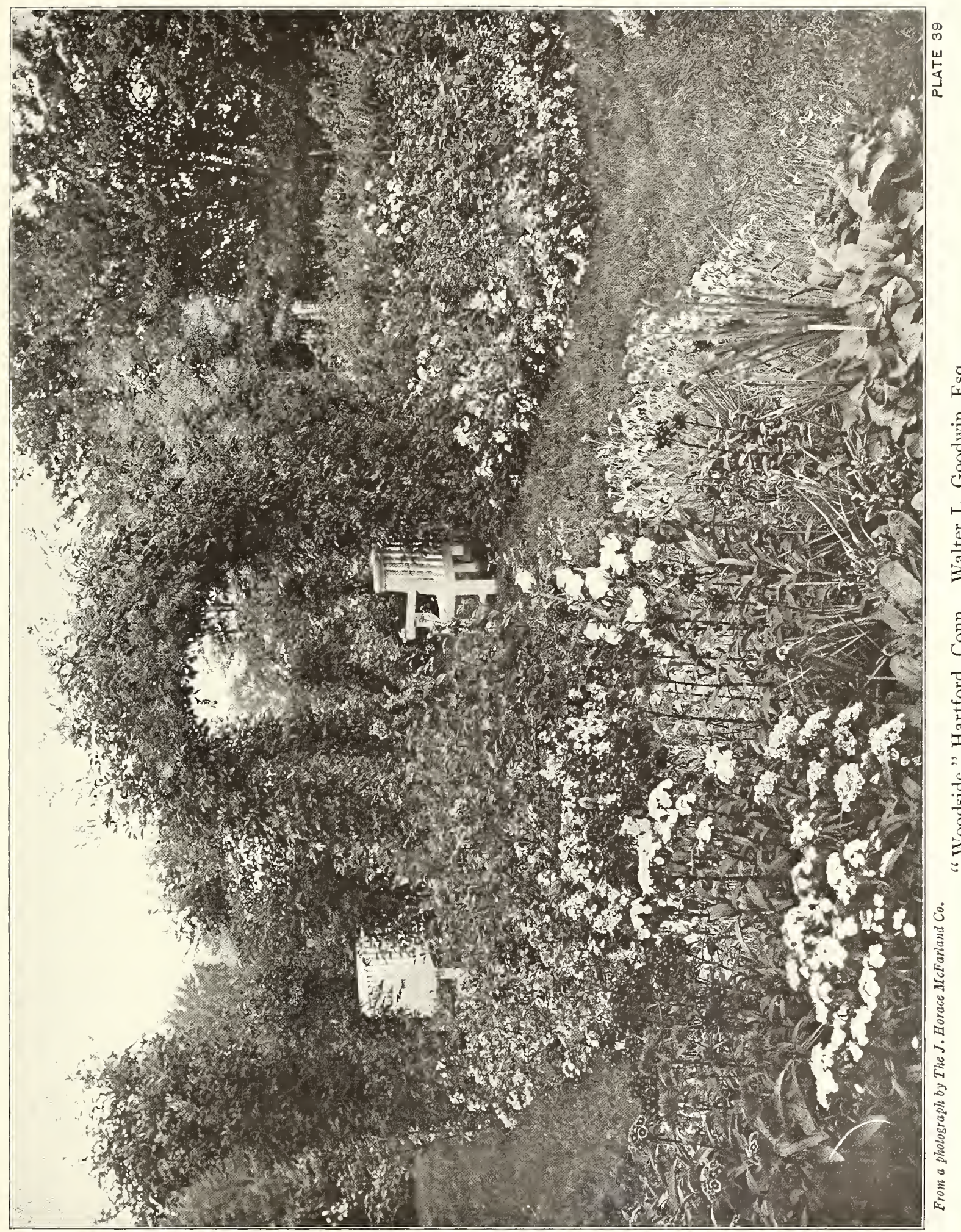





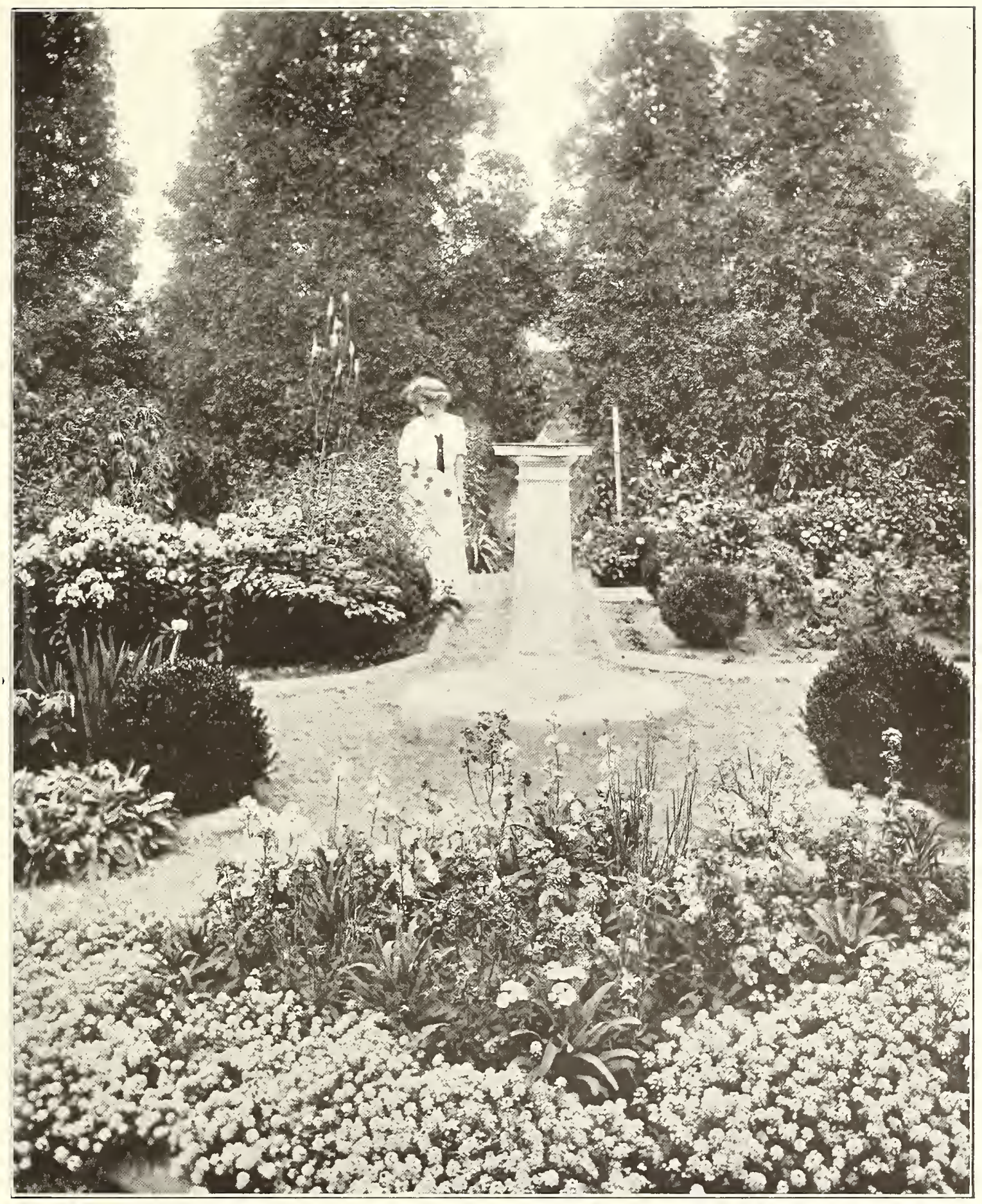

From a photograph by Miss E. M. Boull

PLATE 40

"Elmwood," Pomfret, Conn. Vinton Freedley, Esq. 



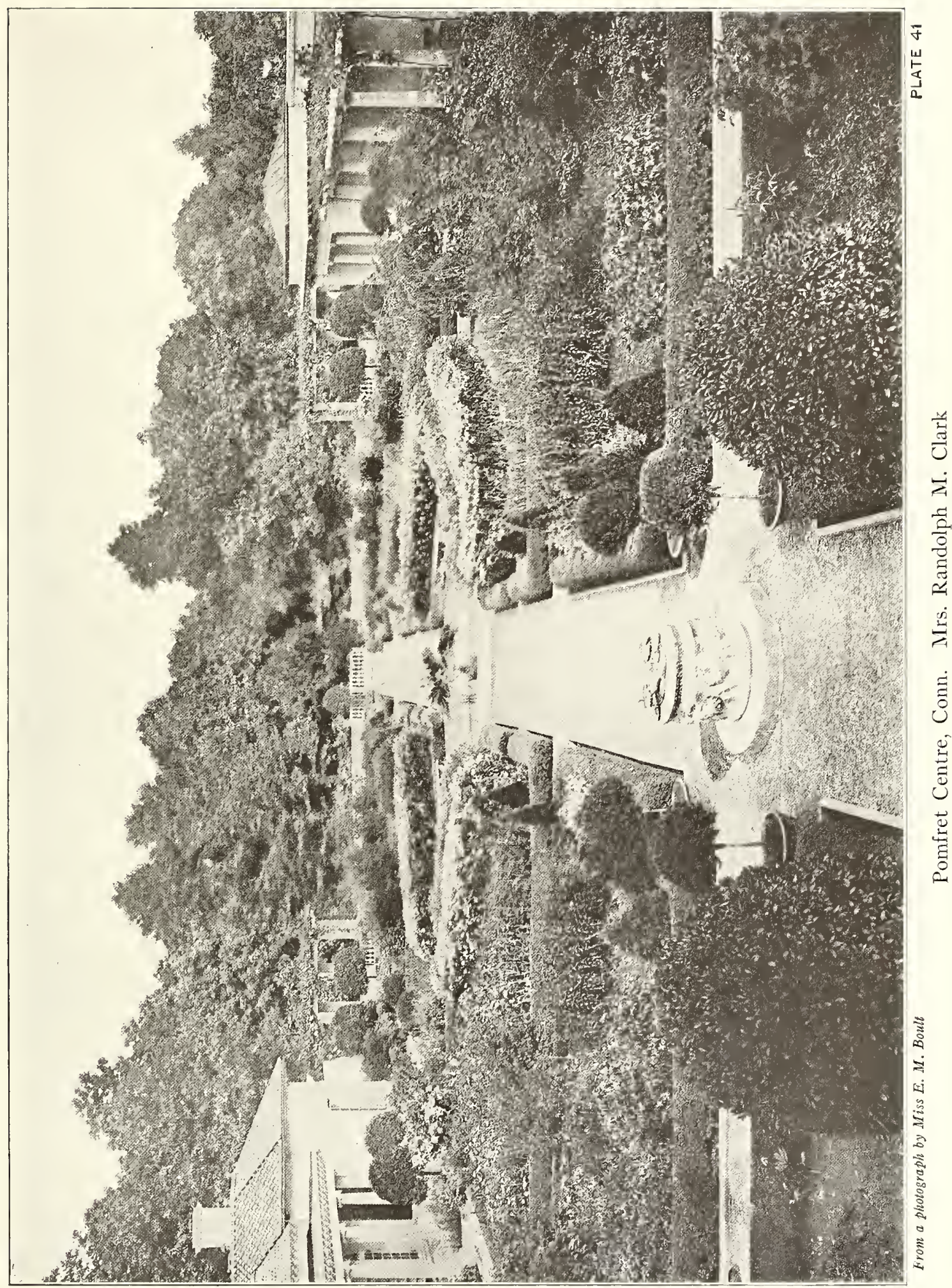





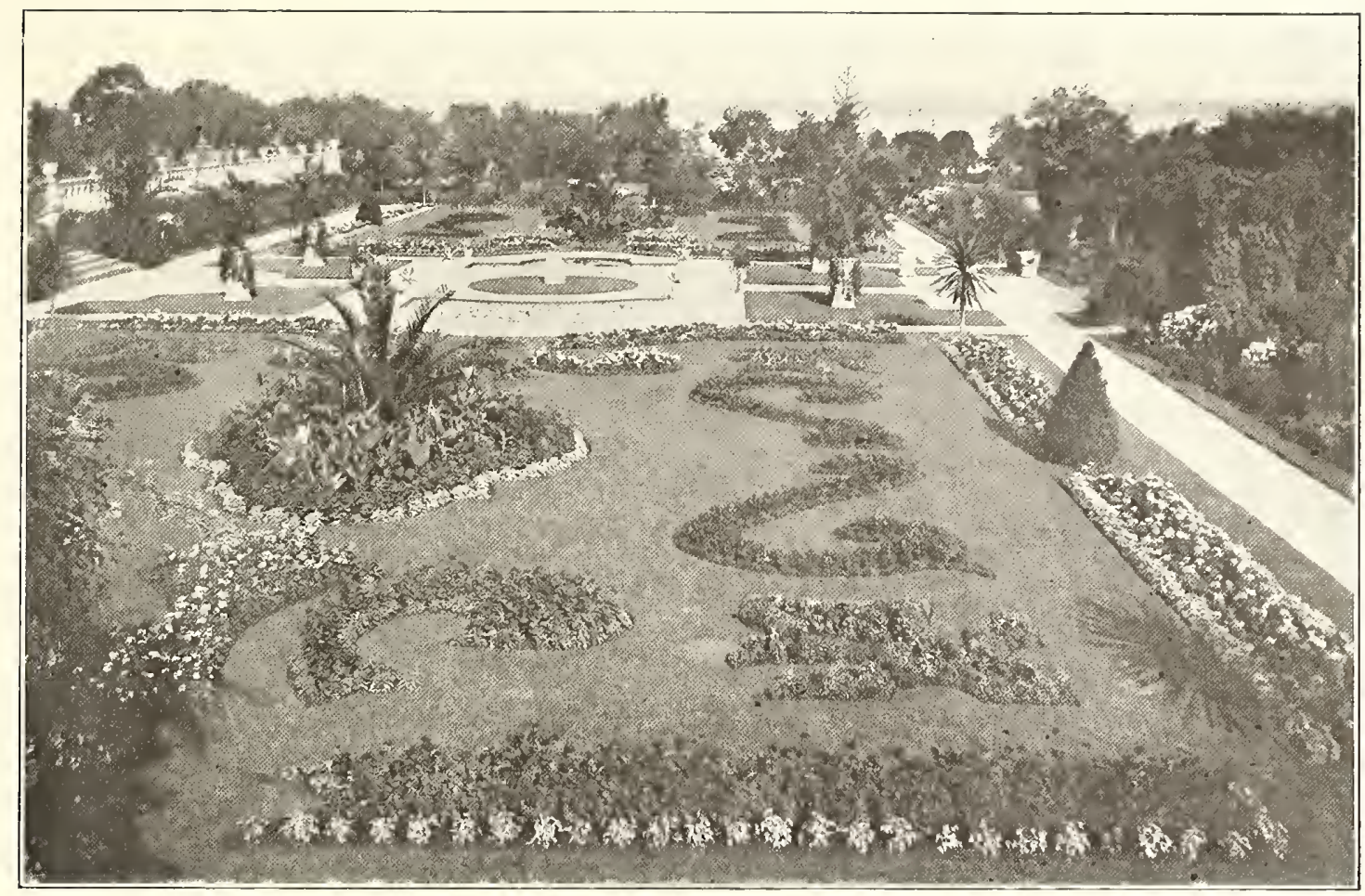

PLATE 42

"Branford House," Groton, Conn. Morton F. Plant, Esq.

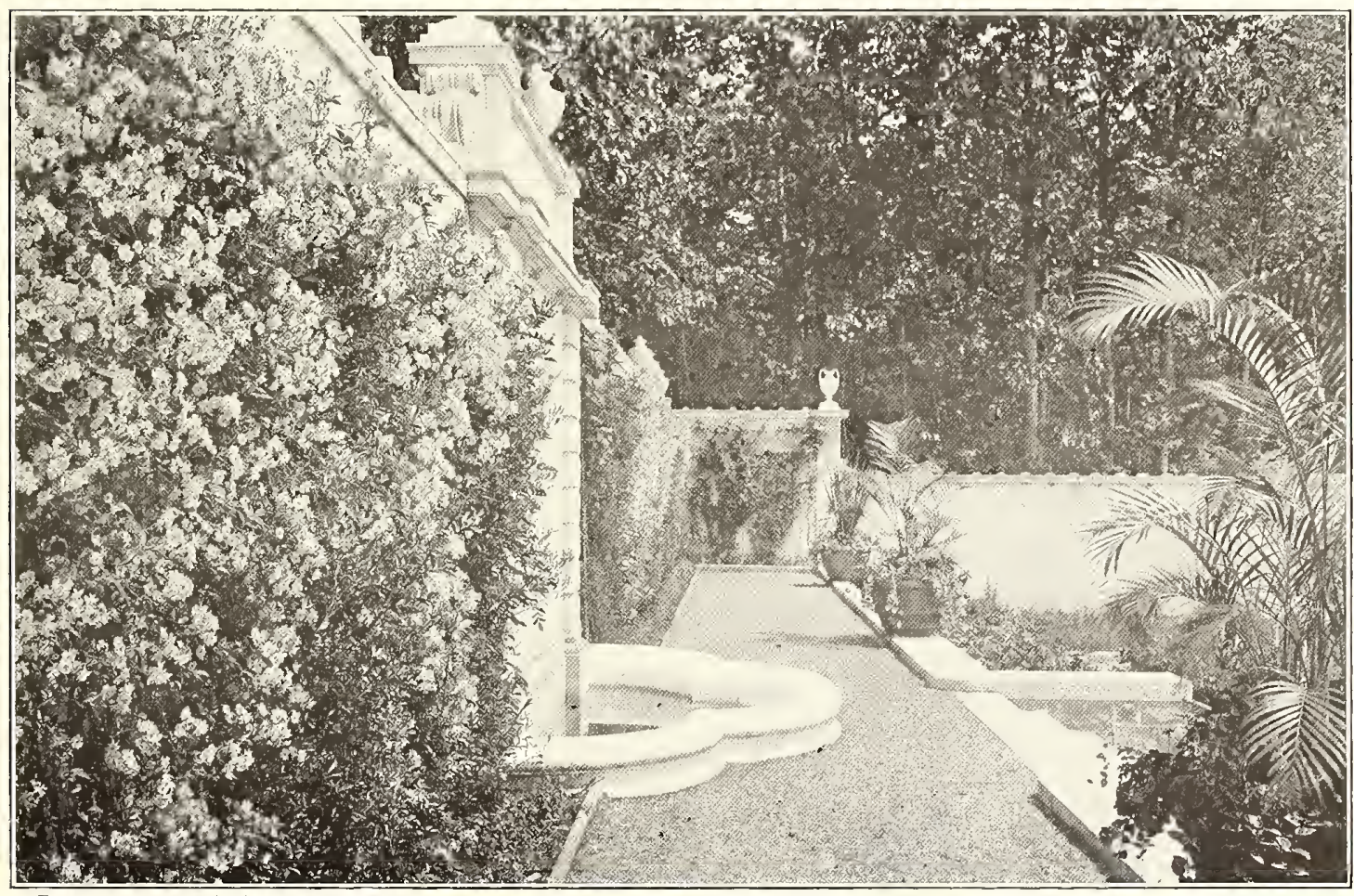

From a photograph by Miss E. M. Boult

PLATE 43

Pomfret Centre, Conn. Mrs. Randolph M. Clark 



\section{IV}

\section{NEW YORK}

There are gardens, old and new, around the many wealthy cities of this great State, through the upper section, near Buffalo, Utica, Syracuse, Albany, etc., as well as to the south. It must suffice to give a few of the most picturesque views obtainable, almost all of which belong to places within one hundred miles of New York City.

The garden at Auburn offers a vision of flowers in glorious profusion, combined with perfect order, which latter condition is not always easily attainable when plants are allowed a certain amount of freedom. The location of this garden, in western New York not far from Lake Ontario, is in about the latitude of northern Massachusetts - a climate congenial to flowers.

A particular type of garden often predominates in some localities on account of the conformation of the land; as, for instance, in a mountainous section like Tuxedo Park, where the places are scattered over hilly woodland country, many of the gardens naturally develop into those of terraces, or else ideal opportunities have created the rambling wild garden with winding paths, shaded pools, ferns and flowers. A glimpse of one of this kind is to be had in 


\section{BEAUTIFUL GARDENS IN AMERICA}

an accompanying illustration - an exquisite bit of semicultivated wildness that moves one to wish to see beyond the picture's limits.

Among its formal gardens, Tuxedo at present has nothing more imposing than the one at Woodland. The wall-beds contain perennials in mass against the vineclad background, and the central fountain is framed in broad beds of Roses, in bush and standard form. This garden's stately effects are enhanced by the richly developed forms of clipped evergreens in Boxwood and various Retinosporas, to all of which age, as must ever be the case, lends force and dignity.

The Cragswerthe garden, a spacious plan on three connecting terraces, charmingly exemplifies the results obtainable by the exercise of good taste upon desirable opportunities. Each terrace illustrates, in harmony with the whole, a special beauty of its own.

The hill gardens usually have also the advantage of a landscape background, as a rule a pleasant feature also in the Mount Kisco region of Westchester County, with its numerous hilltop homes. A garden with a view possesses a setting all its own; one that can hardly be imitated in that particular landscape at least, varying under the changing clouds, and therefore never monotonous. Such also is the opportunity in many Hudson River places, and only those who have lived in the highlands by this most beautiful of American rivers know the charm of the mountainsides, with their deep ravines and river vistas. 


\section{BEAUTIFUL GARDENS IN AMERICA}

There is space for but a few of the river gardens in these limited pages. The one at Blithewood, Barrytown-onHudson, is a charming example of a more modern garden, beautifully located and planted especially for May, June, and September. A vine-covered brick wall surrounds it on three sides, and a terra-cotta balustrade is the boundary on the river side. Chinese Junipers, not supposedly very hardy, are, however, the well-grown, clipped evergreens in sight. Barrytown is about a hundred miles from New York.

Up on the Beacon Mountain the Wodenethe gardens were begun about seventy-five years ago, remaining ever since in the same family, and always celebrated for their beauty, due doubtless to the devoted and skilful care continuously given them. Trees, shrubs, and vines are rich in maturity; the impress of Father Time has so kindly marked the place, that of the older gardens Wodenethe is probably the finest on the Hudson.

Not far away there was once another garden. Possibly there is nothing fairer than the dearest memories of childhood - sometimes doubtless wonderfully interwoven with the gossamer-like stuff of which air-castles are made and so it is with deep satisfaction that the author can dwell upon views of an old garden relying on something more real than semi-dreams. To be able to duplicate this happy place for some other fortunate children would be a joy indeed, and some day the opportunity may be realized while the dream still lives. Nearly three acres of land 


\section{BEAUTIFUL GARDENS IN AMERICA}

might be required to contain the broad beds bordered with peach, plum, pear trees and shrubs, and edged with flowers - the great centre spaces filled with vegetables or small fruits. The outer court of this garden, on three sides, was formed by two rows of arching apple trees, as shown in an accompanying illustration. The fourth side was a lane running between an evergreen hedge and a line of Poplar and nut trees. The outer walks were broad, the inner intersecting paths were narrower; the tall planting in the various beds prevented a view from one path to another, and this was half of the garden's fascination to the children who played there in the games of make-believe. Always there was something unexpected awaiting them around the corner. Blissful the chance to become suddenly lost in grape vines, corn, or dense shrubbery when the world seemed to consist of just tree-tops, sunlight, flowers, fruits, and birds! What a contrast to the life of the average fortune-favored child of the present period!

Echo Lawn is another lovely place near the river, as old, too, as Wodenethe, extensive in acres, abounding in splendid trees, and full of a beauty and charm peculiarly characteristic of the old places on the Hudson. The gardens, although of a later-date creation, are admirably fitted to the surroundings, and with pools, wall basins, and flower planting, hardly discernible in the illustration, are a rich addition to the noted river places.

Twenty miles to the west of the Hudson River is Meadowburn Farm - famous through its owner, the 


\section{BEAUTIFUL GARDENS IN AMERICA}

author of "Hardy Garden" books. Two photographs, not hitherto published, must alone represent the acres of bloom on this interesting place. In describing it, eight gardens must be considered rather than the garden. The Evergreen Garden (shown here), the May Flowering Hillside, the Lily and Iris Garden, the Pool Garden, the Perennial Garden, the Cedar Walk, the Vegetable Garden, bordered with flowers, and the Rose Garden. A rare treat for garden lovers who visit there by special arrangement.

At Ridgeland Farm, in Westchester County, the owner has shown that the smallest garden possible when fitted to artistic surroundings and filled with harmonious bloom can, as a garden and as a picture, satisfy our craving for the beautiful quite as completely as a subject on a much larger scale. This fair little plot, with its brick paths and gay blossoms, continues in bloom for several months, which, in spite of narrow beds, is always possible in a well-planned and carefully tended garden.

New York includes within its borders the climate of all the New England States, and, besides, the atmosphere of its lake shores and the milder sea climate of New York City and Long Island. Between the high altitudes of the Adirondacks on the north and the sea-level of Long Island on the south there is a difference of nearly four weeks in the opening of spring. Within a forty-mile radius of New York City and westward in the same latitude Daffodils appear about April 15; early Tulips and Phlox divaricata 


\section{BEAUTIFUL GARDENS IN AMERICA}

the last of April; late Tulips May 10; Lilies-of-the-Valley May 15; German Iris May 22 (florentina alba a trifle earlier); and by May 25 Lupins, Columbine, Pyrethrum hybrid, and Oriental Poppies, etc., arrive; Roses, Peonies, etc., about June 1; Sweet William, Anchusa, and their companions June 5; Campanula medium June 15; Delphinium June 20; Hollyhocks July 1 or a few days earlier. At the eastern end of Long Island Tulips, Lily-of-theValley, Roses, shrubs and tree foliage appear about a week later than the same near the city of New York. In our extremely variable climate it is impossible to have fixed dates for the opening of bloom. It must depend upon whether spring is early or late, which sometimes causes a difference of a week or ten days in the appearance of the flowers. Lily-of-the-Valley and German Iris seem less affected by variable springs than other plants. It is perfectly safe near Manhattan Island to plant out tender annuals May 25, and many venture it by May 15. Killing frost may be expected between October 1 and November 1 - rarely earlier than October 1 .

Forty-five miles north of the city of New York, in such higher altitudes as Mount Kisco or Tuxedo Park, the spring opens about a week later. Within this radius of the city the summer thermometer occasionally rises above seventy-eight degrees, and in winter it may average possibly thirty to forty degrees above zero; only a few days know zero weather, and rarely does it drop below. At least once a winter there will come a period of weather as mild 


\section{BEAUTIFUL GARDENS IN AMERICA}

as fifty to sixty degrees, when one almost fears the premature appearance of some of the plants. It is on account of the thaws as well as the cold that the plants require a moderate covering to keep the ground as far as possible frozen hard and undisturbed by the sun, as frequent thawing injures the roots.

A garden at the other extreme of the State, in the Adirondack Mountains, planted to begin with early Tulips, Phlox divaricata, and others of this period, will make its display about June 1. Lilies-of-the-Valley arrive soon after June 8; German Iris, Lupin, Pyrethrum, Oriental Poppy about June 15; Sweet William and Roses near July 1; Delphinium July 15; Hollyhocks July 25. Tender annuals are planted out about June 10 , and a frost after that date is of rare occurrence. The first killing frost of autumn may be expected between the 15th and 20th of September. While the thermometer in summer fluctuates between sixty and eighty degrees, it often falls in winter to thirty degrees below zero. The hardy plants are well protected under the heavy snow covering which is usually the winter condition there. 



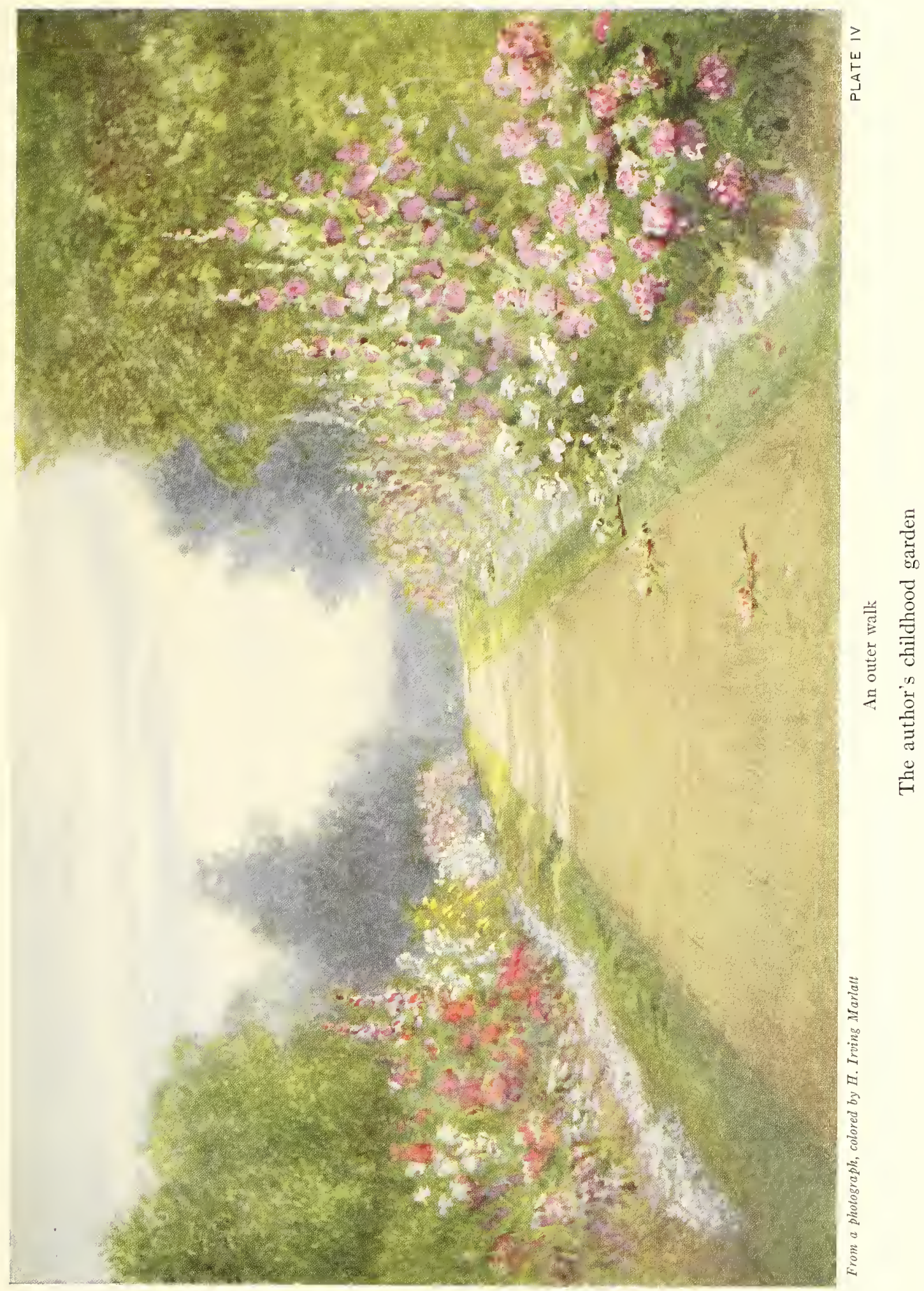





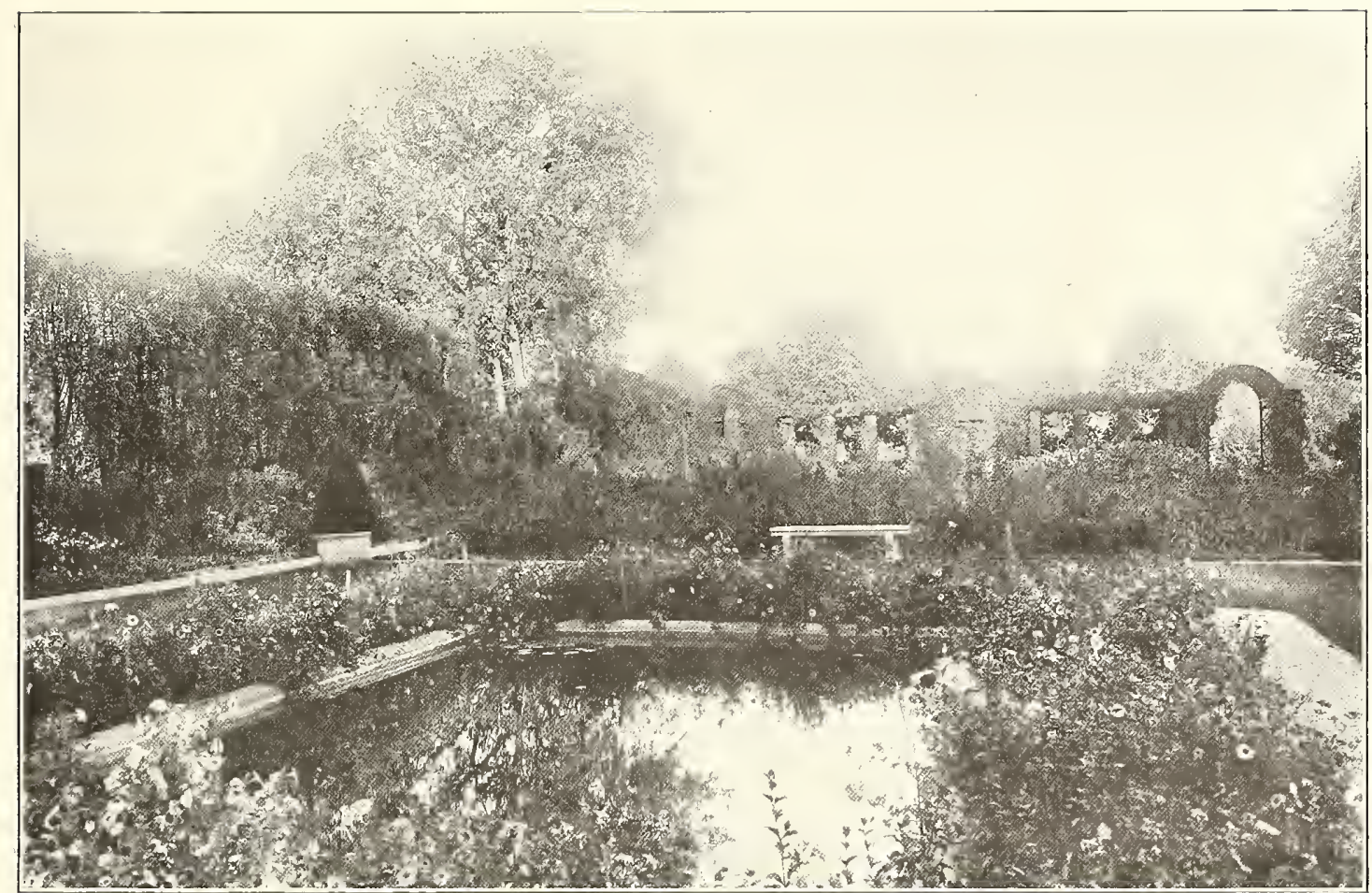

Auburn, N. Y. Mrs. C. D. MacDougall

PLATE 44

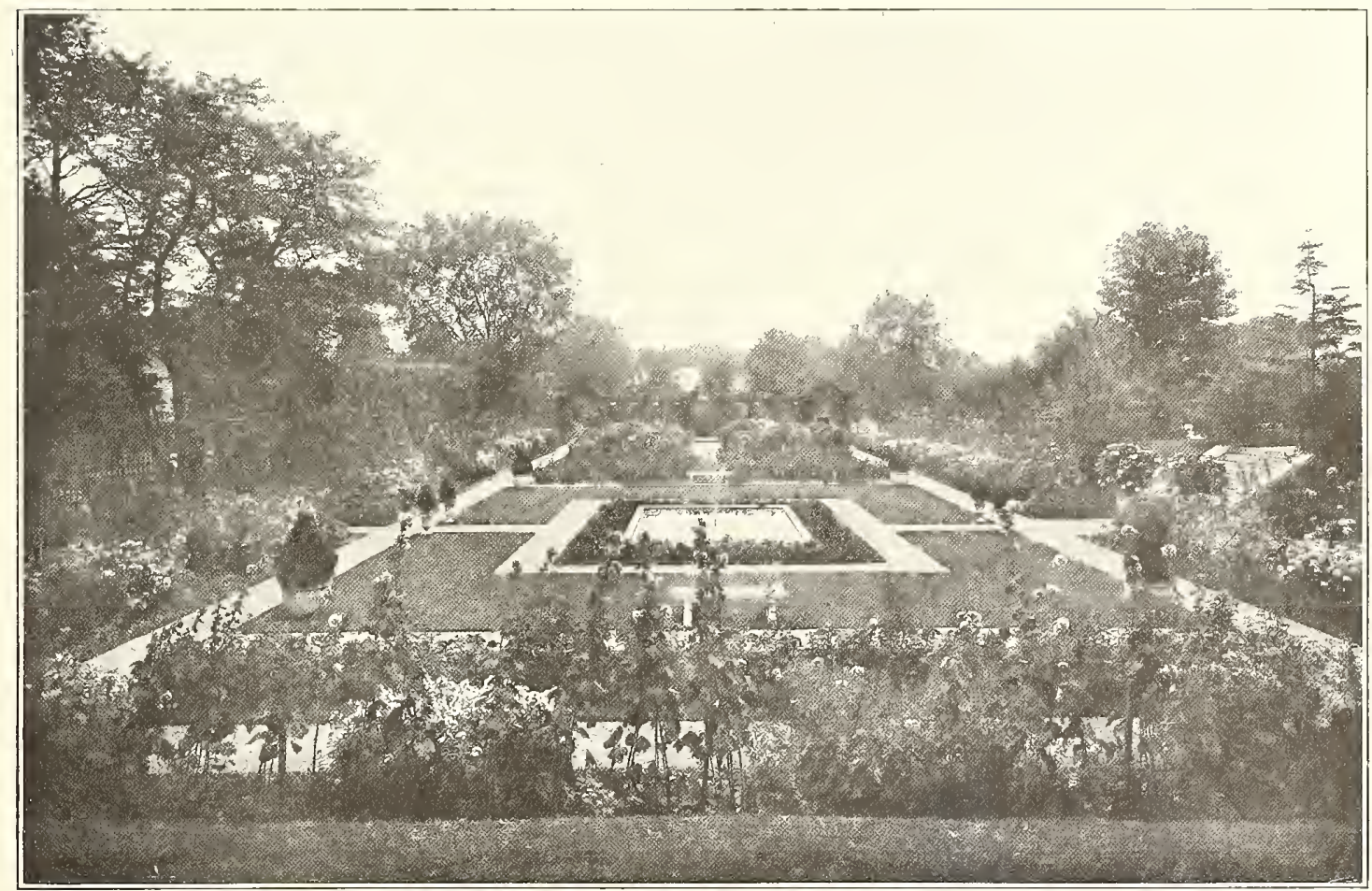

From photographs by Emil J. Kraemer, by couresy of Wadley \&o Smythe

PLATE 45

Auburn, N. Y. Mrs. C. D. MacDougall 



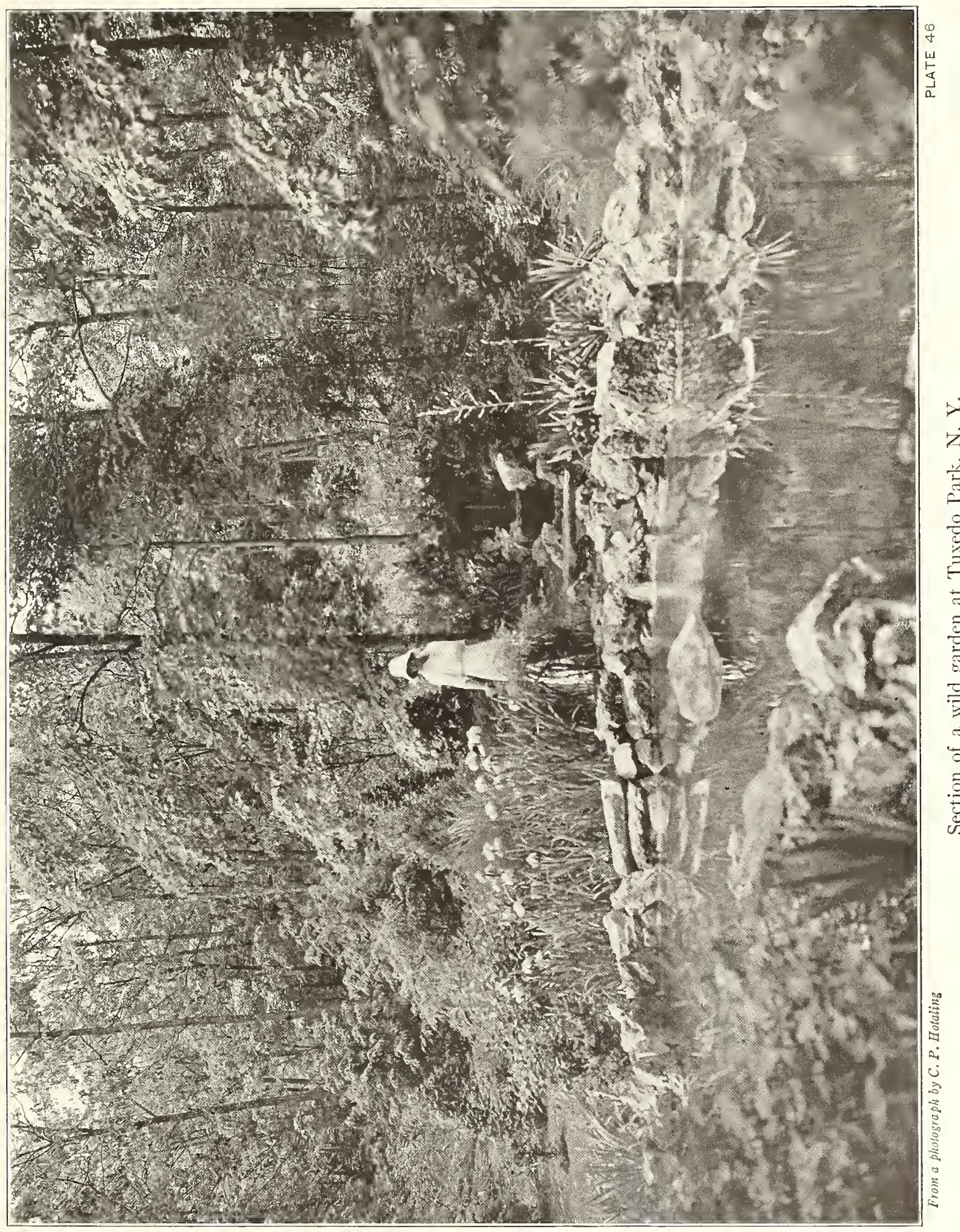





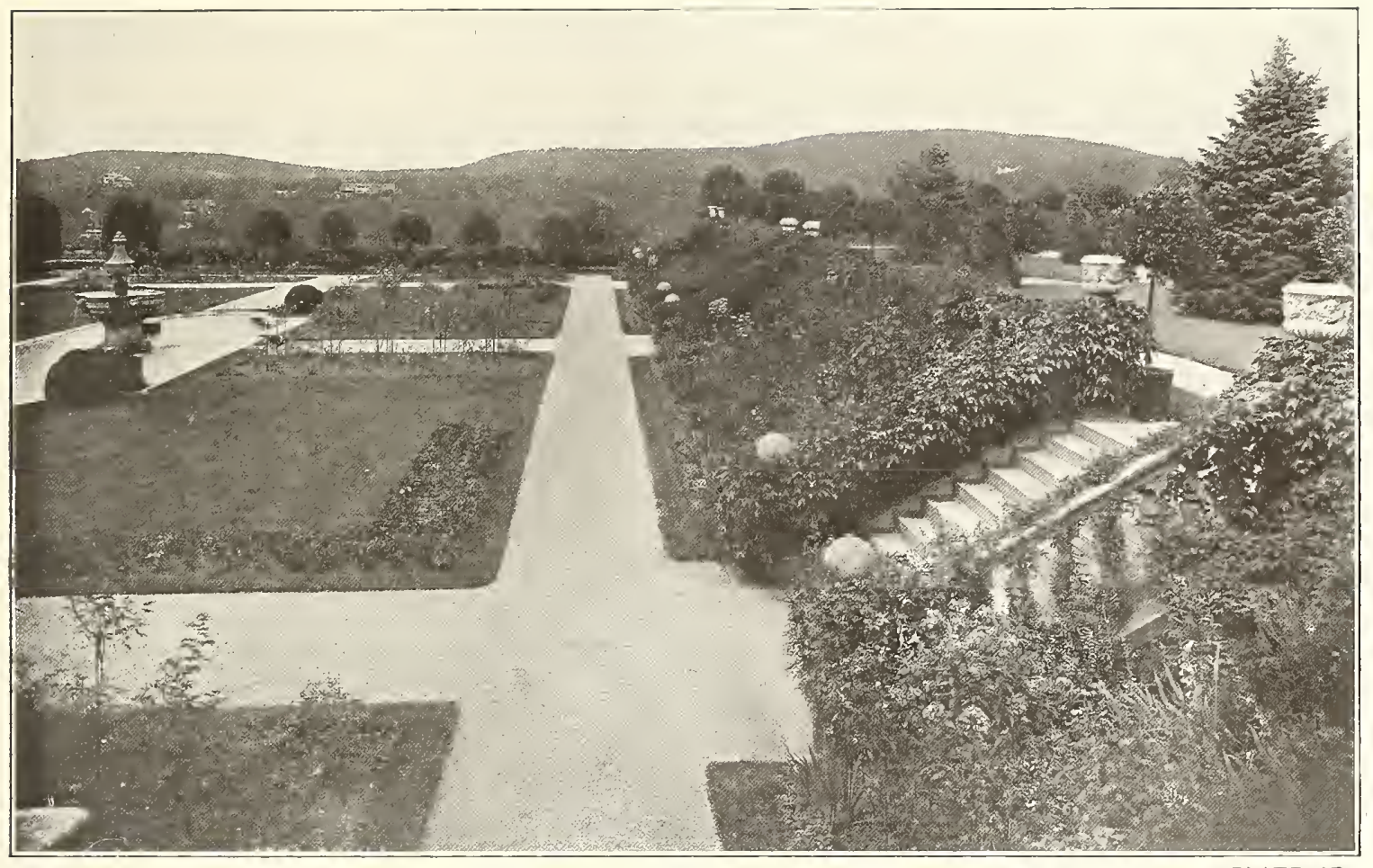

"Woodland," Tuxedo, N. Y. Henry L. Tilford, Esq.

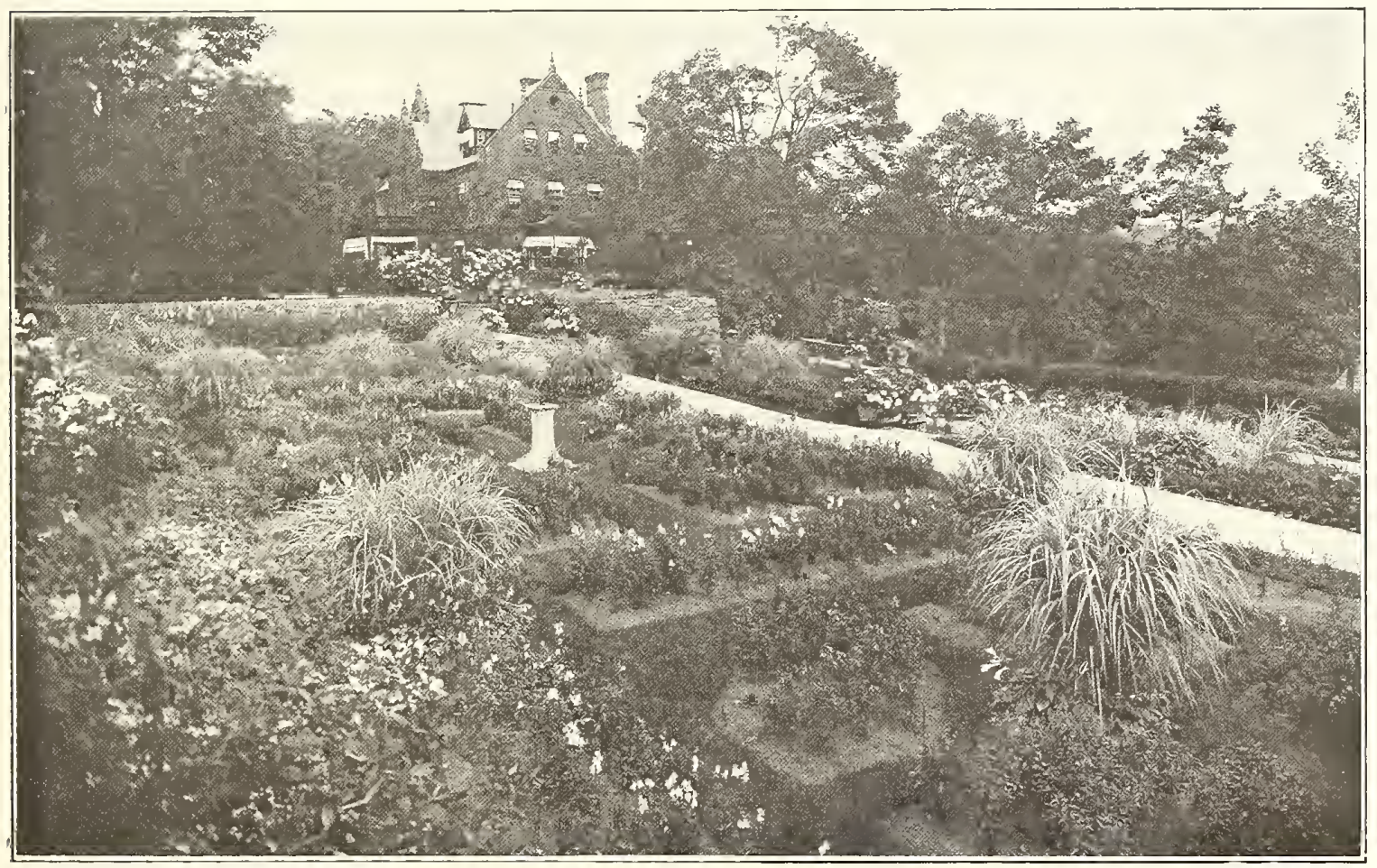

From photographs by Jessie Tarbox Beals

A garden in three terraces

PLATE 48

"Cragswerthe," Tuxedo, N. Y. Mrs. Samuel Spencer 



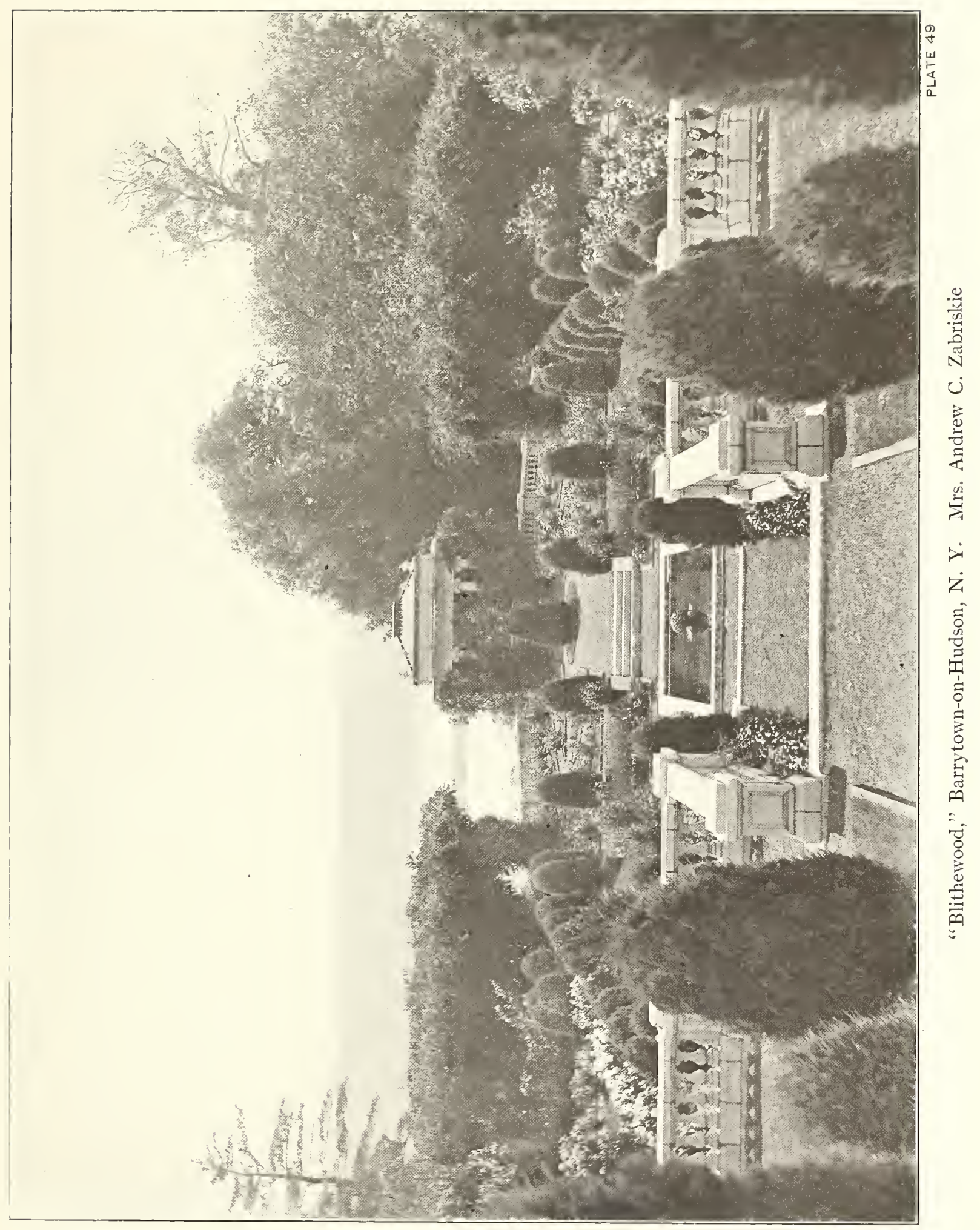


, 


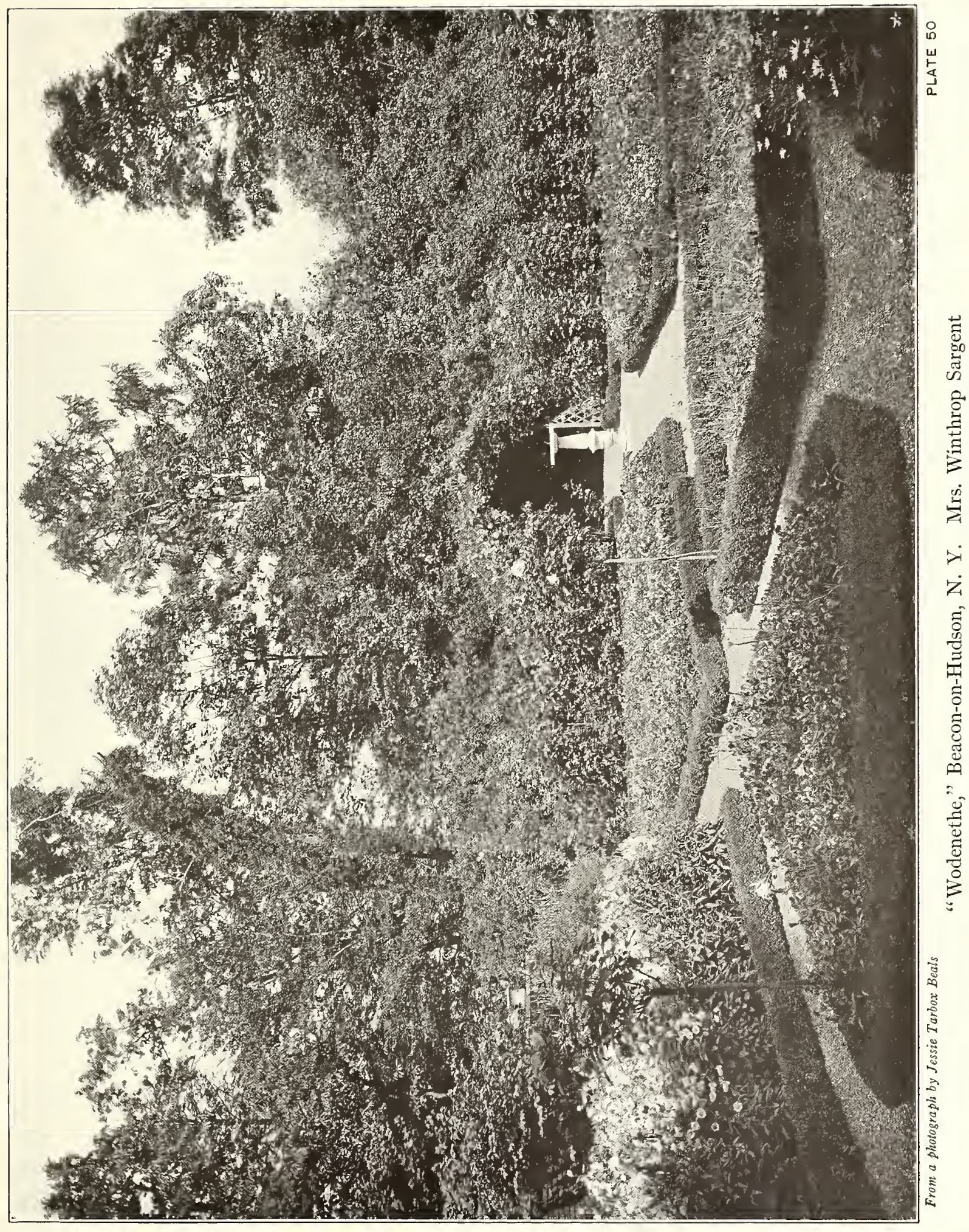





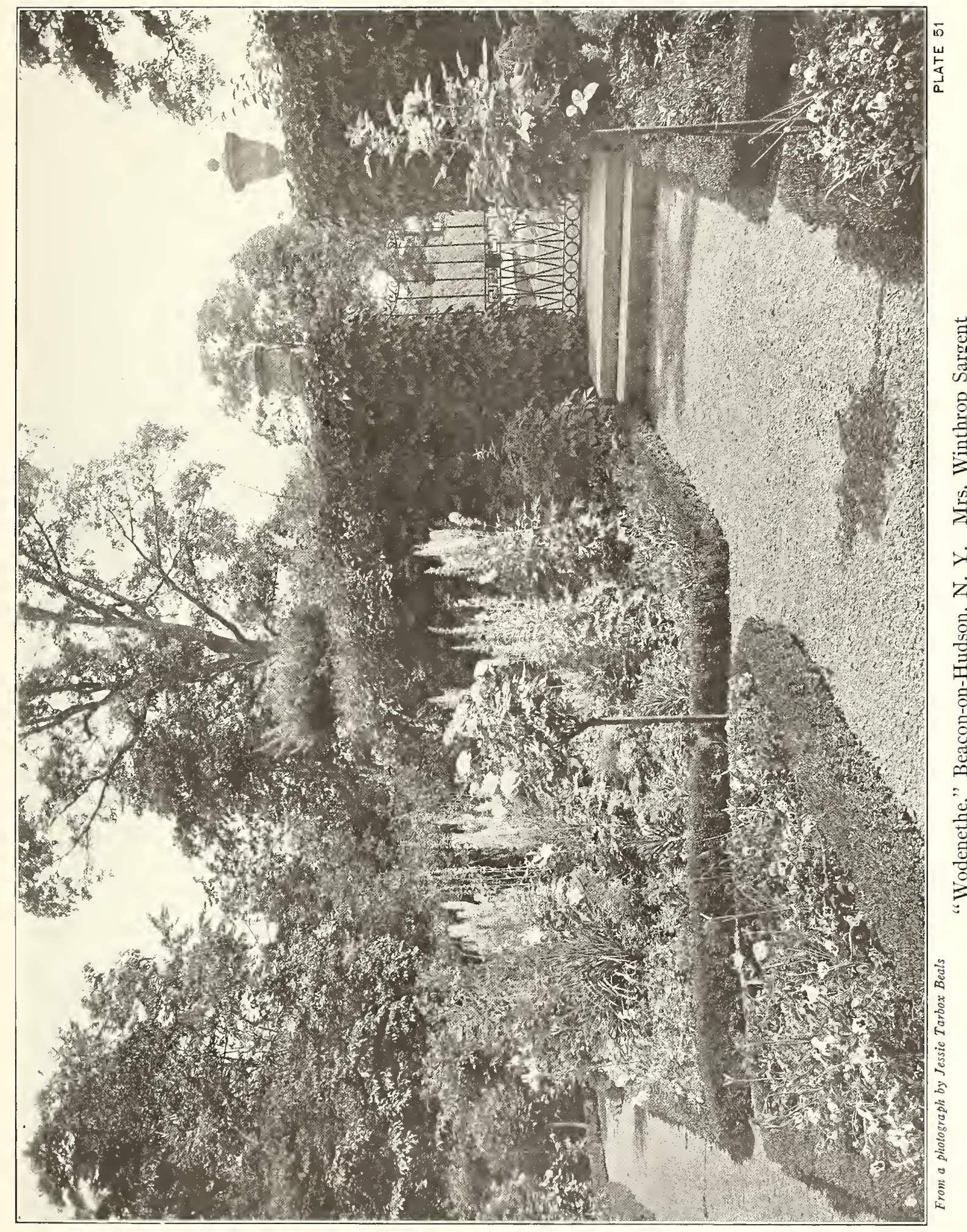





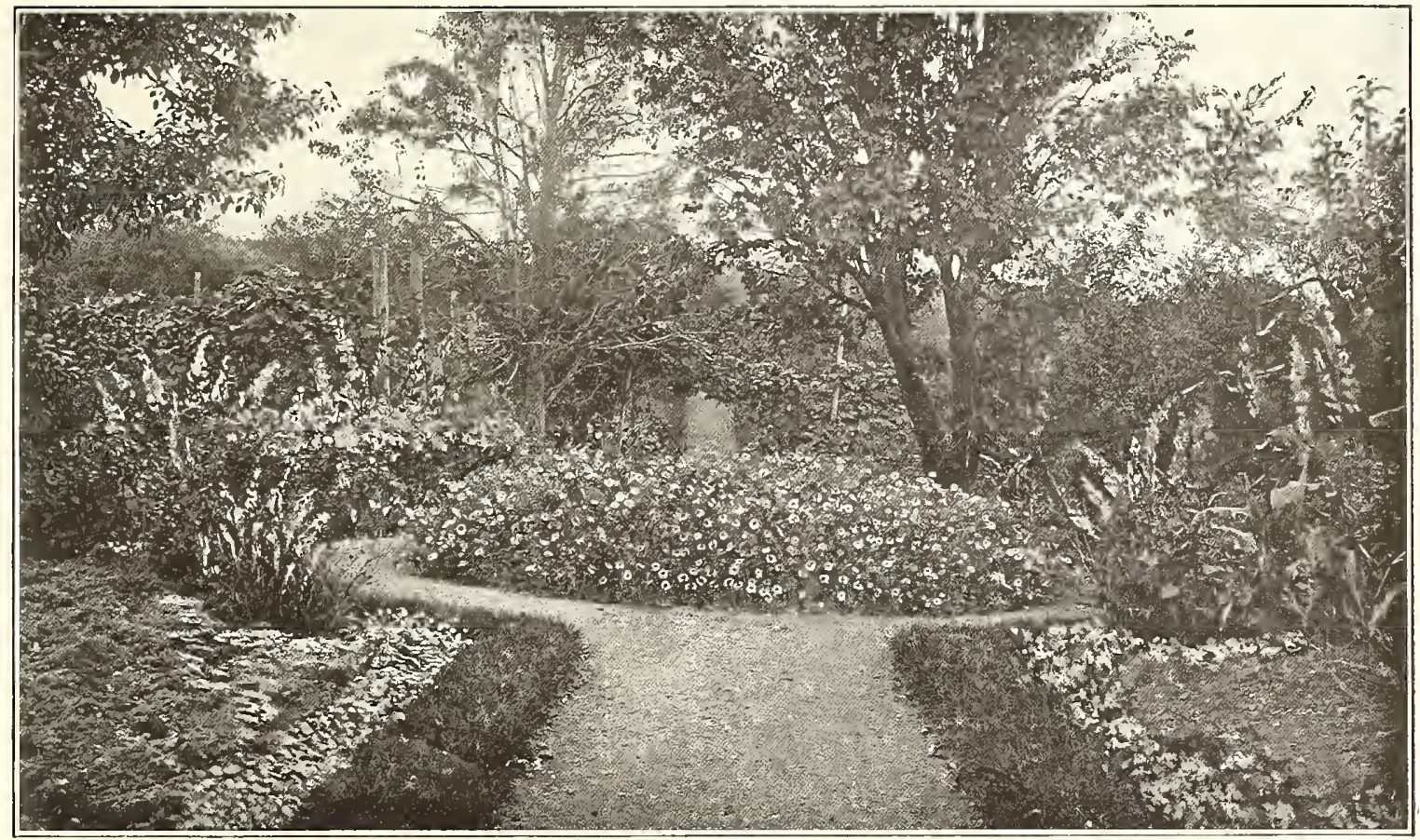

The centre section

PLATE 52

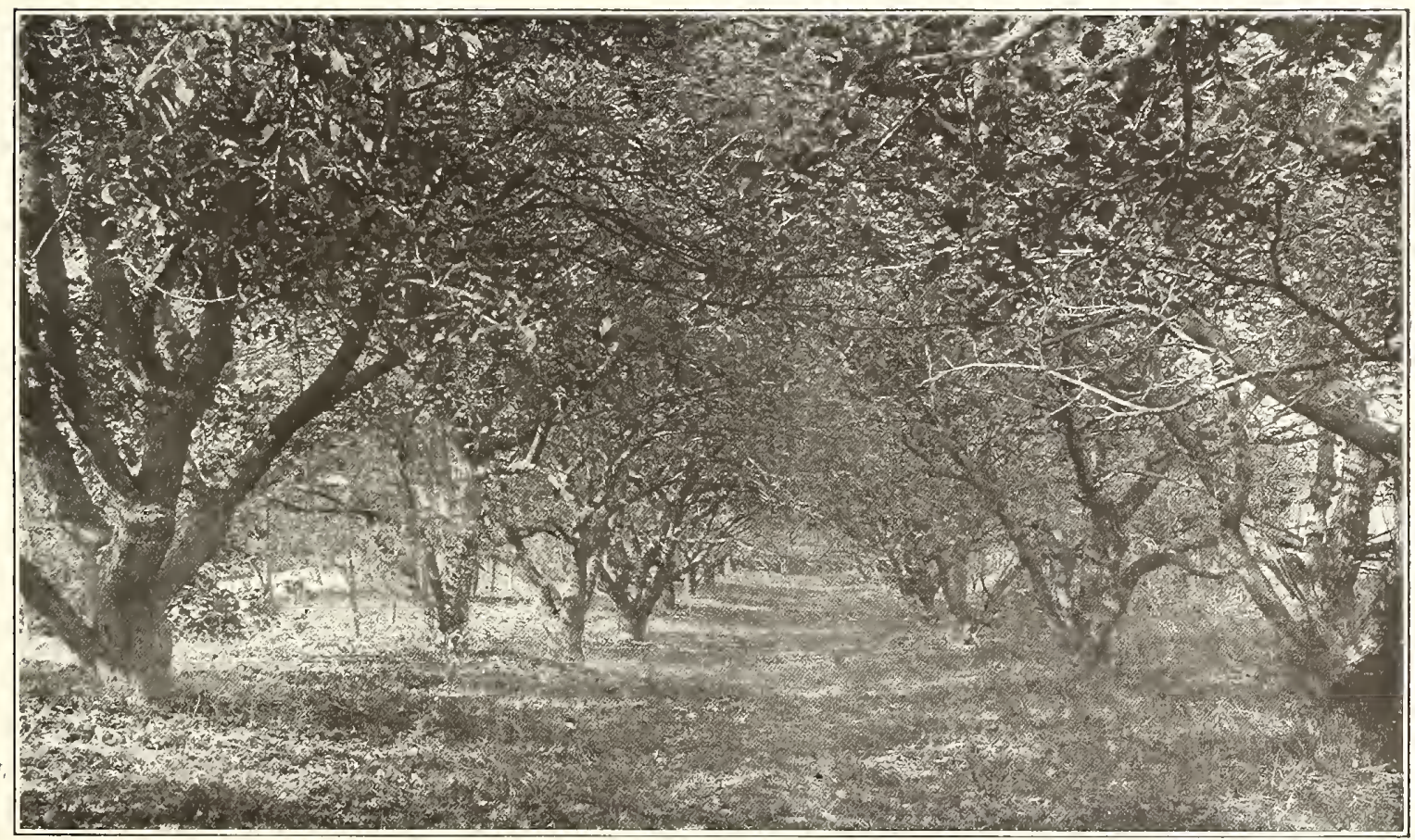

The outer boundary

PLATE 53

The author's childhood garden, Newburgh-on-Hudson, N. Y. 



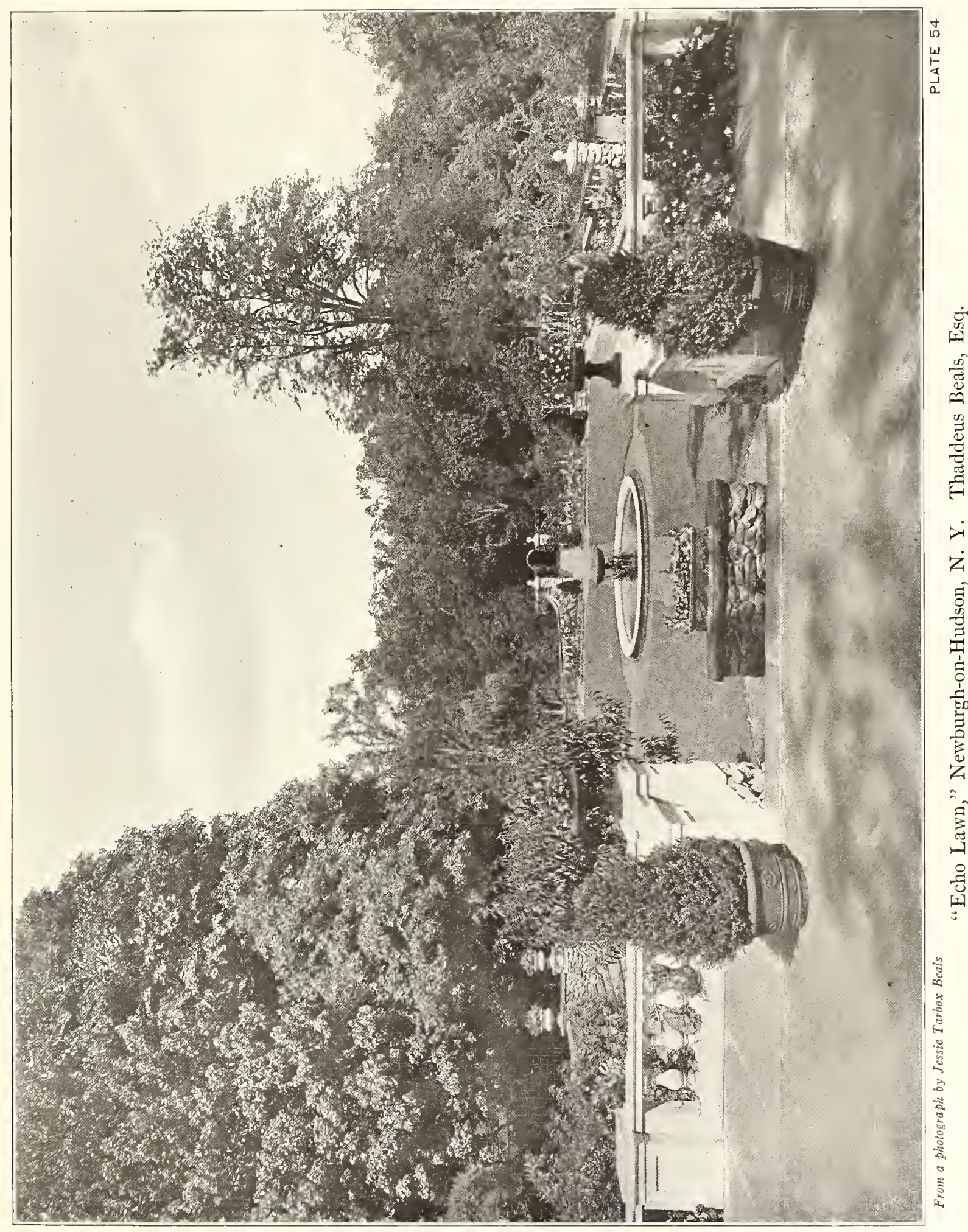





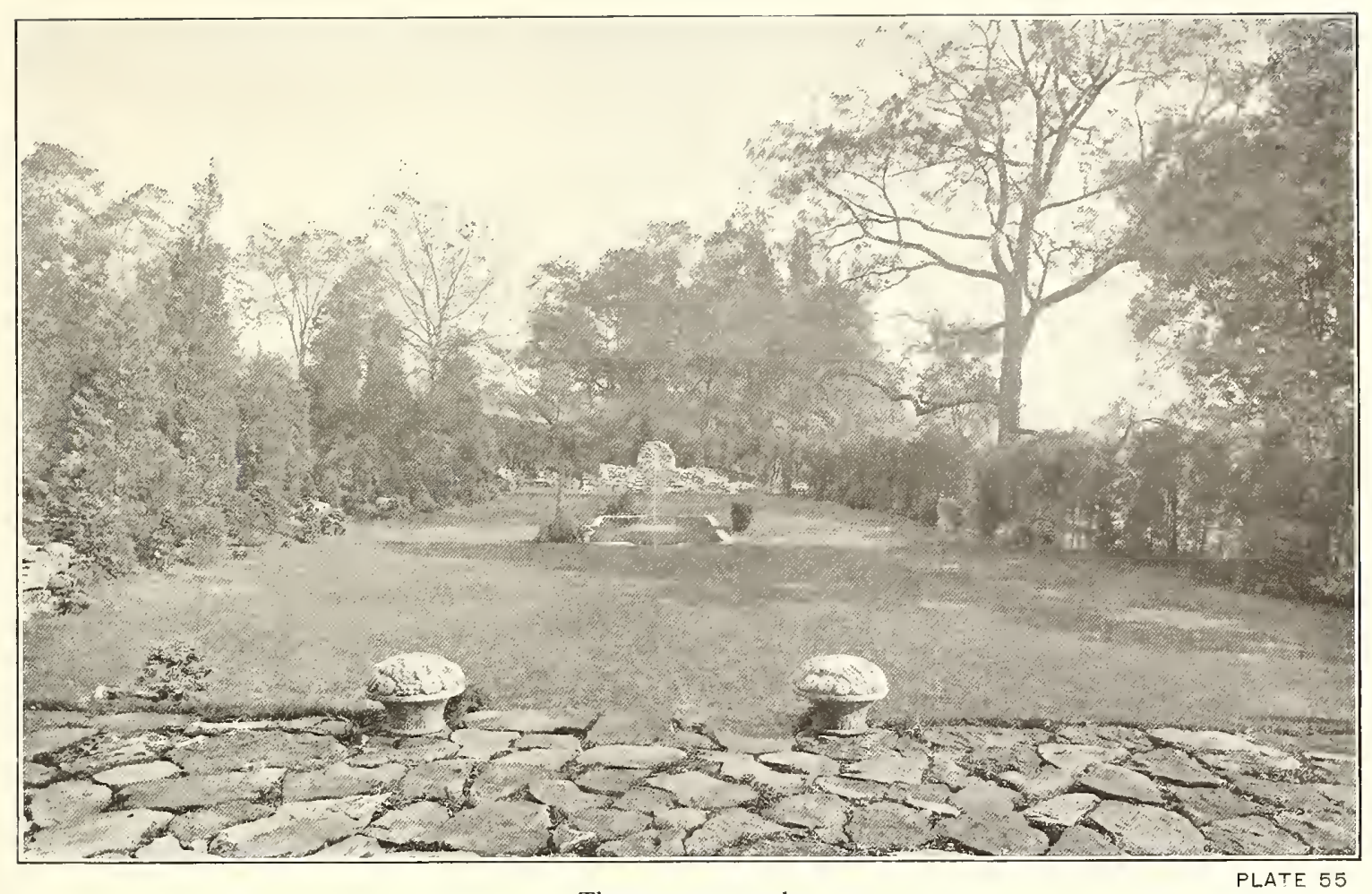

The evergreen garden

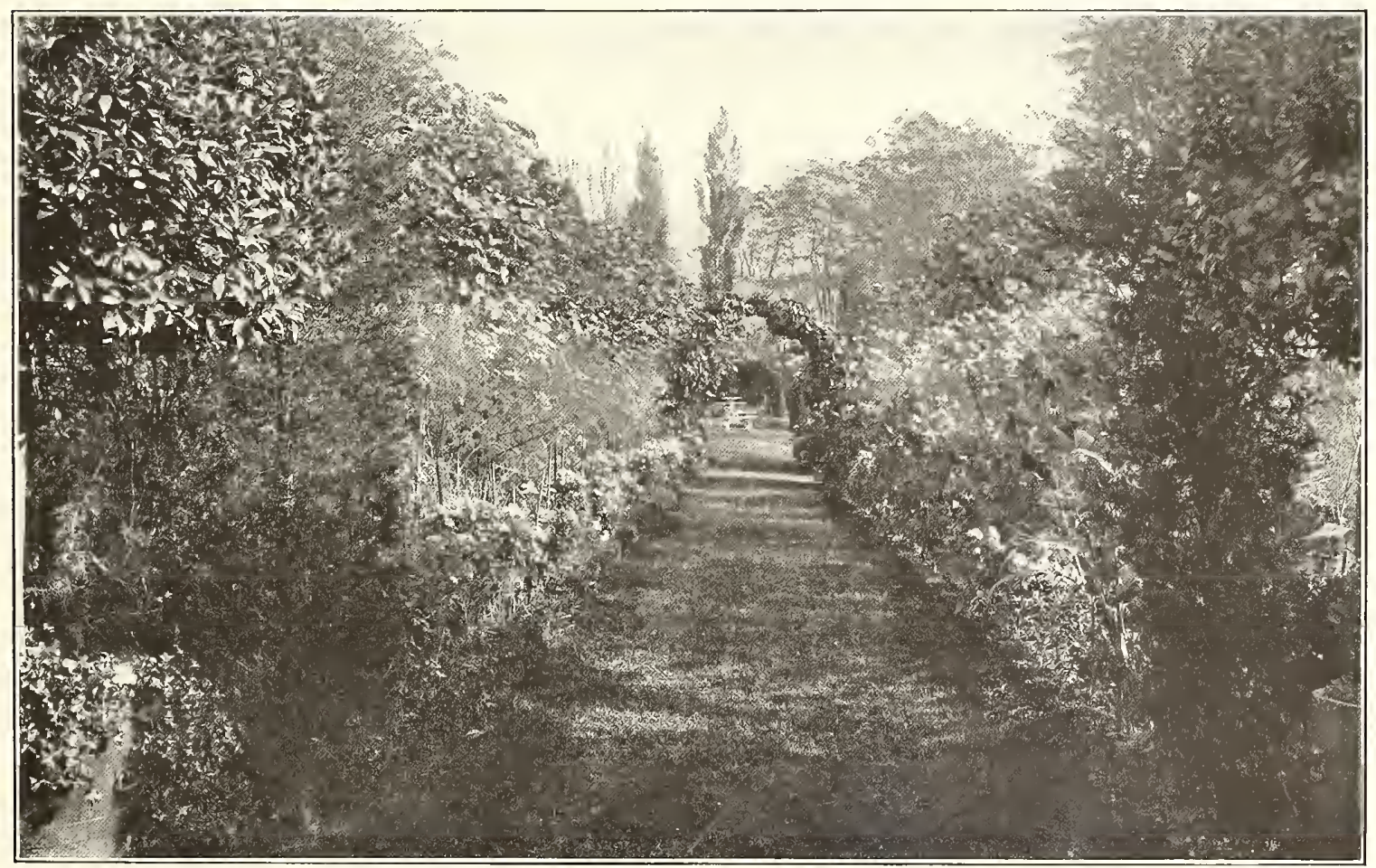

A path in the perennial garden

PLATE 56

"Meadowburn," Warwick, N. Y. Mrs. Helen Rutherfurd Ely 



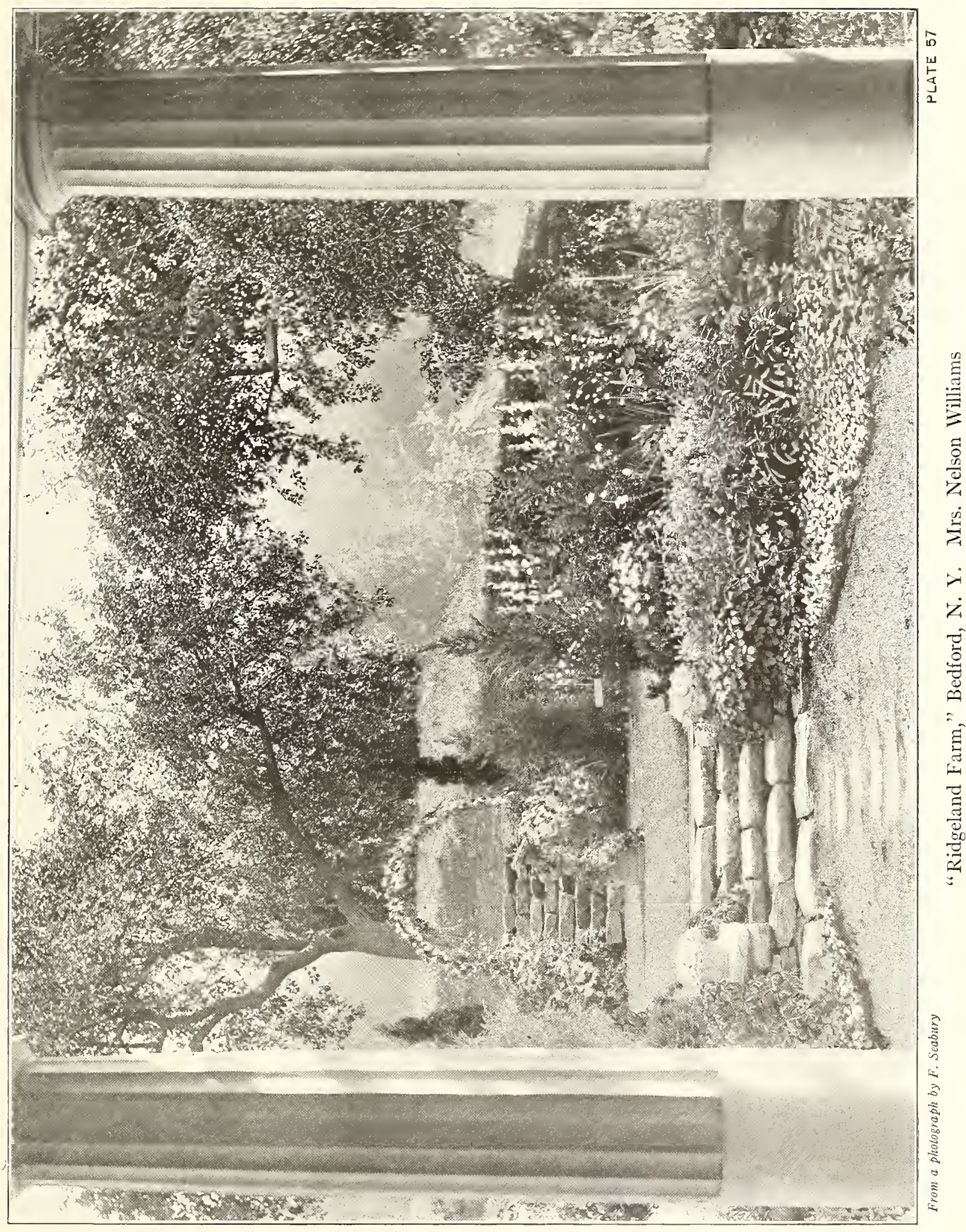





\section{LONG ISLAND, NEW YORK}

In considering the gardens belonging to the State of New York, its most favored garden centre is undoubtedly Long Island. Here soil and climate combine to encourage both vegetables and flowers. And on the shores, particularly of the south side and eastern end, the most satisfactory bloom is obtainable as a rule with less trouble than is expended upon the flowers of the interior. Not that Long Island is secure from periods of drought and visitations of rose-bugs, but on the whole the plants weather the obstacles better here than in other places of this latitude. There is a marked softness in the winter climate especially near the sea. Possibly nowhere else except in southern California does the Privet hedge make as remarkable growth as on the south shore, and near the west end there are highly prized specimens of old Box. Southampton, at the eastern end, in proportion to population has probably a greater number of gardens than any town in the State, almost all of them designed and developed by their owners, who have thus delightfully expressed their love for flowers.

Most soul-satisfying, unique in many points, and overflowing with bloom all summer is Mrs. Wyckoff's garden at Southampton. Within three hundred yards of the beach it is truly a seaside garden, but the great Privet hedges, fourteen feet high, make perfect windbreaks for the protection of its bloom. Connected by arched openings in the Privet there are other enclosures for various 


\section{BEAUTIFUL GARDENS IN AMERICA}

planting schemes, and noticeable is the rather unusual variety of flowers growing in these several lovely gardens. The color grouping in the long, broad beds against the tall Privet background is as perfect as any planting known. The arbors on either side of the garden proper are formed of arches of Dorothy Perkins and Cedar trees alternating the Cedars are bent and strapped at the top to produce a curve. The effect is both unusual and delightful.

In the same place but farther from the sea is another famous garden, at The Orchard, the estate of James L. Breese, Esq. The garden was started about 1905 and is entirely original in design. The artistic sense of the owner is responsible for the dexterous touches which beautify the garden and pergolas. Neither photography nor word-picture could do justice to the exquisite harmony of coloring throughout this wonderful place, where bloom is continuous over a long period.

Fashioned in Box-edged parterres after the old-time plan and dear to the heart of Americans is such a place as the sunny Box garden at The Appletrees, so charmingly portrayed in this chapter. There is a sweetness and trimness in its simplicity intermingling with the flowers to make it one of the fairest of garden-plots.

We dwell with delight upon the picturesque view of a section of Mrs. Curtis's garden which might well have been taken from an English garden, so closely does it resemble that type which has been our inspiration more especially during the last ten years. In America the 


\section{BEAUTIFUL GARDENS IN AMERICA}

walled garden is found to be useful near the sea, and not undesirable in the cooler northern interior, but by many experts it is not advised in a warm climate, where it prevents the free circulation of air within its enclosure, from which condition some plants may suffer.

In the near-by hamlet of East Hampton, Mrs. Lorenzo Woodhouse has an ingenious scheme of connecting formal gardens that are as remarkable in conception as they are exquisite in color harmony. In length the plan is considerably greater than the width, and the long vista from end to end presents to the artist's eye a lovely picture of flowers, pool, and arches.

Near by, on Huntting Lane, the wild garden belonging to R. Cummins, Esq., is considered the best piece of work of its kind in the country. It is wonderfully composed with natural pools and streams, tea-houses and rustic bridges suggestive of the Japanese art, yet lovelier than the trim Oriental type of water garden because so delightfully wild and overgrown with massive plants, vines, and shrubs, without, however, being disorderly in appearance. It is an especially rare treat in early July at the season of Japanese Iris.

At the west end of Long Island, near New York, gardens are almost as plentiful as those in the region of the Hamptons. For lack of space the illustrations of the lovely garden at Manor House, Glen Cove, and the picturesque pool at Cedarhurst must alone represent this section. Later periods of bloom succeed the Tulips at 


\section{BEAUTIFUL GARDENS IN AMERICA}

the Manor House, giving continuous color all summer to this charming place. The view of Mr. Steele's garden at Westbury is a fine example of an ideal hillside planting leading to the flower-beds on a lower level.

Probably the oldest garden in New York State is the one at Sylvester Manor, on Shelter Island, between the shores of Long Island and Connecticut. This charming little flower-plot is reached by a short flight of descending steps. Some of its old Boxwood appears in the illustration of the pool which is a part of the garden scheme. The original owners of Shelter Island were the Manhasset Indians. "In 1651 Nathaniel Sylvester came from England with his young bride, and here they planted the Box, still one of the wonders of the place, and erected the first manorhouse with its oak doors and panels and mantels fitted in England, and brick tiles brought from Holland. The present house was built in 1737 with enough of the woodwork of the old house to maintain symmetry in traditions, and stands to-day as it has stood the better part of two centuries, filled with its old furniture, paintings, and curios. Here is kept the cloth of gold left by Captain Kidd and many other things that time and space forbid mentioning." The old homestead has always remained in the family in direct descent. 


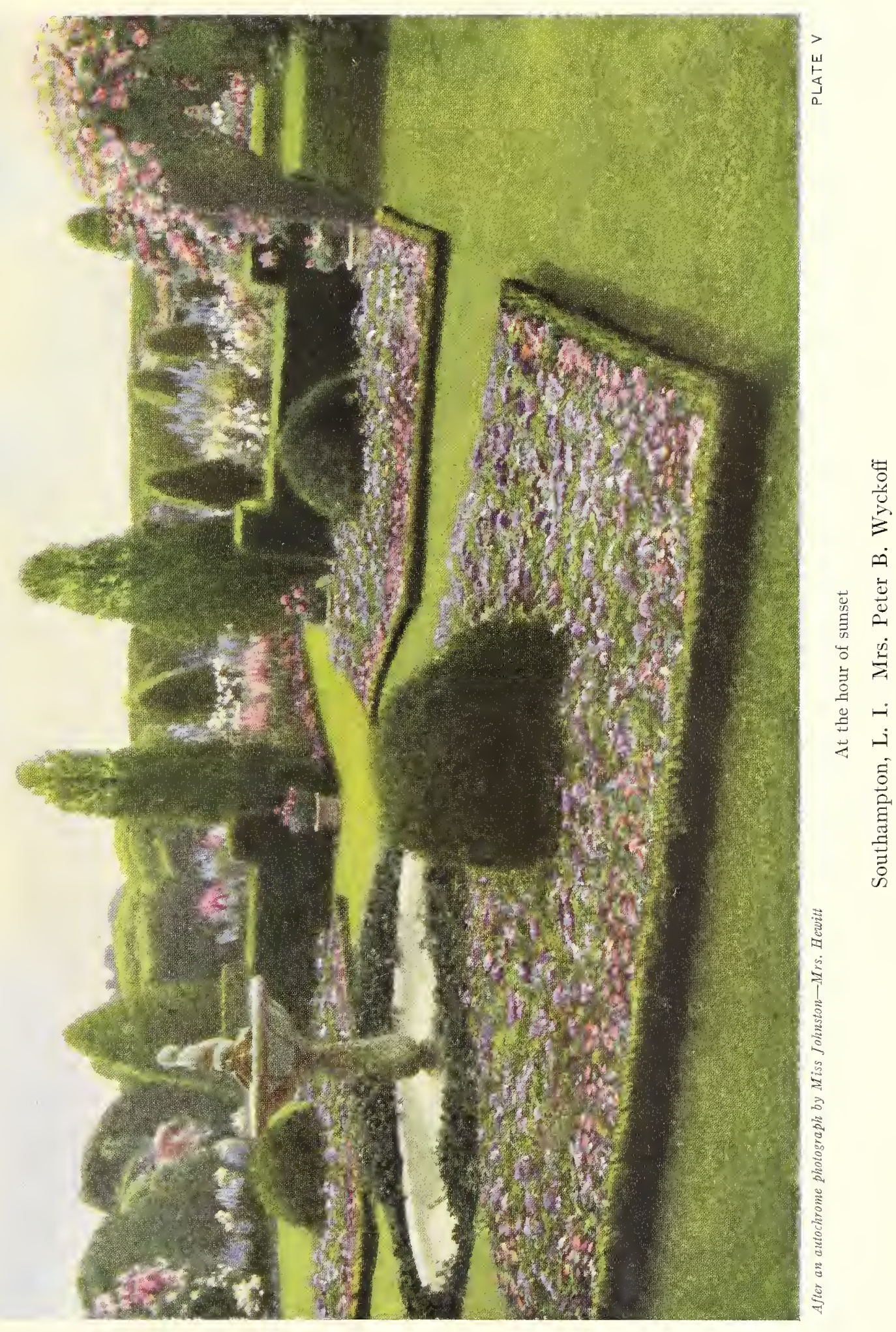





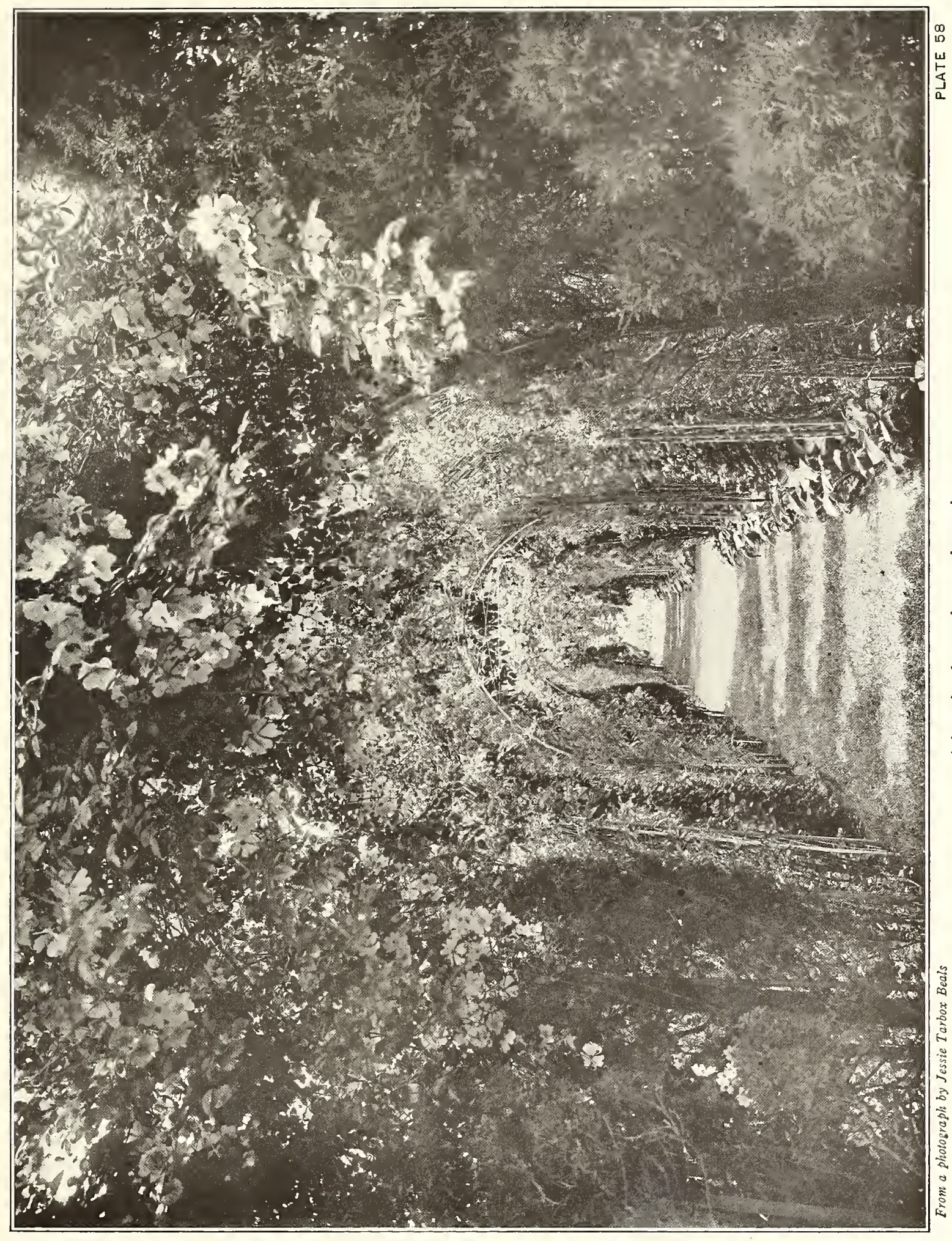

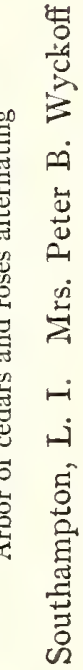





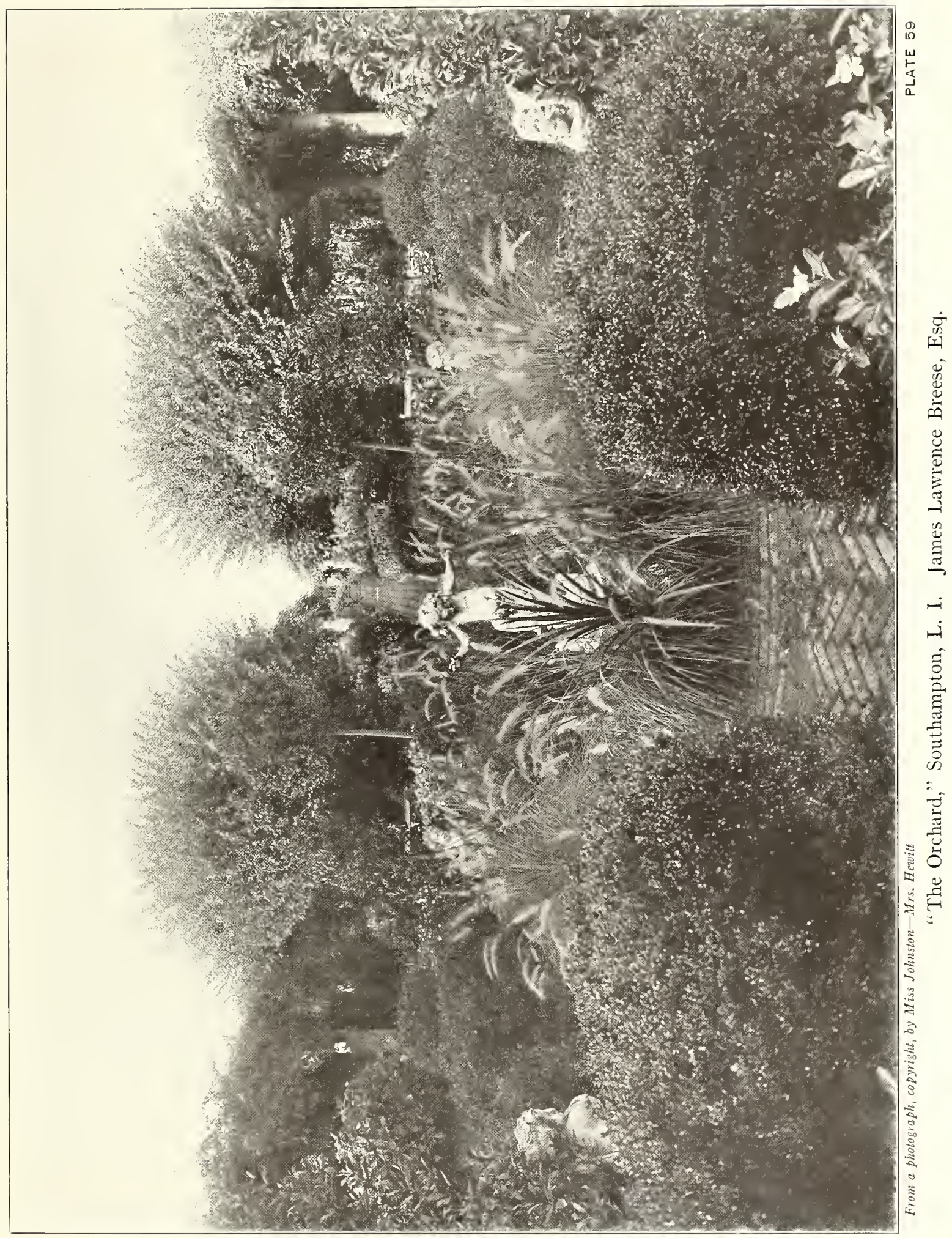





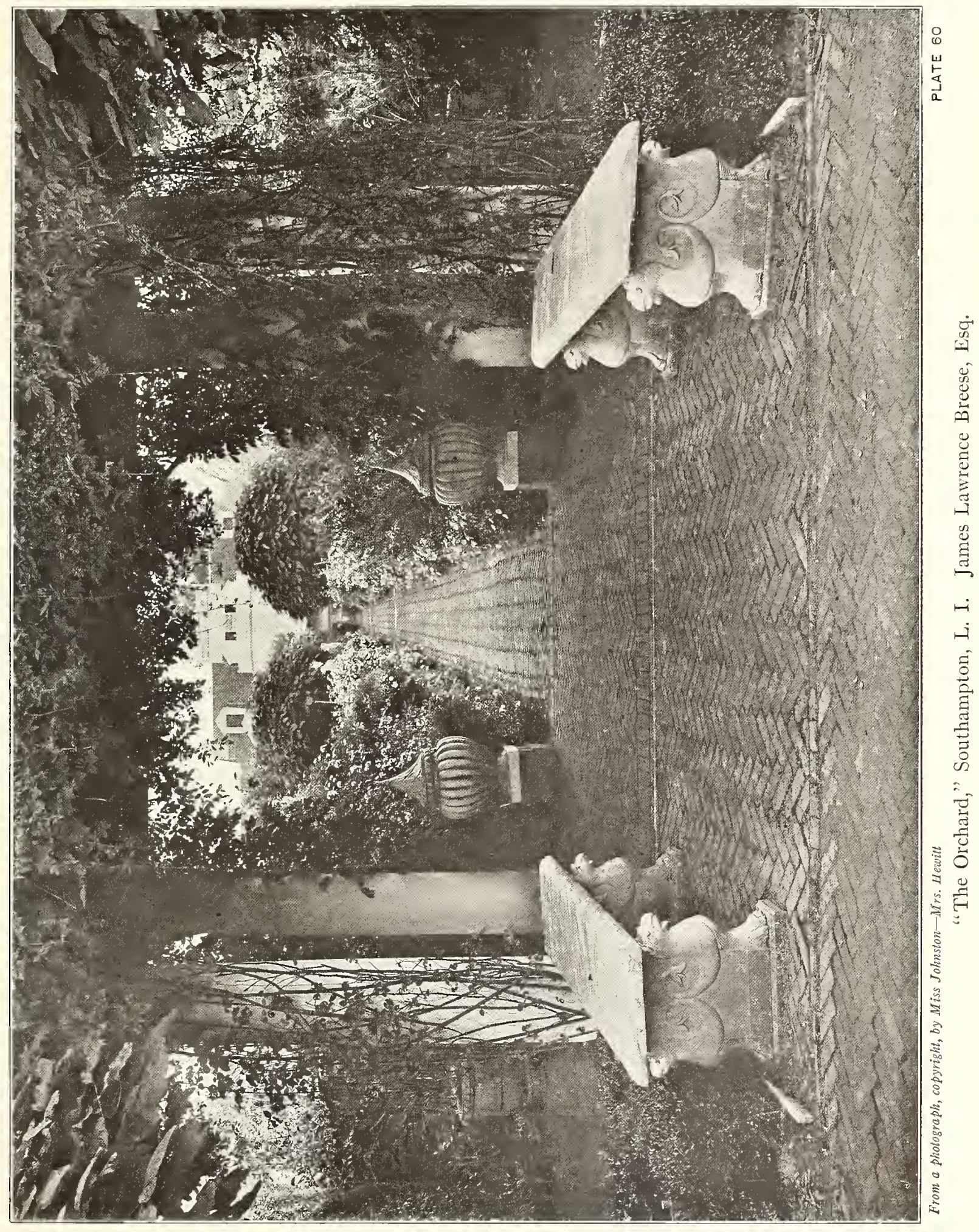





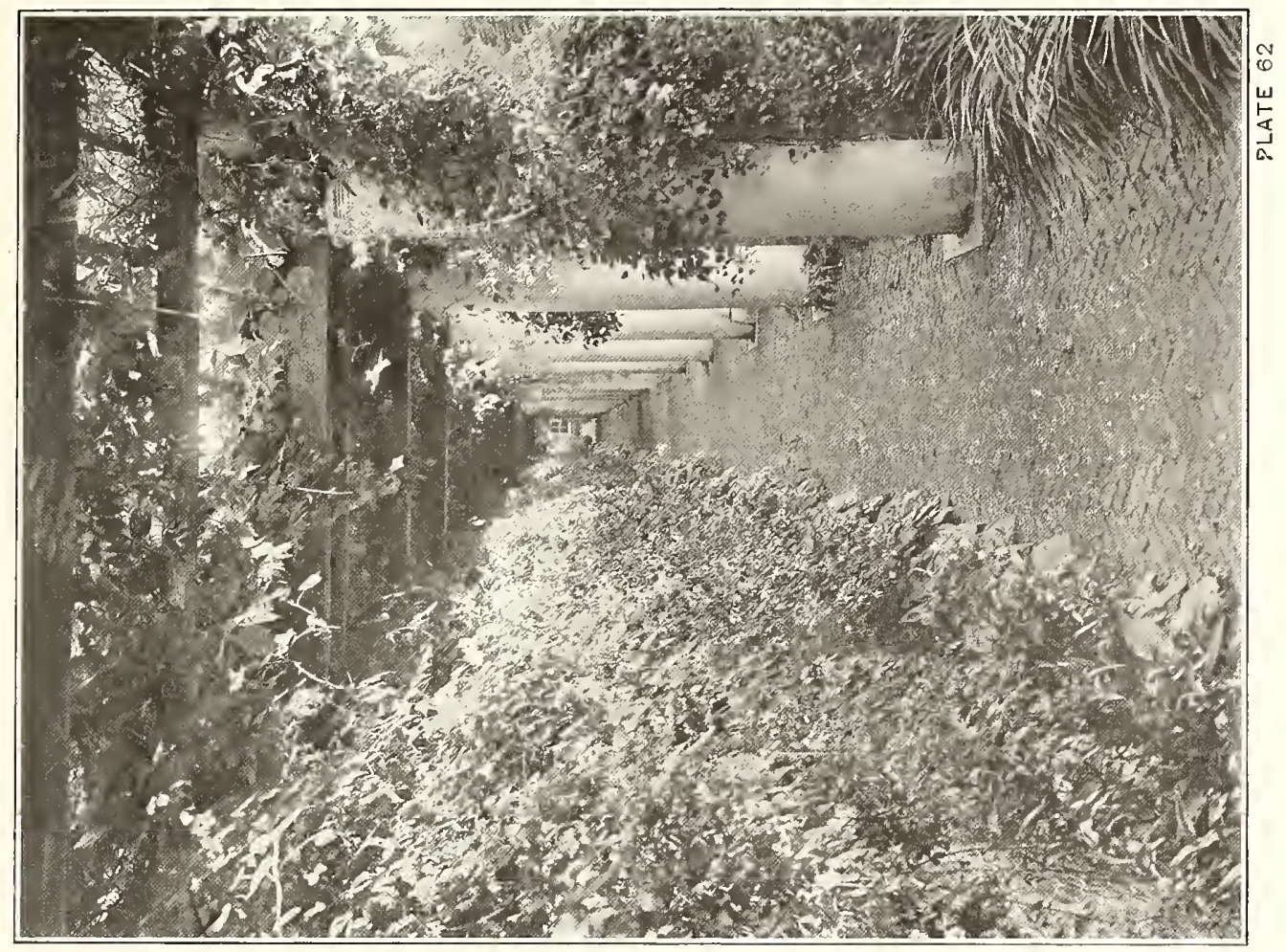



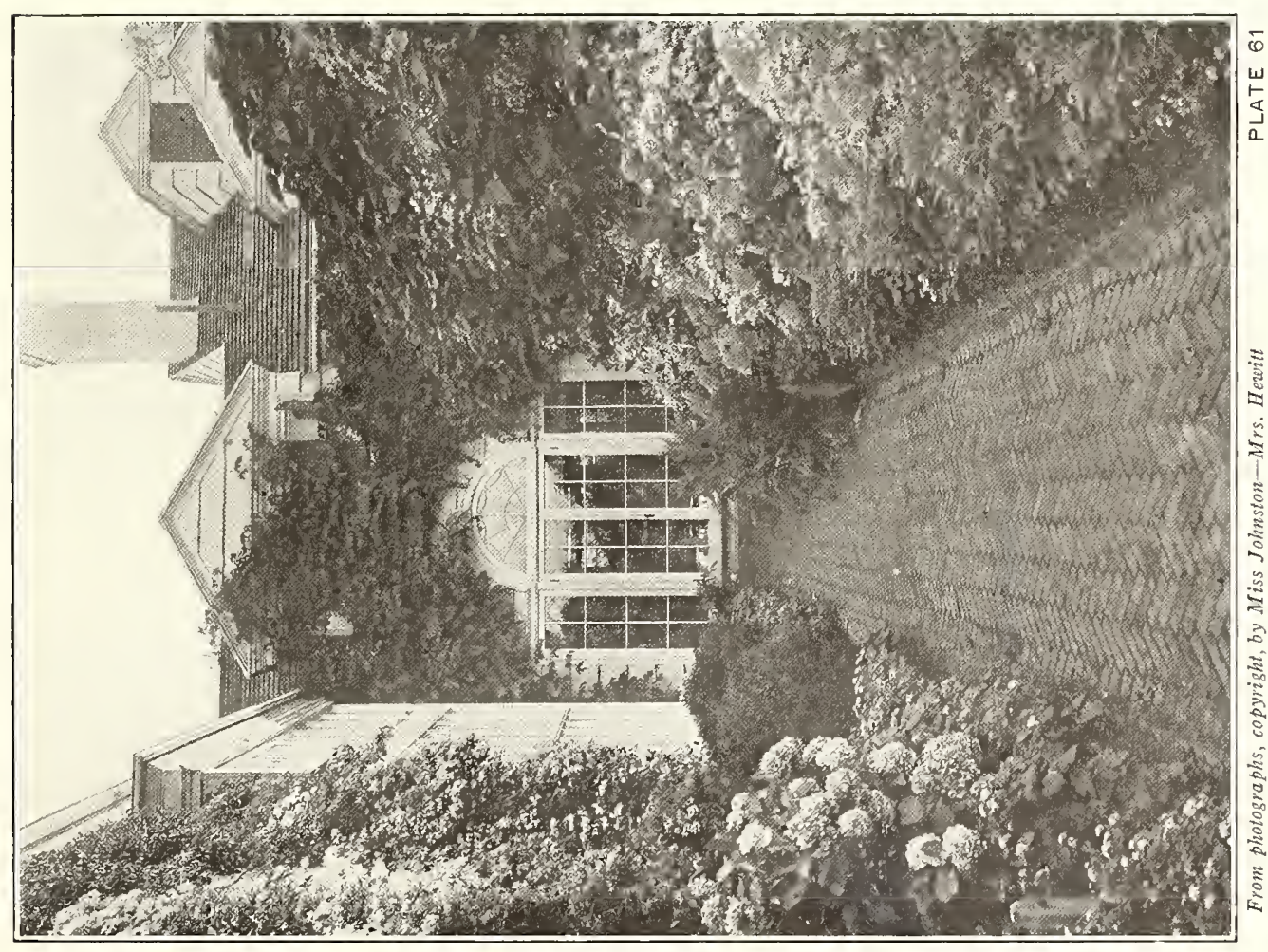





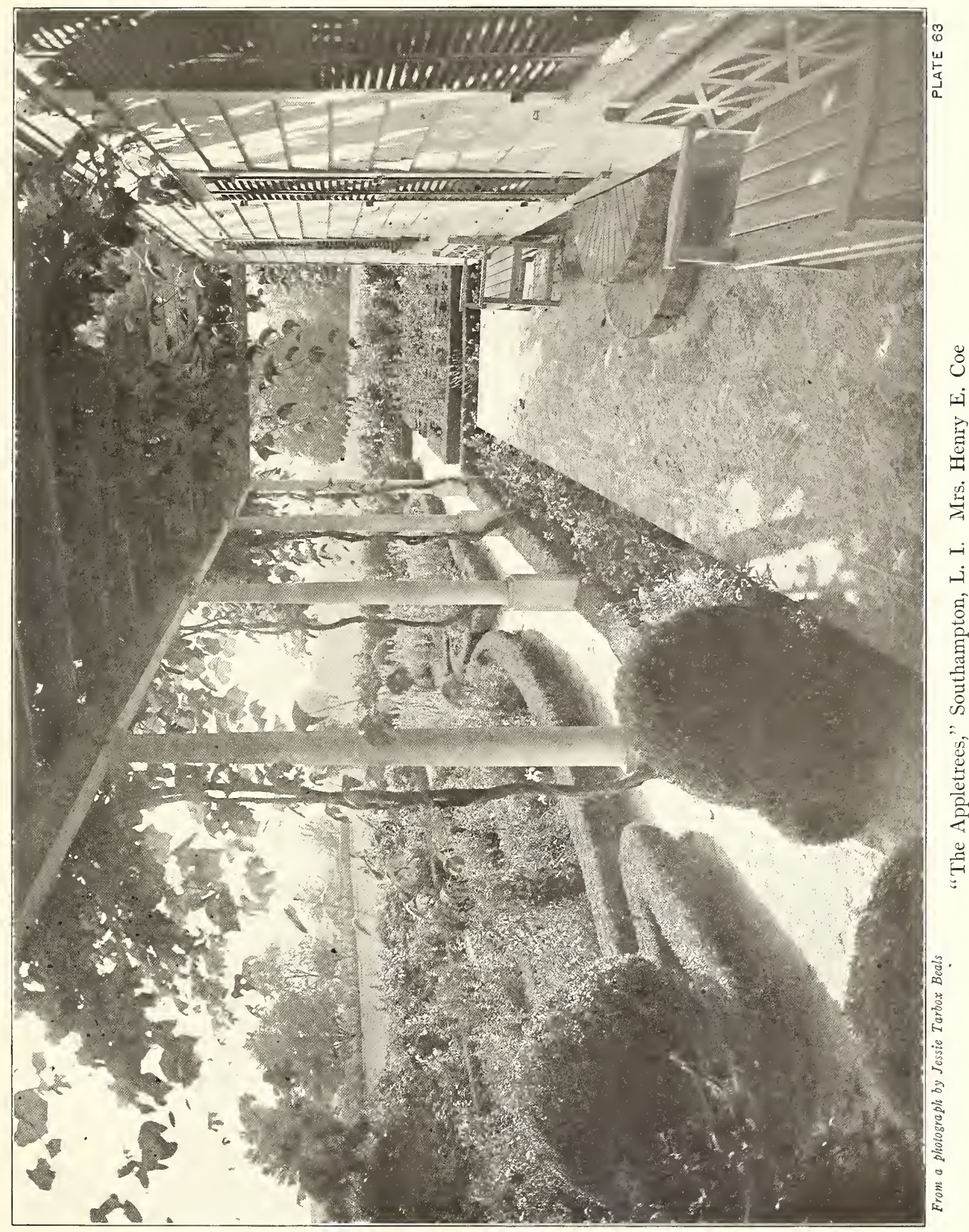




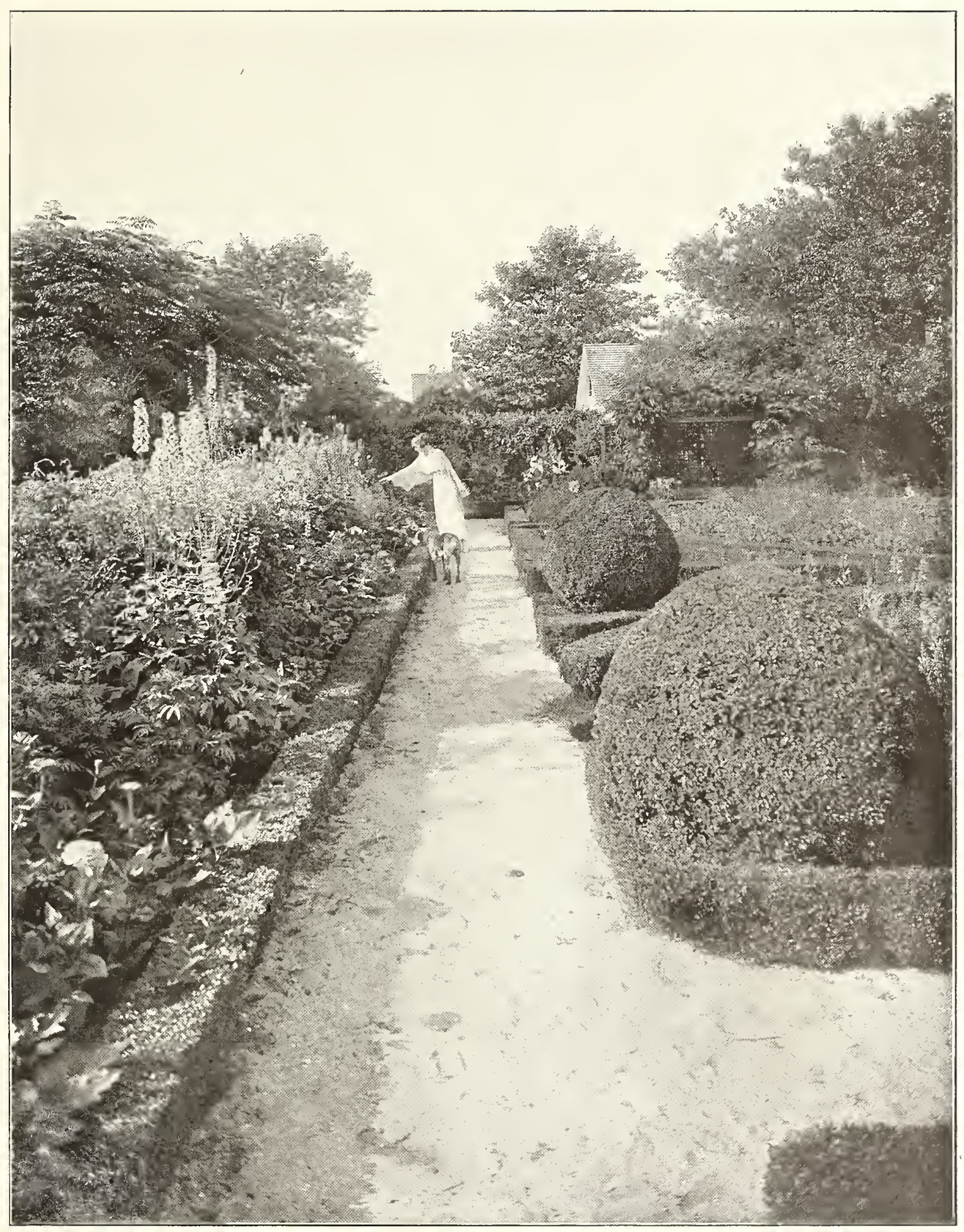

From a photograph by Jessie Tarbox Beals

PLATE 64

"The Appletrees," Southampton, L. I. Mrs. Henry E. Coe 



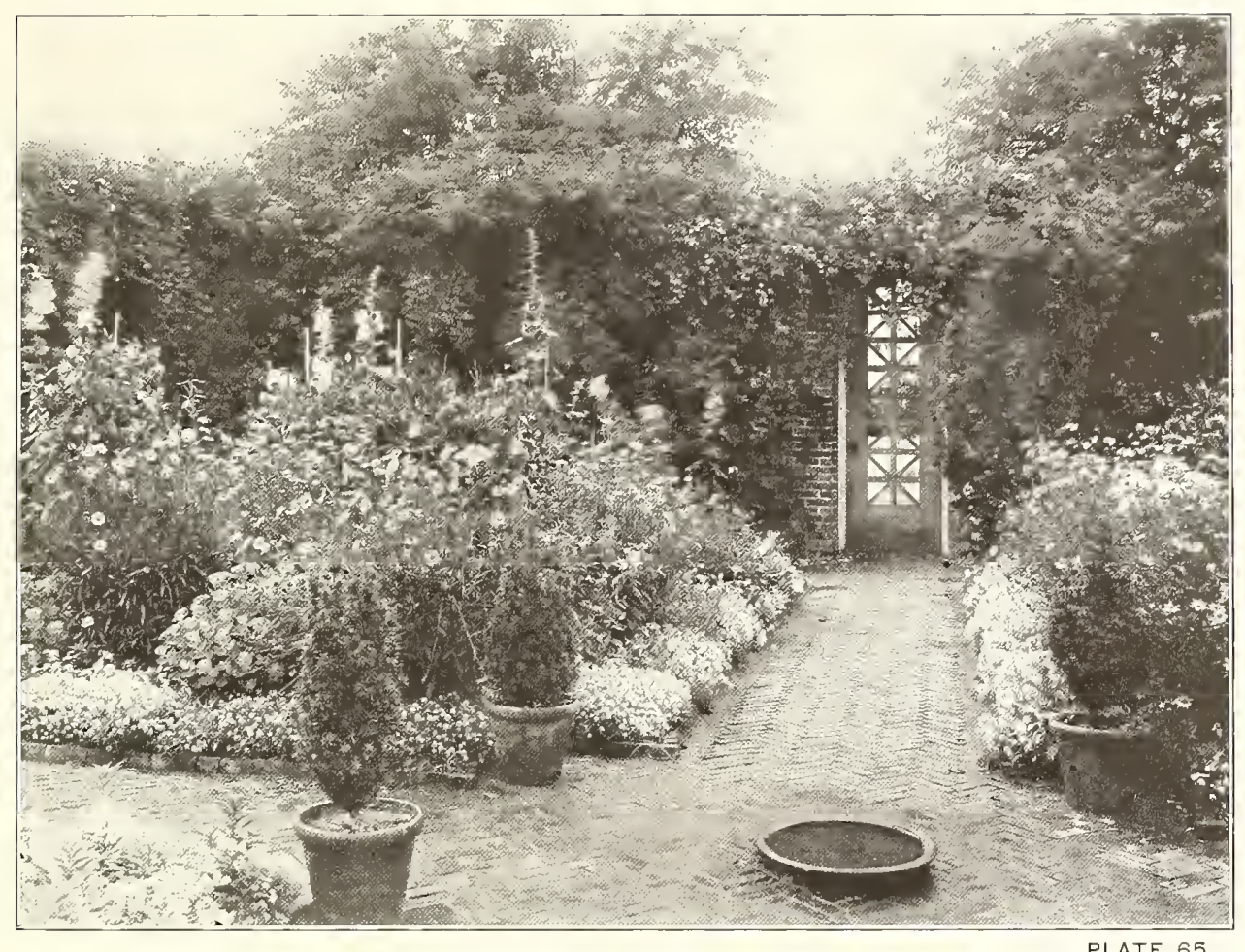

Southampton, L. I. Mrs. G. Warrington Curtis

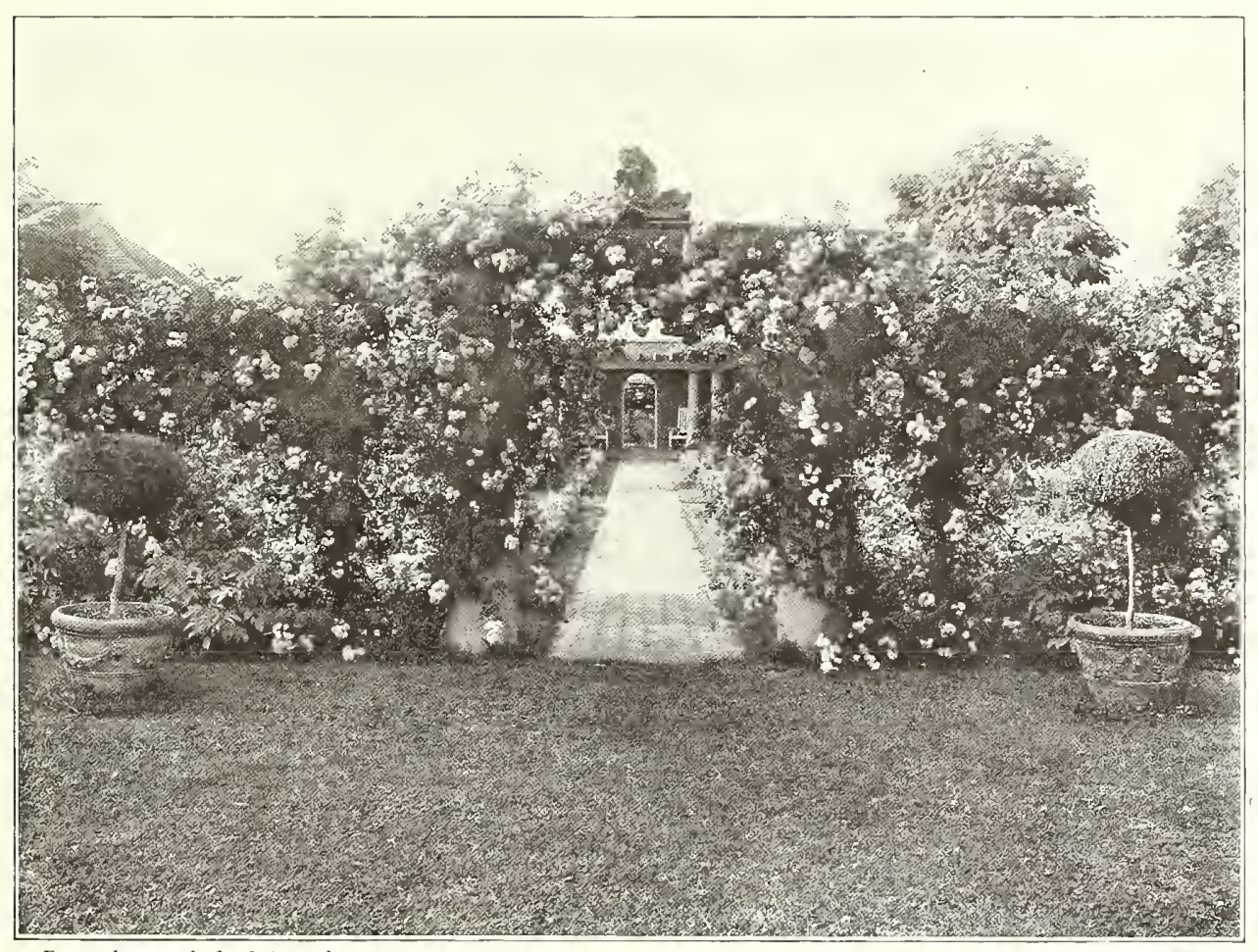

From pholographs by Miss Johnston-Mrs. Hewitt

PLATE 66

East Hampton, L. I. Mrs. Lorenzo E. Woodhouse 



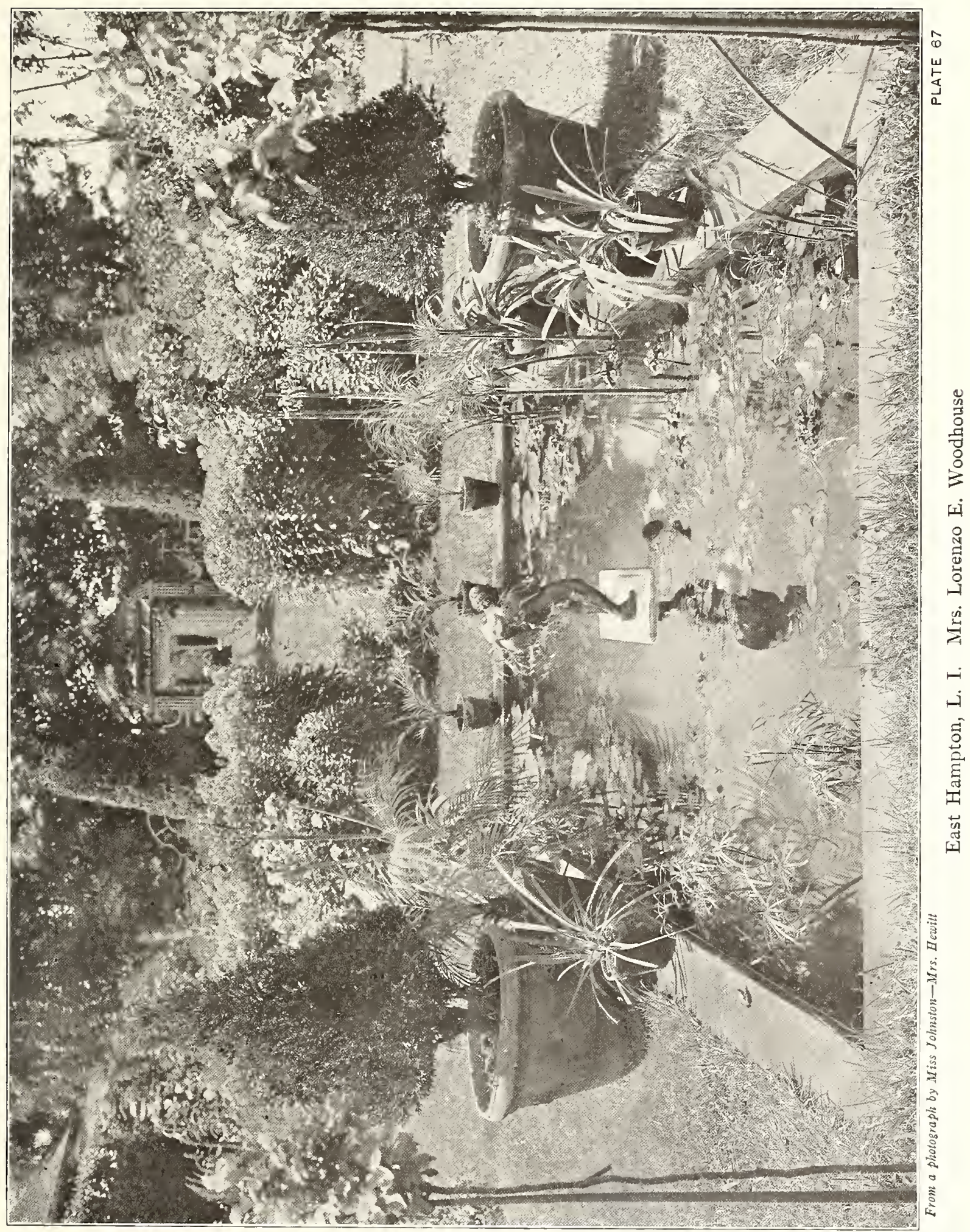


。 


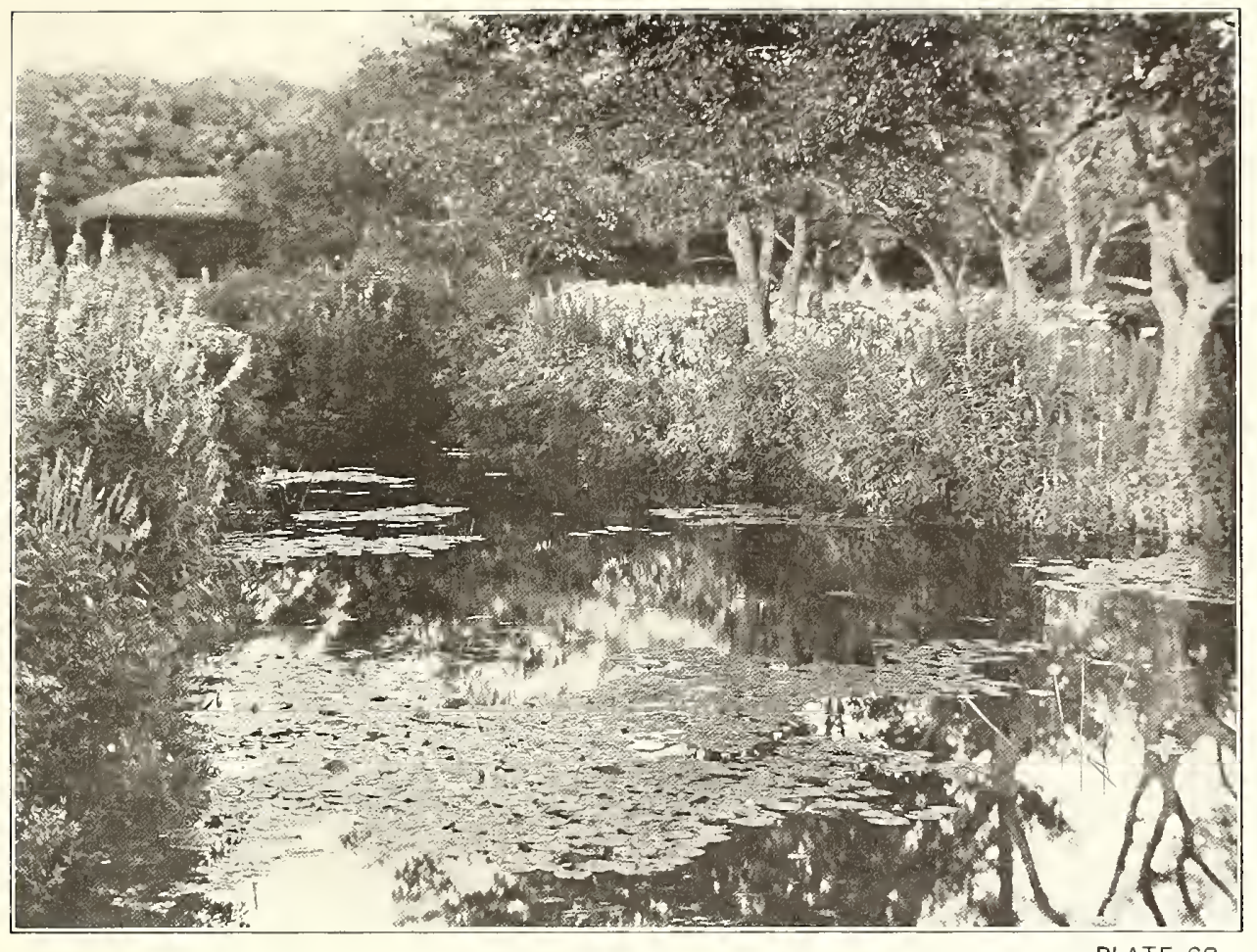

The wild garden

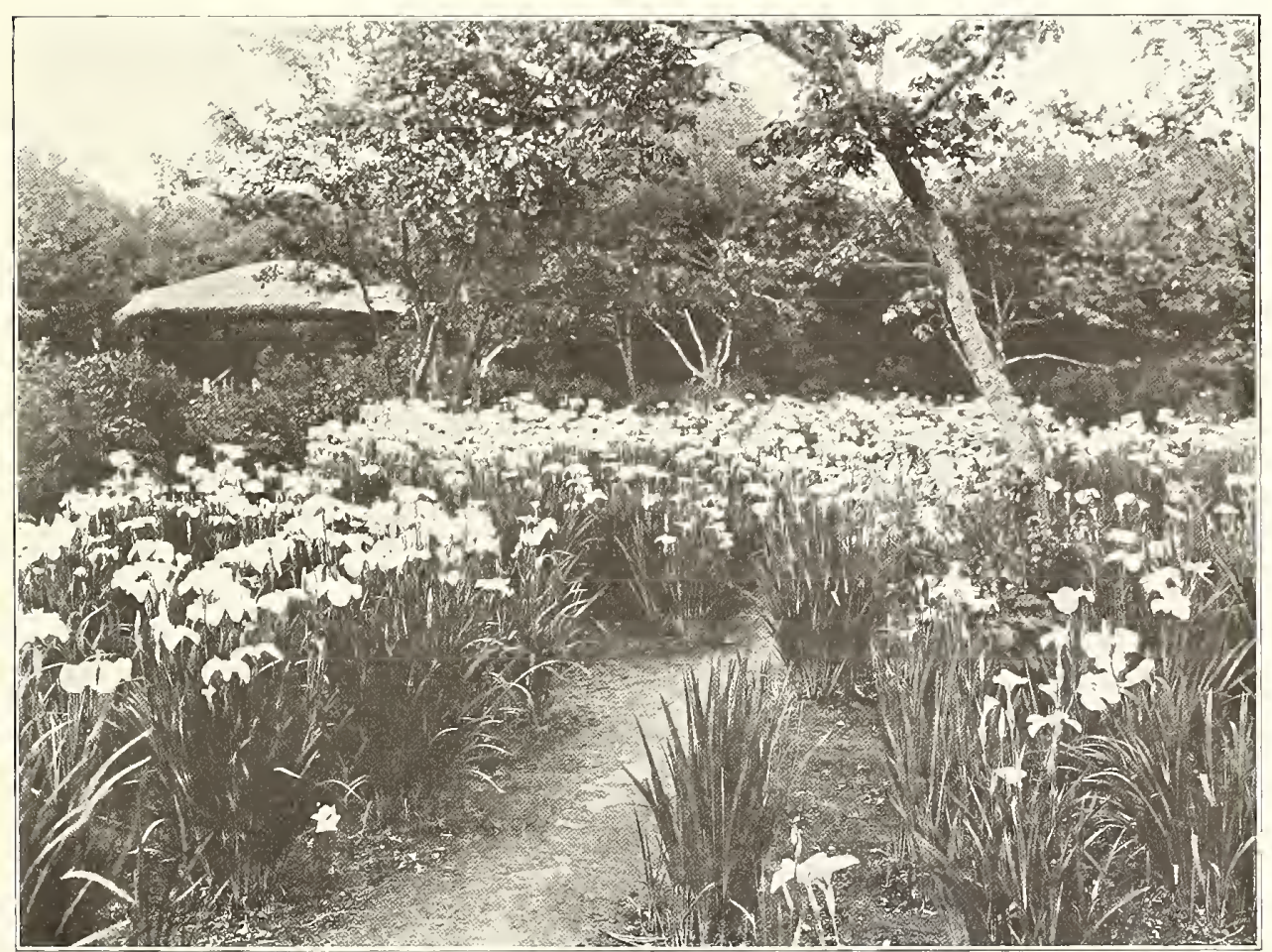

From photographs by Miss Johnston-Mrs. Hewitt

PLATE 69

The wild garden

East Hampton, L. I. Stephen Cummins, Esq. 


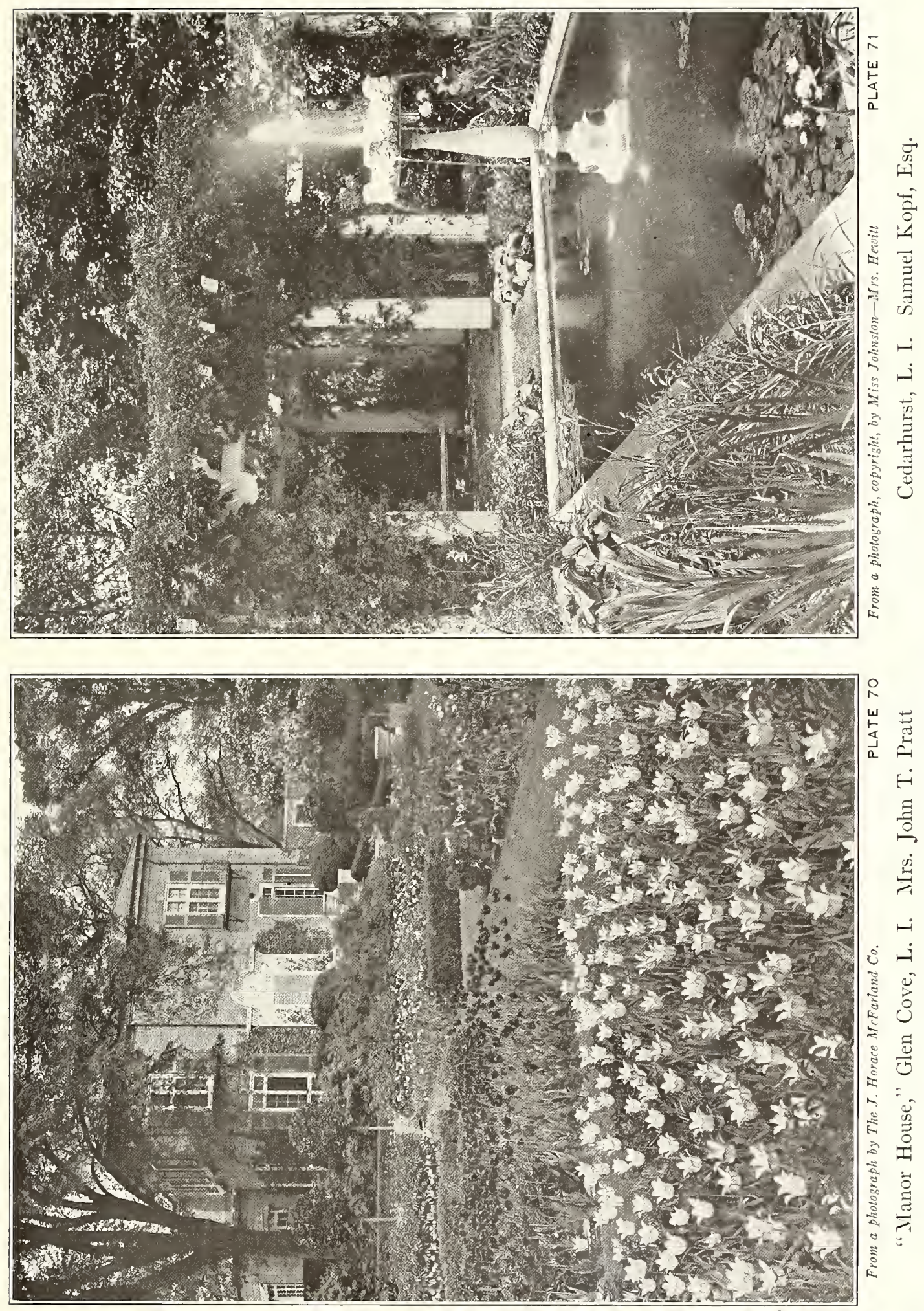



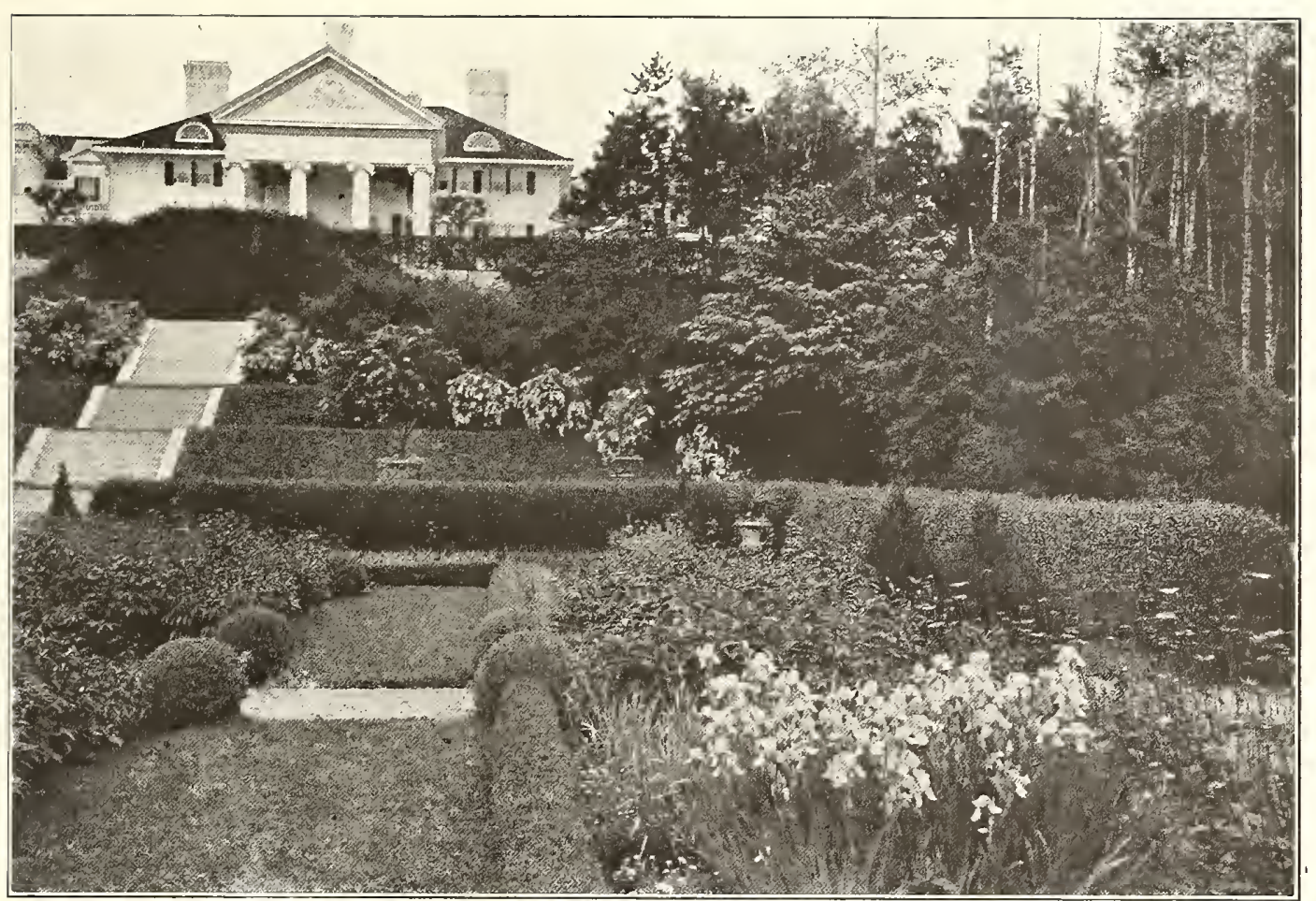

Westbury, L. I. Charles Steele, Esq

PLATE 72

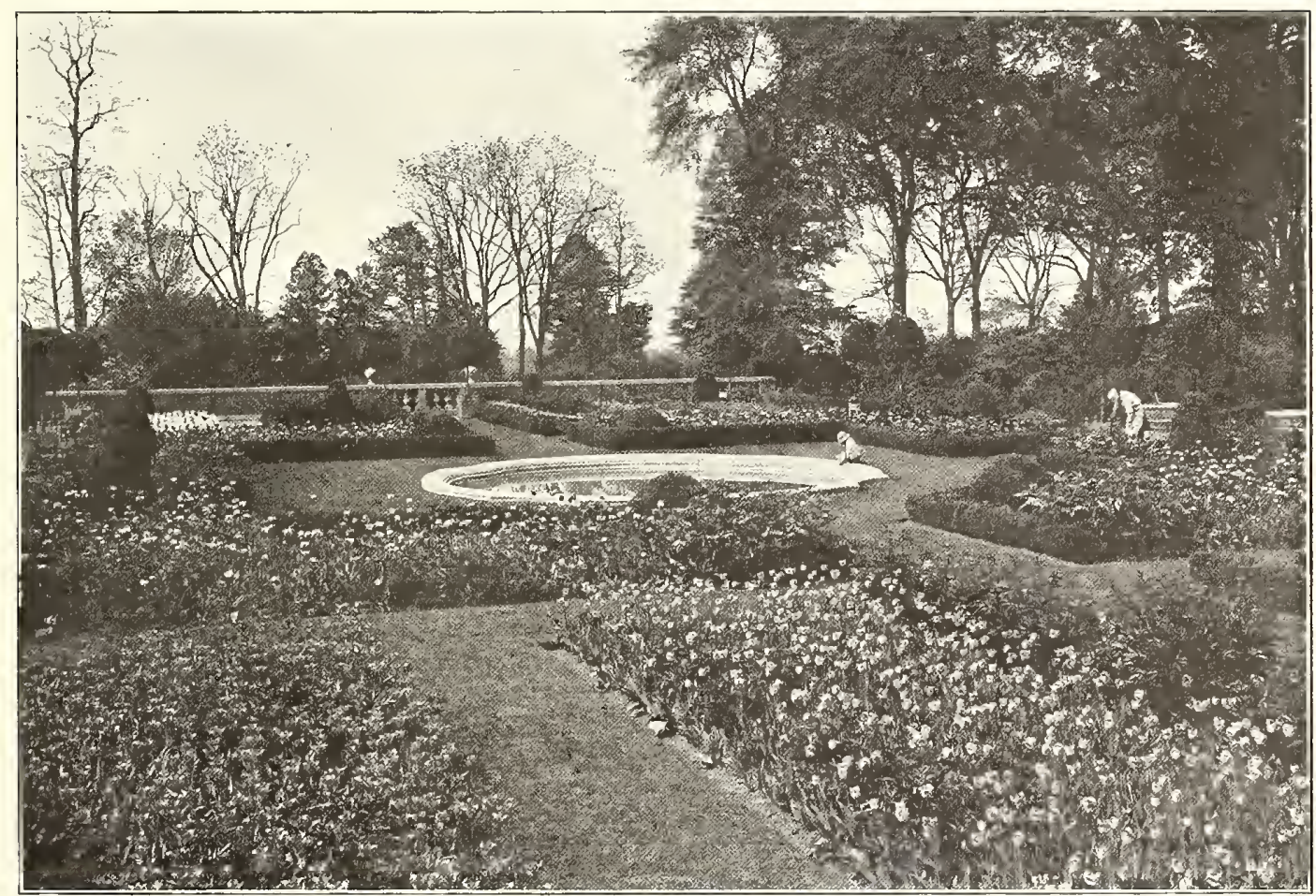

From photographs by The J. Horace McFarland Co.

PLATE 73

"Manor House," Glen Cove, L. I. 



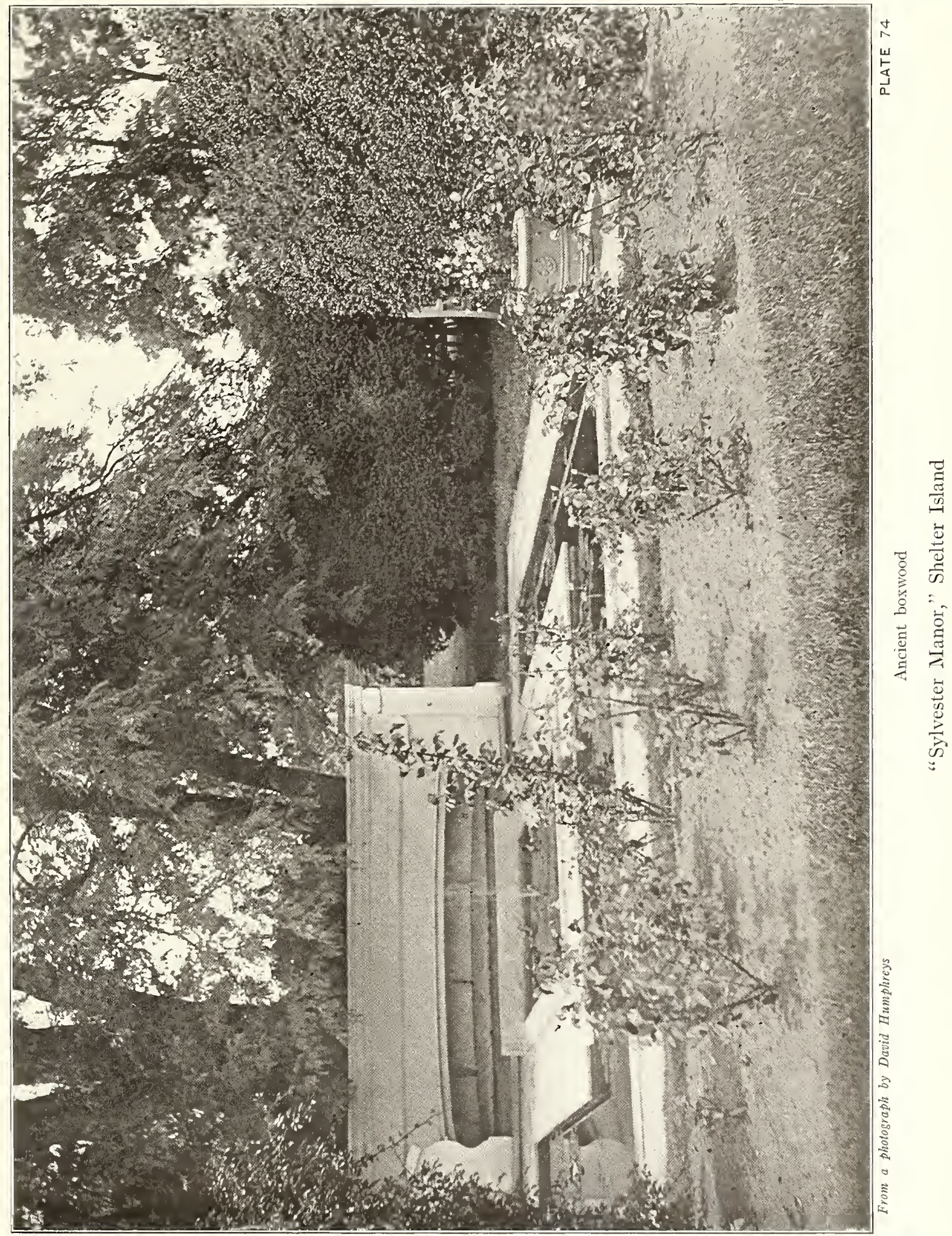





\section{NEW JERSEY}

It would take much time and long travel to discover the State possessing the greatest number of fine gardens, but there is little risk of misstatement in placing New Jersey as fourth or fifth on the list; New York, including Long Island, in the lead, then Massachusetts, and possibly Pennsylvania or California next. Near the sea the climate is, of course, an especial incentive to flower-growing, and along the Jersey coast, especially in Monmouth County, there are numerous gardens. Many excellent specimens are to be seen at Princeton, Trenton, Short Hills, and Morristown, as well as in the country around Bernardsville, in all of which places garden clubs are rapidly developing the cult. Only about fifty miles separate Trenton, Princeton, and Monmouth Beach, in central Jersey, from Morristown, Short Hills, etc., at the north, so that spring gardens practically begin in both sections at the same time, with possibly not more than three or four days' difference between them. While the south Jersey soil does not always encourage gardening, the northern half of the State may be considered on the whole quite fertile, and the summer temperature is not too hot for flowers. Occasional droughts are to be expected, but 


\section{BEAUTIFUL GARDENS IN AMERICA}

the water-supply is usually adequate. In the northern part of the State the usual date for Crocuses is March 25; Daffodils, April 15; Lily-of-the-Valley, May 12; late Tulips, May 10; German Iris, May 22; Oriental Poppy, Columbine, Lupin, and Pyrethrum, May 26; Roses, Peonies, Anchusa, and Sweet William, early June; Delphiniums, June 20; Hollyhocks, July 1. In fact, the climatic condition, as it affects plant life, is very similar throughout the region surrounding New York City — not different enough to require special attention.

The beautiful garden at Glen Alpine is one of prolonged bloom from May 22 until frost, and its planting plans are shown in the author's "Continuous Bloom in America." Both English and Italian inspiration commingle in this beautiful spot. Its setting of old trees on three sides, with the upsloping hill to the rear covered with choice blossom trees and evergreens, as well as the ancient hedge, furnish a background in keeping with the dignity of the place. The pergola is only the beginning of an interesting upper shrub and bulb garden with rambling paths. Other views are given in plates 86 and 172 .

At Cherrycroft, the garden also blooms continuously, and some of its plans are likewise given in the book above-mentioned. The pergola and tea-house lead out to a maze formed by a tall Arbor-Vitæ hedge. Adjoining is a Rose garden, more or less continually in bloom, and near by a garden for cutting-flowers. The outlook over the formal garden, both from house and pergola, is upon 


\section{BEAUTIFUL GARDENS IN AMERICA}

a sea of flowers, possibly unequalled in its profusion of bloom. The four beds encircling the pool are first covered with Pansies and English Daisies, each bed containing one large clump of German Iris, edged with Cottage Tulips. For later bloom, white Petunias fill two beds, light pink Petunias the other two beds. Surrounding the rim of the pool there are Campanula medium, alternating with fallsown Larkspur, the former replaced by Balsam. The four large beds opposite the pool-beds are planted in predominating tones of yellow, blue, pink, and dark red respectively, with white freely intermixed. The beds on the upper level are treated rather similarly.

At both Glen Alpine and Cherrycroft nurseries of coldframes abundantly supply the many annuals and perennials required to fill the broad beds. The prevailing colors required in both gardens are pink, dark red, blues, and yellows. Of the latter, the stronger tones are used only in yellow and blue beds. If there is strict adherence to their planting schemes the richness of their bloom will continue through future seasons. But, alas! how uncertain the fulfilment, when the most necessary flowers may disappoint at the eleventh hour, or the gardeners fail to abide by the plans, especially concerning the color scheme!

At Ridgewood Hill the planting is for spring and autumn bloom, and its three-terraced garden is an excellent piece of work, nestling to the hillside with its vista of hills beyond. This lovely nook deserves to rank among the best in terraced gardens. 


\section{BEAUTIFUL GARDENS IN AMERICA}

Mrs. Fraser's garden, enclosed within the semicircle of the house and a curving Hemlock hedge, is veritably a gem in lovely color-blending. All the periods of the garden season are represented here, difficult as it is to accomplish continuous bloom in narrow beds. First Pansies and early Tulips, followed by the later ones, flood the little court with wonderfully tinted tones. Then Lupins, Canterbury Bells, Sweet William, Chinese Delphinium and Lilium candidum, followed by Larkspur, Zinnia, Snapdragon, Scabiosa, Salpiglossis, Heliotrope, Ageratum, and compact Petunias, Gladioli, and September hardy Chrysanthemum. Constant ministration to the needs of this garden keeps it in a state of fresh bloom and order.

The garden at "Onunda," Madison, attracts many visitors and has long been famous for its beauty and order. It is ablaze with color from May to October. Annuals in richest massing fill all the small beds, and perennials with annuals are closely grouped in the wall beds. The color effect is unusual and the adjoining Rose garden is complete with choicest bloom.

The planting at Blairsden, near Peapack, is probably the most perfect in the State. The accompanying pictures give a limited idea of its beauty. The hill covered with wild shrubs sloping to the lake, the formal garden, the water garden and Rose garden, with the long inclined pathway seeming to lead out to space immeasurable into the green Garden of Everyman, combine with the scenery to make it a place of remarkable beauty. The formal garden 


\section{BEAUTIFUL GARDENS IN AMERICA}

with vine-covered brick wall is like the villa, Italian in design.

The numerous gardens of Short Hills must be represented by one charming glimpse of Brooklawn, an idyllic spot embodying the creative sense of a poet. Its design is quite unusual in the garden world, and perfect in its simplicity. Informal rather than strictly formal, with beds of curving lines and grass paths it may be considered the most original plan in this collection.

Old Princeton, with its picturesque university, is additionally favored in possessing gardens worthy of such associations and equalling the best in our country. The one at Drumthwacket is probably more reminiscent of English gardens than any other. The broad beds, profuse in glowing yet orderly bloom, are especially lovely in June. The garden has the benefit of ancient trees as a setting and the richness of its planting combined with the white balustrade lends a noble effect, comparing favorably with many of those abroad. The beautiful water garden, reached by a winding stone stairway, is encircled by willows and forest trees which fill the little lake with green reflections.

A winter garden is a luxury so rare that one dwells with keenest pleasure upon the view from Thornton - a most perfect specimen of its kind. This evergreen planting is the central scheme of an elaborate plan and divides the perennial and Rose garden on one side from the "cutting" garden on the other. The best of the evergreens in 


\section{BEAUTIFUL GARDENS IN AMERICA}

clipped forms, Barberry with its bright winter berries, Laurel, and Rhododendron foliage unite to enliven the winter scene in this pleasant space, when outside all is gray and lifeless.

Mrs. Seabrook's garden belongs to still another distinctly different class, illustrating a planting which appeals strongly to the many Americans who ardently admire simplicity in outdoor art. Here we find a sweet place in which to live in idle hours, with favorite flowers well-kept, a pool, and shaded retreats from summer sun. 


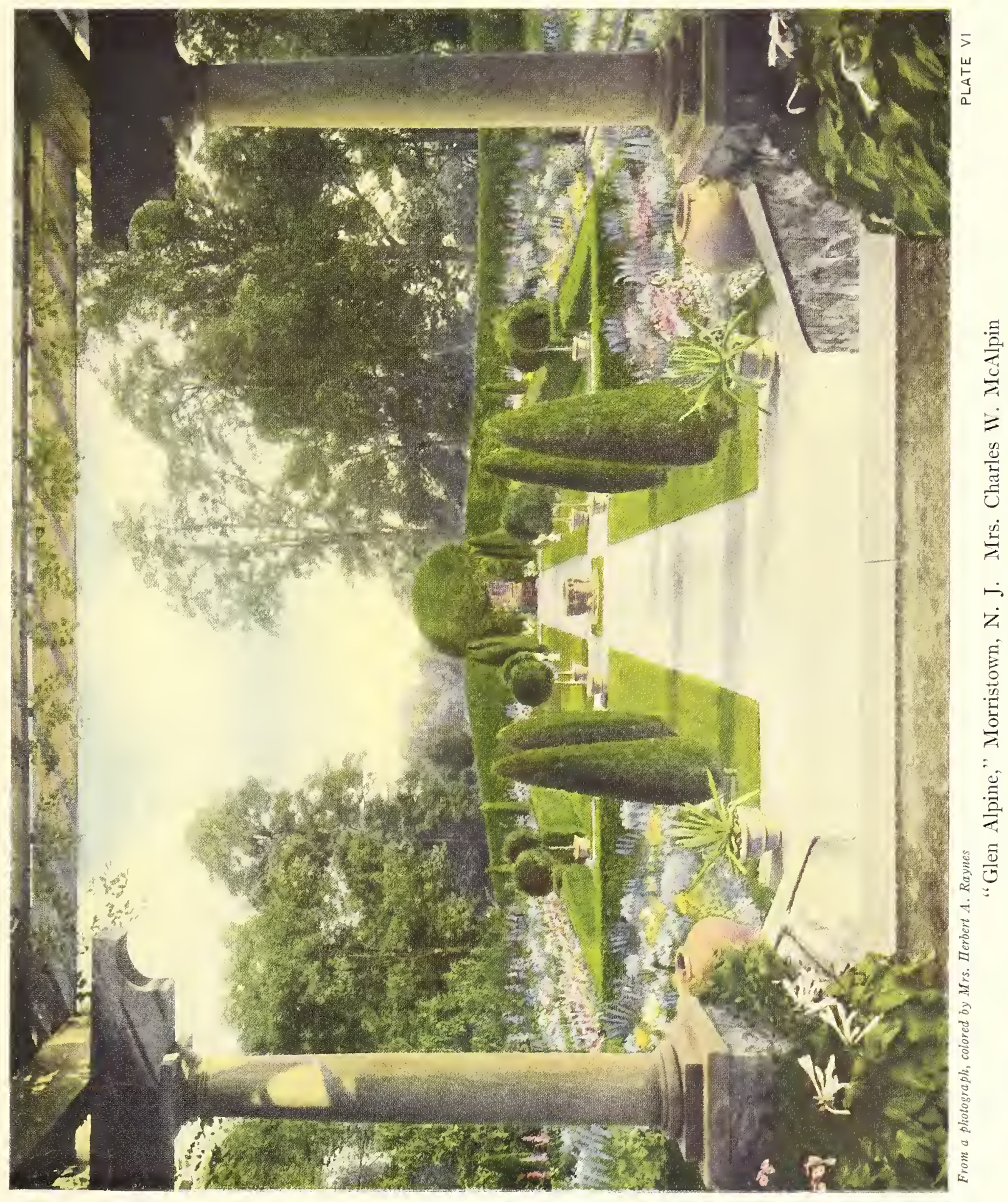




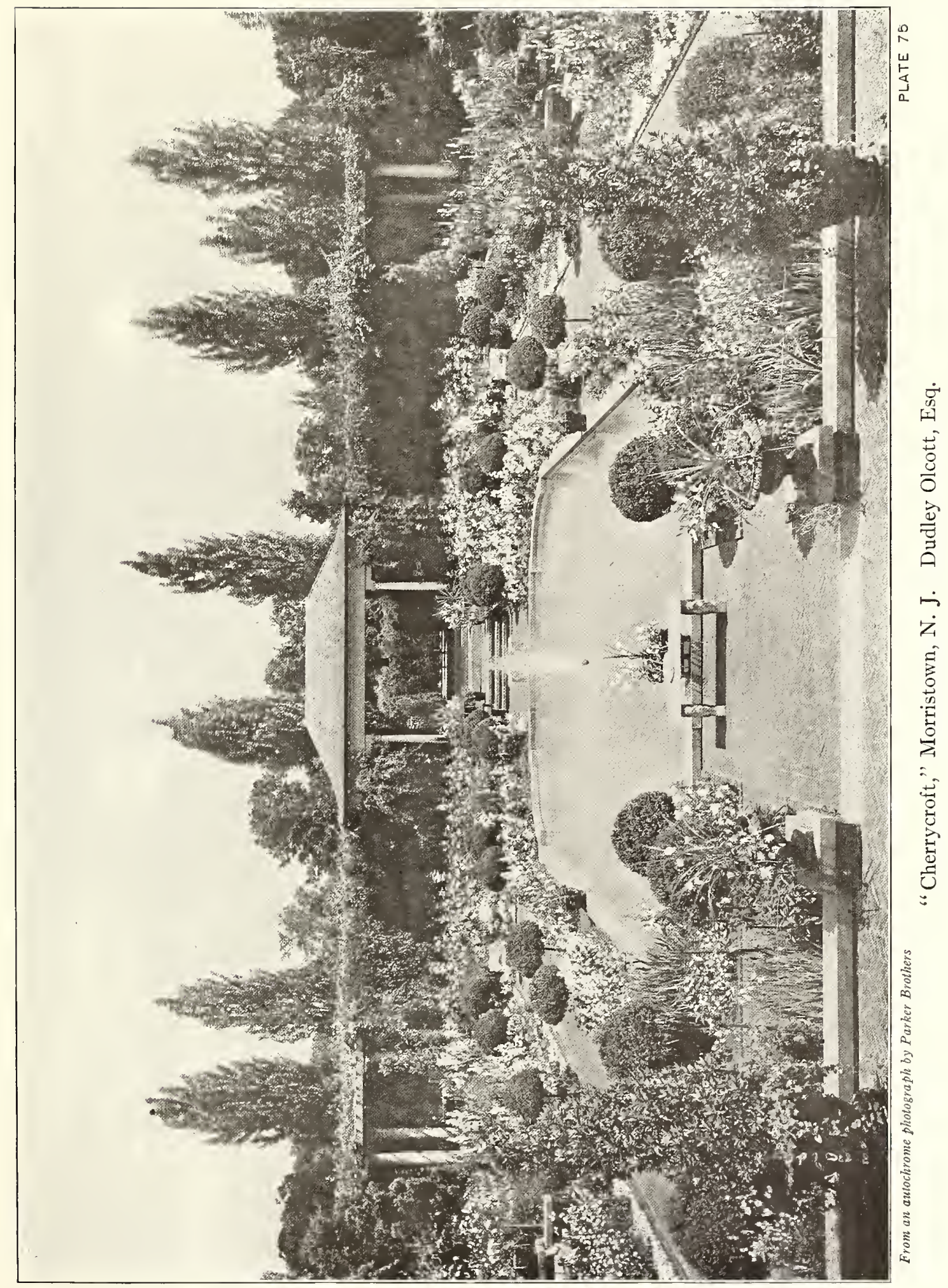




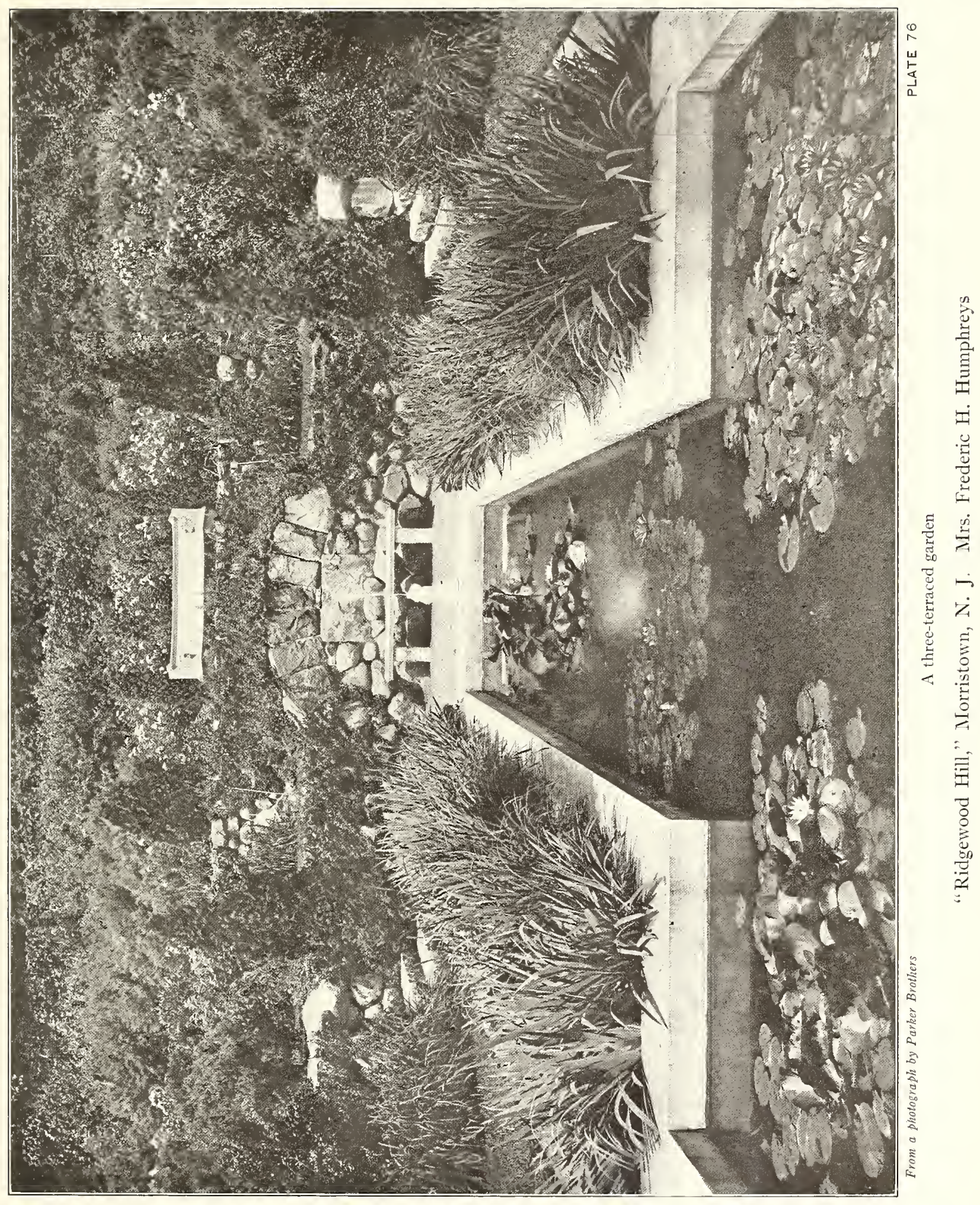





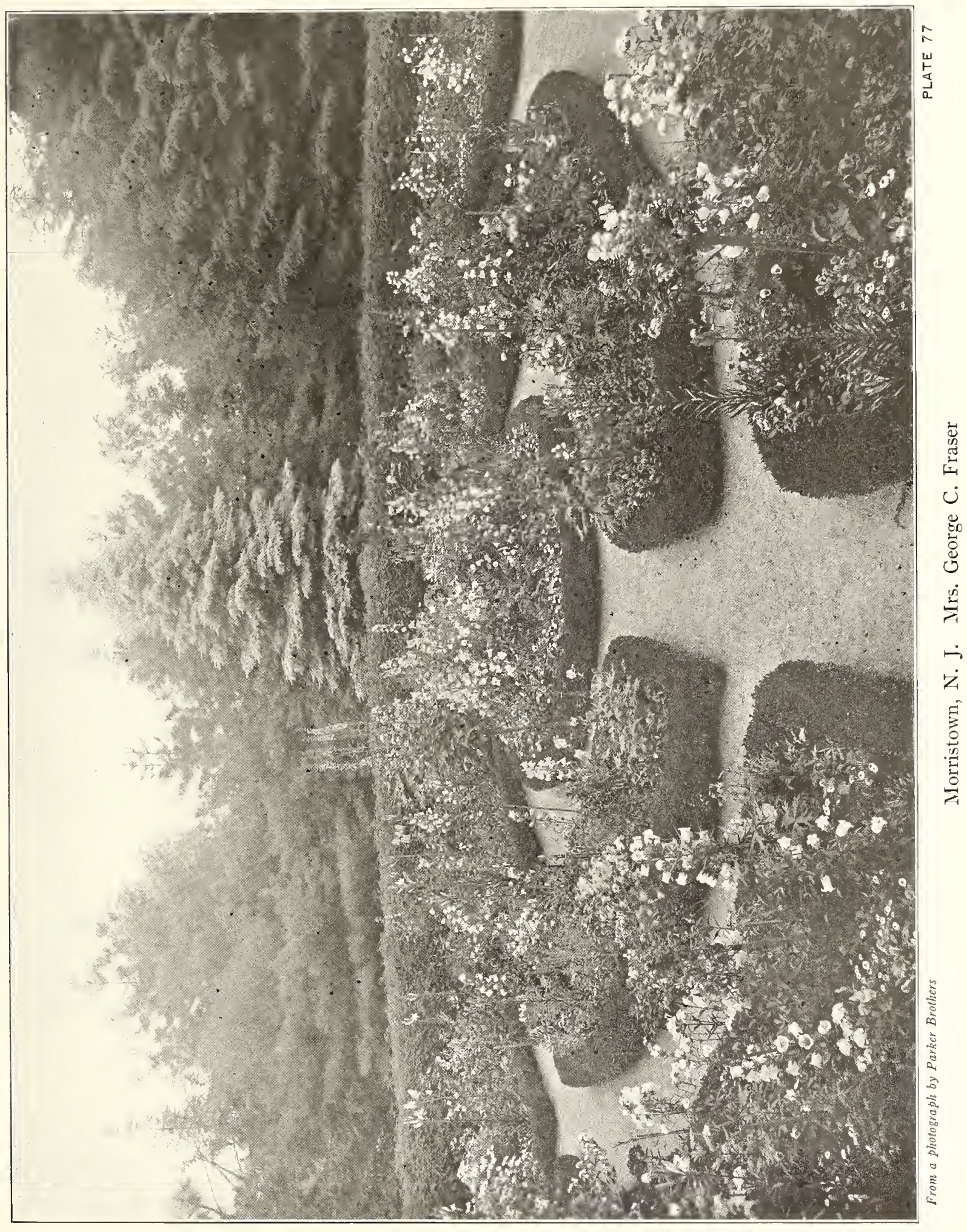


$\cdots$ 


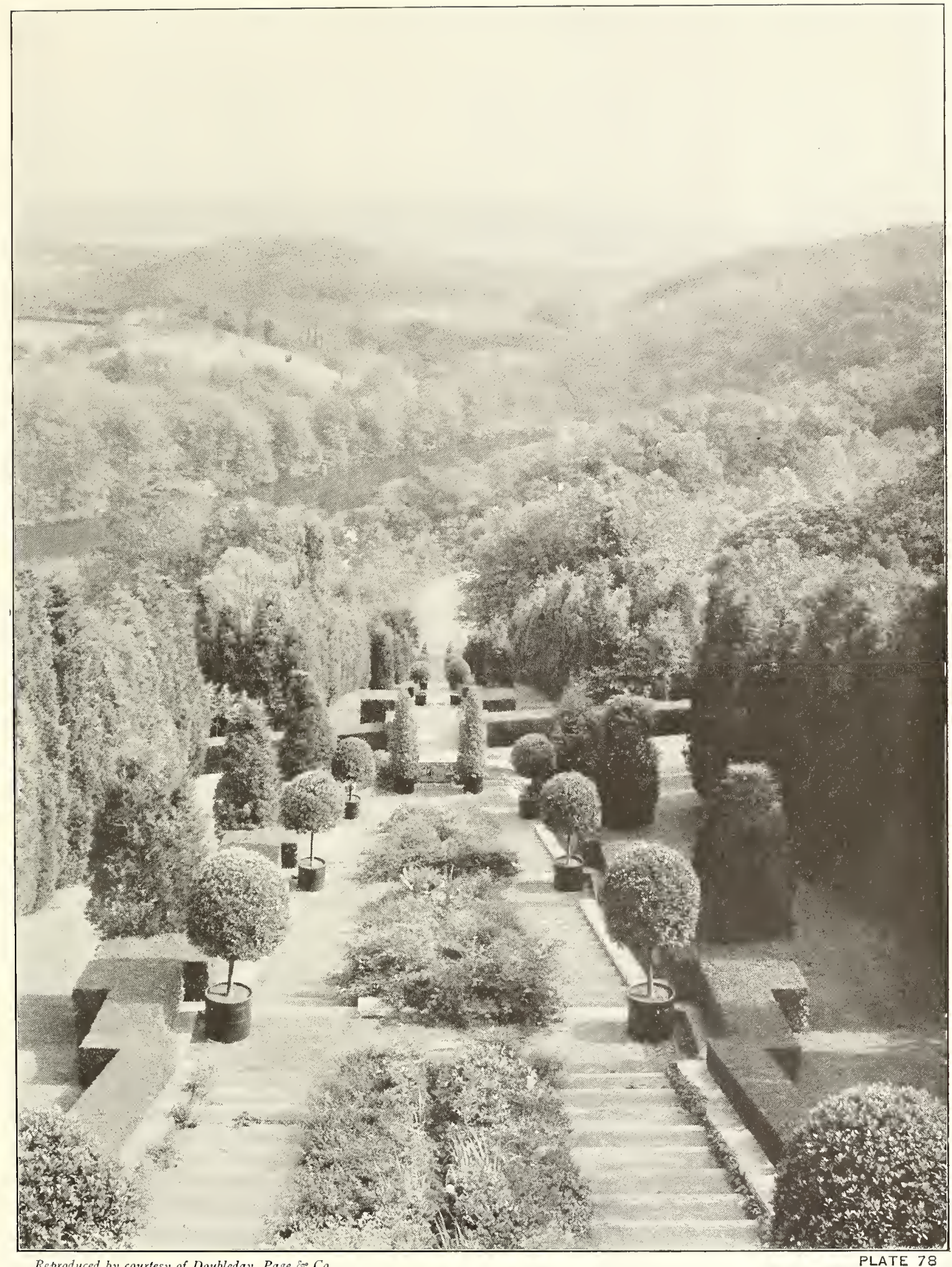

Reproduced by courtesy of Doubleday, Page \& Co.

"Blairsden," Peapack, N. J. C. Ledyard Blair, Esq. 



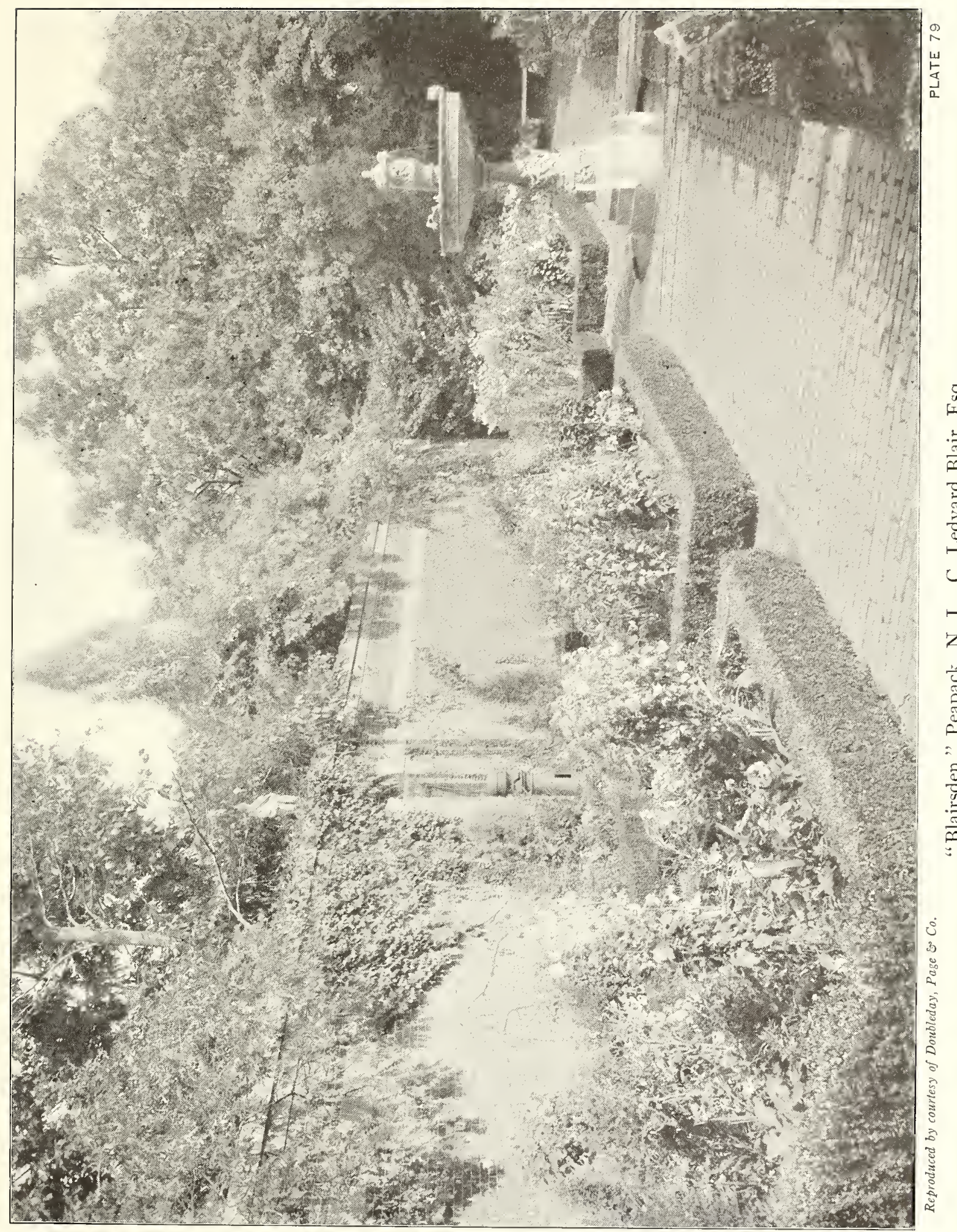





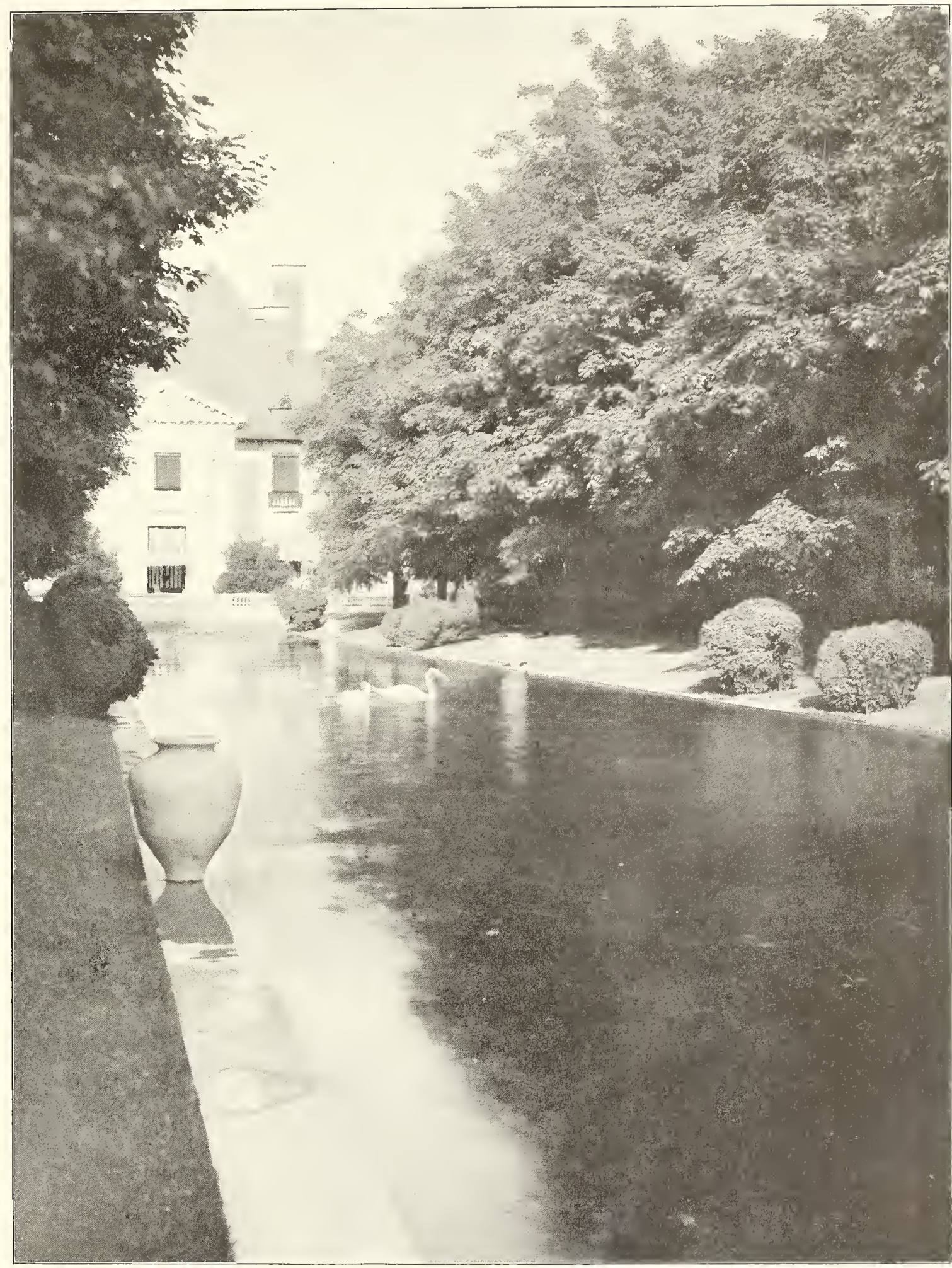

Reproduced by courlesy of Doubleday, Pare \& Co.

PLATE 80

"Blairsden," Peapack, N. J. C. Ledyard Blair, Esq. 



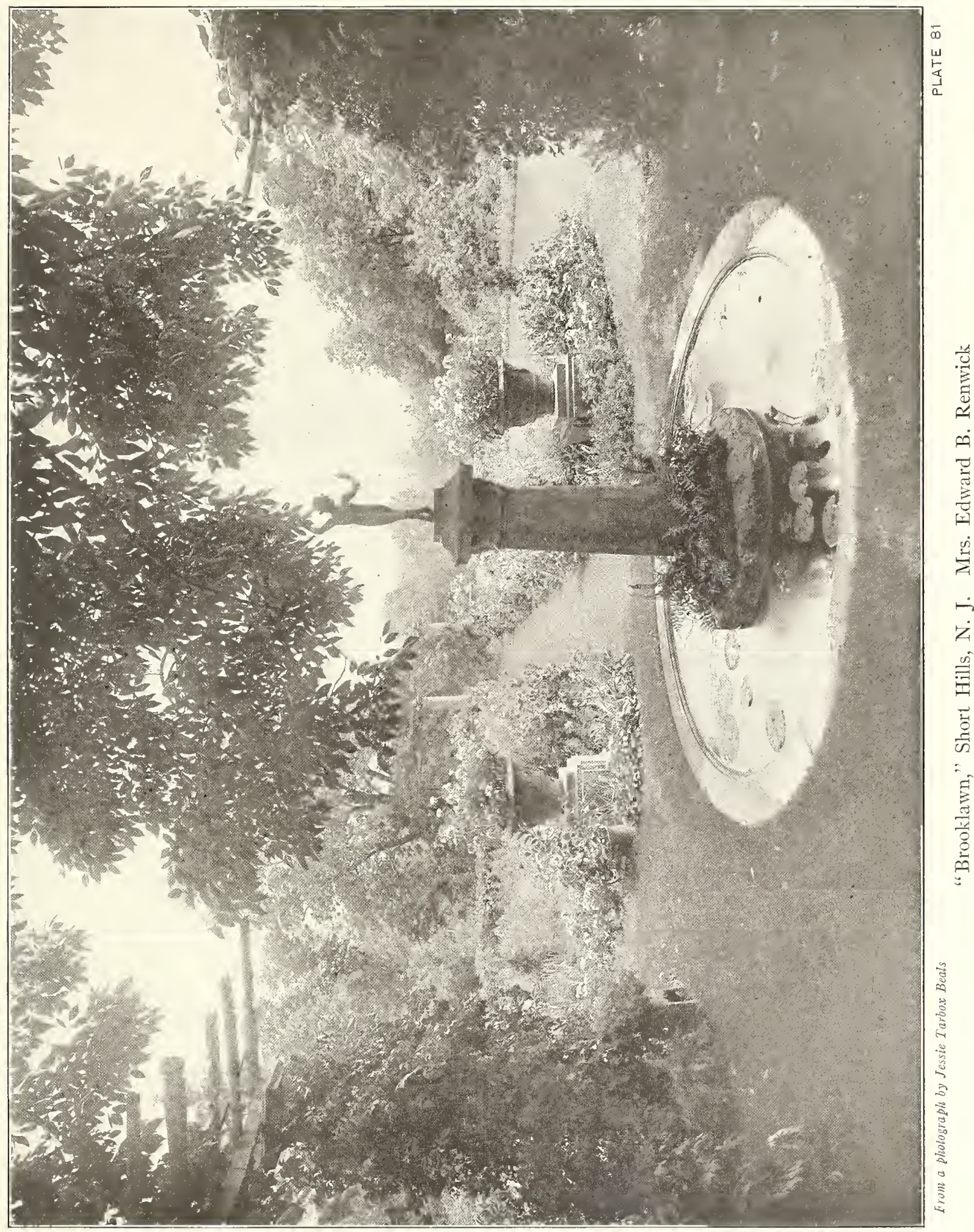





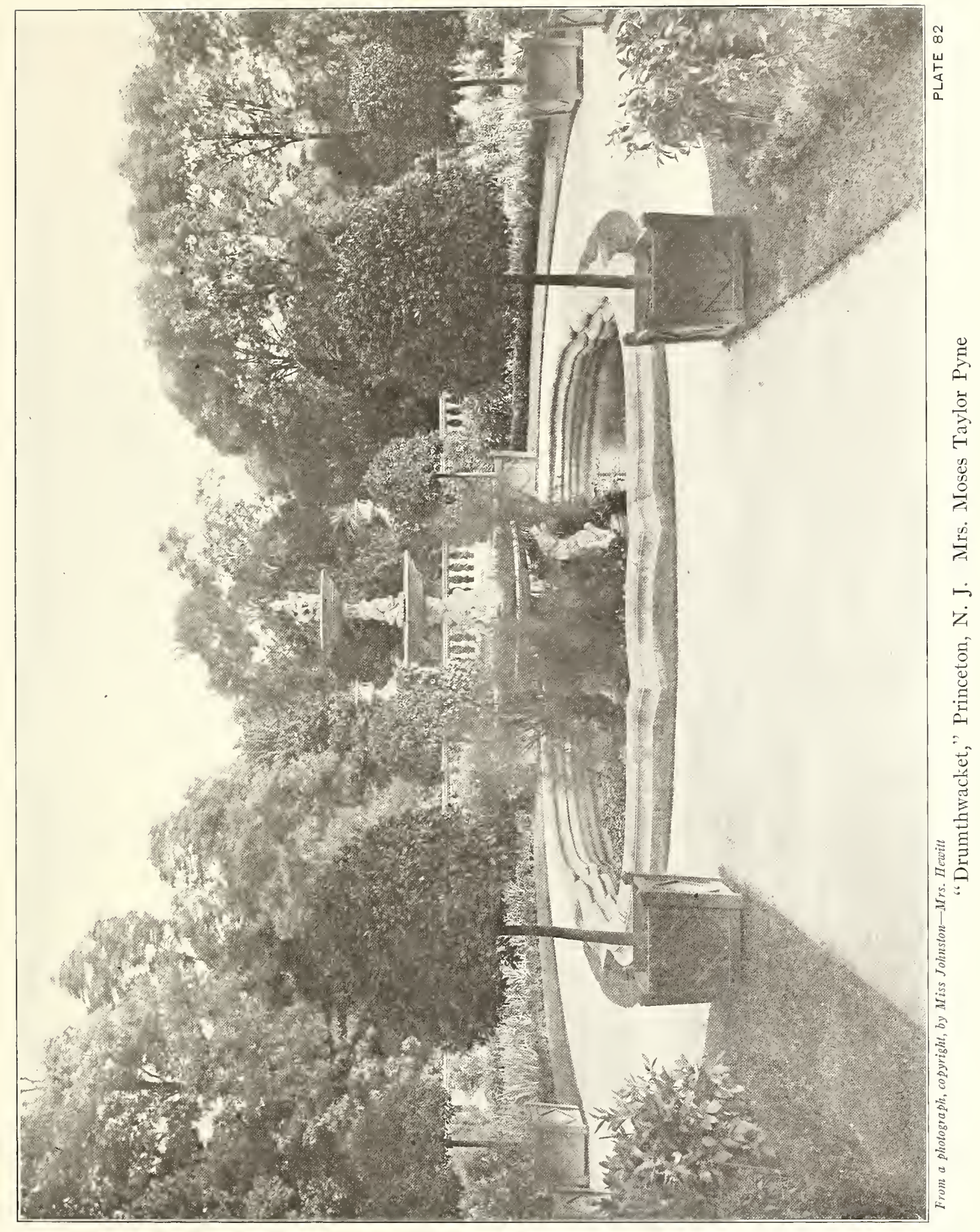





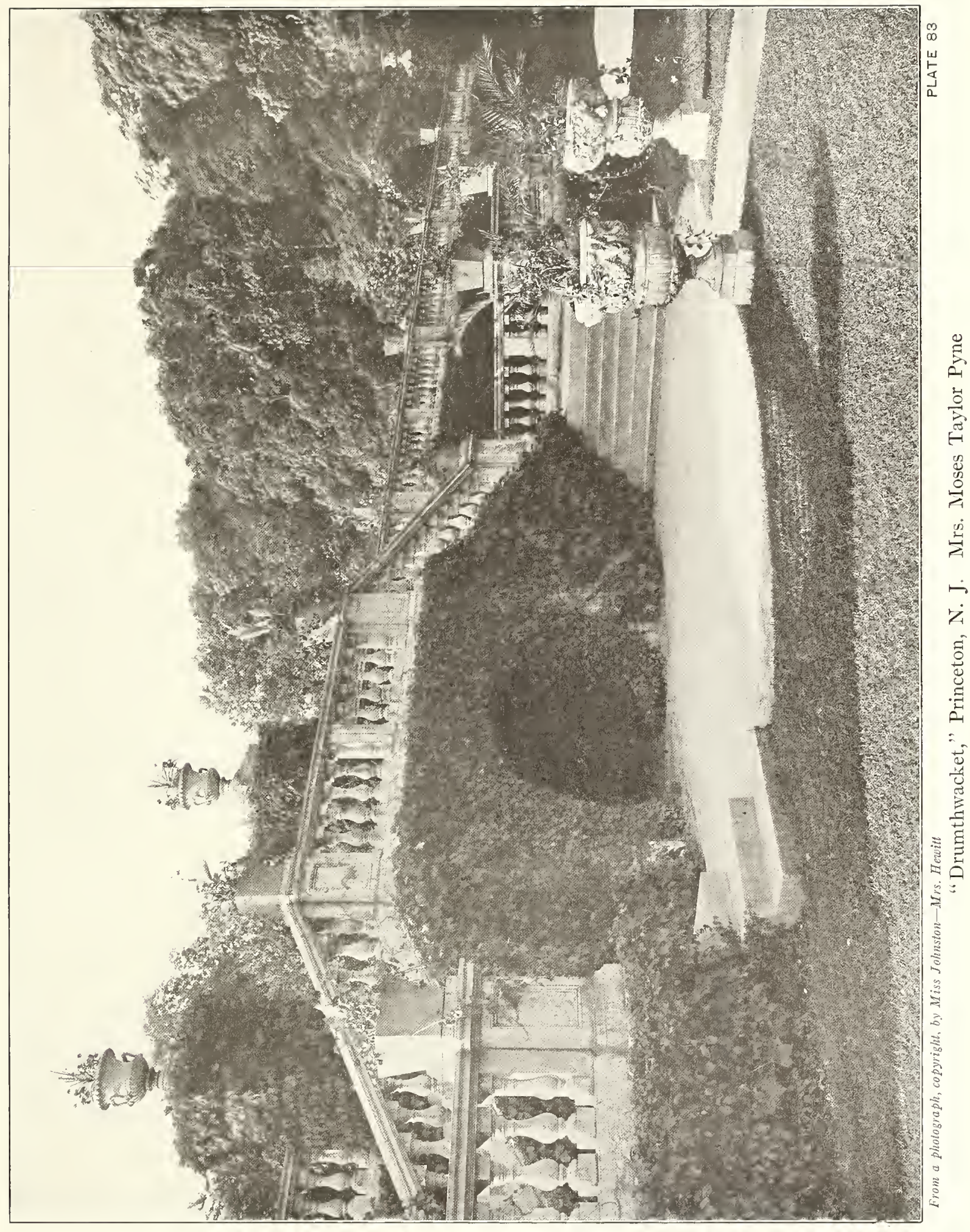





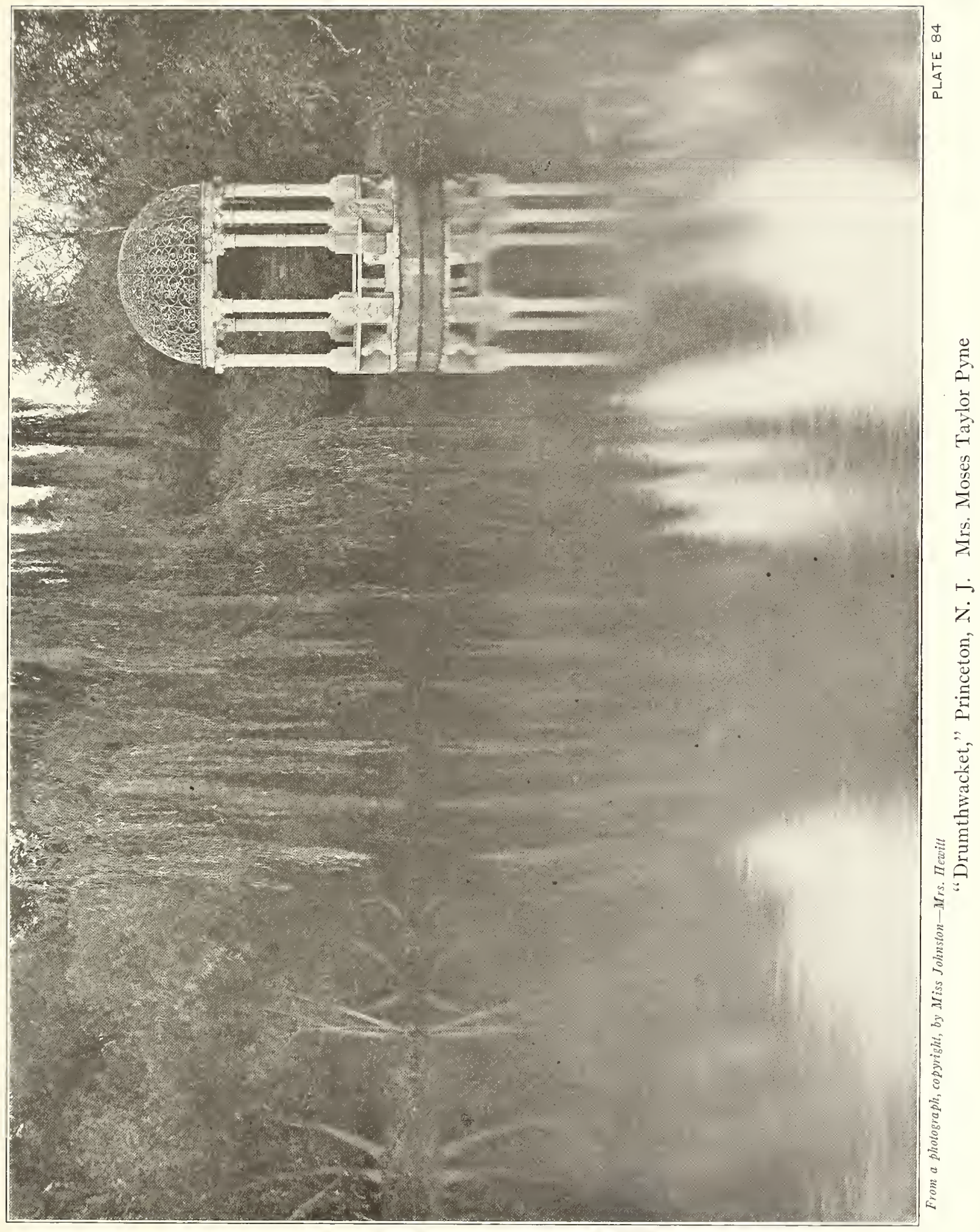





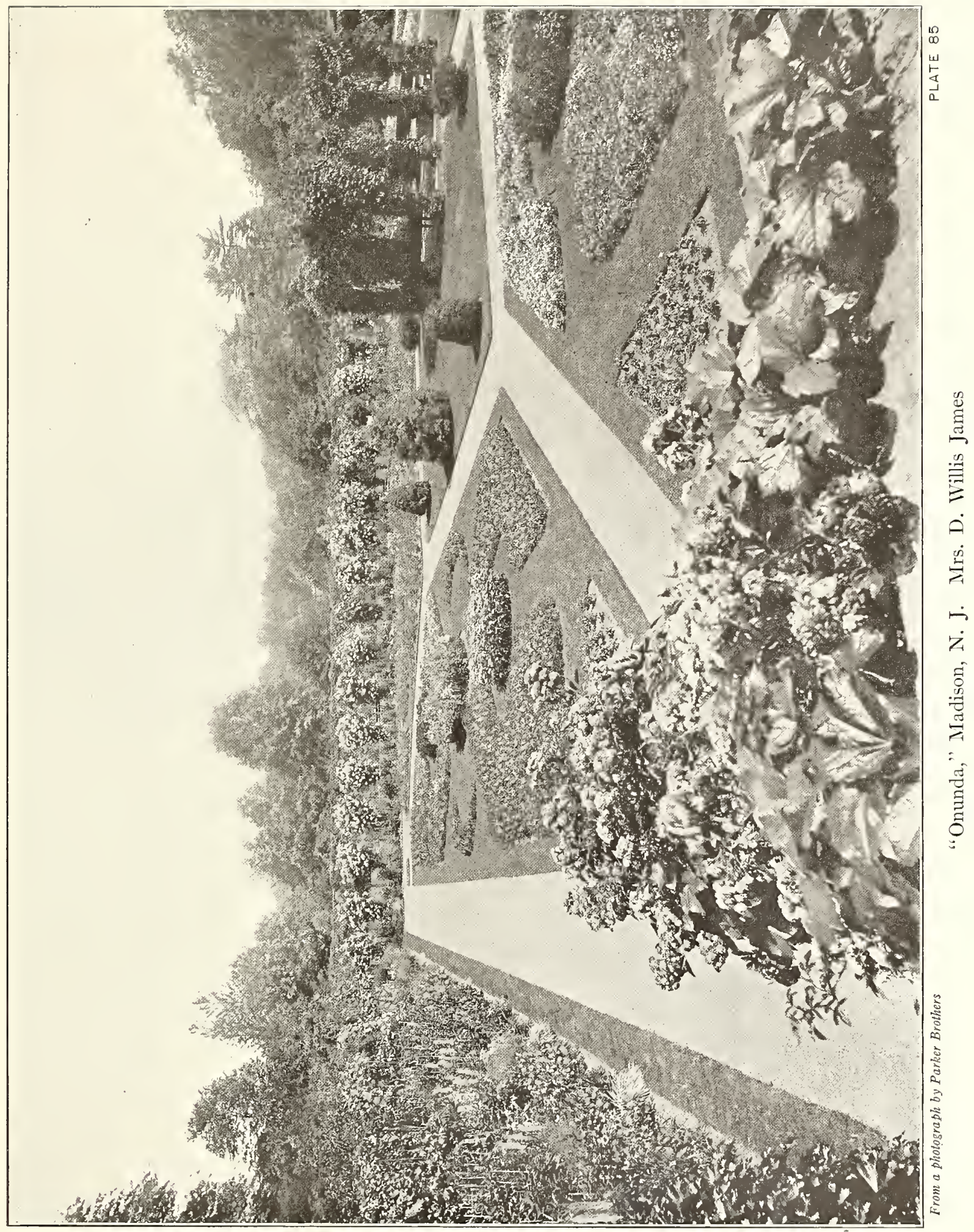





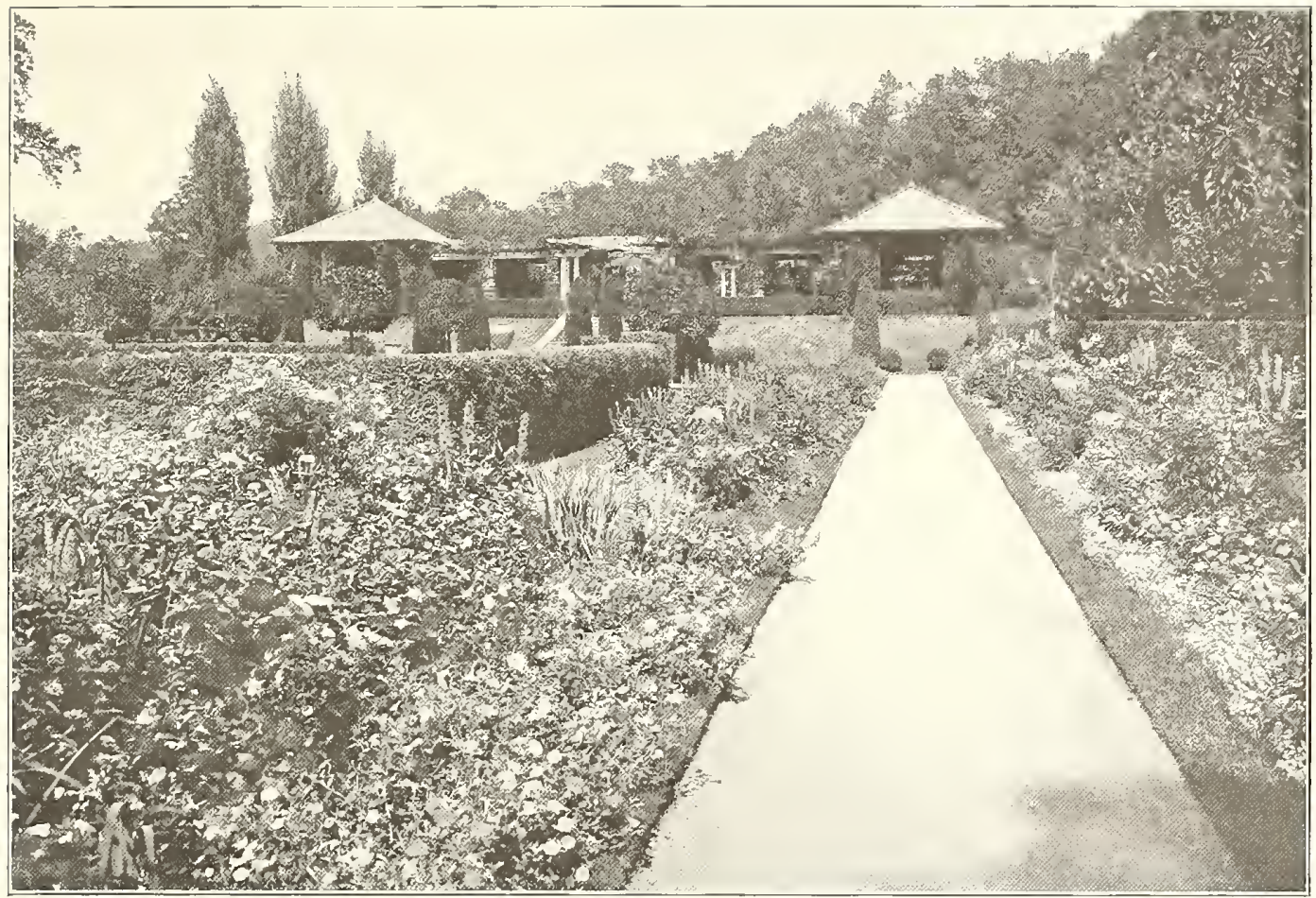

From a pholograph by Parker Brothers

PLATE 86

"Glen Alpine," Morristown, N. J. Mrs. Charles W. McAlpin

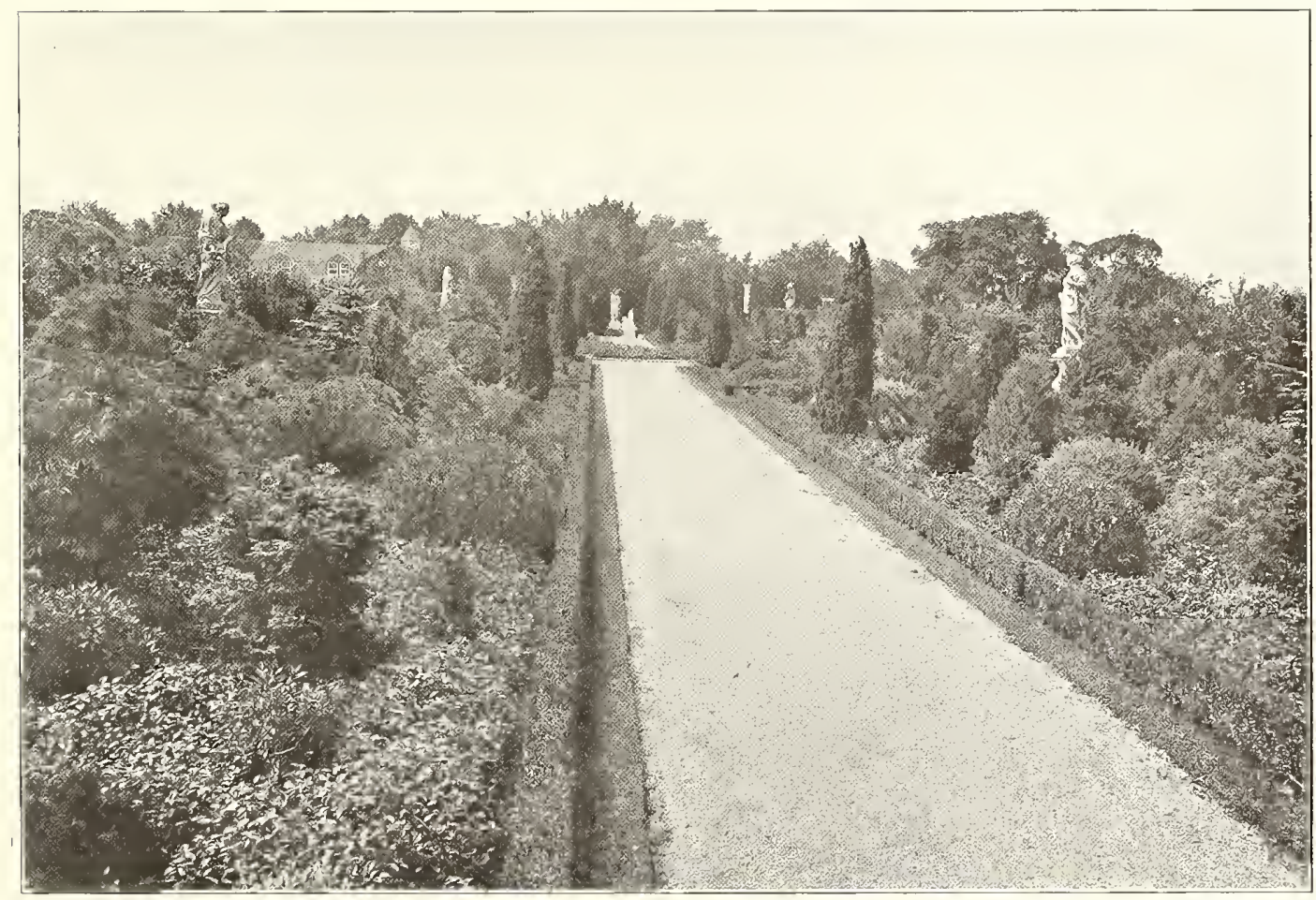

From a photograph by Alman \& Co.

PLATE 87

"Thornton," Rumson, N. J. Mrs. J. Horace Harding 



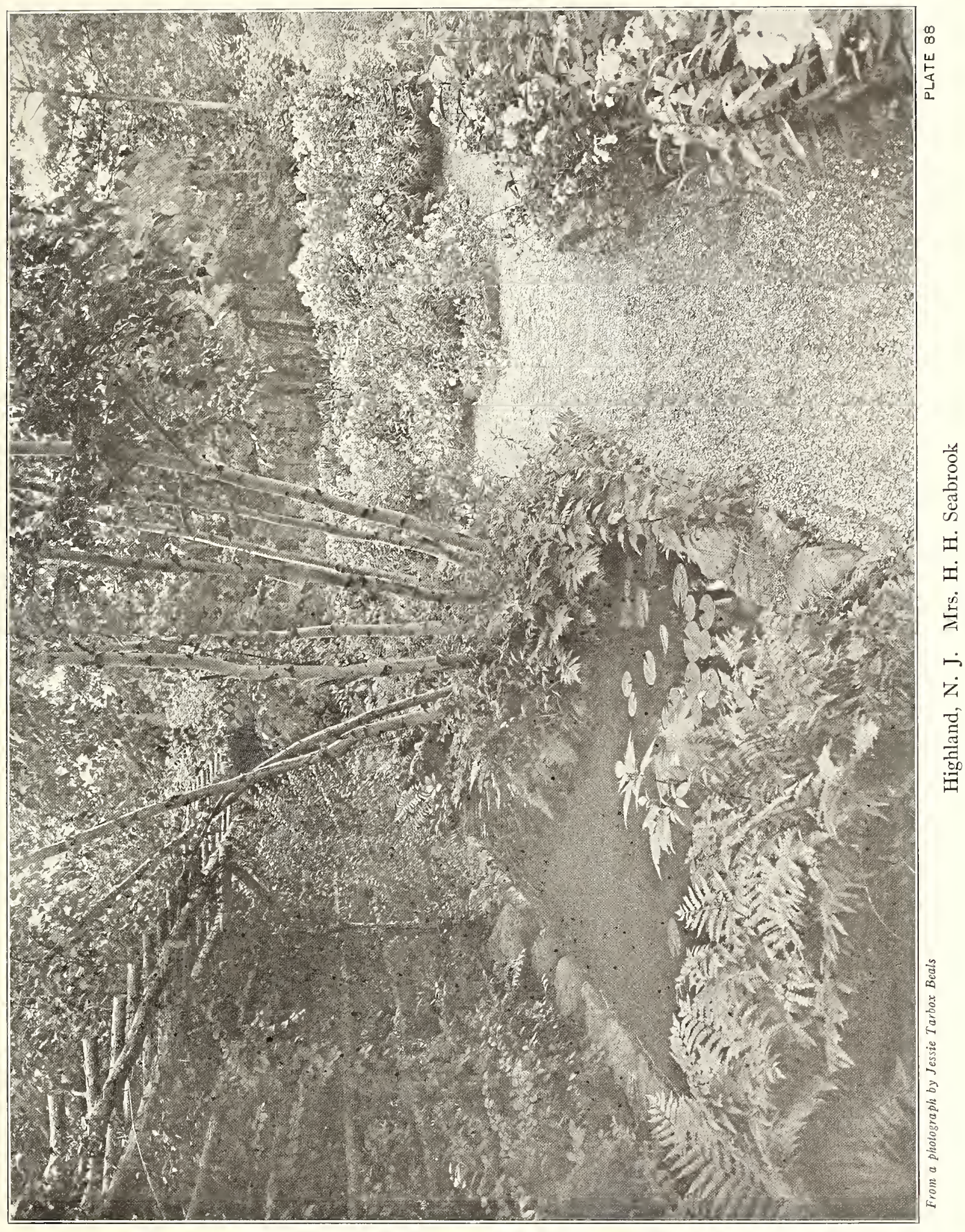





\section{VI}

\section{PENNSYLVANIA}

The most zealous advocate of gardening in the early days was William Penn, the original proprietor of the State, who persistently urged his Quaker followers to plant gardens around the homesteads. With numerous old ones and an ever-increasing number of new gardens the State stands among the foremost as a garden centre. In olden times the Quaker ideas against extravagant appearances resulted in the making of simpler places than those built by the people who settled in the Southern States; but these modest Pennsylvania gardens did not suffer the ravages of war, and many of them have lived serenely through the years.

Andalusia came into the possession of the family of its present owners in 1795, and a village has gradually grown around the place. The garden is about one hundred years in age, and has been long noted for its trees and hedges, its fruits and old-fashioned flowers. The simplicity of its plan, so characteristic of the early gardens, detracts nothing from its charm, but rather is it filled with picturesque features that are truly American.

At Fancy Field the formal garden is made somewhat 


\section{BEAUTIFUL GARDENS IN AMERICA}

on the plan of a type of small English garden that is becoming familiar to us through the English prints. This formal view is but one of a group or series of lovely enclosed and connecting gardens, all seemingly bound together by a long pergola bordering their rear; - a most pleasing study, as is also the garden at Edgecombe, with its old Box and perennials, shut in peacefully from the outer world and suggesting the type so dear to the heart of the lady of the olden time.

Krisheim was the name given by some early German settlers in 1687 to a locality where is now a famous garden. This beautiful enclosure, in its spring garb, so unique in style, and with an adjoining flower garden, has its place among the best of the many that adorn the State.

The garden at Willow Bank is a charming home of flowers, and its attraction is enhanced by the spacious green court surrounding it, giving double privacy to the flowery sanctum within.

Typical of some of the splendid newer gardens of the State is the one at Timberline, rich in its background of old trees, gracefully designed and planted. It is one of the best productions of a celebrated architect.

The Ballygarth garden, a section of which is shown in this chapter, is beautifully situated on one of the oldest estates near Philadelphia, and is of the kind so evidently the creation of a garden lover.

Near Philadelphia the climate is slightly warmer than in north New Jersey, to which spring bloom comes at 


\section{BEAUTIFUL GARDENS IN AMERICA}

least a week later. In this vicinity German Iris appears about May 15, Sweet William, May 28, and Delphiniums, June 10, Hollyhocks, June 18. The time of the first frost is as variable as it is elsewhere. Pansies are usually wintered in the open, with a certain amount of covering. Tender annuals are set out about May 10. The soil is mostly fertile enough for good results in the garden. The best-known gardens lie chiefly in the neighborhood of Philadelphia. 



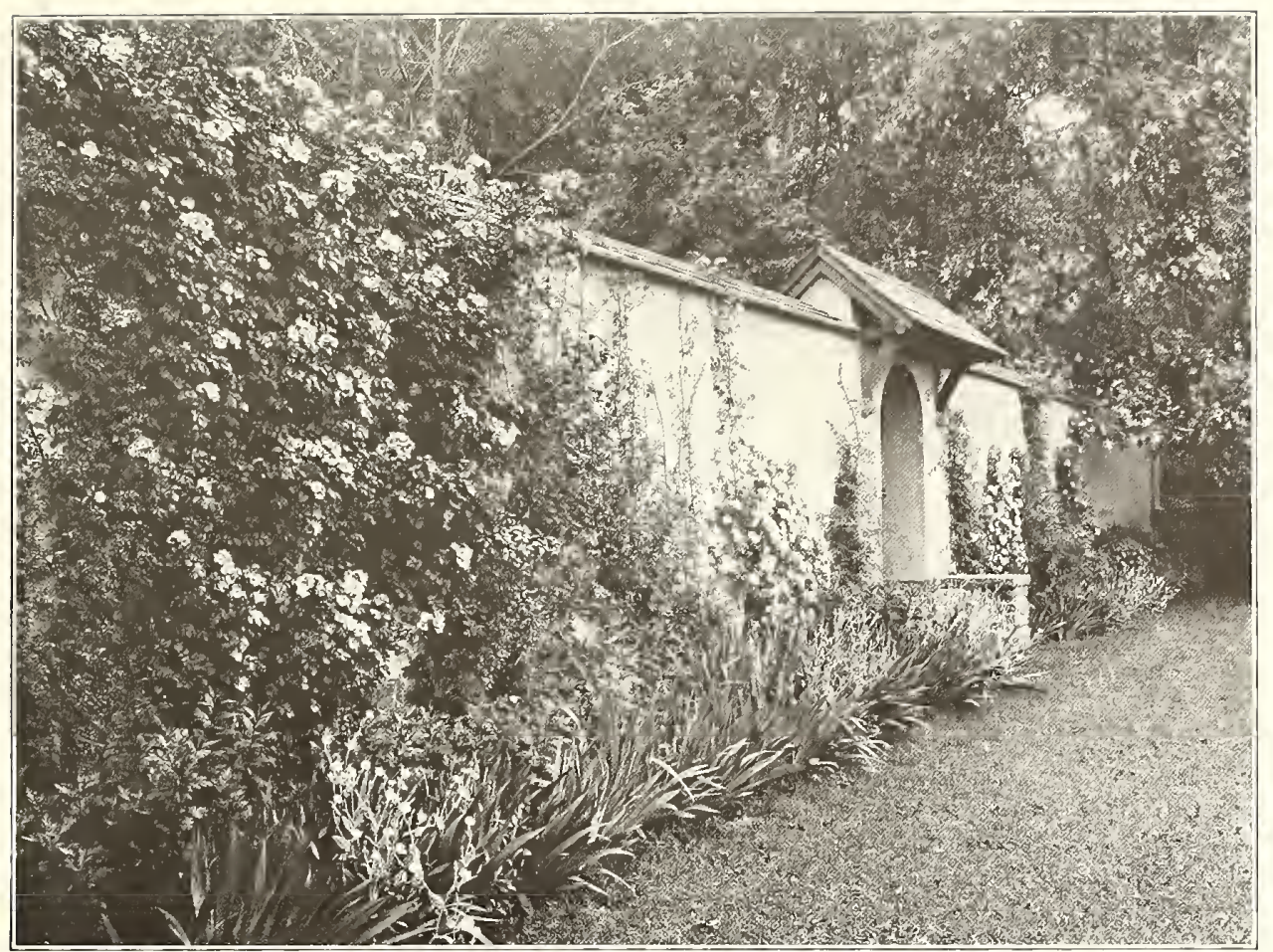

From a photograph by Jessie Tarbox Beals

PLATE 89

“Allgates," Haverford, Pa. Horatio G. Lloyd, Esq.

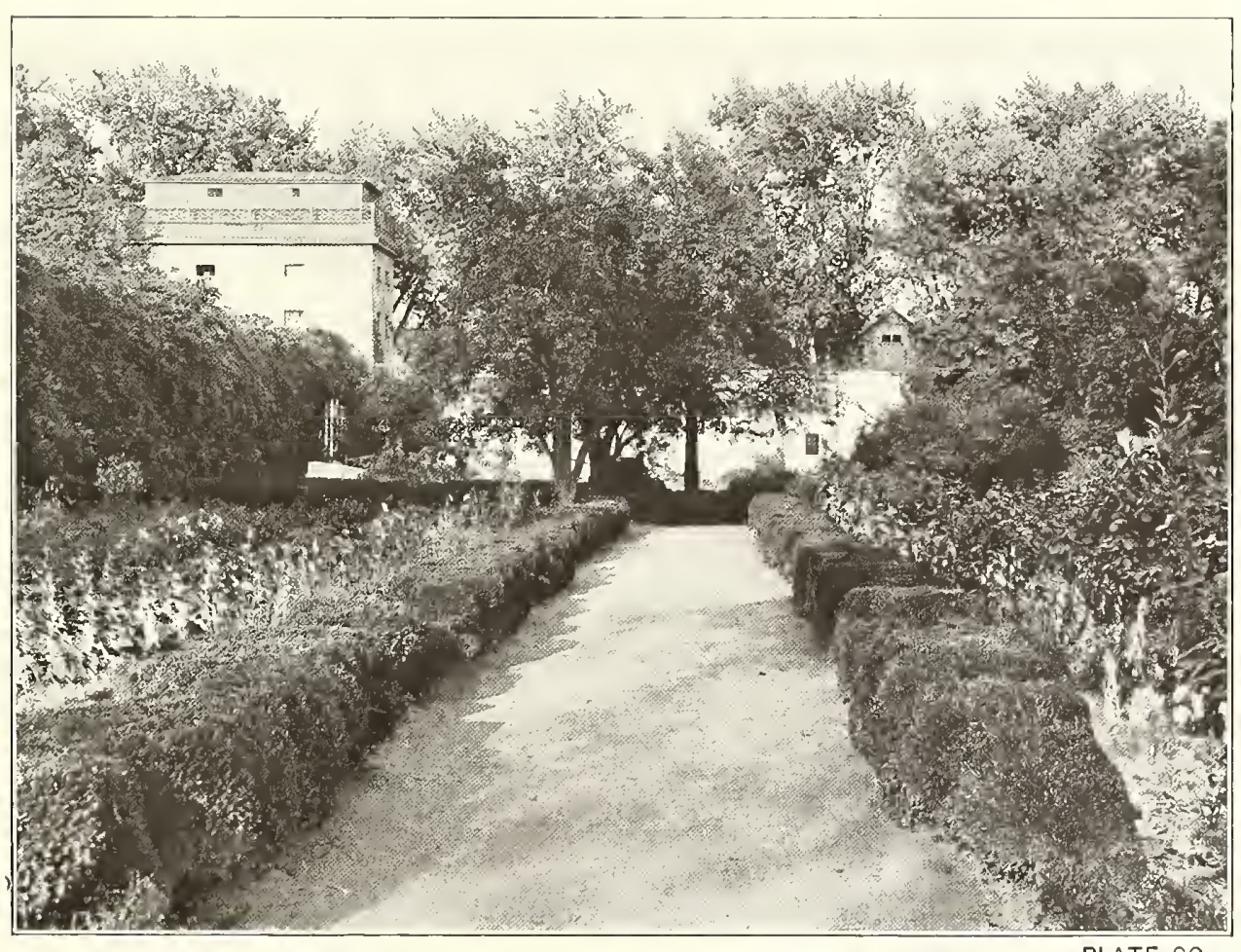

Andalusia, Pa. Mrs. Charles Biddle 



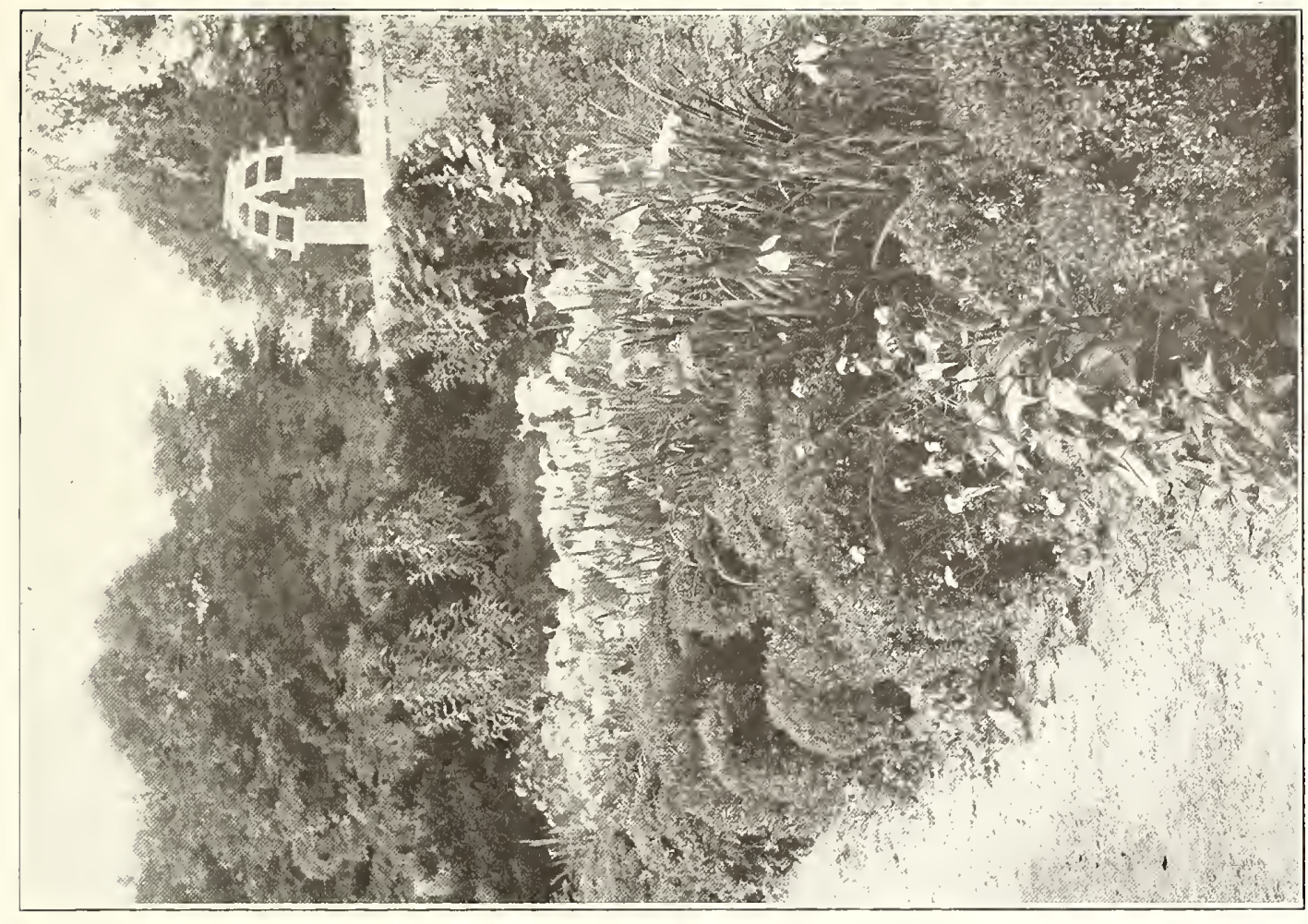

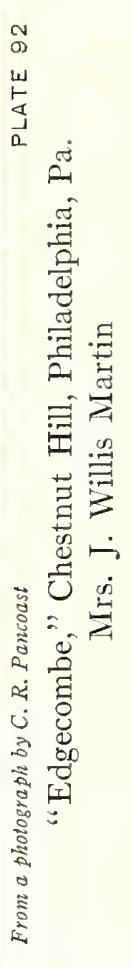

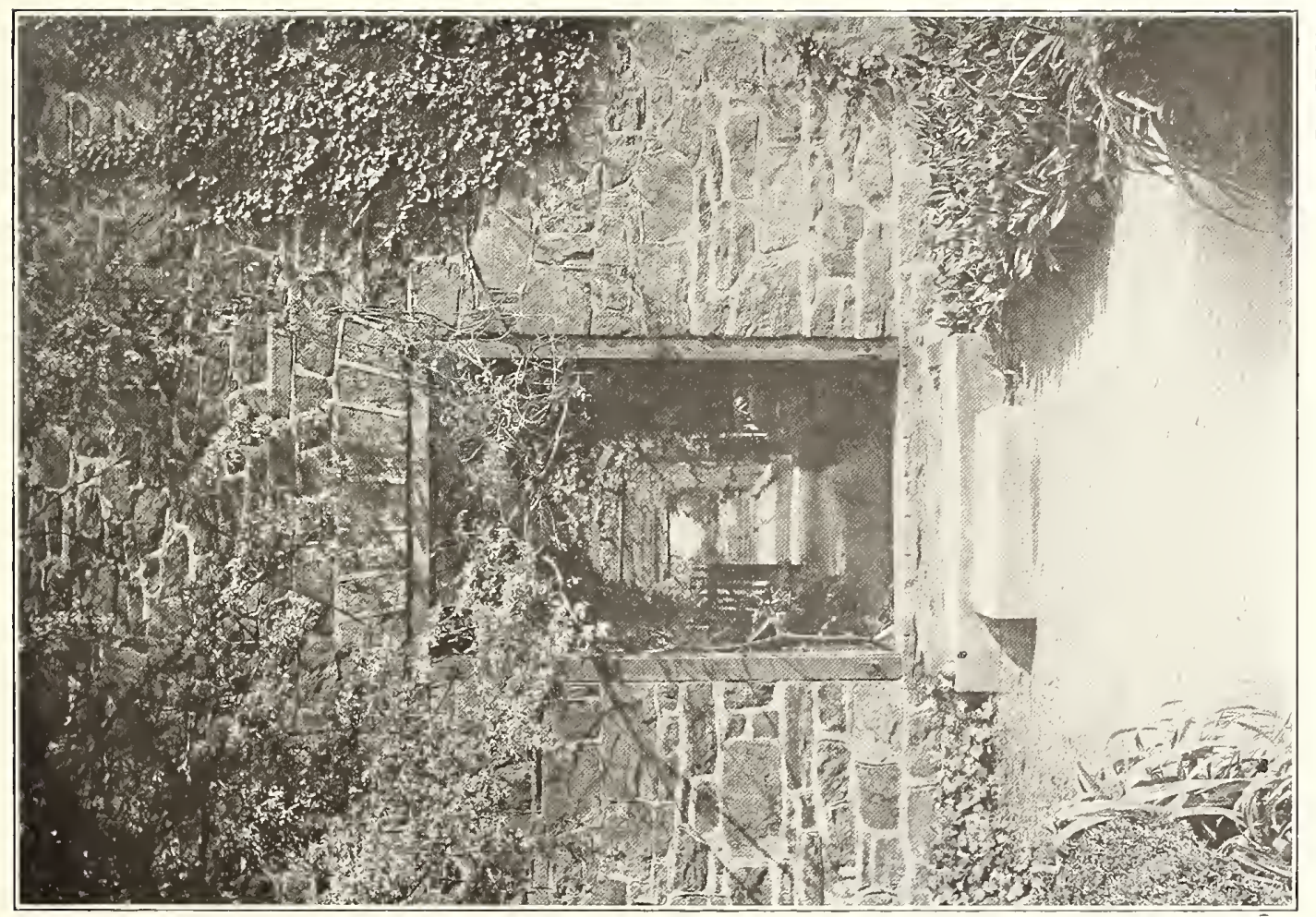

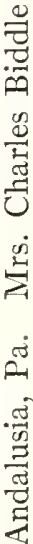





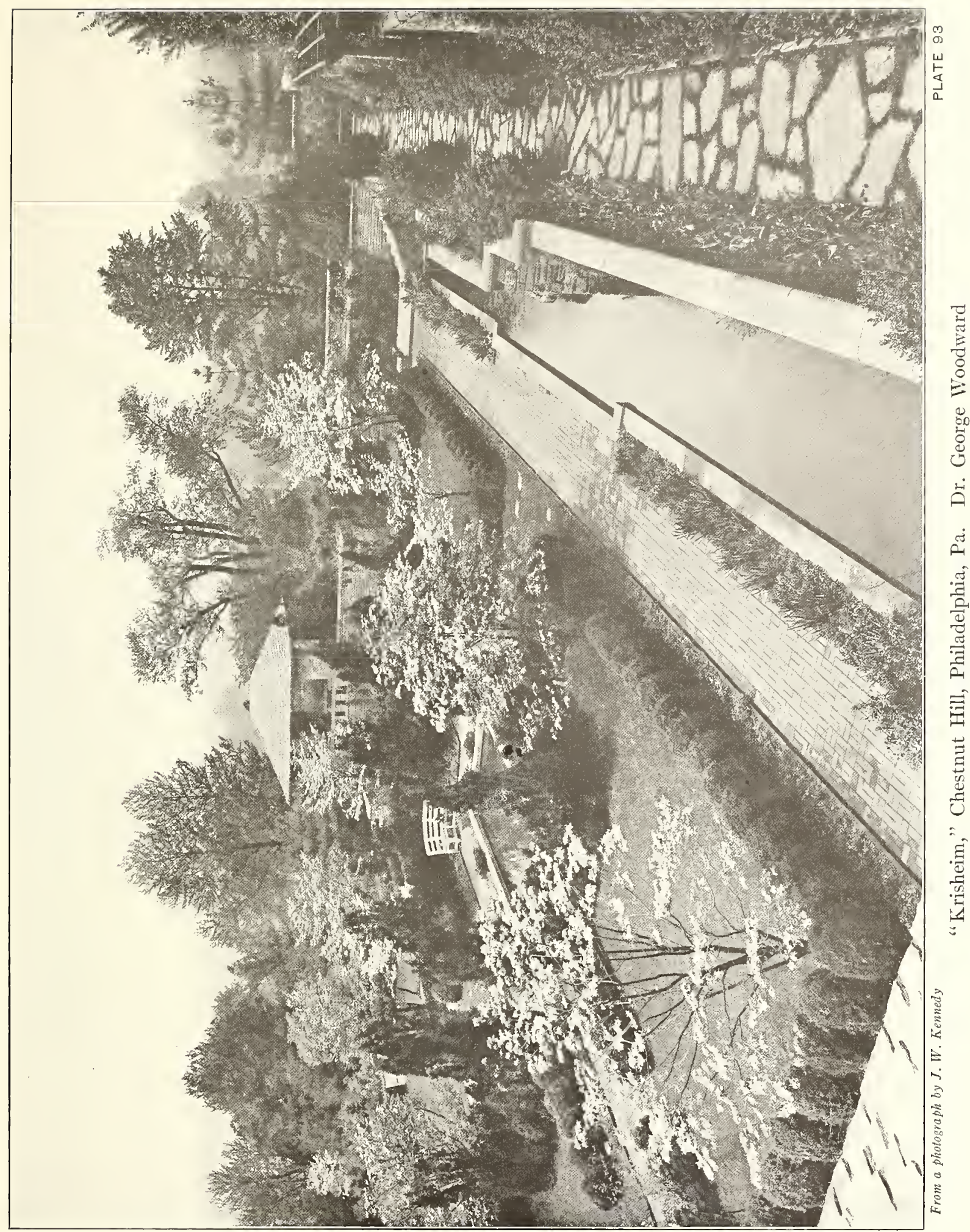





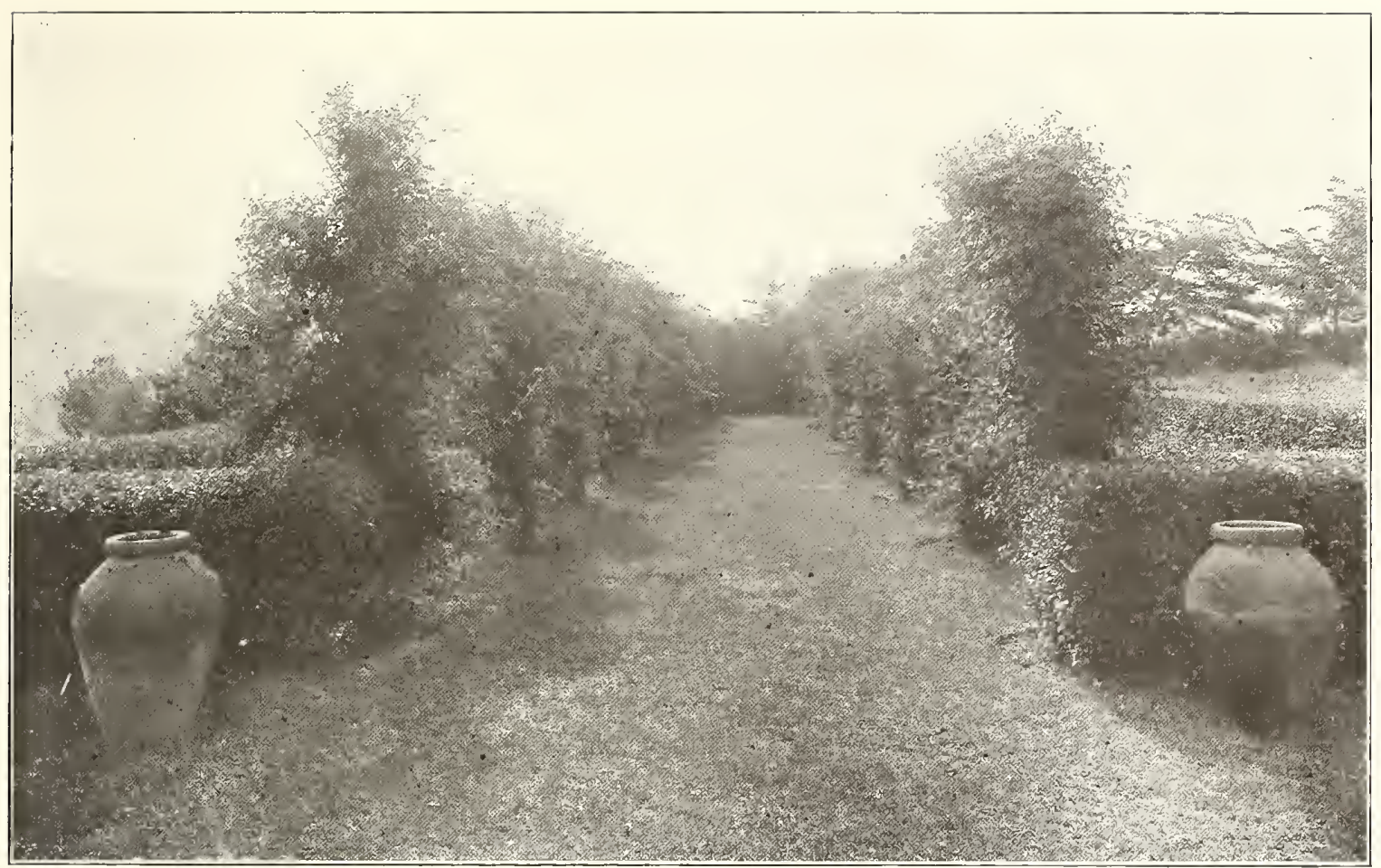

The outer court

PLATE 94

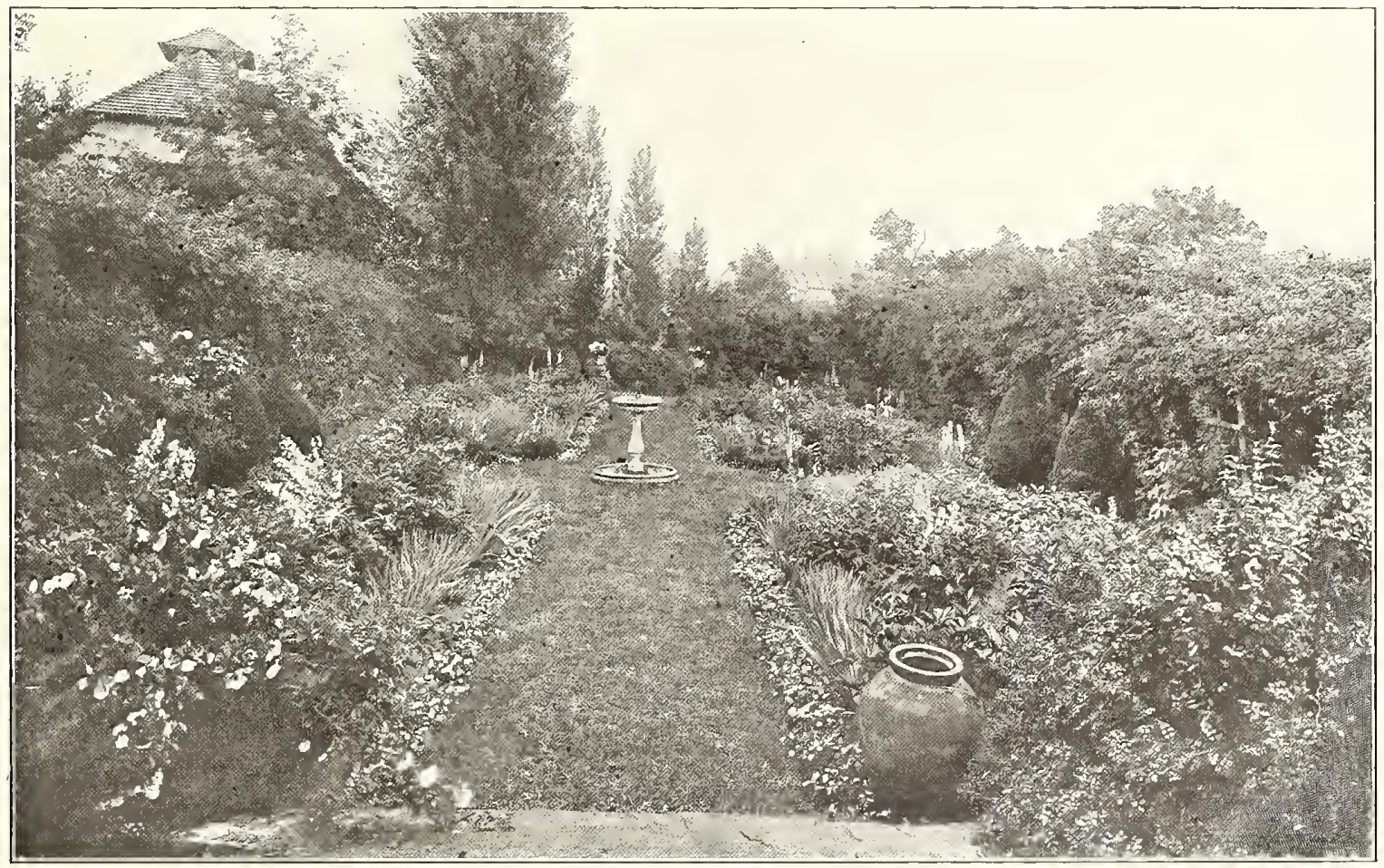

From photographs by jessie Tarbox Beals

PLATE 95

The inner garden

"Willow Bank," Bryn Mawr, Pa. Mrs. Joseph C. Bright 



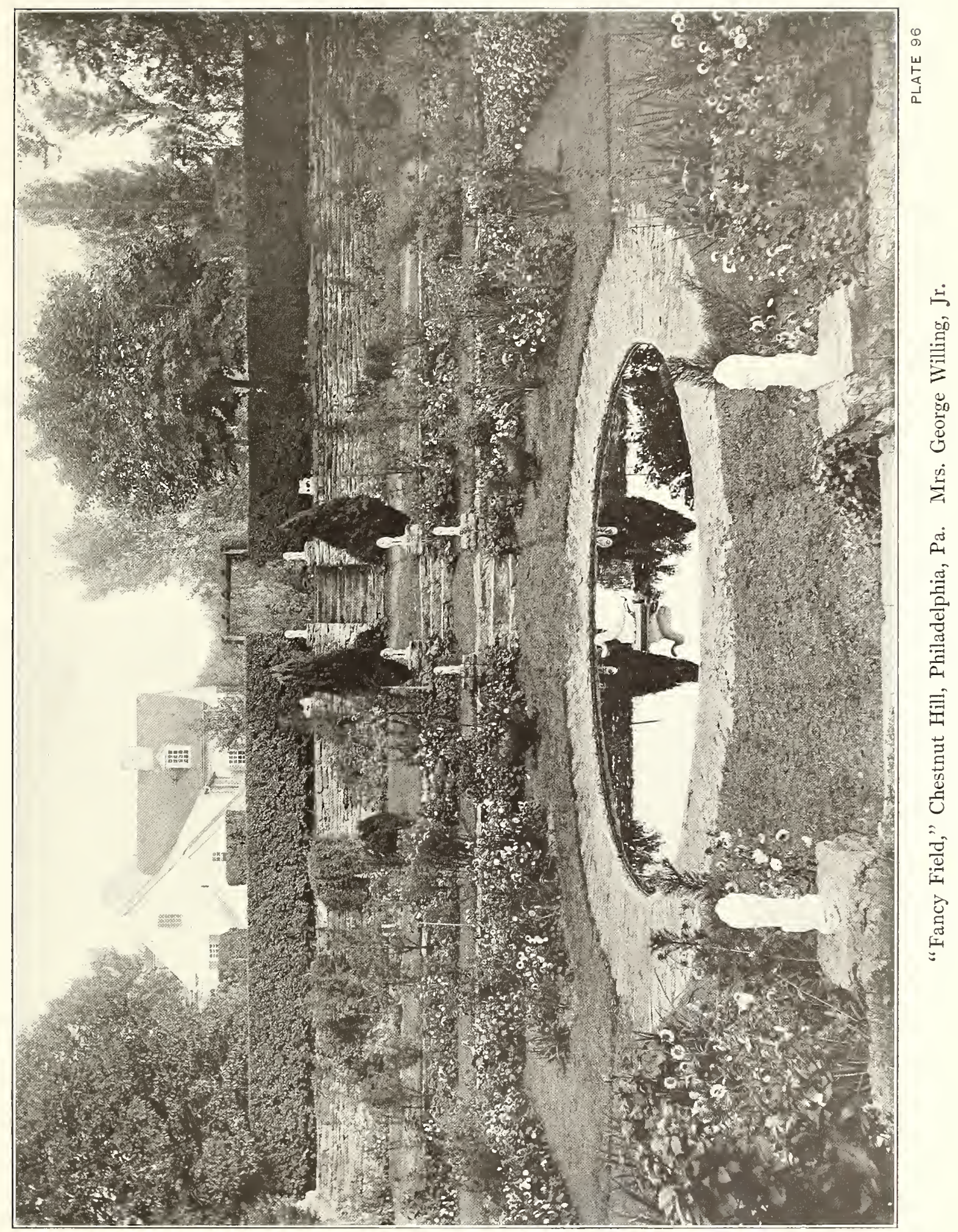





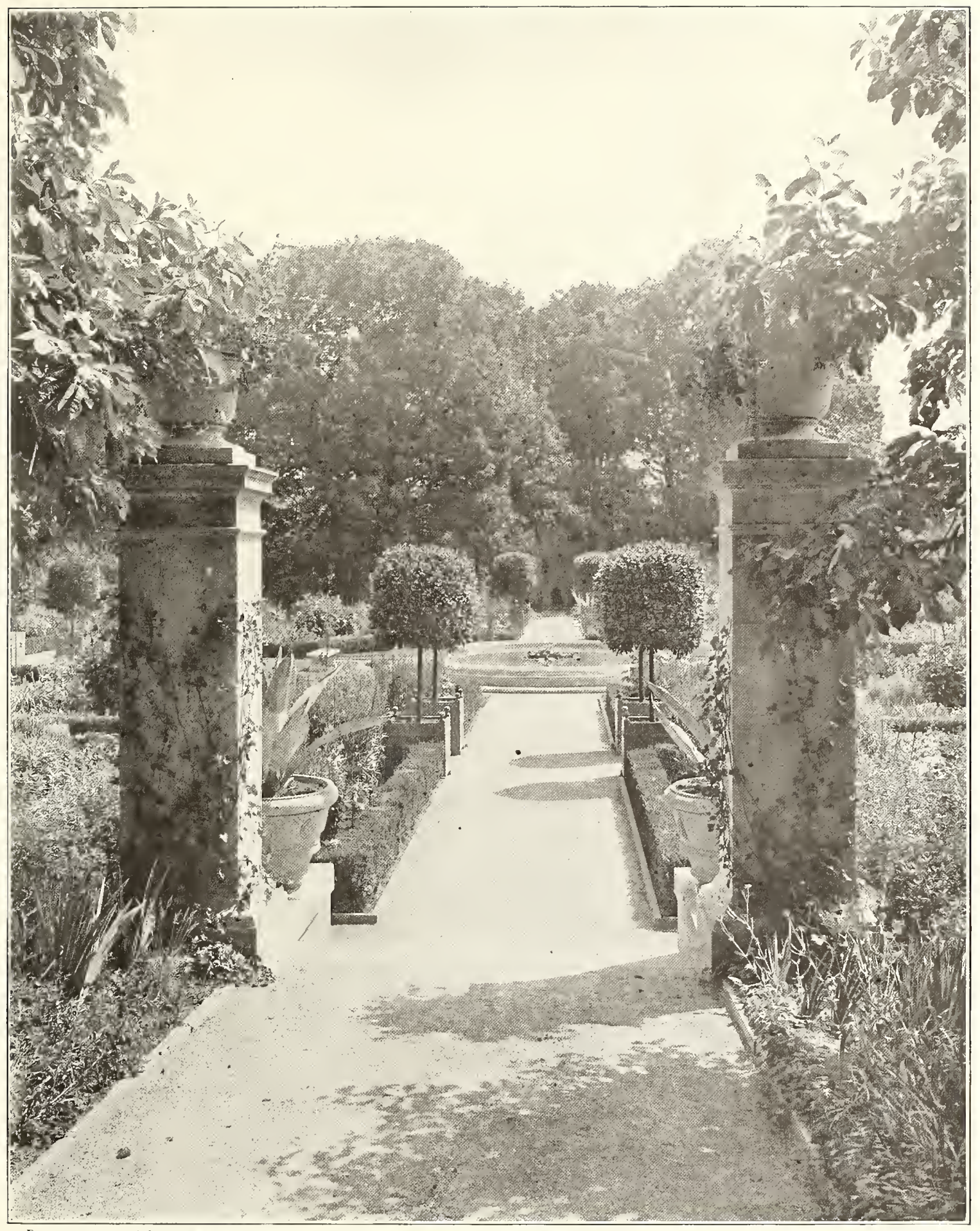

From a pnotograph by Jultan A. Buckly

PLATE 97

"Timberline," Bryn Mawr, Pa. W. Hinckle Smith, Esq. 


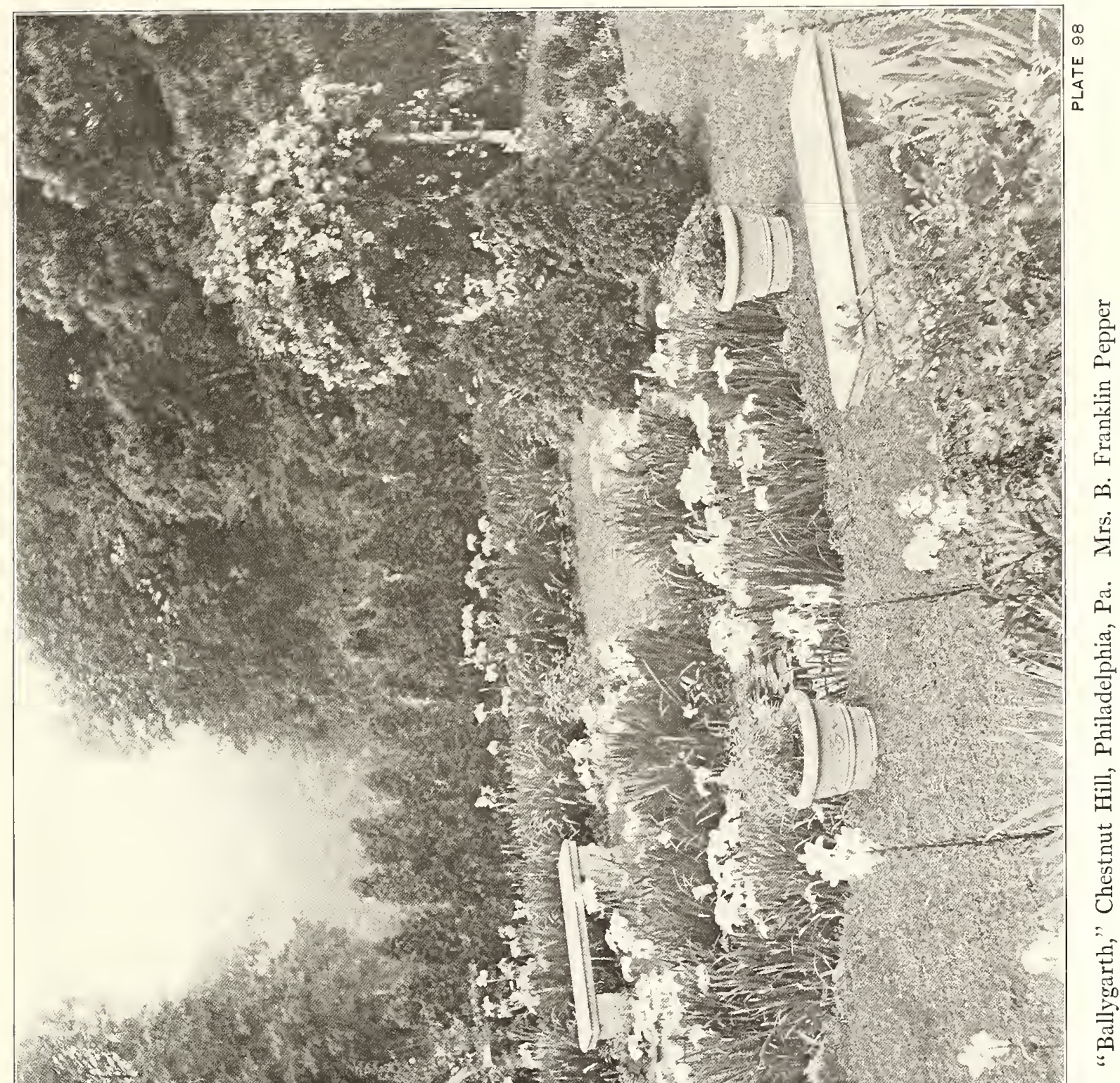





\section{MARYLAND}

Flower gardens adorn many of the places in Maryland, most of them of the old-fashioned kind so characteristic of the Southern States, and others of a more recent date. The latter, though less elaborate than those of New England, are quite as attractive in the studied simplicity of their design.

Conspicuous often are the Ivy-edged paths sometimes replacing the low Box border, and the great growths of Box and rare shrubs, once imported luxuries from old England, speak the prosperity of early days.

In the low country of the interior the midsummer climate is humid and hot enough to discourage the flowers of this season, but when certain annuals are kept sufficiently moist and mulched they may pass unscathed through the trying season and join the few fall perennials for several weeks of bloom.

Winter protection is not a matter of importance and Pansies need but an ordinary covering of leaves. An extreme of cold, which is rare, might bring disaster to the leaf-covered Canterbury Bell in the open, but this is one of the gambles in garden life. 


\section{BEAUTIFUL GARDENS IN AMERICA}

In Maryland, as generally elsewhere in this section, spring and June gardens prevail. The Crocus season opens in early March; Daffodils follow a little later; late Tulips and German Iris come near May 1; Sweet William and Peonies about May 20; and soon after the Delphiniums and Hollyhocks appear. Spring work begins three weeks earlier than in the latitude of Long Island, and frost may finish the persistent Marigold near November 1; but, as elsewhere, by that time green life has had its day, vitality has been spent, and nothing satisfactory can be expected of any but the hardy late Chrysanthemum.

There is another region of this State to be separately accounted for that has been more or less overlooked, and where the climate is more inviting to summer gardening. From near Snow Hill, on the narrow peninsula south of Delaware, a resident writes in part: "As to this eastern shore, its flowers, climate, etc., too much cannot be said in its praise. The wonder is that this section has been overlooked by wealthy people seeking homes. With proper planting one can have flowers in the garden ten months of the year. During the winter Holly and other choice evergreens give plenty of color for the lawns." The distance across between the Chesapeake Bay and the sea is about thirty-five miles. Near the shore the place has a climate of its own, and summer gardens need not wilt as they do inland, providing they can at times be moderately sprinkled. Usually the summer climate is pleasant with an evening sea-breeze in hot weather; some- 


\section{BEAUTIFUL GARDENS IN AMERICA}

times a prolonged dry spell causes many things to suffer, but as a rule all sorts of flowering plants succeed - Roses, China Asters, and bulbous plants especially grow to perfection.

The illustrations representing Maryland are gathered from the vicinity of Baltimore, the particular garden region of the State. Hampton is the oldest of them all, being an entailed estate and one of two old manor-houses in Maryland still extant. A severe cold snap a few winters past did great damage to the Box, which in consequence had to be cut back, but time, it is hoped, may restore its original form and beauty. The spring view of one of Hampton's gardens was taken recently prior to the period of fullest bloom. This charming Box-edged parterre, with its fine surroundings and associations, is possibly the best-known in the South.

Evergreen-on-Avenue is delightfully located on the outskirts of Baltimore, where many old country-seats abound. The lower garden only is discernible in the illustration, showing the dignity and charm of an evergreen garden, relieved by a massing of color in narrow beds which form a setting to the clipped Box and other shrubs. The upper garden is full of bloom and kept chiefly as a place for cutting-flowers. Some of the paths on this estate are edged with broad bands of Ivy.

The wild garden at Roland Park is a work of art too intricately devised to be treated satisfactorily by picture or pen. The eye can only absorb and memory retain it, 


\section{BEAUTIFUL GARDENS IN AMERICA}

but description will ever fail to present it. At every turn there is a delightful surprise, at every season it is lovely; even January finds it so dressed in evergreen that winter seems far away. A few years ago the hillside was a wooded and abandoned stone-quarry until purchased for the purpose of creating a place of beauty out of chaos. An inspired imagination only could have wrought this miracle.

The old Indian name for the Cylburn plantation was Cool Waters; it covers two hundred acres, about five miles beyond Baltimore. Cylburn House is of stone with broad verandas, and stands majestically on a high plateau, surrounded by gardens, shrubbery, and an extensive lawn, which is fringed by a beautiful primeval forest that stretches away on three sides to the valley below. The garden is one of the old-fashioned rambling kind, made lovely with a combination of tall shrubs and flowers and occasional trees.

The fair little glimpse of a section of the garden at Ingleside breathes of spring perfume and color, with that indescribable sense of peace pervading especially a little enclosed garden where good taste and harmony prevail. So great is the impression of seclusion produced by the attractive picture that the farmer's cottage in the near background seems almost disconnected from this inviting spot. The four white standard Wistarias are remarkable enough to demand special attention. The beds are early filled with the Tulips of both periods, blooming in com208 


\section{BEAUTIFUL GARDENS IN AMERICA}

pany with the Wistaria. Annuals follow, and the place is kept in long bloom under the careful supervision of the owner.

At The Blind, Havre de Grace, on the Chesapeake, is a charming and typically Southern garden with ancient Box hedges for a background, and filled with the bloom of many old-fashioned hardy plants and shrubs. The property of two hundred acres is partly under cultivation and partly covered with Holly and ancient trees. Around the gray stone mansion in springtime the place is like a fairy-land, with hundreds of blossoming shrubs and fruit trees. Originally the land belonged to the Stumpp family, who acquired it by grant from one of the early English governors. It is now in the possession of a New Yorker, who keeps it as a shooting-preserve and stock-farm. 


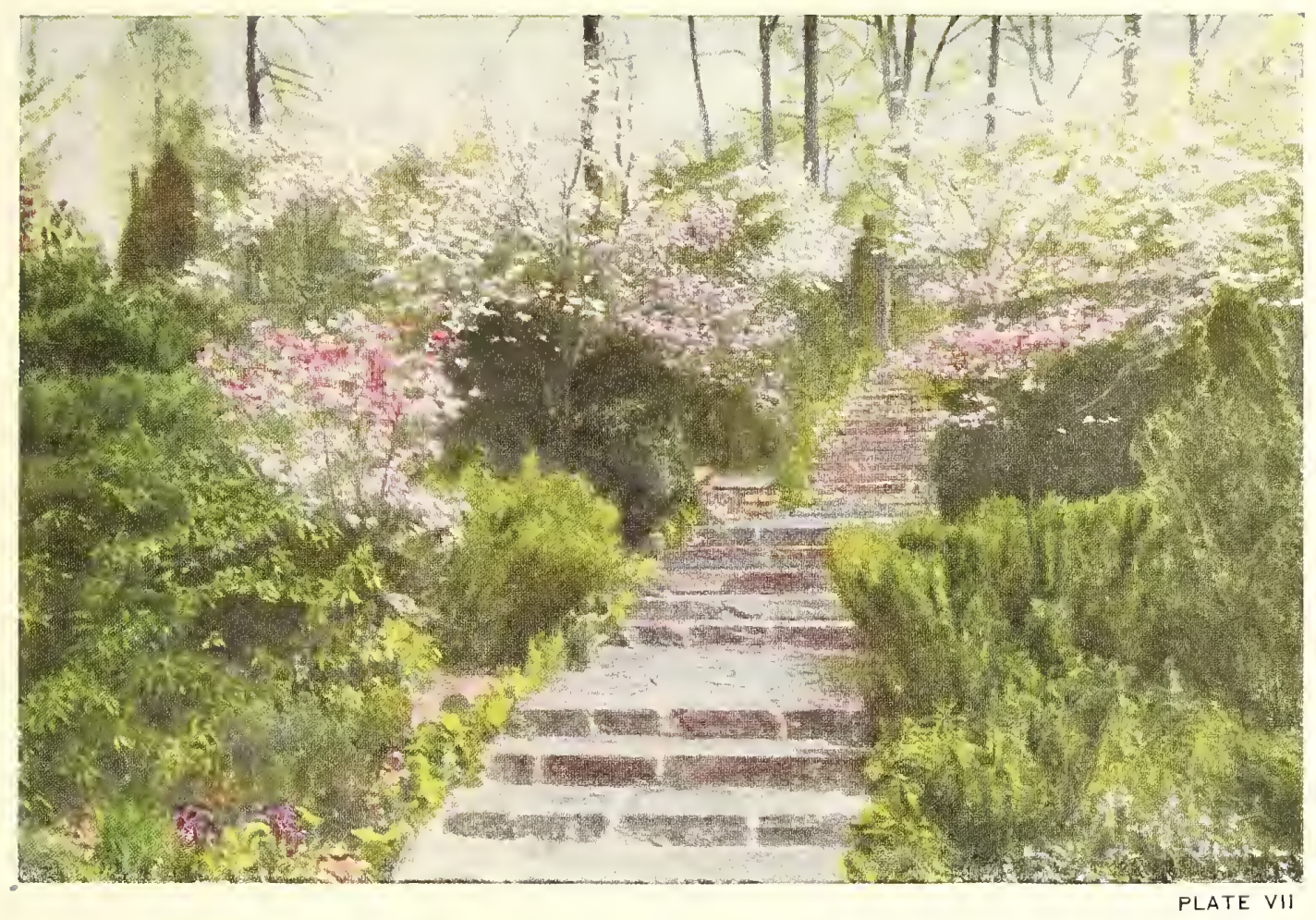

A rock garden

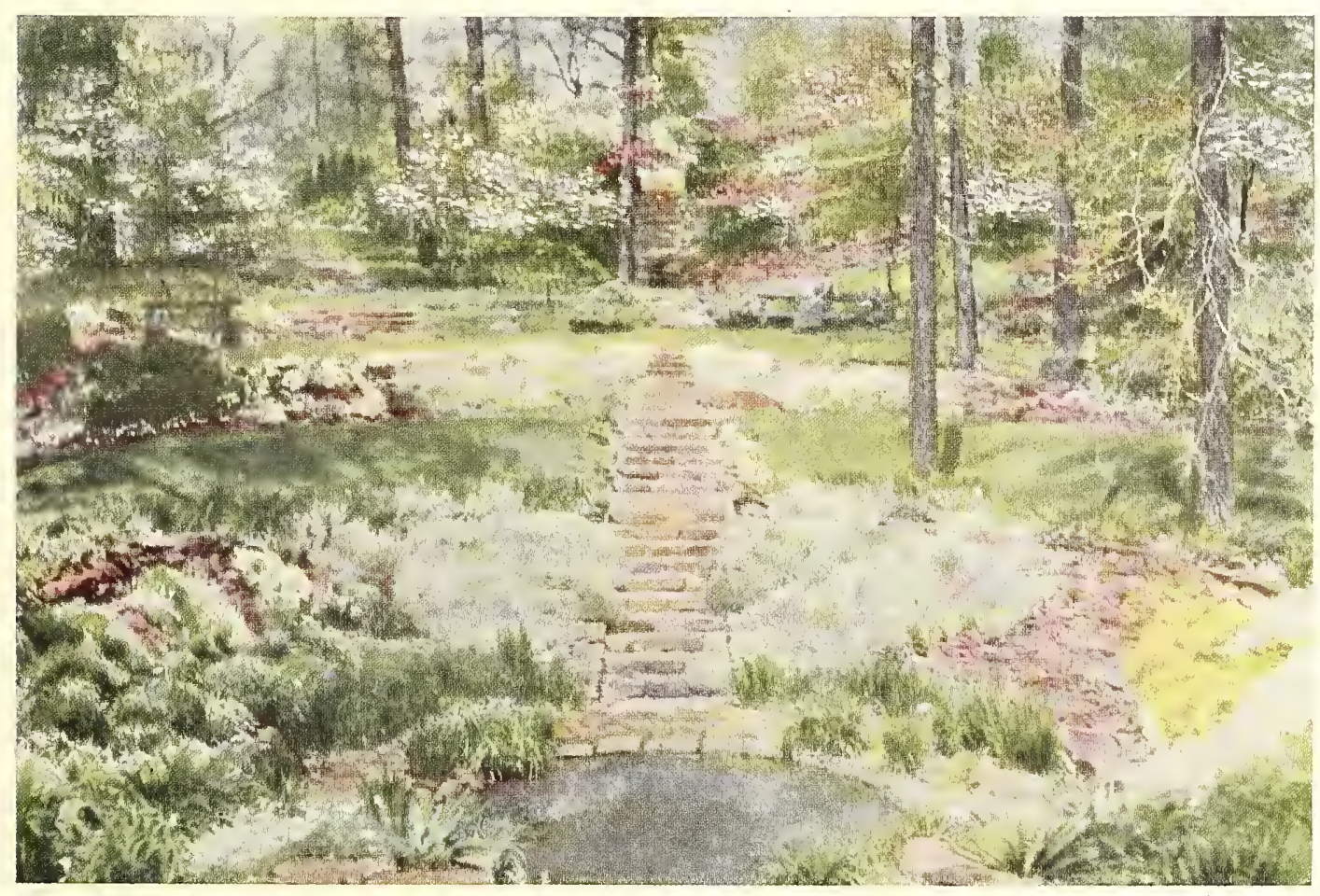

After autochrome photographs

PLATE VIII

A rock garden

Roland Park, Baltimore, Md. Mrs. Edward Bouton 



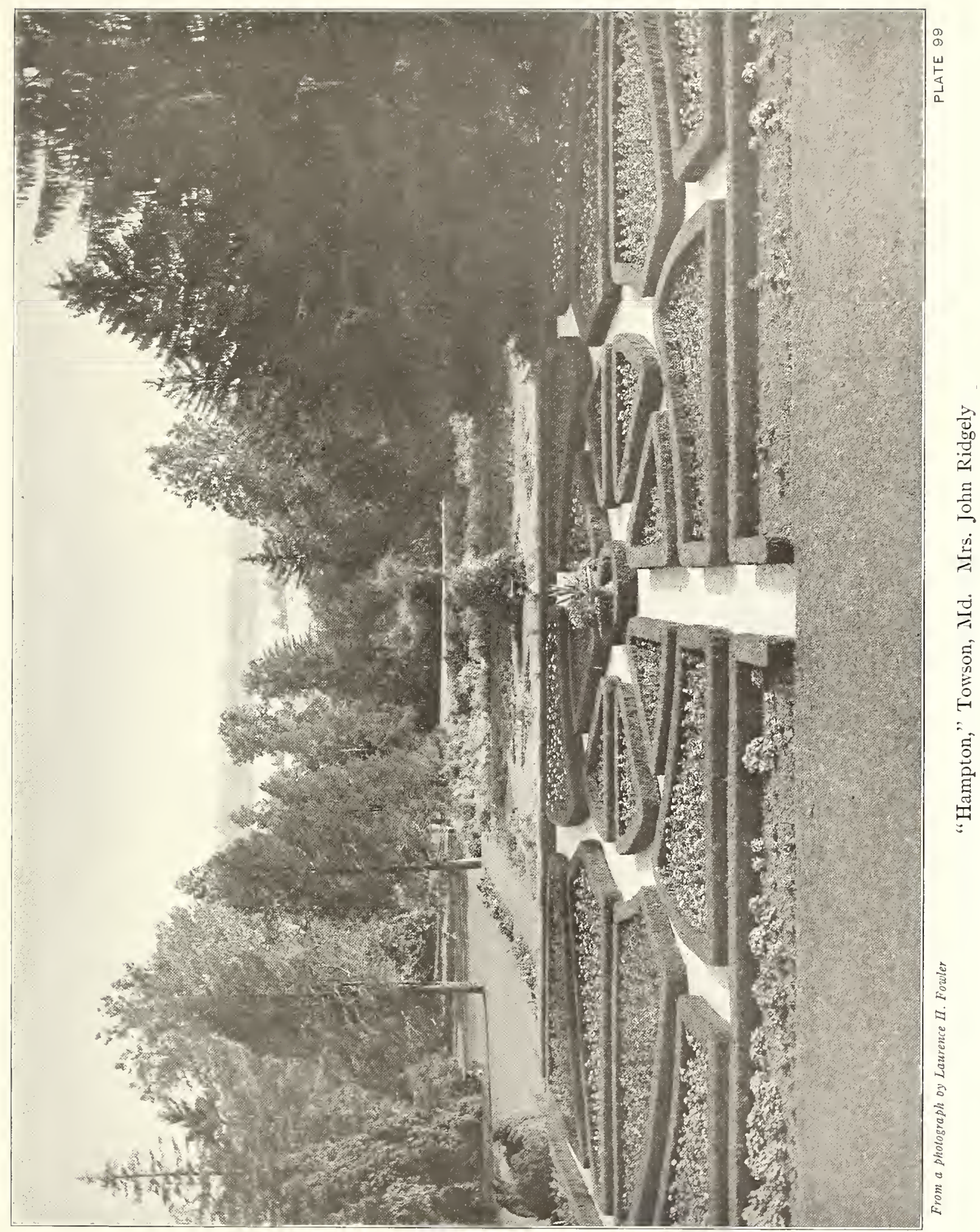





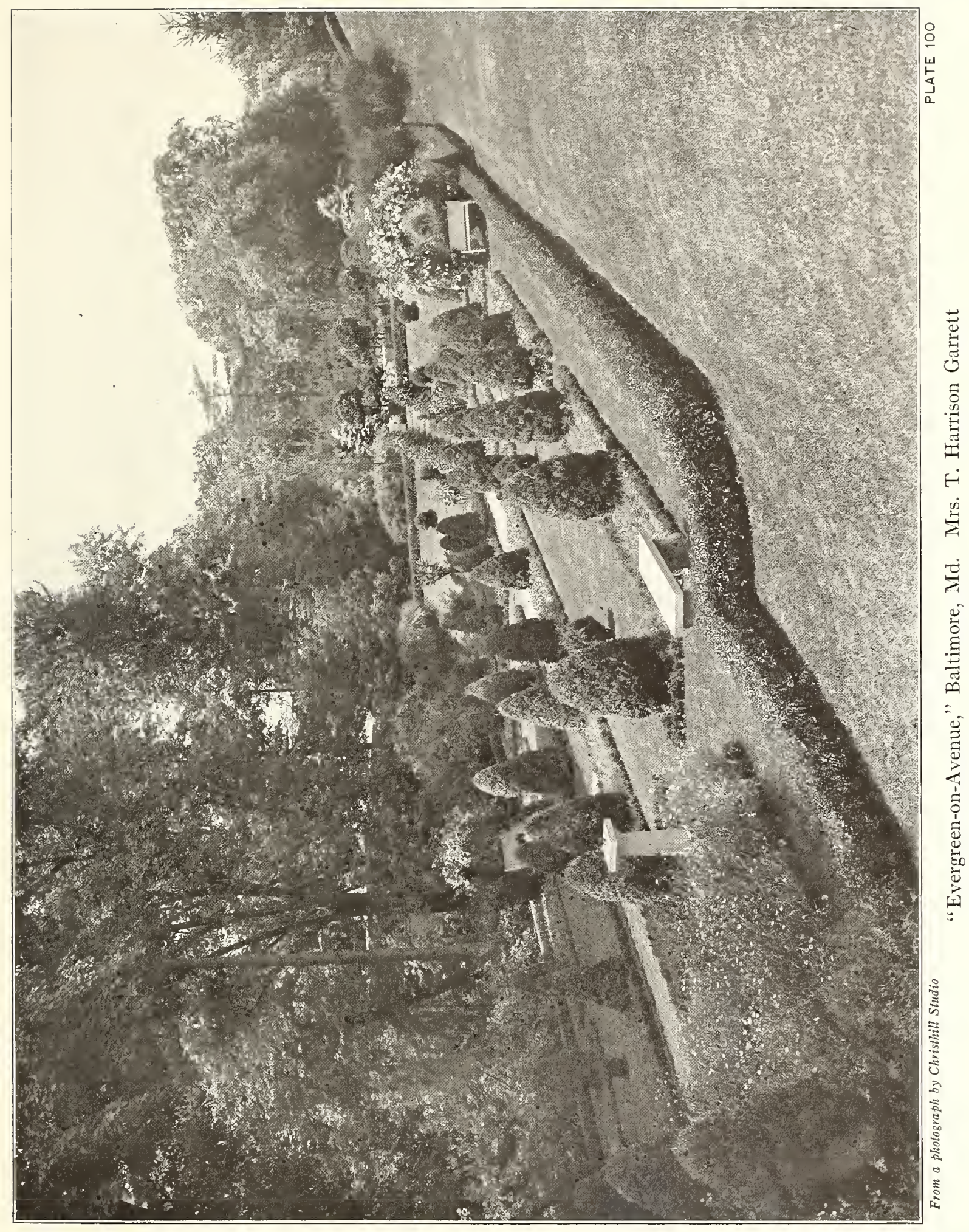





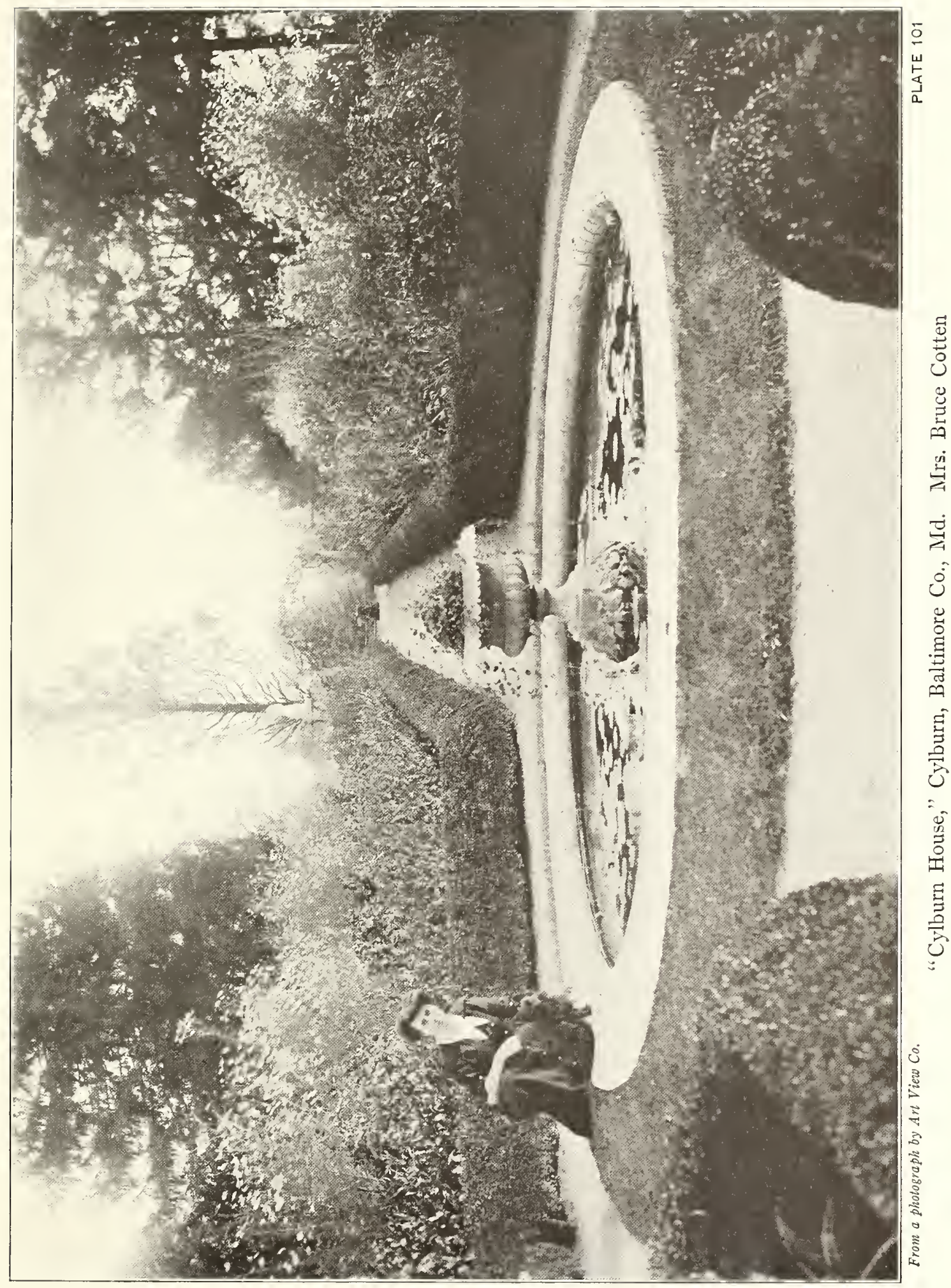





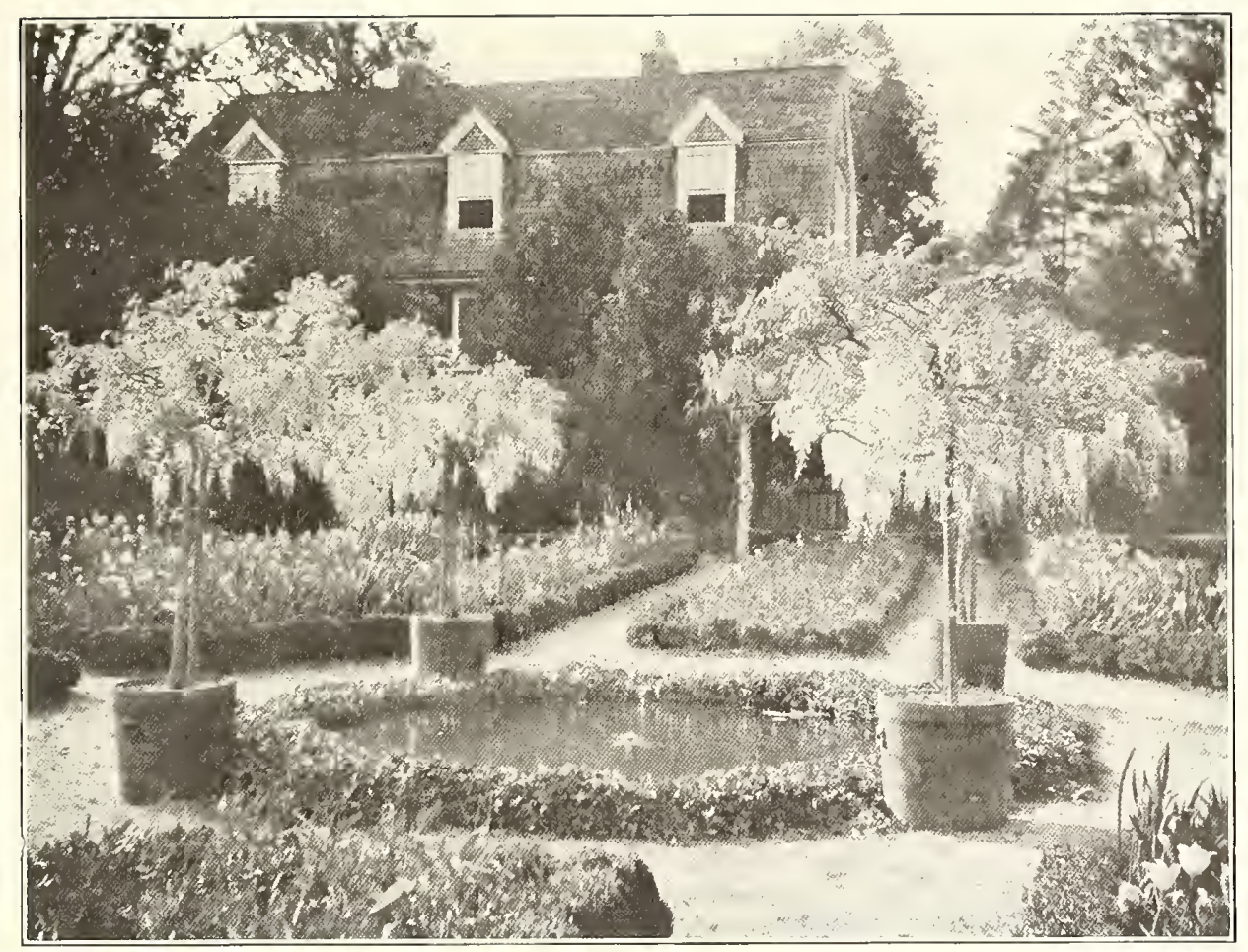

PLATE 102

“Ingleside," Catonsville, Md. Mrs. A. C. Ritchie

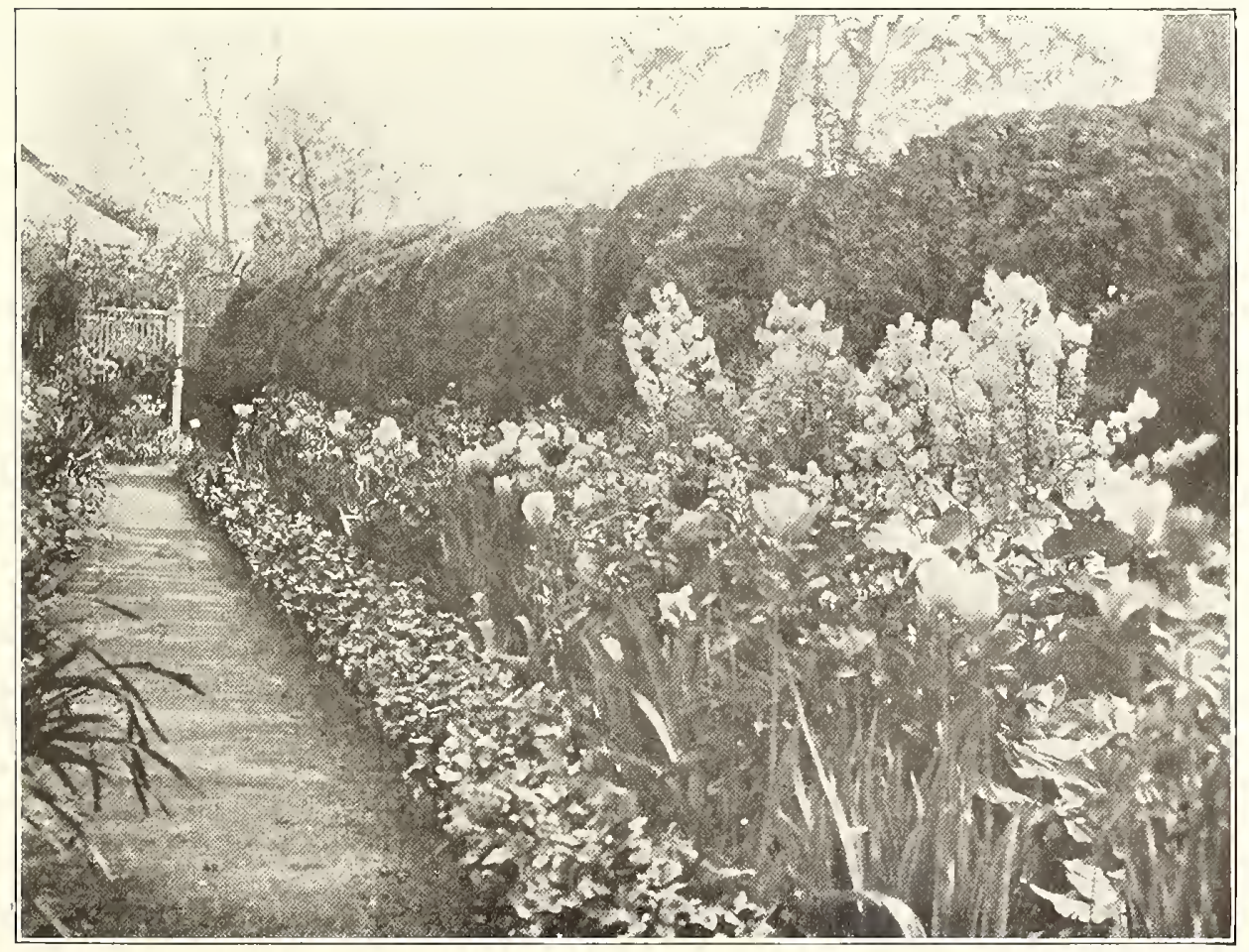

PLATE 103

"The Blind," Havre de Grace, Md. James Lawrence Breese, Esq. 



\section{VIII}

\section{VIRGINIA}

Virginia was the first of the States to adopt a luxurious mode of living. Its early men and women, so recently English, were not many of them of the strictly Puritan type, but rather the ease and pleasure loving class, and shortly their fertile plantations, developed by countless slaves, yielded rich results, and Virginia, followed soon by the neighboring States, became famous for homes and gardens on an extensive scale.

One of the earliest and best of these estates was Mount Vernon, so well preserved and yet so familiar as not to need an introduction or even a space in this book. Brandon, Westover, Shirley, Berkeley, Castle Hill, and others on the River James, as well as some of the splendid places in the "hill country," have been renovated in recent years and should be considered among the treasures of America.

Mr. William du Pont is the fortunate present owner of Montpelier, the home of President Madison, in Orange County, and situated between Charlottesville and Richmond. This splendid garden was planned by Mr. Madison soon after 1794. To quote Mr. Capen:* "On the plan

* "Country Homes of Famous Americans." 


\section{BEAUTIFUL GARDENS IN AMERICA}

of our House of Representatives, it is made in a series of horseshoe terraces leading down to a flat rectangular stretch of ground. The walk from the entrance to the garden passes first under a charming rustic arbor, and then through a dense Box hedge in which some of the bushes have grown so high that their branches form an arch overhead .... and when one emerges from the arch of Box he finds spread before him in panorama the entire garden ... the Box-edged aisle down its centre and every bed in flower. . . . It must have been a rare garden, for trees and shrubs sent to Mr. Madison by admirers from all over the world were jealously guarded and nurtured."

At Rose Hill the terraced garden, with its distant view of hills and valley, is among the best-known places of this section. Here the flowers, most carefully tended, bloom considerably during the period from April to October, which is unusually prolonged for a Southern garden. Flowering plants and clipped evergreens border the broad, grassy terraces and an air of simple stateliness pervades this charming Virginia garden.

Delightful indeed is the spacious formal garden at Meadowbrook Manor, on the James River. So cleverly arranged is the combination of trees and flowers that the latter do not suffer from near association with the trees many of which are evergreens combining with the Box border to gladden the winter garden with summer green, and giving the livable, homey sense to this lovely enclosure 


\section{BEAUTIFUL GARDENS IN AMERICA}

in summer-time. In the old days the property was known as Sequin and belonged to relatives of Sir Thomas Gates of the same name. Upon this land in 1619 were operated the first iron-works in the country.

Characteristic of the gardens of the older period is the lovely view of the garden on the Valentine place overgrown and ripe as only a garden can be that has lived through the years; unpretentious, yet richer in that mellowed growth than the most costly planting of modern date.

In Virginia, mountains cover a part of the State, and the temperature necessarily varies according to locality. The climate, at least of Albemarle County, brings out the Crocuses in February or early March; winter Jessamine in early February, sometimes January; Daffodils in mid-March; Lily-of-the-Valley and Cottage Tulip early in April; German Iris in mid-April. Roses and Sweet William appear in early May; Delphinium in late May; Hollyhocks in early June; Phlox, July 1. And thus before midsummer's heat many of the best hardy perennials have come and gone. While summer bloom in the highlands is not necessarily destroyed by hot weather, unless unusual drought occurs, yet the autumn garden is apt to be a more refreshing sight with its fresh crop of Roses, the late Chrysanthemum, Cosmos, and indefatigable Zinnia. Of course to the south, and where altitude is lacking, the somewhat higher temperature will more or less alter these garden dates. 


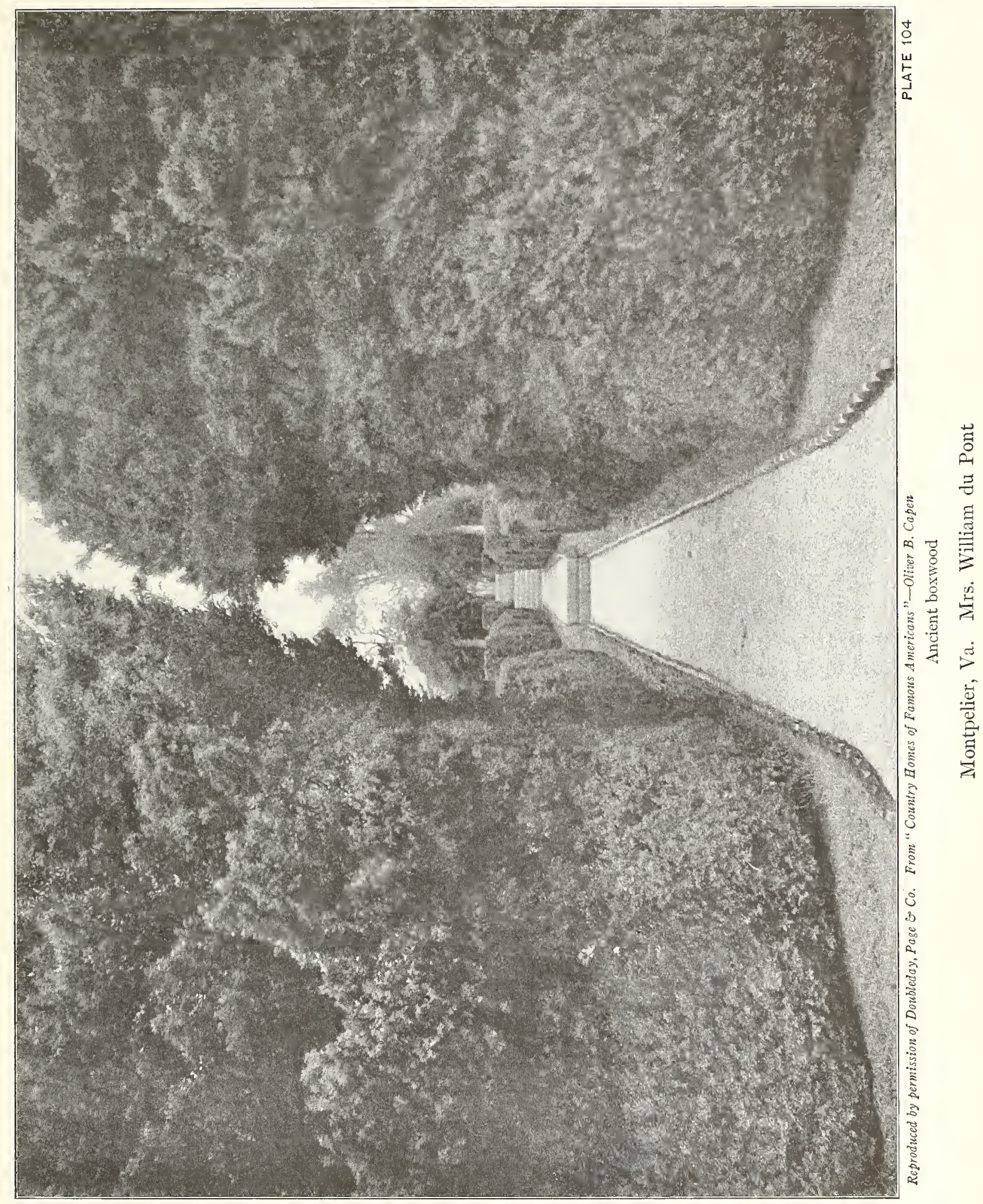





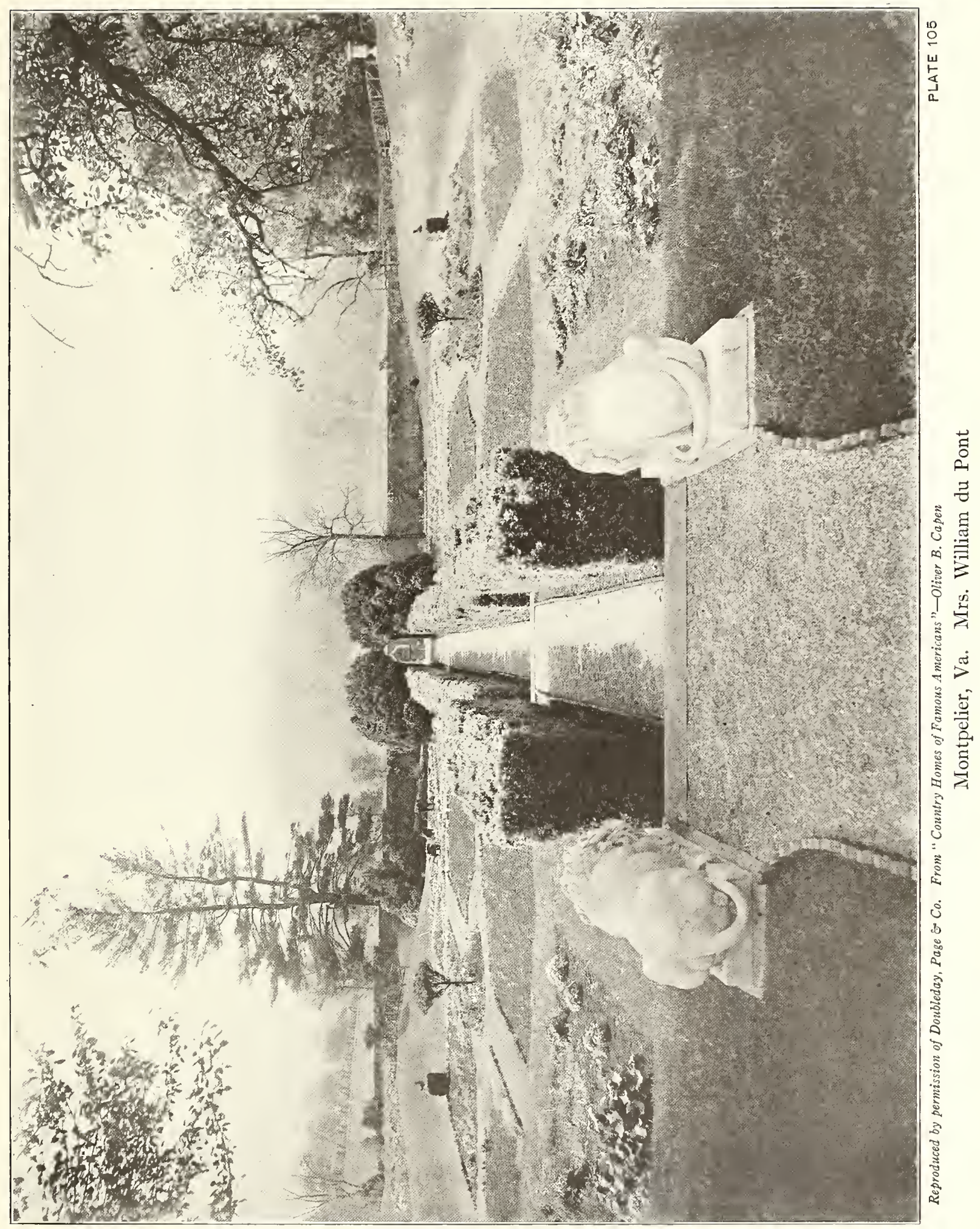





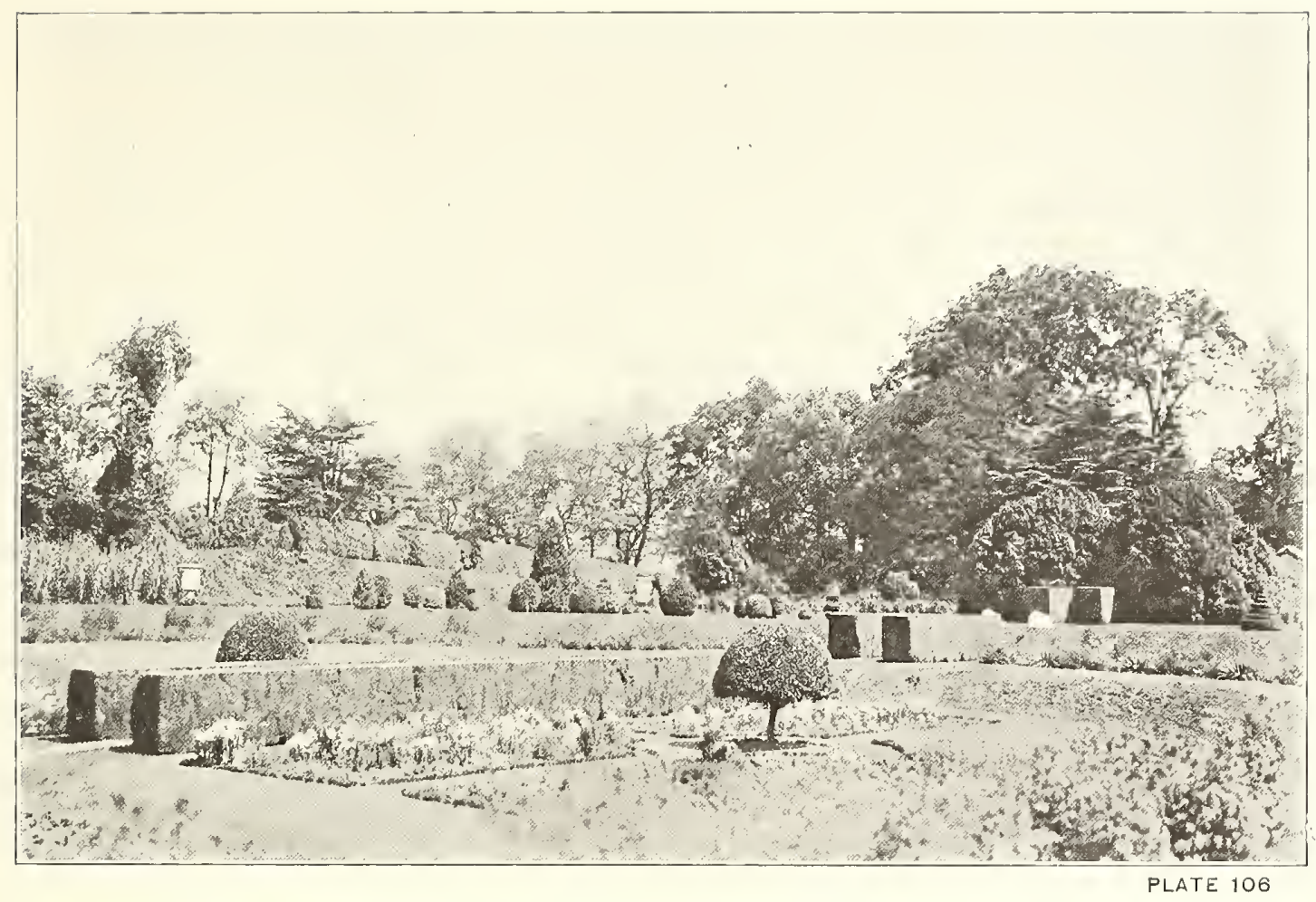

Montpelier, Va. Mrs. William du Pont

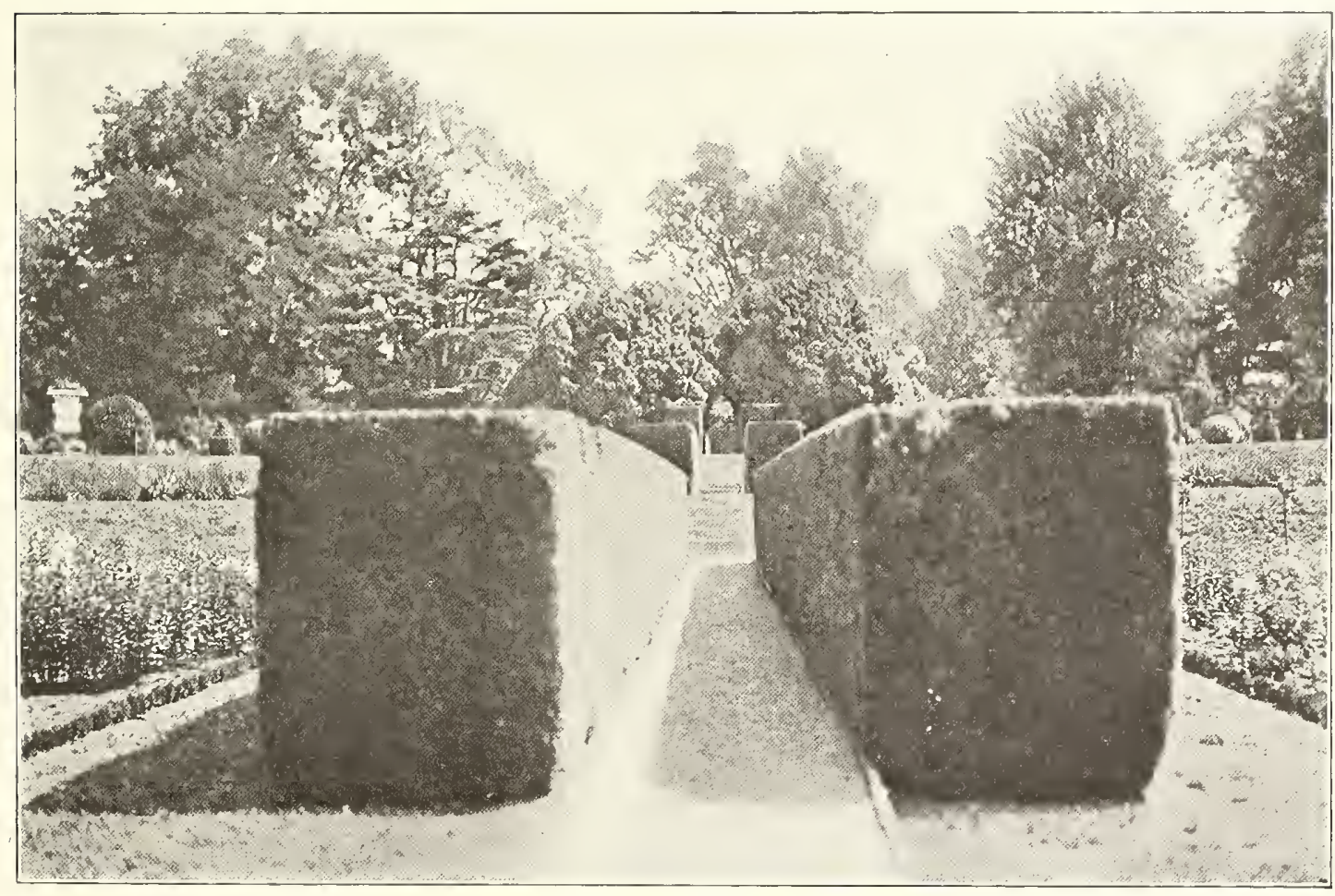

Montpelier, Va. Mrs. William du Pont

PLATE 107 



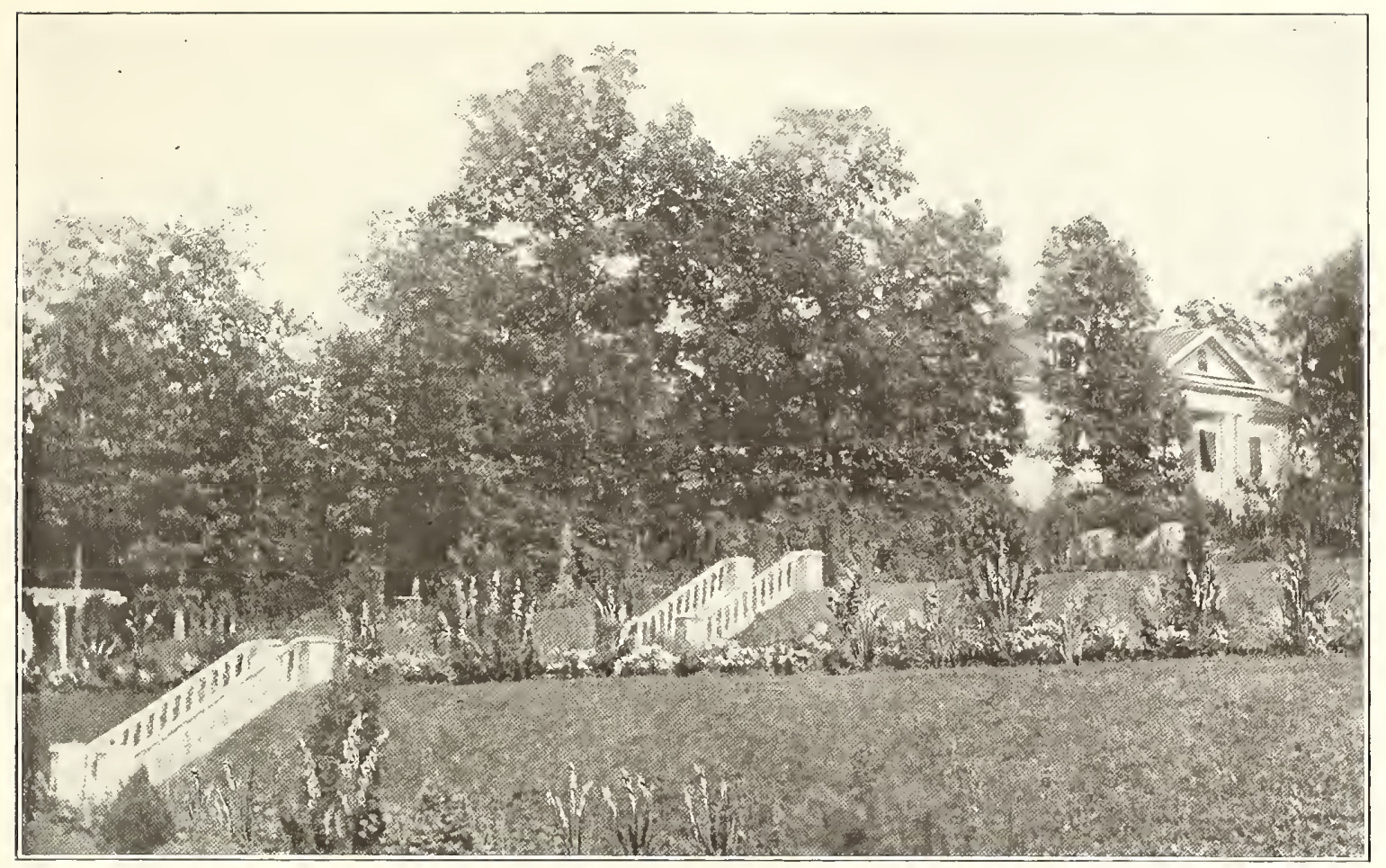

"Rose Hill"

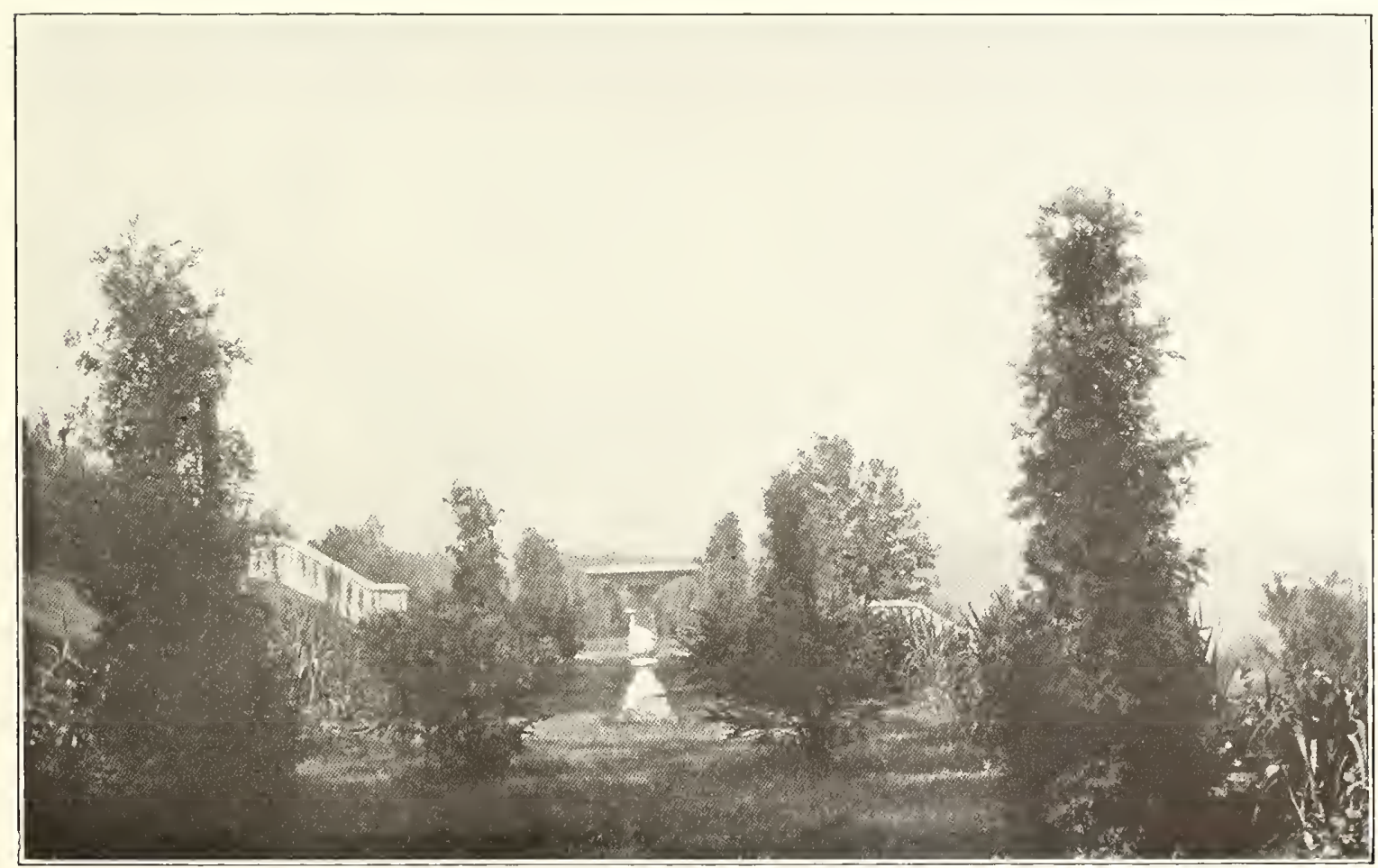

PLATE 109

“Rose Hill," Greenwood, Va. Mrs. W. R. Massie 


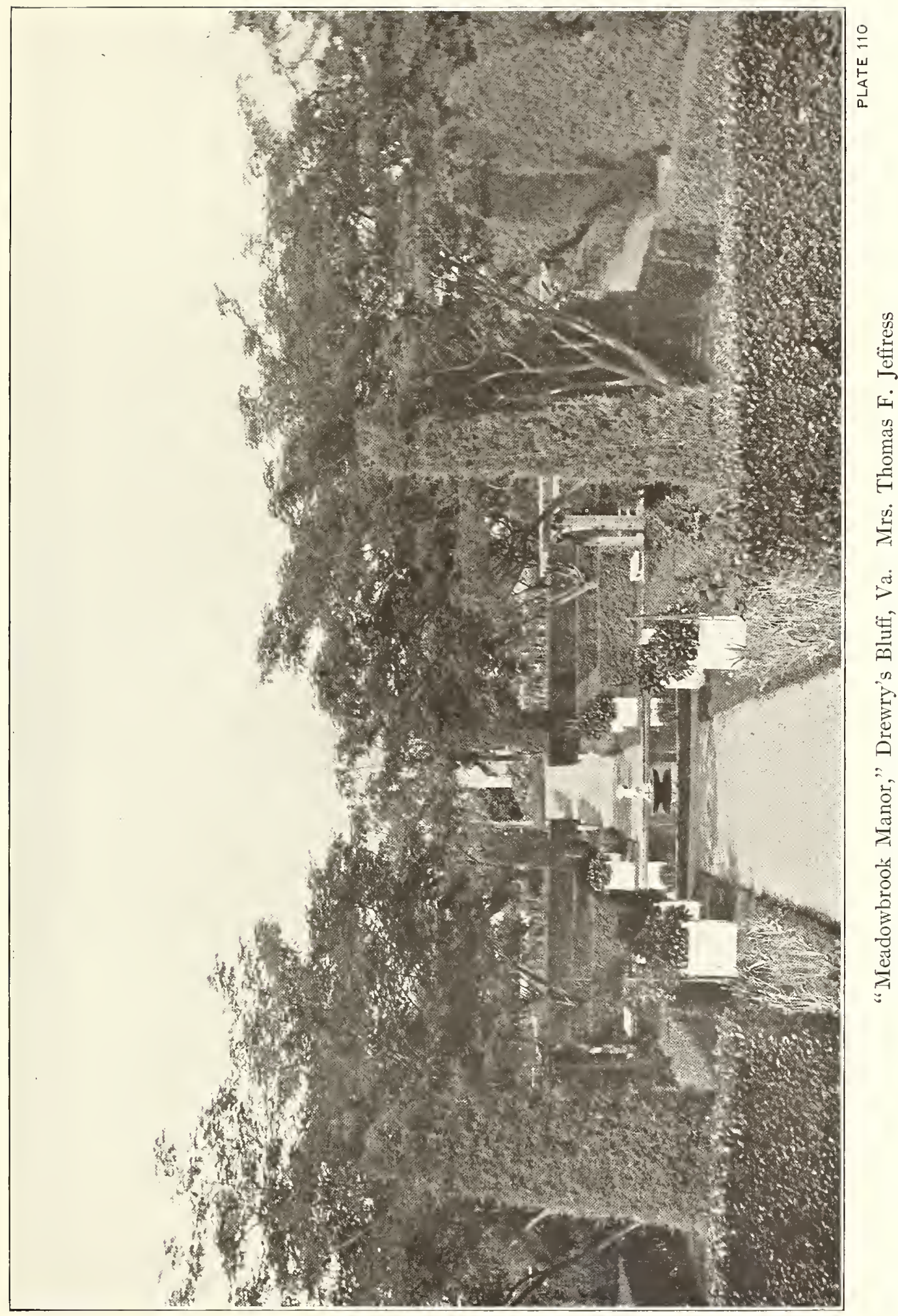





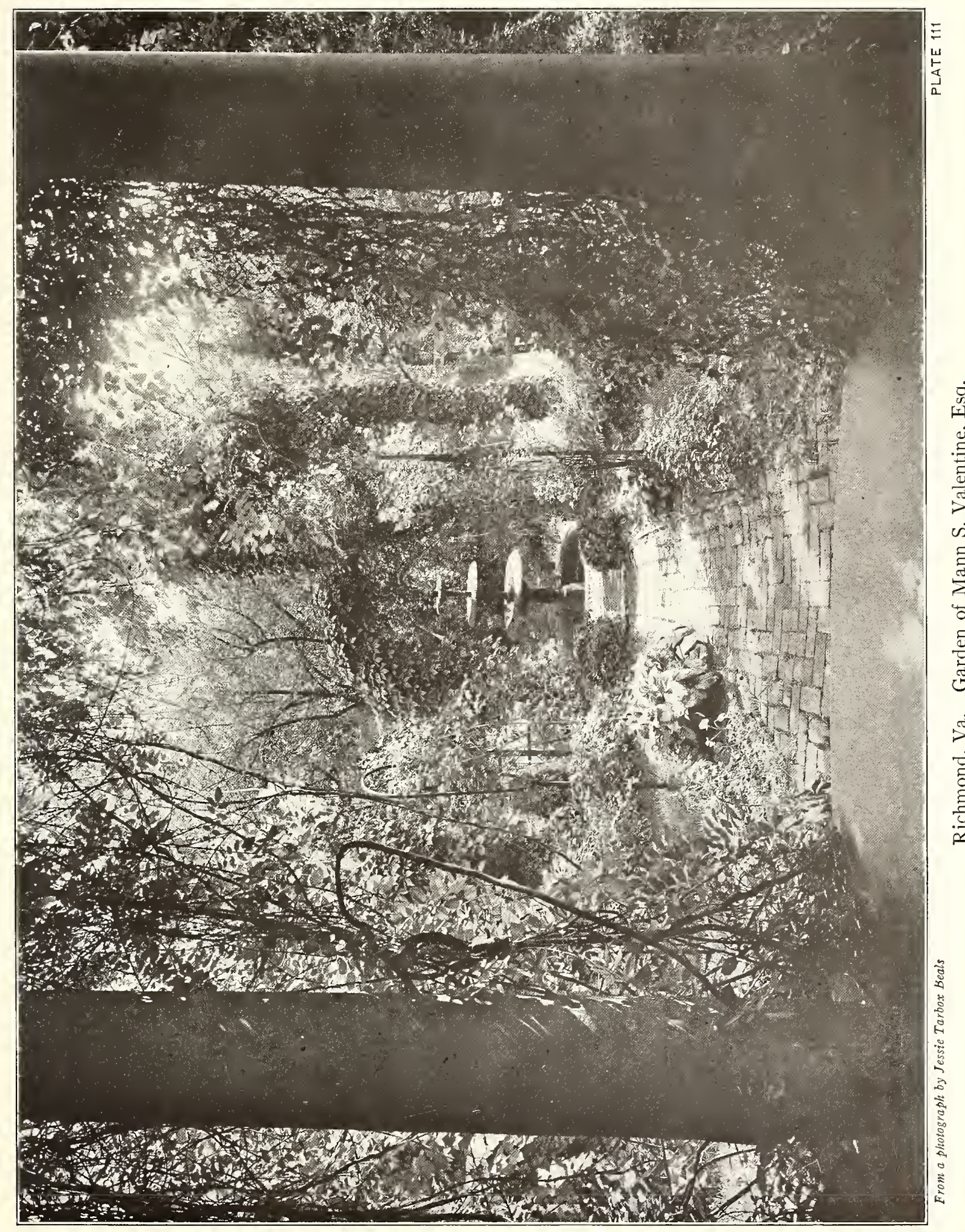




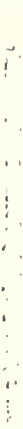




\section{SOUTH CAROLINA}

There are few new gardens in South Carolina, but an untold number of old ones deserving to be revived. Around Charleston, especially, old-time mansions, quaint walls, and gateways abound that are an inspiration to lovers of graceful antiquities. To restore an abandoned garden must be indeed a joy to one with enough imagination to recreate flower places fitted to the surroundings.

The illustrations in this chapter give some idea of the richness of the early gardens laid out by the wealthy owners of many generations past. Magnolia-on-the-Ashley, considered by some as one of the world's most beautiful sights, especially in springtime, is the most famous place in the State. It is owned by Colonel Drayton Hastie, who inherited it from his grandfather, the Reverend Mr. Drayton, an Episcopalian minister, in whose family it had remained since the latter part of the seventeenth century. In the days of the Reverend Mr. Drayton it was discovered that the garden had been laid out over land containing extremely valuable phosphate deposits, but neither he nor his descendants would have the place disturbed for the sake of an increased fortune, and the garden continues as 


\section{BEAUTIFUL GARDENS IN AMERICA}

it was, the delight in early spring of visitors from all over the world. To quote one who resides near by: "The garden first came into notice about a hundred years ago. In spite of all the cultivation, it still suggests the heart of the forest, with the old Oak and gray moss and wild flowers mingling with Cherokee Roses, Jessamine, etc. These Magnolia gardens are not only wonderfully beautiful, but, I believe, quite unique. The great show is not Magnolias, or even the Camellias, although they are lovely — but the Azaleas, which grow in such profusion and variety of shades that one loses all sense of individual plant and flowers and perceives only glowing, gleaming masses of color veiled by festoons of gray moss, giving one a delicious feeling of unreality, almost enchantment. In Owen Wister's 'Lady Baltimore' there is a beautiful description of Magnolia. The coloring on the post-cards is not in the least exaggerated." Live Oaks over two centuries old draped with gray moss suspended from the branches! This wonderful growth is not an uncommon sight in the Southern States.

Columbia, the capital, has the famous Preston garden, and for many generations this beautiful property remained in the families of the Hamptons and Prestons. By a marriage a century ago the Hampton estate came into the possession of the Prestons, and for many years the stately garden with its aged Box and shade trees, its choice shrubs and plants, has been an object of veneration to garden lovers. A descendant writes: "There is no interest of im- 


\section{BEAUTIFUL GARDENS IN AMERICA}

portance attached to the past history of the Preston place, except that it has sheltered quite well known persons in its day, Henry Clay, Thackeray, and Miss Martineau among others, for its owner had acquaintances among prominent people in this country as well as abroad, and delighted in showing them hospitality when they happened in his neighborhood." After the war it shared the fate of almost all the other Southern estates that could no longer be maintained as in former years, and finally became a woman's college, and once more receives the needed care.

In the low coastal country, including Charleston, spring opens in February with Camellias, Daffodils, and bulbs. German Iris appears at Charleston soon after March 15, Phlox in June. Delphinium and Hollyhock and some others do not thrive in this section. The flowers that are carried over for autumn bloom are hardy Chrysanthemum, with Cosmos, Salvia, Marigolds, and Zinnias, and a few others able under care to resist the summer heat. Frost may come by November 15, but in winter thin ice forms only about three times, with the thermometer at twenty-five degrees. White Camellias sometimes begin to blossom at Christmas time. Such is the climate of this level. In the higher regions of the State climatic conditions are somewhat different and the summer heat is not as extreme. 



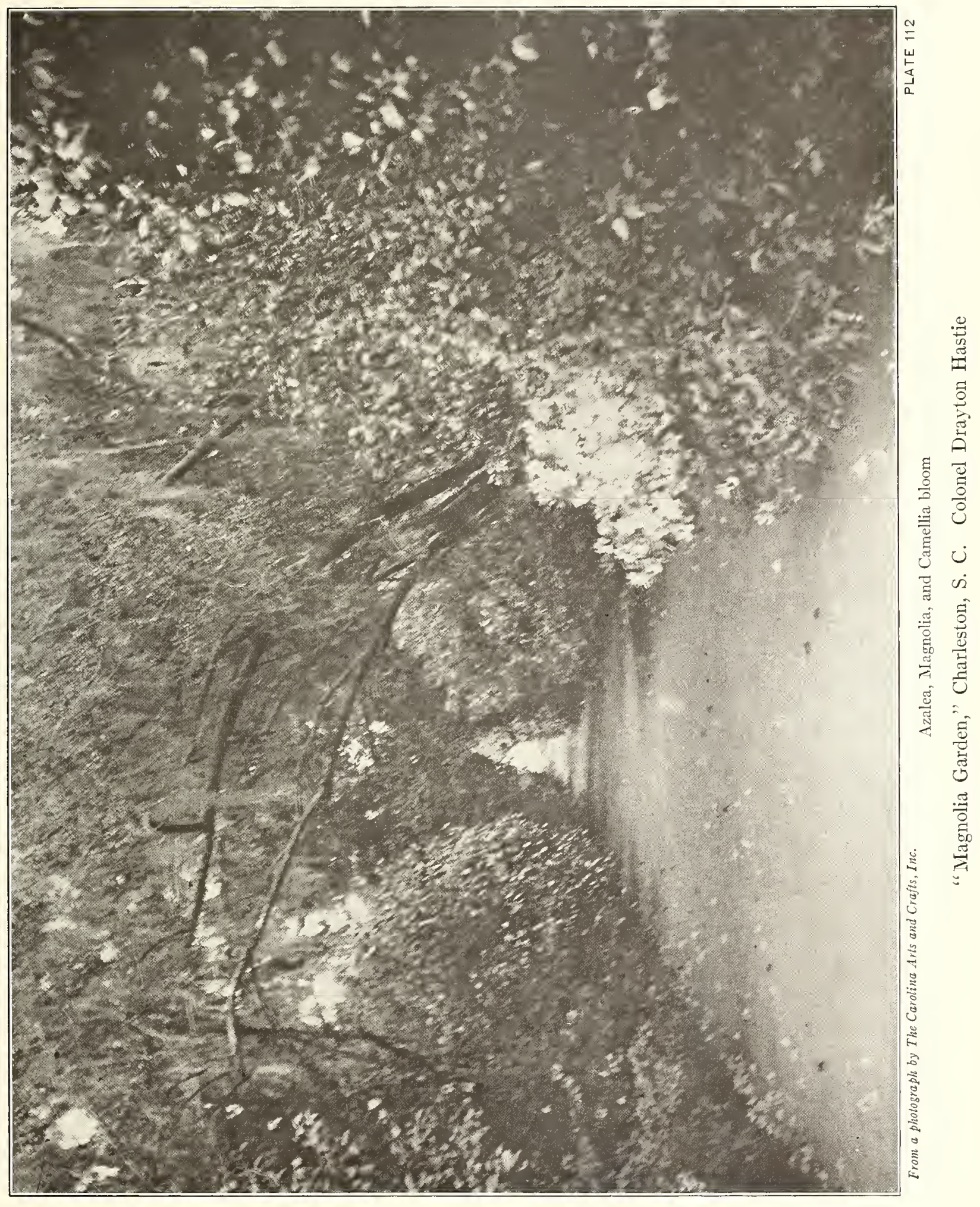





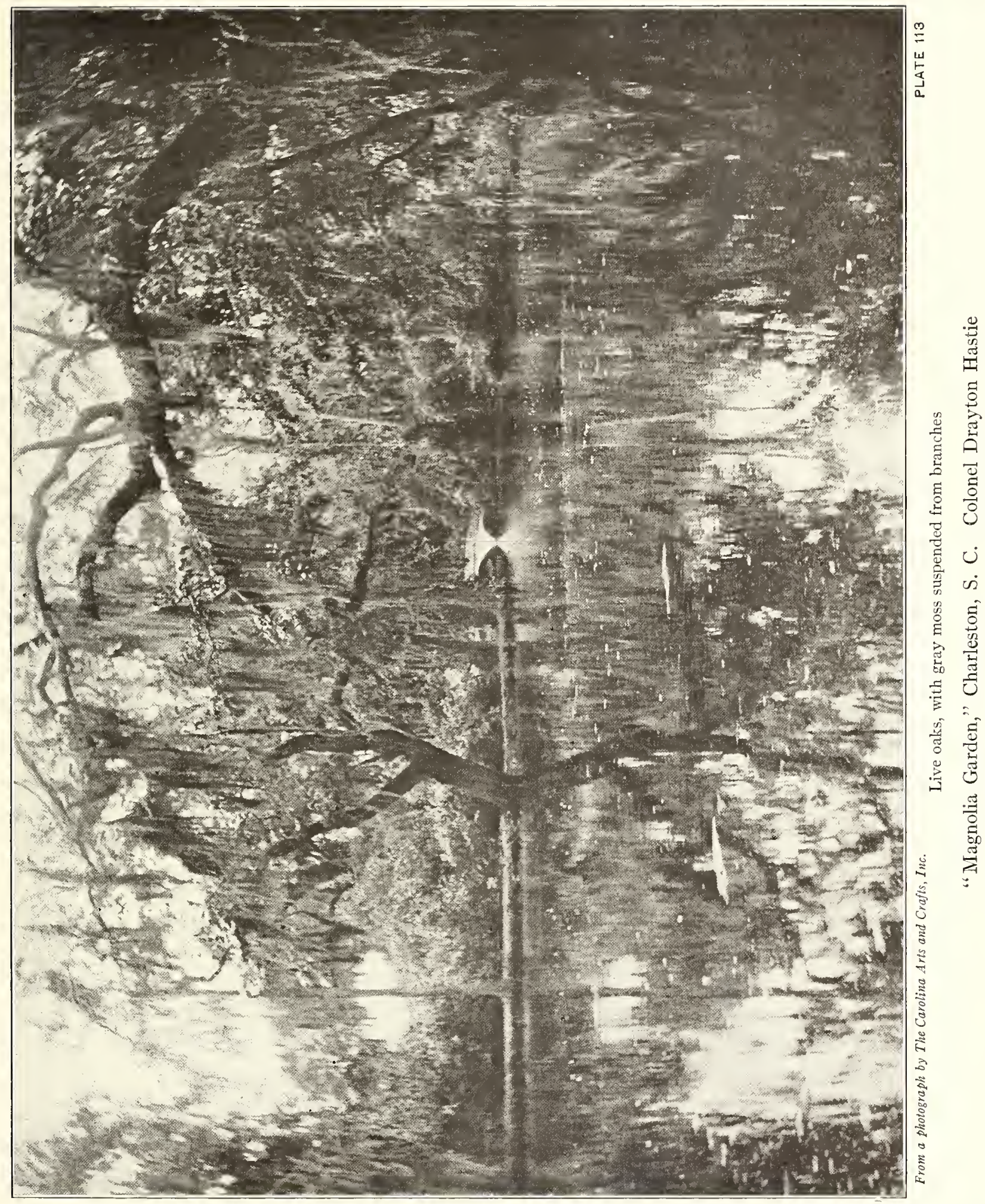





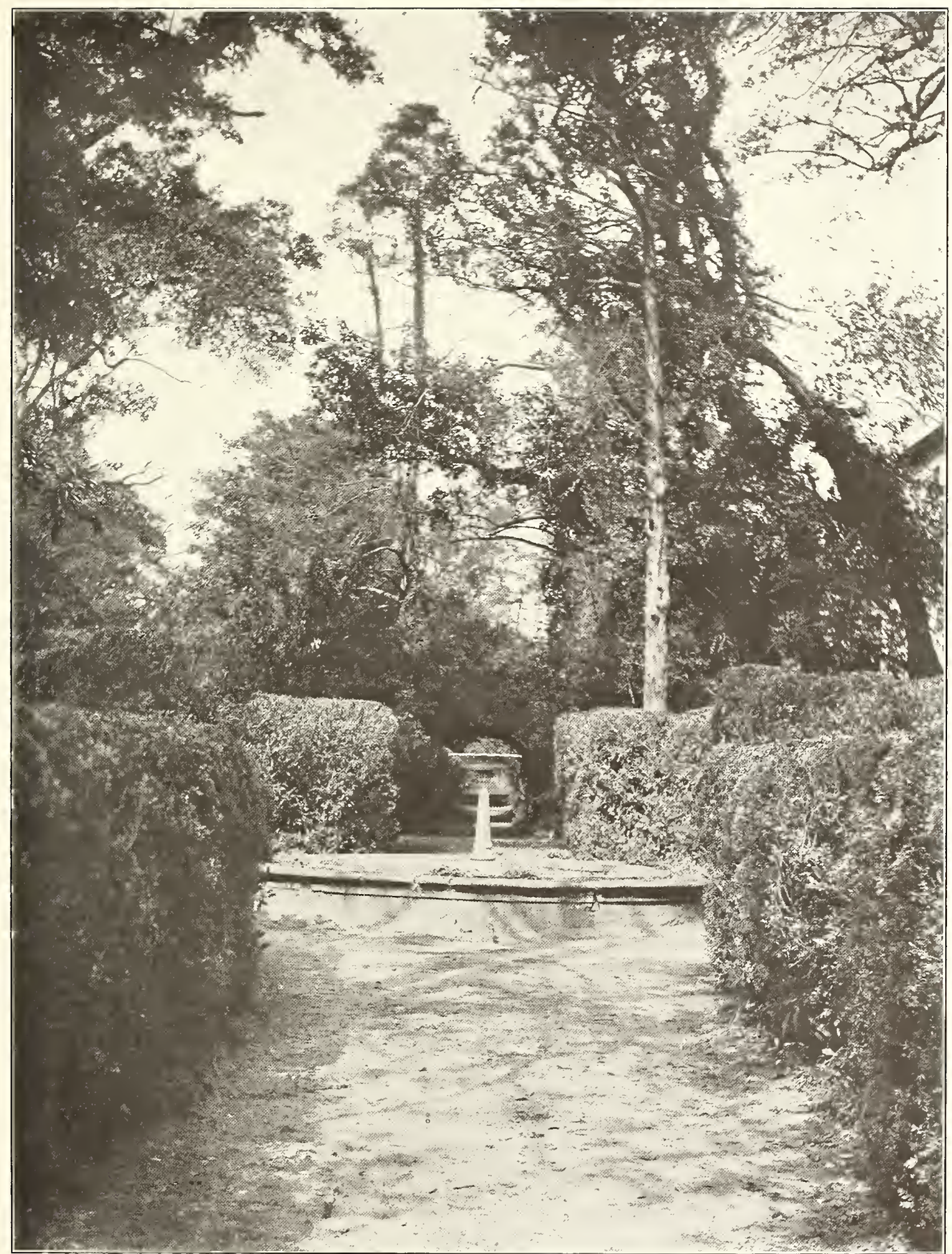

From a photograph by Lyle E Escobar PLATE 114

"Preston Garden," Columbia, S. C. 



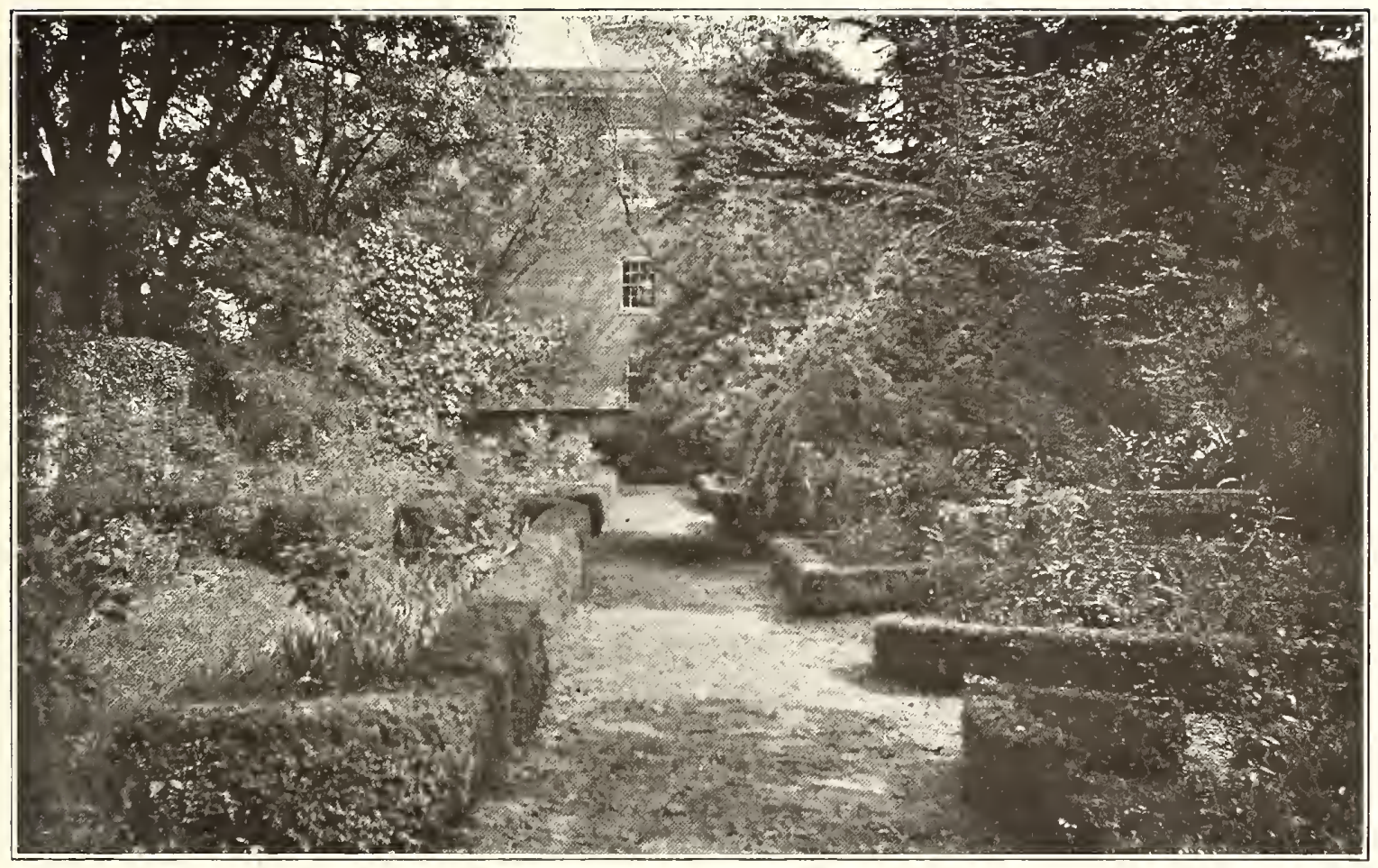

PLATE 115

"Preston Garden"

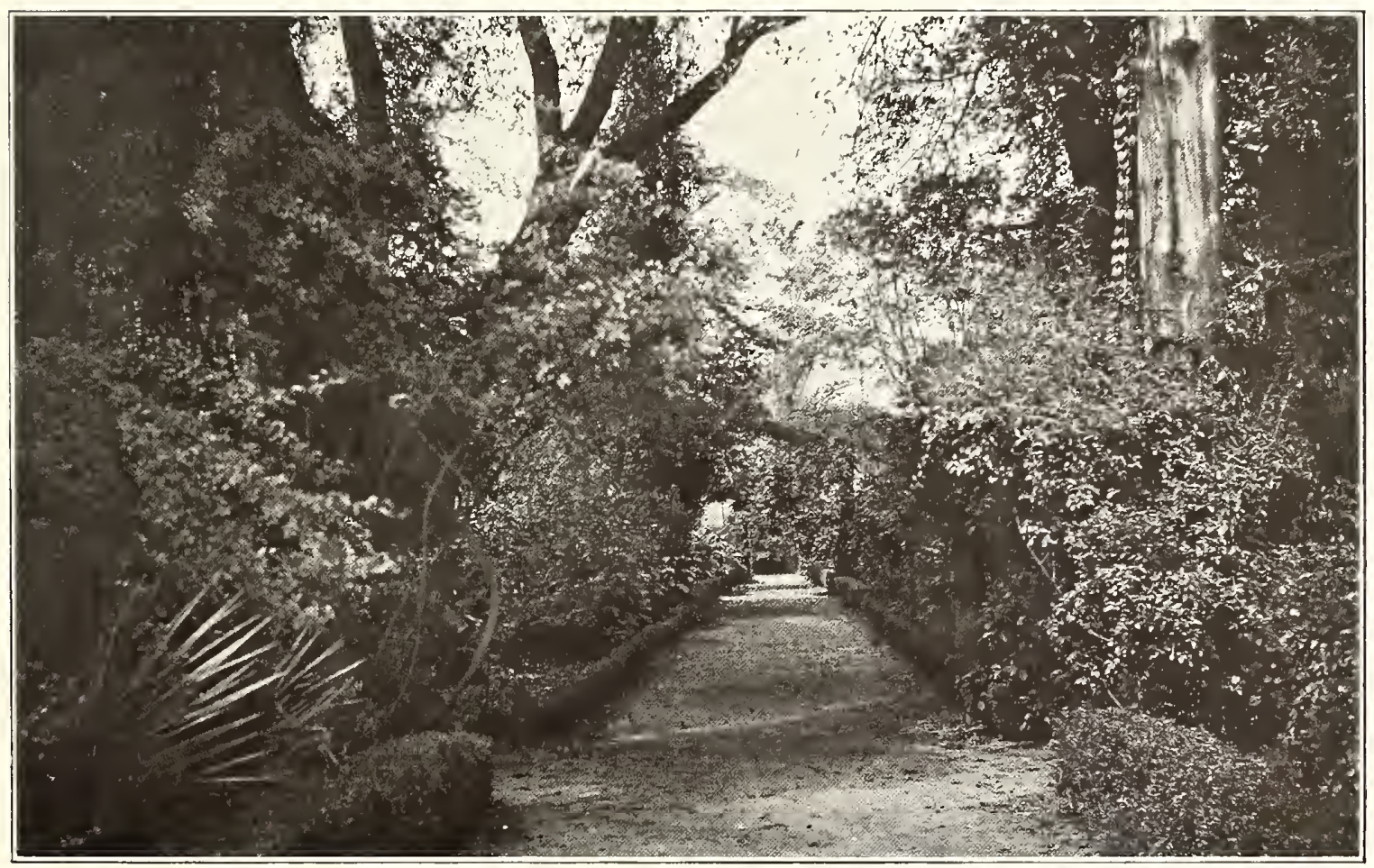

From photographs by Lyle \& Escobar

PI.ATE 116

"Preston Garden," Columbia, S. C. 



\section{$\mathrm{X}$}

\section{GEORGIA AND FLORIDA}

Summer gardens, on account of the climate, are not attempted in the States of the far South; but as popular winter and spring resorts the grounds at these seasons about the villas and hotels are adorned with Palms, Roses, and other plants adapted to the climate. Charming spring gardens in formal designs are found in Georgia, where, because of its somewhat cooler climate and better soil, there are a greater number of private estates than in Florida. The former State doubtless suffered more than any other in the Civil War and, consequently, enforced neglect of the old gardens brought ruin to most of them. At present some of the finest places in Georgia are delightfully located outside of the larger towns, and many gardens, some new and others renewed after a half-century of oblivion, adorn the home grounds of those who are so fortunate as to reside here at the most favored seasons.

The illustrations of the gardens at Green Court are fair samples of the extensive planting in many places. Spring bulbs begin to open in this lovely spot by the middle of February, Camellias often come in January, German Iris appears the middle of March, Delphiniums in April. 


\section{BEAUTIFUL GARDENS IN AMERICA}

In Georgia the summer heat finishes most of the bloom, and few would venture with autumn flowers. "The Roses, however, when well tended, rest during summer to bloom gloriously again in October and until the time of light frost, which comes in December." The interior of the larger garden at Green Court, surrounded with its splendid outer court, is more spacious than the glimpse through the gateway would suggest. The charm of this enclosure, like Southern hospitality, is a combination of bountifulness and grateful simplicity. Green Court deserves to stand as a representative garden of its State.

With an almost similar climate the adjoining State of Alabama has its gardens also, but, unfortunately, photographs are not now available.

Palms of every description are the characteristic plants of Florida. The State is generally flat and open, but in the north the country is more wooded, often wild and swampy, with picturesque winding little rivers meandering to the coasts.

The conditions in the populous districts of Louisiana and Texas are so similar to Florida, where gardens are concerned, that it is unnecessary to use further space in describing plant life in these States. 


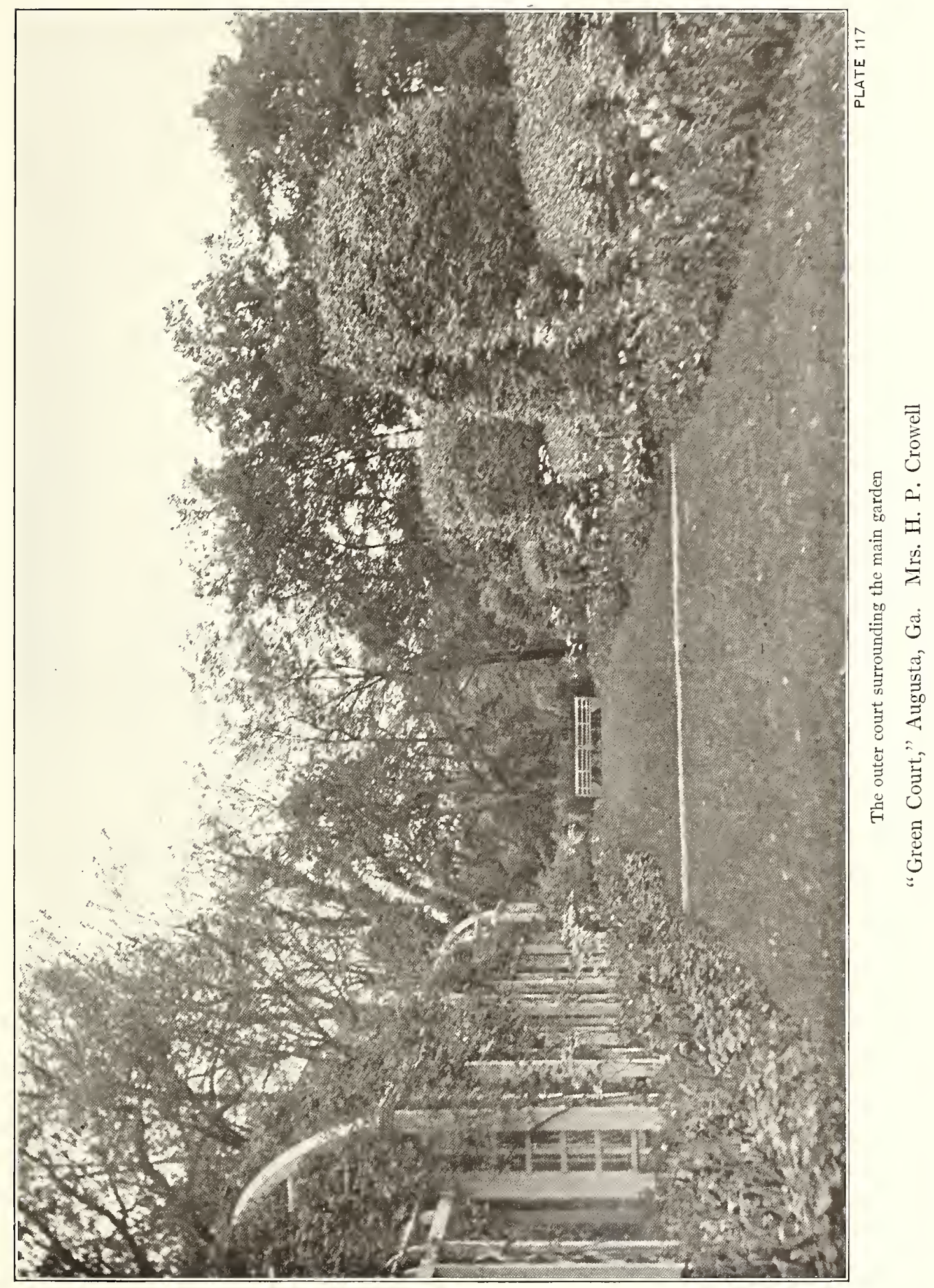





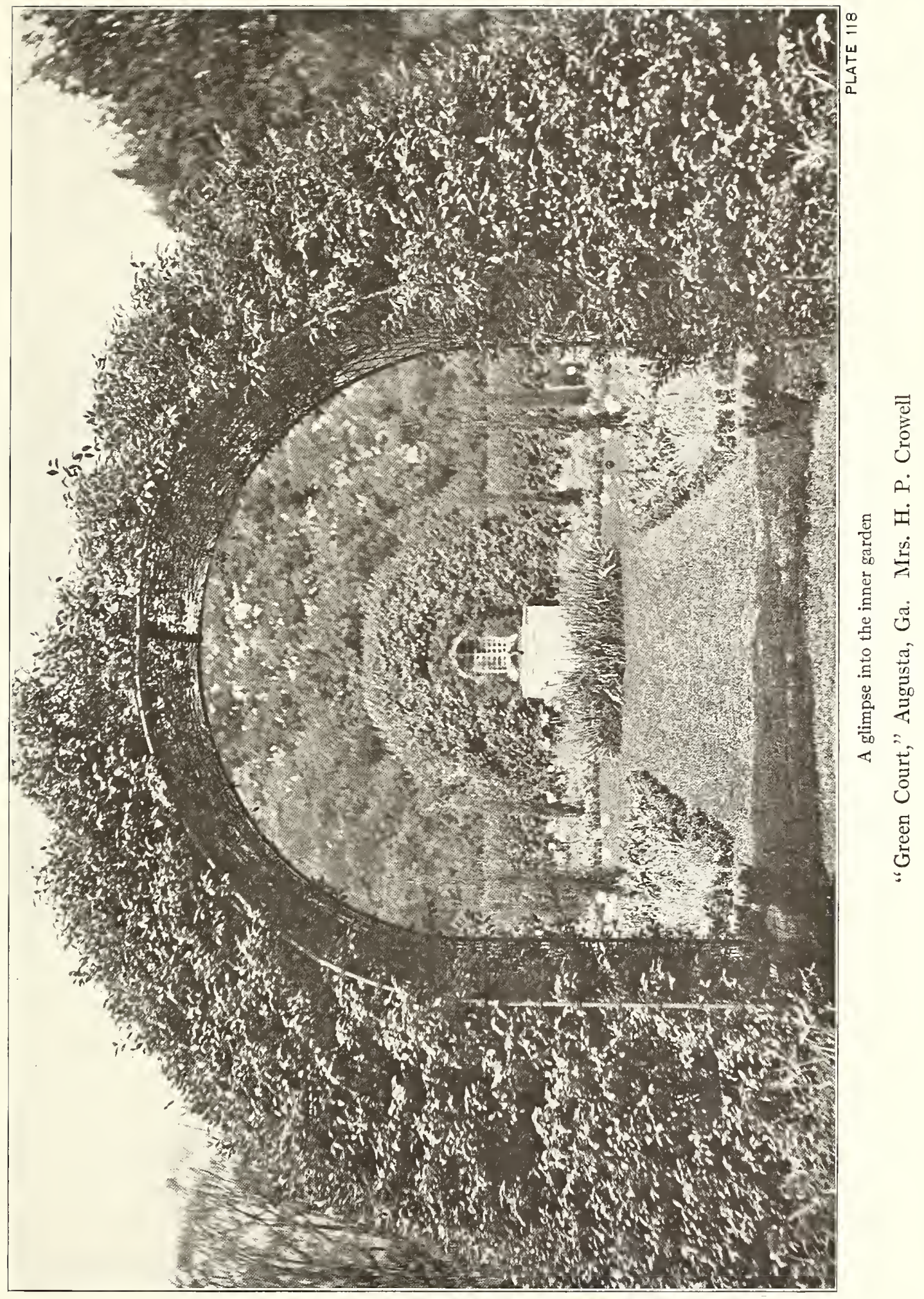




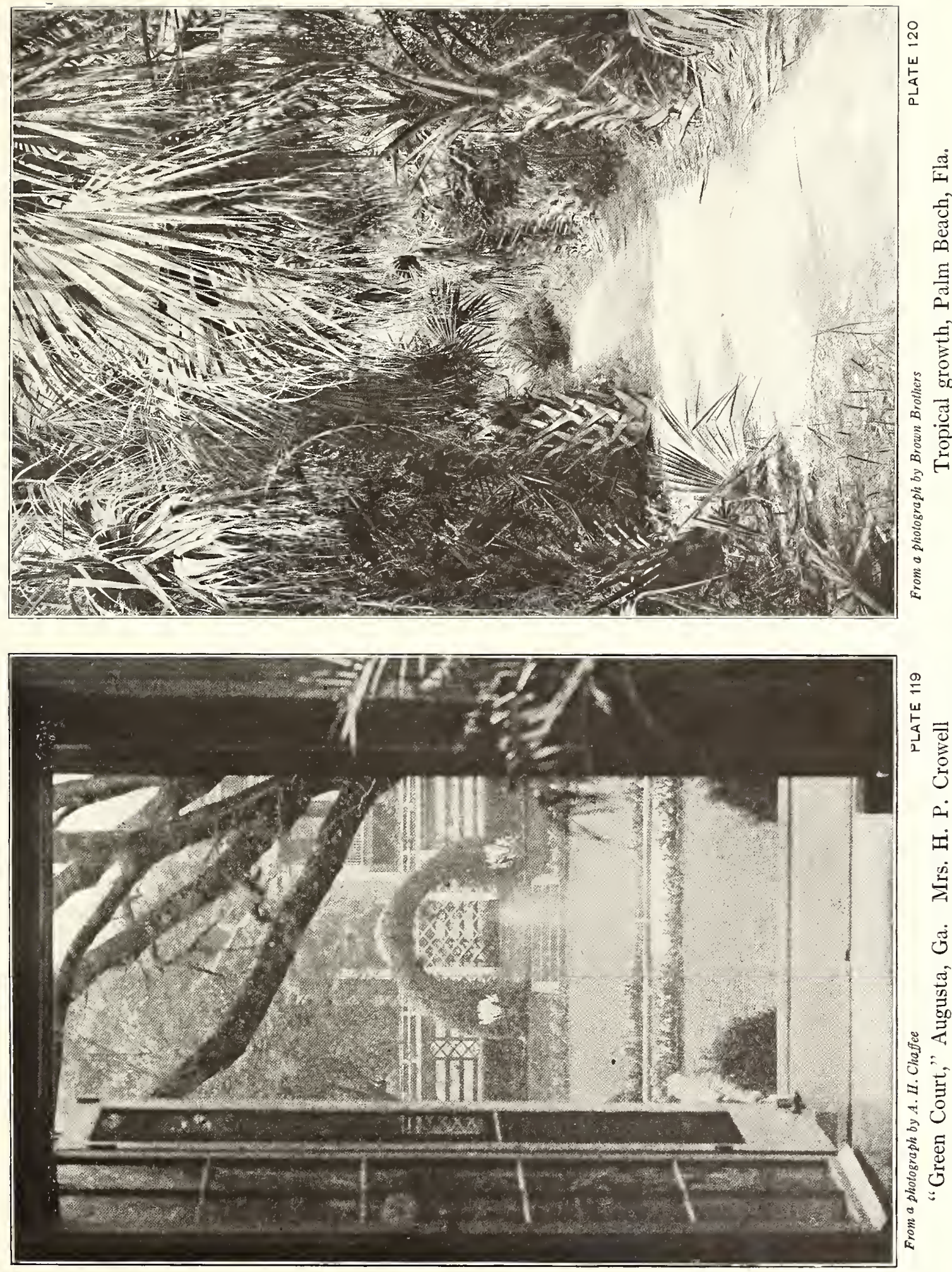



\section{XI}

\section{TENNESSEE AND MISSOURI}

From Tennessee the following description of its garden life is agreeably presented: "Here in the South interest in this subject is always increasing. We have many old and beautiful gardens full of sentiment. The mistress of the place is always head gardener, and in no instance does she relinquish her position to another. I am filled with enthusiasm in garden matters, and would preach the gospel of the garden to all women."

Daffodils appear in February, Lilies-of-the-Valley and Cottage Tulips in mid-April, German Iris soon after. The droughts of midsummer may injure but not necessarily destroy the flowers. The winter thermometer occasionally falls to twenty degrees above zero in the cooler districts, and such plants as Snapdragon and Campanula medium are more safely wintered in a slat-frame. But winter once over the tender annuals can be put out as early as April 25. These conditions apply almost equally to the neighboring States of Kentucky and North Carolina, having as well their records for old-time gardens.

The planting at Rostrevor speaks delightfully for the many others belonging to this section of the South. This 


\section{BEAUTIFUL GARDENS IN AMERICA}

garden, filled with Lilies and other blossoms, shows that the Southern woman is as truly a flower lover as were they who planted the early gardens in the days before the war.

What more tantalizing to the garden devotee than the glimpse beyond the gates of Longview garden as illustrated in this chapter, and again in a later section? Such views as these, so exceedingly artistic in themselves, suggest a still more lovely interior, at present withheld because adequate photographs are lacking.

In Missouri, as in Kansas and elsewhere in the Middle West, there is great variableness of climate from year to year, and never is it an ideal district for summer flower gardens. While much attention is being given to shrubbery and perennial beds bordering the lawn, there are few actual gardens, formal or otherwise. The discouragements of a trying summer climate limit the bloom in most of the places to the flowers of spring and June. Early flowering plants and bulbs, German Iris, Foxglove, Canterbury Bells, Columbine, Peonies, Lilium candidum, Roses, and Hollyhocks, give considerable satisfaction. But many other perennials are not at all permanent. To quote an experienced amateur gardener: "The climate of Kansas City, Missouri, is subject to every eccentricity, and at times is very trying. One of my experiences was a four or five inch snow-storm on the $3 \mathrm{~d}$ of May after a month of warm spring weather, when German Iris and many other things were in full bloom, and Peonies in bud. Everything was mashed down and then it froze. 


\section{BEAUTIFUL GARDENS IN AMERICA}

Often when Peonies have been in bloom torrential rains have nearly ruined them. The greatest trouble with the summer garden is the extreme heat and dryness of the air: The earth can be kept moist around the plants, but many things wither in the dry air. With the greatest care a garden of annuals might be kept looking fairly well through July and August, but I am glad to get away from mine early in July."

The climate of these adjoining Middle States is practically the same throughout, with possibly even more sunshine than in the eastern States. "In May and June there are frequent heavy showers, but rarely all-day rains. In the later summer and autumn cloudy days are exceptional. The eastern side of Missouri is said to be slightly cooler than the western part; Kansas City averages a somewhat higher summer temperature than Washington, D. C., which is in the same latitude. Spring bulbs and many spring perennials appear three weeks earlier than near New York City." The gardens usually look spent by September, but in the cooler sections, with an extra amount of summer care, there may be still seen flowers sufficient to adorn a garden during some weeks of autumn.

The garden at Hazelwood, near St. Louis, is laid out with curving grass paths and broad beds. The bright display begins with Daffodils, and the beds retain rich bloom into the middle of June. In September, after good care, Marigolds, Zinnias, Snapdragon, Cosmos, hardy Asters, Chrysanthemum, and Helenium are the autumn 


\section{BEAUTIFUL GARDENS IN AMERICA}

decorations. Frost usually finishes everything about October 15 . The winter temperature is often ten degrees below, and the tender plants, like Foxglove and Pansies, are more safely wintered under slat-frames covered with straw, and Larkspurs should have a light covering of leaves. Surely the gardens that are faithfully tended through such changes and chances of climate as found in this section bespeak the highest degree of devoted patience. 


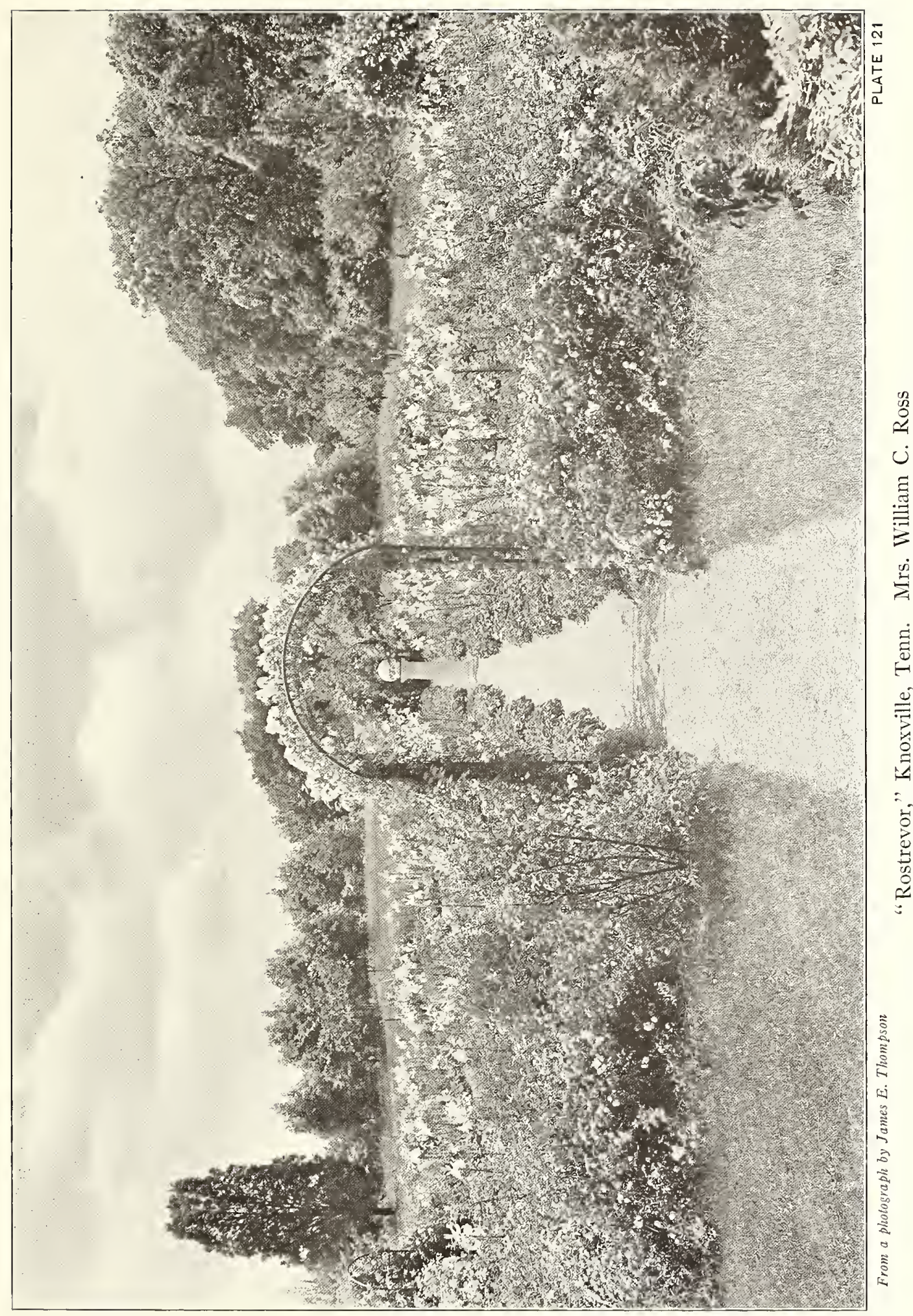





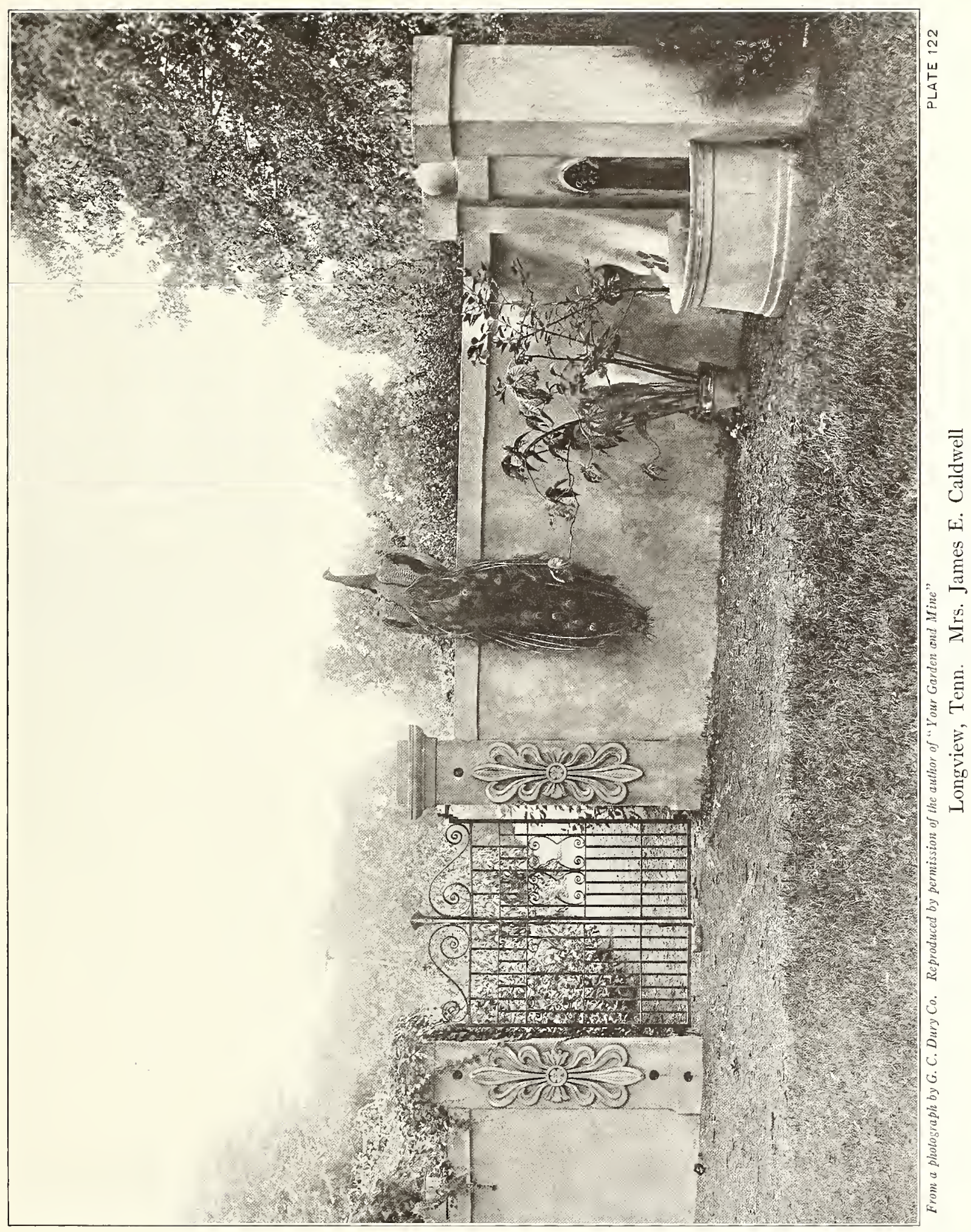




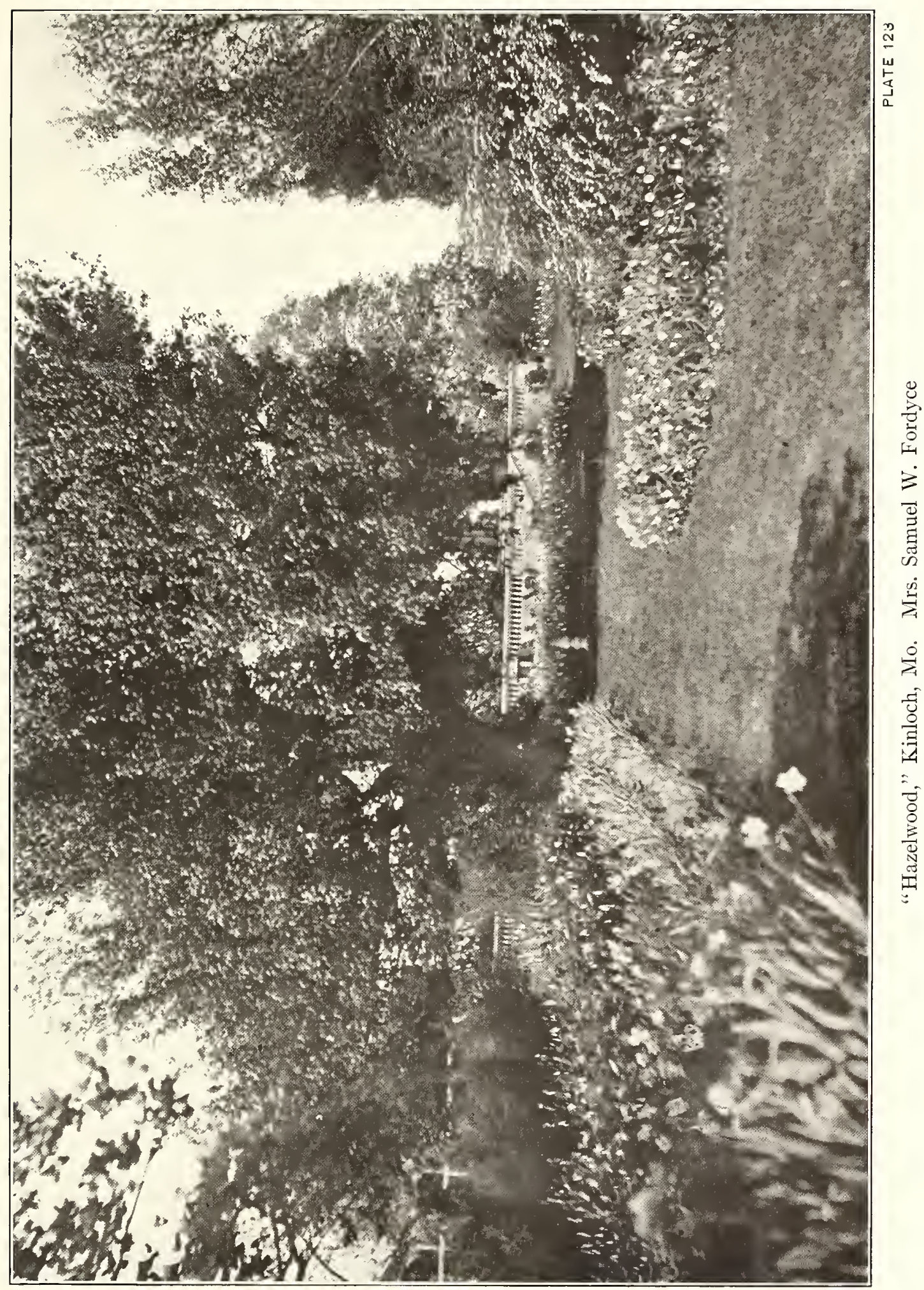





\section{XII}

\section{ILLINOIS AND INDIANA}

Illinois, with its claim to countless fine estates, includes a plentiful share of gardens, and more especially in the lake region, where luxuriant growths of trees tell of congenial soil and climate. As a background the great lake stretches like a sea beyond many of the beautiful flower-borders, which bloom almost as richly as those near the distant ocean.

Unfortunately some of the finest plantings are not illustrated in this book, which is limited to gardens of a formal design, and the type characteristic of Illinois is mostly informal, as so frequently seen in America, - an arrangement which does not lend itself satisfactorily to photography. In such a plan the flowers are usually massed in long, broad beds bordering the lawn, the front lines are laid in irregular curves, with trees and shrubs for the background. Groups of shrubs with other beds are sometimes used to break a wide stretch of lawn, and make a rambling and delightful sort of garden scheme. But in photography detail is lost when the camera is at sufficient distance to include more than a small section of such a design. For this reason pictures can never do full 


\section{BEAUTIFUL GARDENS IN AMERICA}

justice to the flower planting on such notable places as those of Albert N. Day, Esq., Lake Forest; Wm. C. Egan, Esq., Egandale, Highland Park; George Higginson, Esq., Meadow Farm; and W. G. Hibbard, Esq., both at Winnetka, and many others.

The spring display of late Tulips at Highland Park and Lake Forest is especially remarkable. Masses of Darwins and Cottage varieties in perfect color blending are planted everywhere, in the woods, in shrubbery, and in borders.

The illustration of the formal garden at Lake Forest, owned by Harold McCormick, Esq., gives a vivid idea of the form and finish of this charming place, which must always stand among the best of middle West gardens, well favored in the beauty of its surrounding trees and generously planted with perennials and shrubs. It has the charm of individuality rather uncommon to large gardens, and stands for that welcome type which seeks to be itself.

Hardin Hall garden, with the great lake as a background, has recently joined the ranks of beautiful American gardens. Every new garden is as a jewel added to the crown of its State, and this little gem in planting is noted throughout the North Shore. Stepping-stones in the grass lead to another green enclosure, designed on a less formal plan, - the whole scheme being most artistically conceived.

The climate near the lake is slightly cooler than in 266 


\section{BEAUTIFUL GARDENS IN AMERICA}

other localities, spring opening from one to two weeks later than inland. The difference in time of spring bloom on this shore and near New York City is only about a week. The climate on the lake front is especially variable. The country is a flat upland broken with wooded ravines.

Out in central Illinois, in Piatt County, there are fifteen thousand acres belonging to a famous estate beyond Monticello. The Farms contains delightful gardens on an extensive scale, quite English in design, and as far as possible in keeping with the Georgian architecture of the house. Juniper Hibernica is freely used over the main garden, enriching with its deep evergreen tones the broad expanse of flower-bordered beds. The walls are covered with Chinese Wistarias, Japanese Honeysuckle, trained peach trees, nectarines, pears, and plums.

Monticello is in the latitude of Philadelphia; the blooming dates almost correspond, but frost destroys a trifle earlier. The highest summer thermometer rarely reaches one hundred degrees, sometimes dropping in winter to twenty-seven degrees below. Tender annuals can usually be planted out after May 15. Mulching and watering is necessary to preserve the summer bloomers.

Famous in the annals of southern Indiana is the large estate at Lexington known as Englishton Park, and for six generations the property of the English family.

Problems of insufficient rain, poor soil, and rocky ground have been overcome by most scientific measures, and now a pool filled with Lilies and bordered with water- 


\section{BEAUTIFUL GARDENS IN AMERICA}

loving plants is a feature of a wonderful rock garden abundantly and tastefully planted with the perennials most suitable for rocks or for moisture. The Rose garden near by and long path leading to the house, bordered with beds of perennials, are further delightful tributes to the devoted labor of one who has spent much time on this, her gladdest task. 


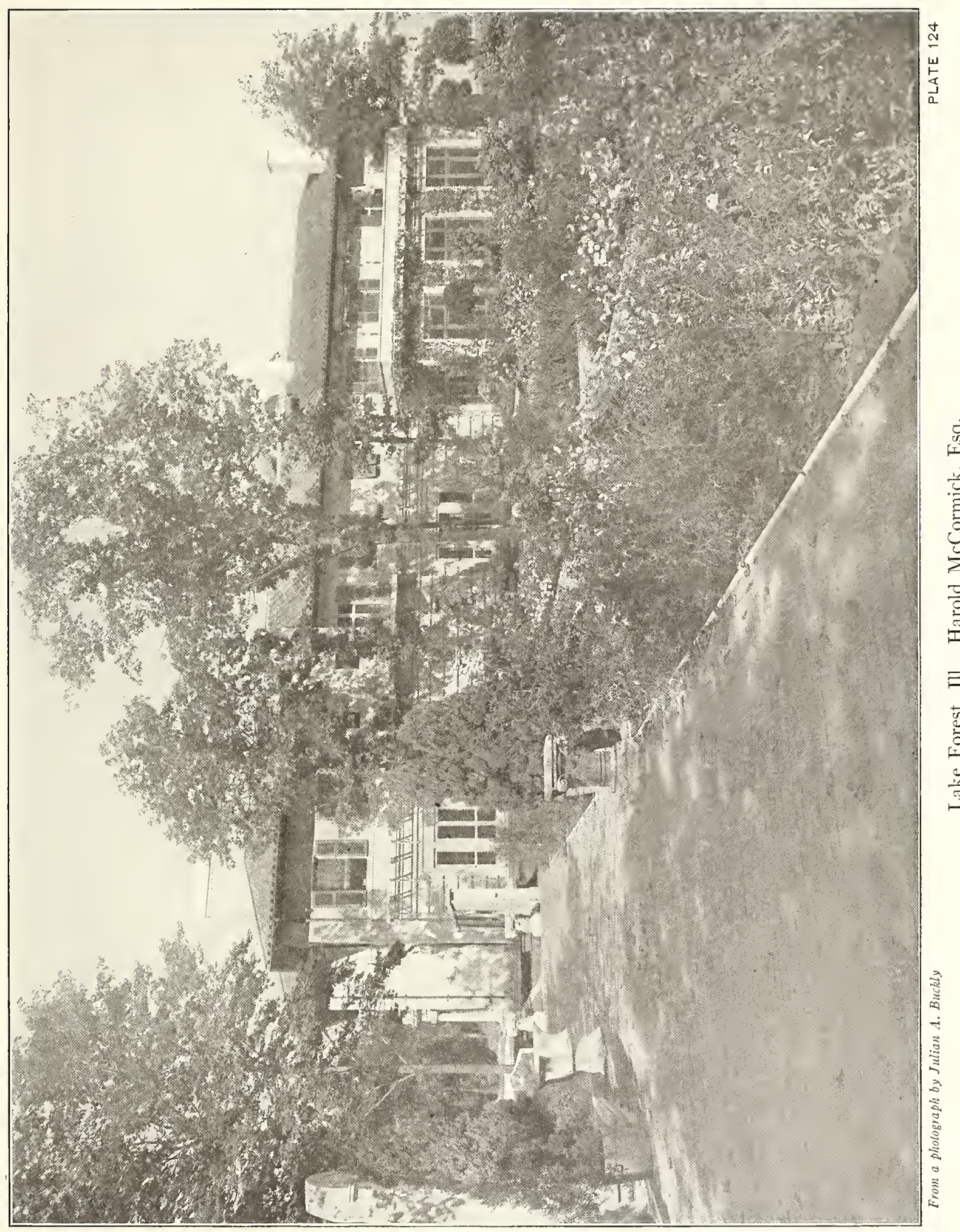





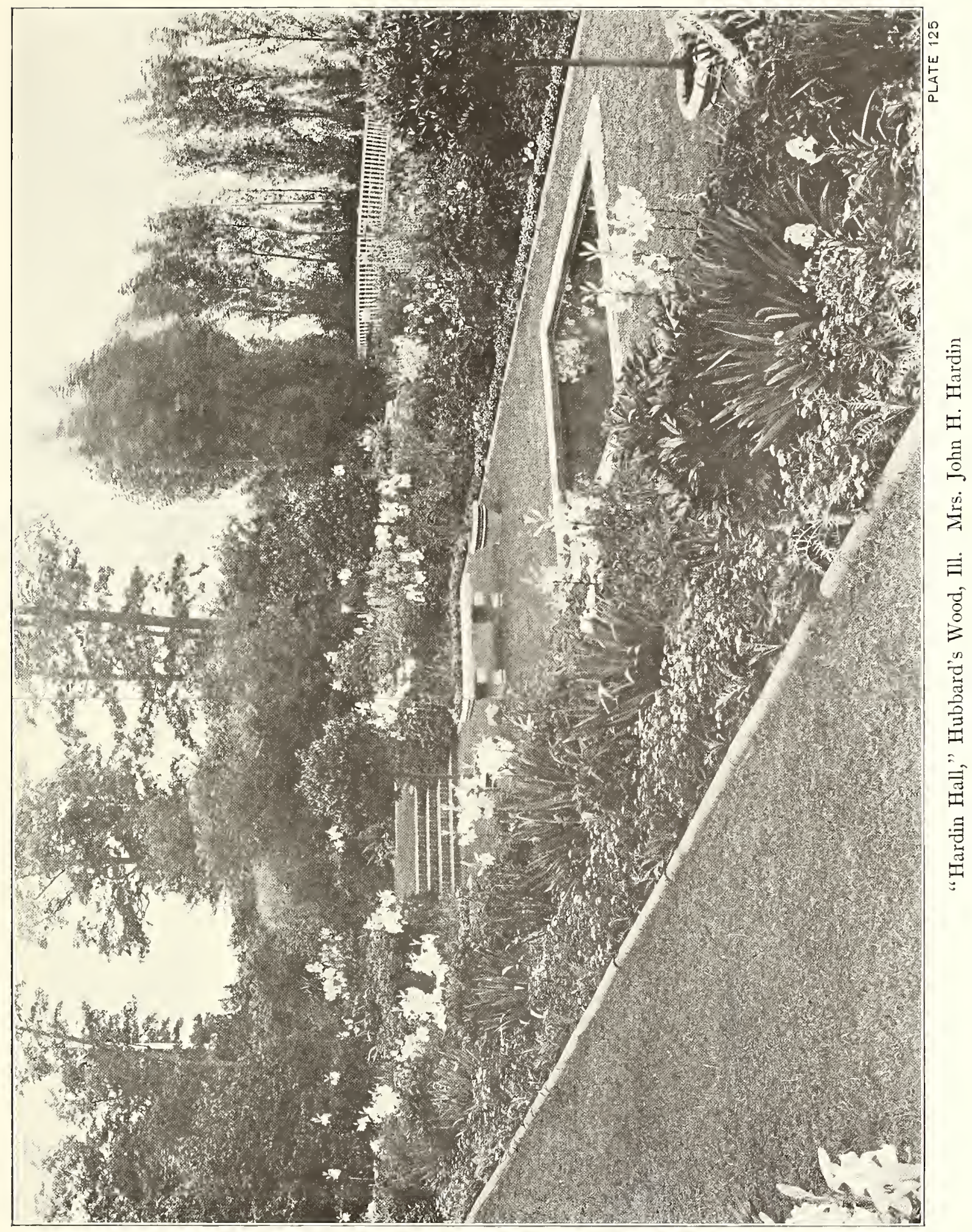





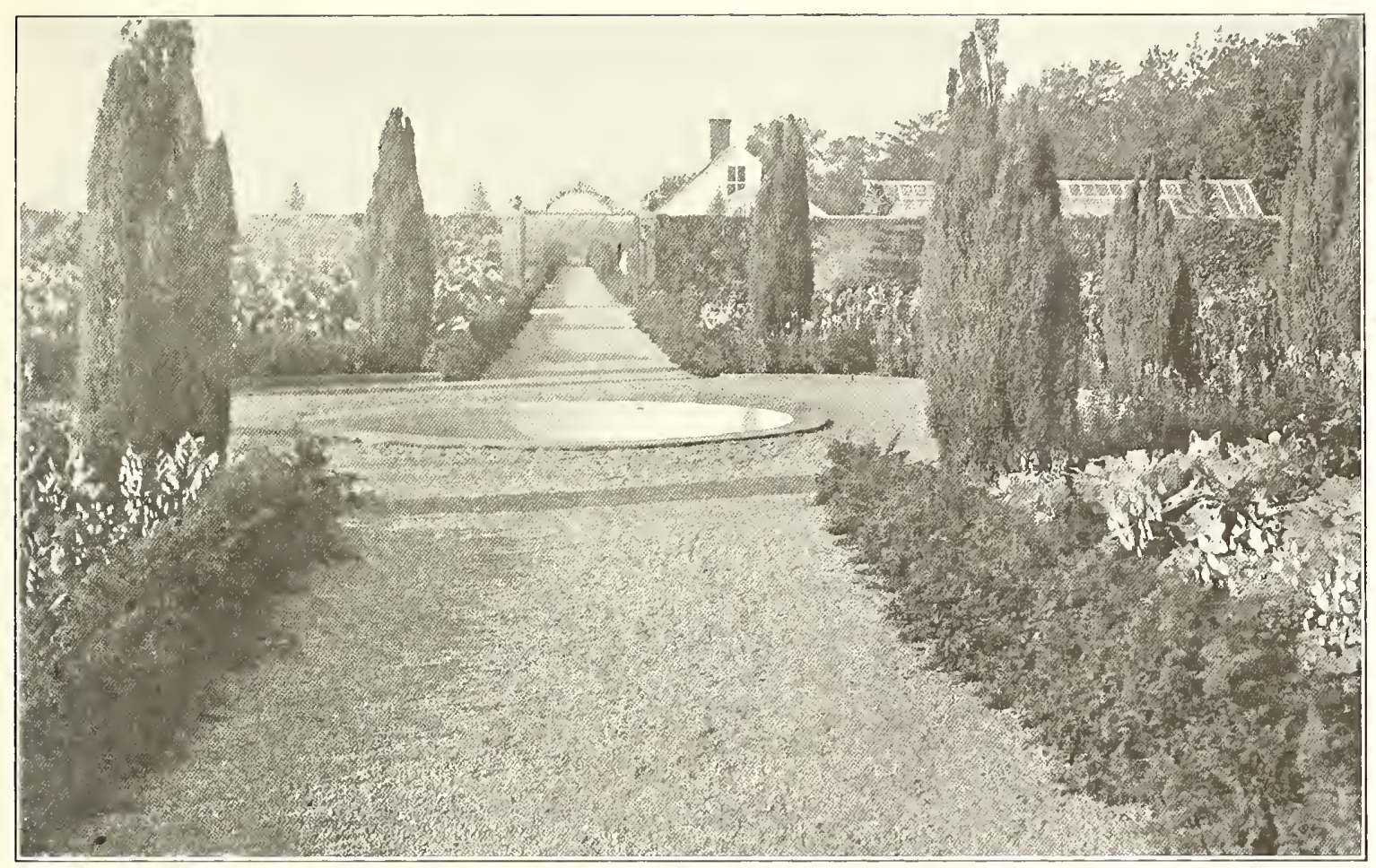

"The Farms"

PLATE 126

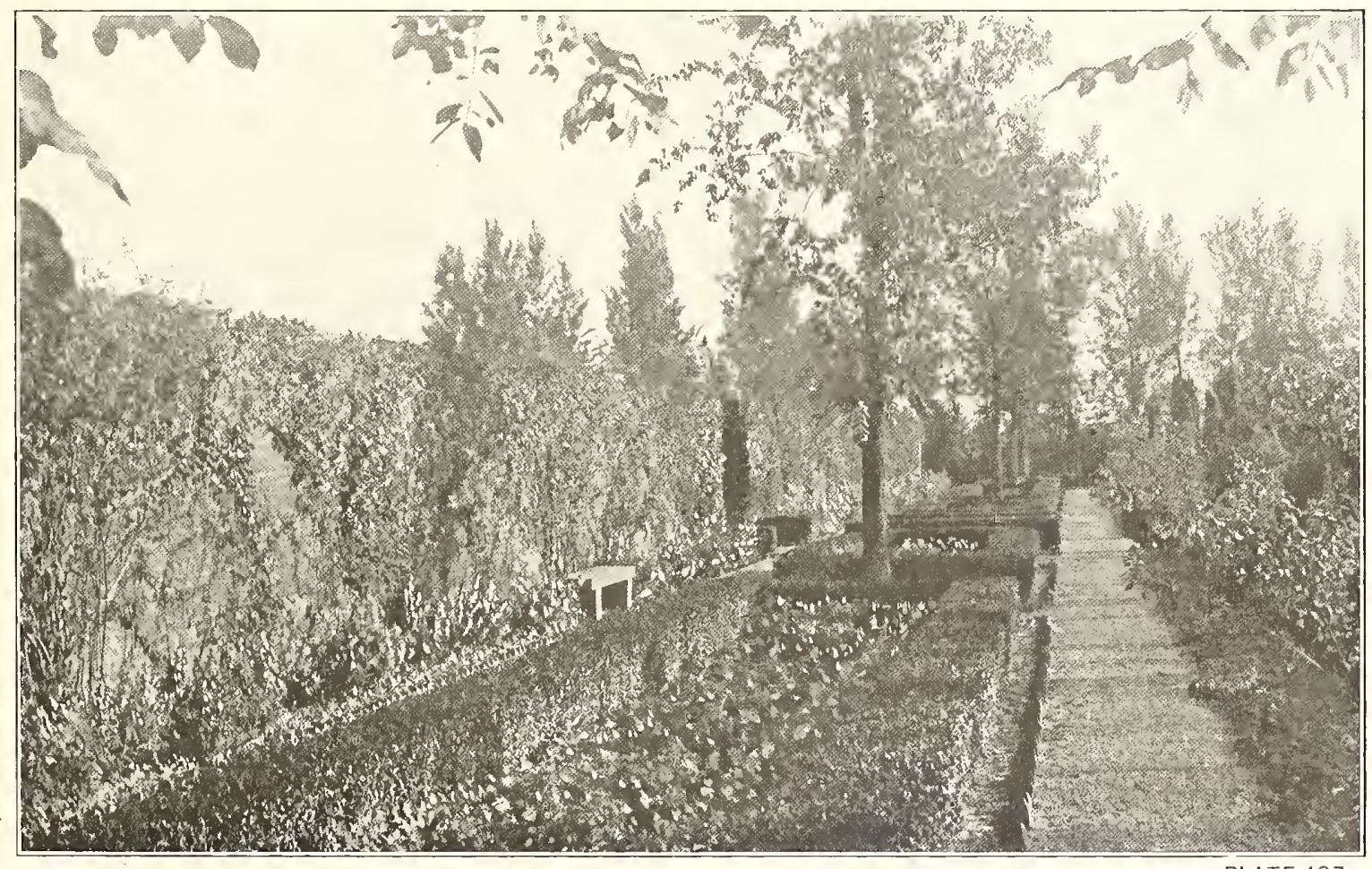

"The Farms," Monticello, Ill. Robert Allerton, Esq.

PLATE 127 



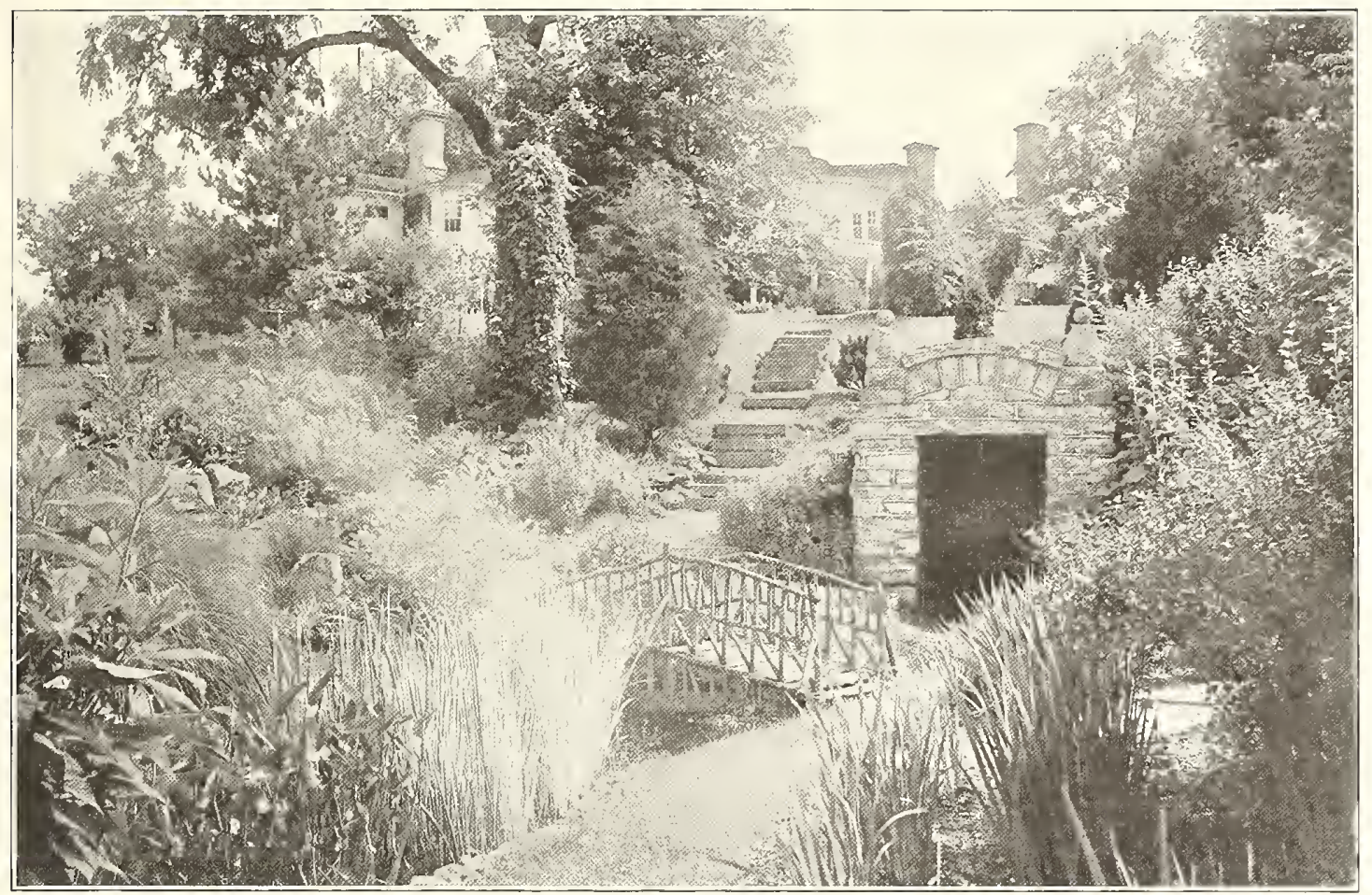

The rock garden, "Englishton Park"

PLATE 128

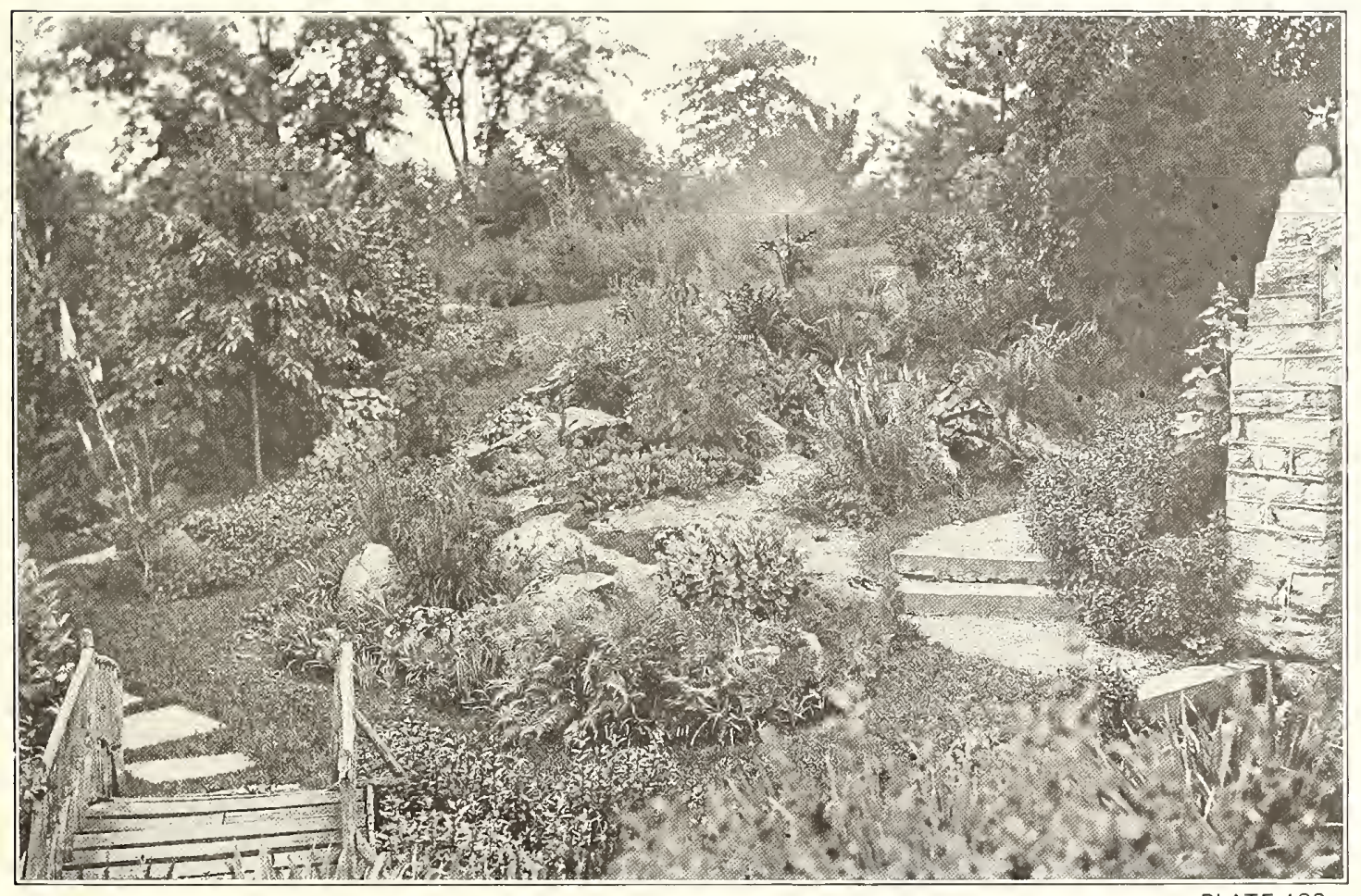

The rock garden, "Englishton Park," Lexington, Ind. Mrs. W. E. English 



\section{XIII}

\section{OHIO}

The difference is slight between the climate of Ohio and other States of its latitude in the East and middle West. While there is no mountainous region, northern Ohio has the advantage of a great lake as its border. On a line with central Connecticut, the temperature of Cleveland is similarly favorable to flower growing, and garden enthusiasts are increasing. Like most of the Middle States, the country is rather flat and the soil fertile as a rule. But, except on the lake shore, the gardens suffer more or less from the hot weather and scarcity of moisture.

In the northern half of Ohio spring bulbs appear simultaneously with those in northern New Jersey, and the later plants follow in the same succession. The southern half of Ohio is in the latitude of Maryland and its climatic conditions are almost similar. The spring and June gardens in the middle West give the best satisfaction. The climate is variable, as it is elsewhere throughout the country.

One charming illustration conveys some idea of the garden at Gwinn, which is eight miles from Cleveland, 


\section{BEAUTIFUL GARDENS IN AMERICA}

and undoubtedly the most notable in this State. By early April the spring garden blooms with Hepatica, Crocus, Chionodoxa, Scilia, Sundrops, Pansy, English Daisy, Spring Beauty, Bloodroot, Trillium, Cypripedium, Violet, Tulip, Hyacinth, and Daffodil, followed soon by many later garden favorites. Sufficient water is supplied to carry the bloom safely through midsummer and September, and year by year the beauty of this garden is increasing with the maturing of its trees and shrubbery, and all that tends to complete the dignity of so noble a design.

So artistically wrought are all the various features contributing to the beauty of the Clifton garden that choice of illustrations is made difficult when selection is limited to so few. This fact explains the omission of the little flower garden which even though charming must give place to the accompanying remarkable views.

Not far from Cleveland Shadyside, on the lake, is another place of interest to flower lovers, and here a small formal garden has been recently completed in addition to the older water garden. This delightful spot is worthy of particular attention not only on account of the variety of plants adorning its banks, but for its picturesque setting as well.

Indian Hill offers a glimpse of a fair little garden, with no suggestion of display; a vine-covered bower surrounded with flowers, - a creation of simple loveliness. 


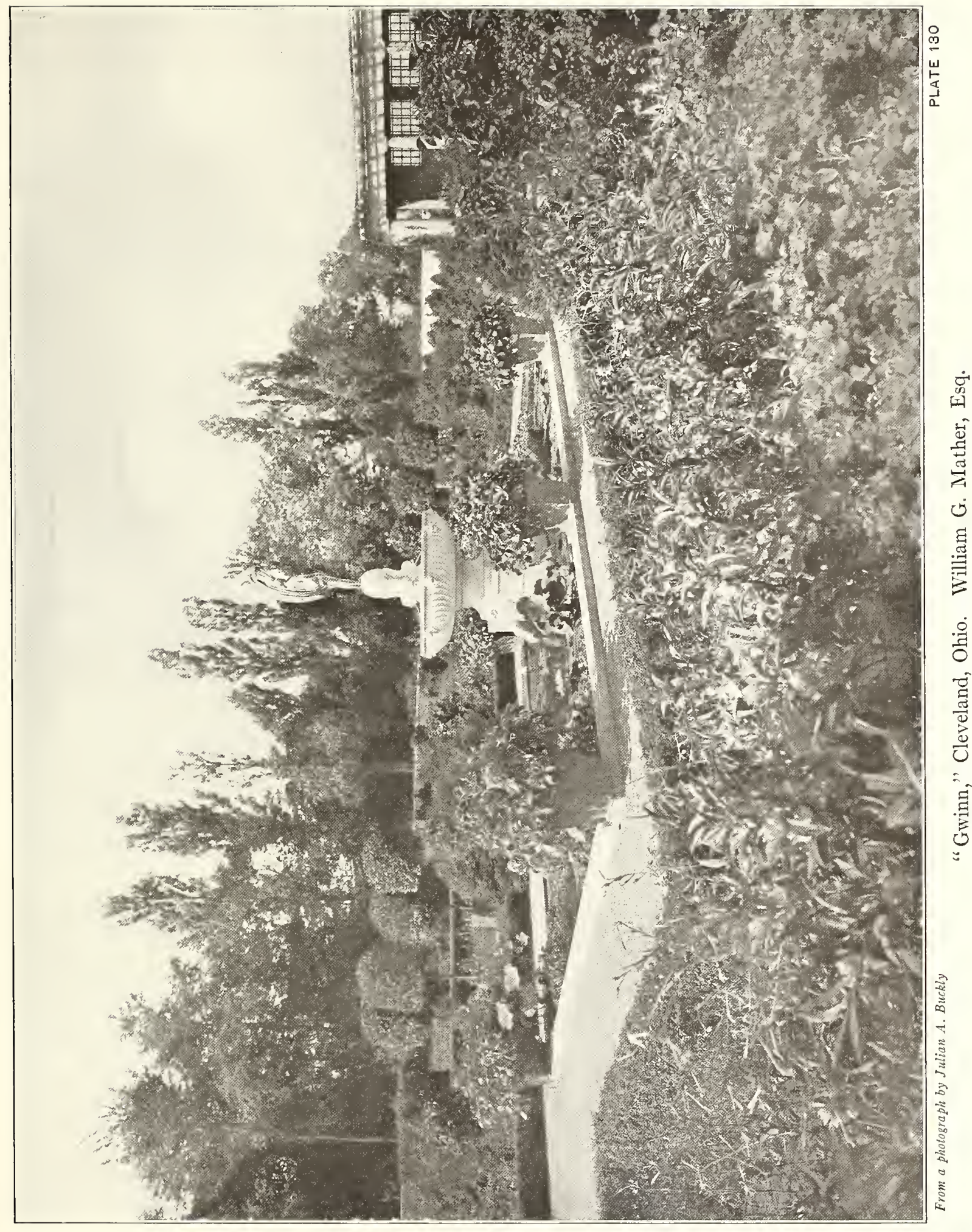





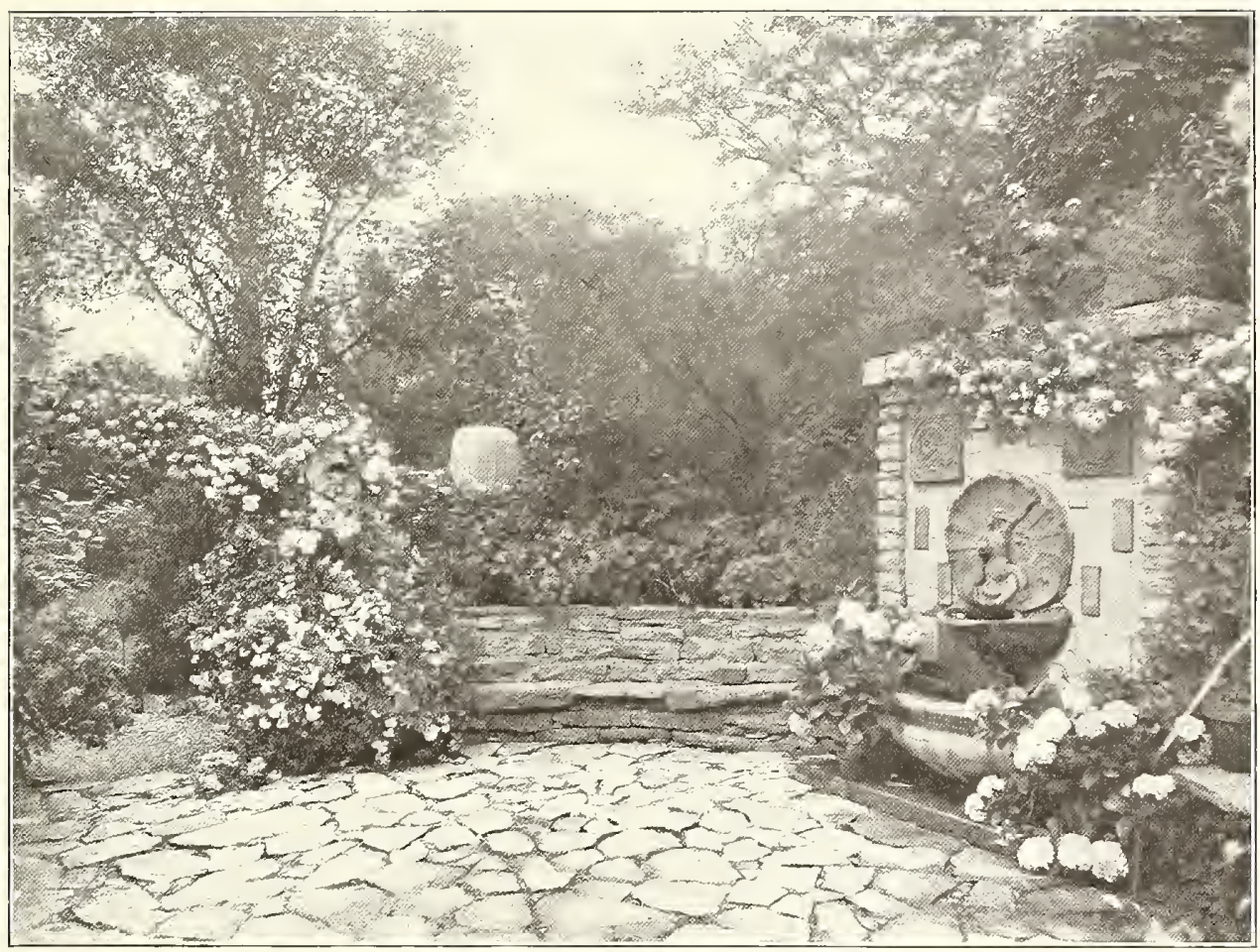

A picturesque spot in Mrs. Taft's garden

PLATE 131

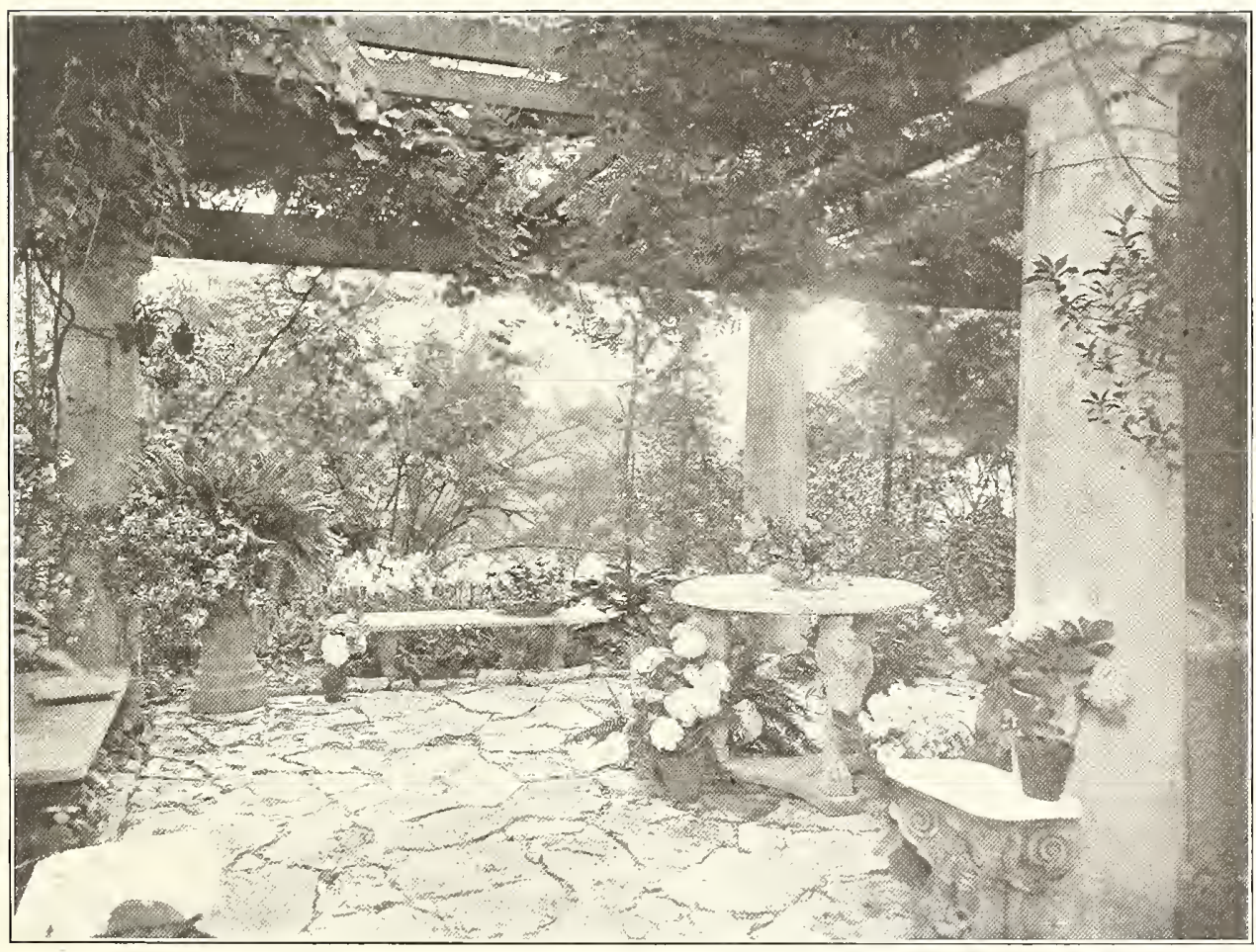

A corner in the pergola

PLATE 132

Clifton, Cincinnati, Ohio. Mrs. Samuel H. Taft 



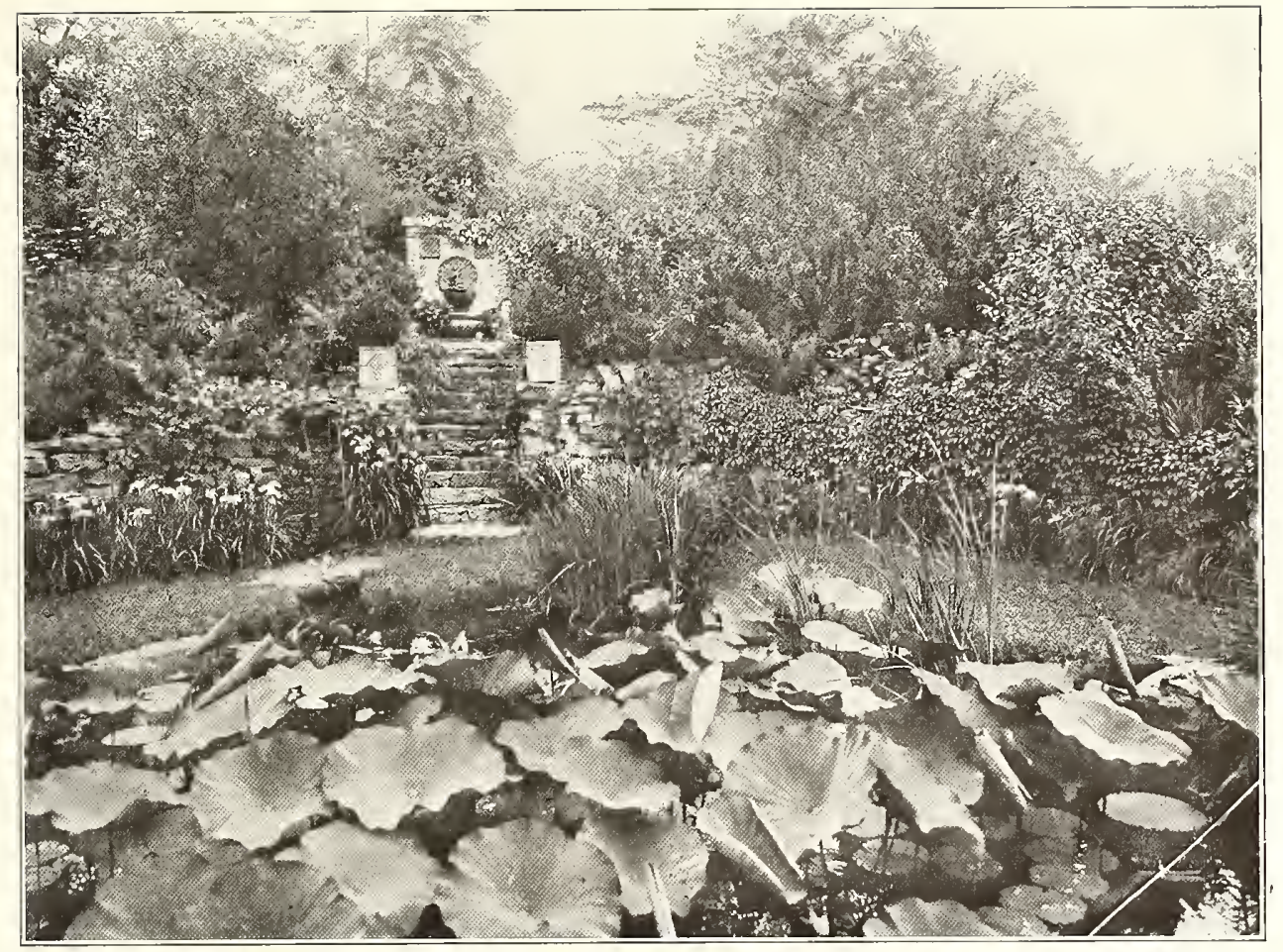

The water garden

Clifton, Cincinnati, Ohio. Mrs. Samuel H. Taft

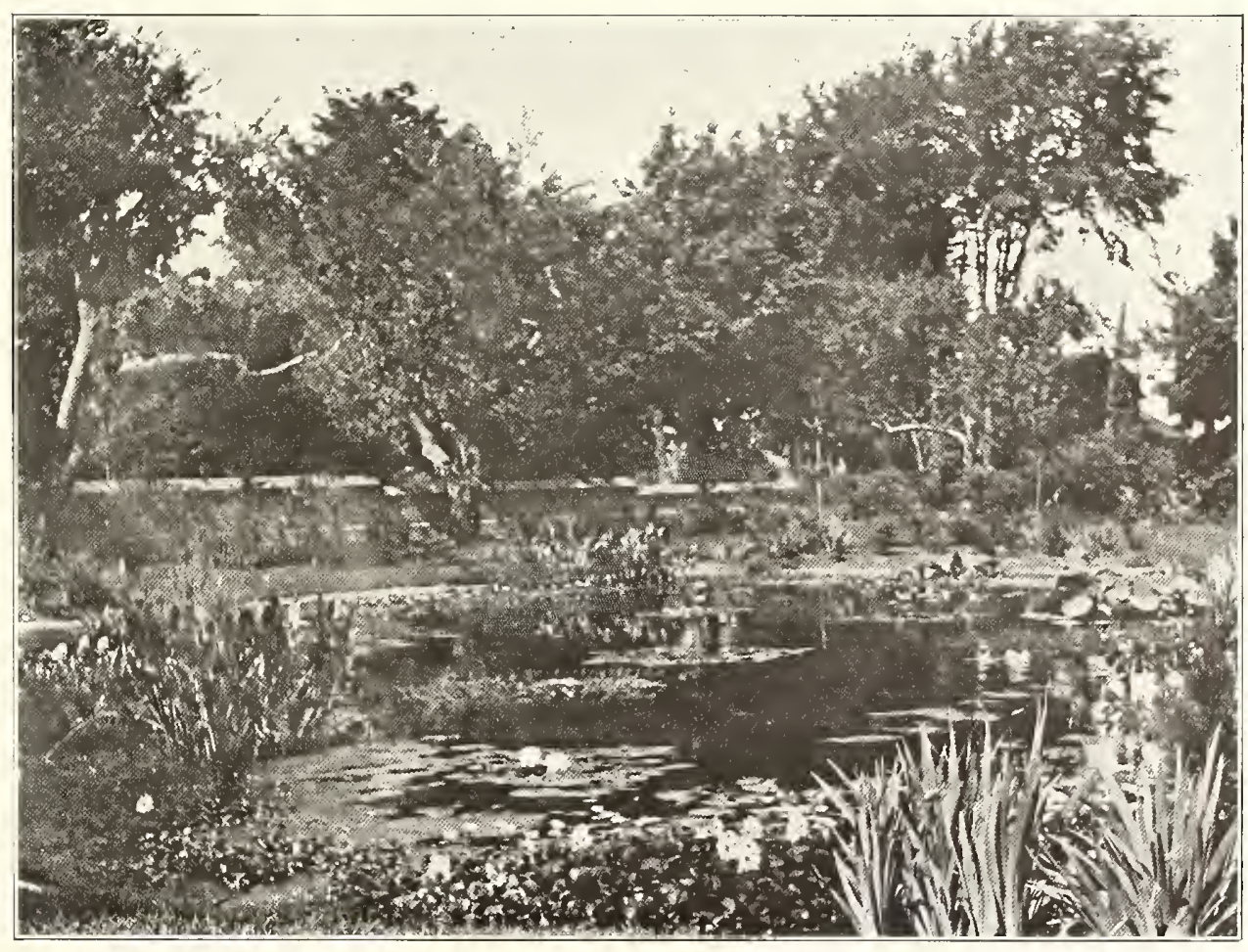

The water garden

PLATE 134

"Shadyside," Painesville, Ohio. Mrs. H. P. Knapp 



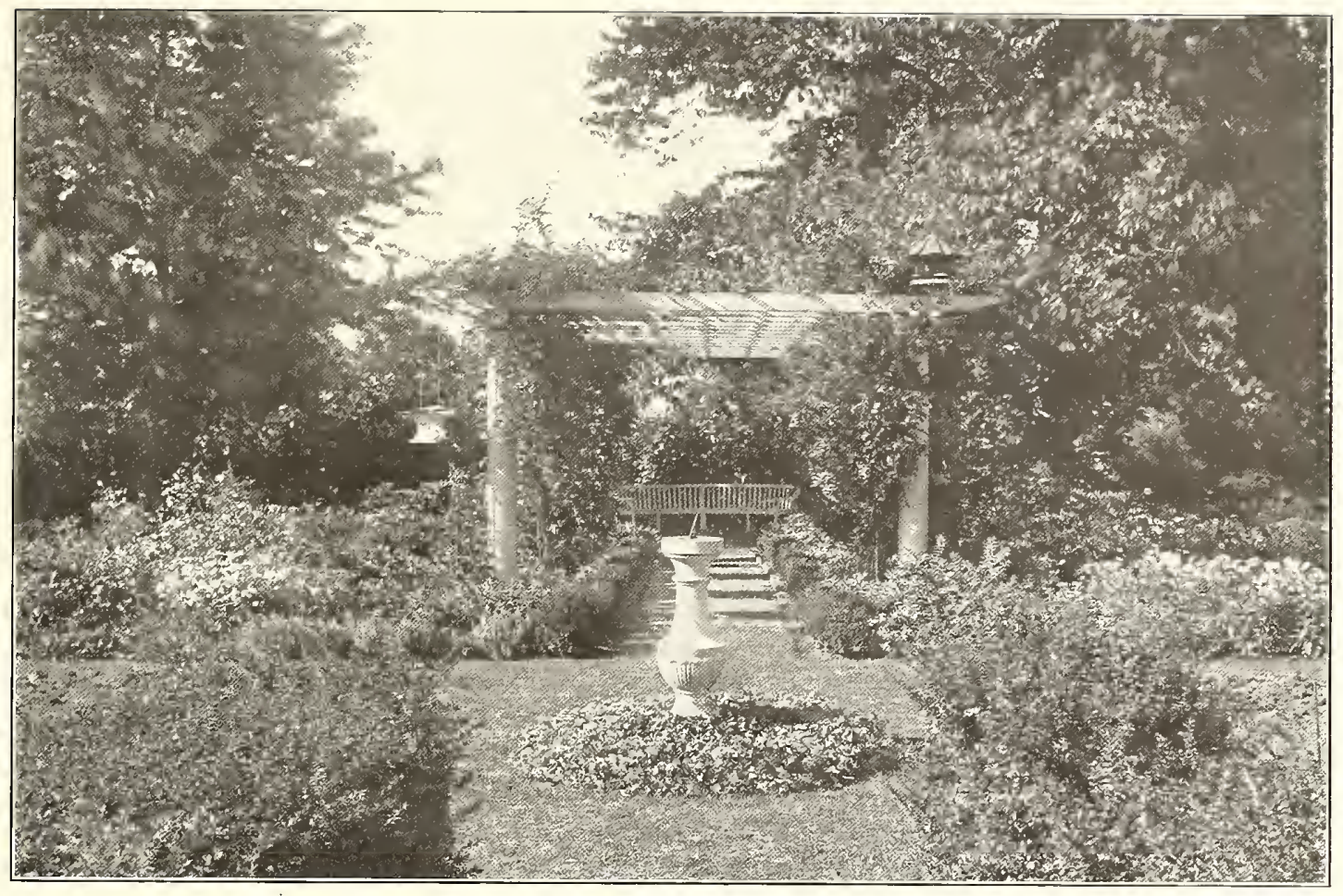

"Indian Hill"

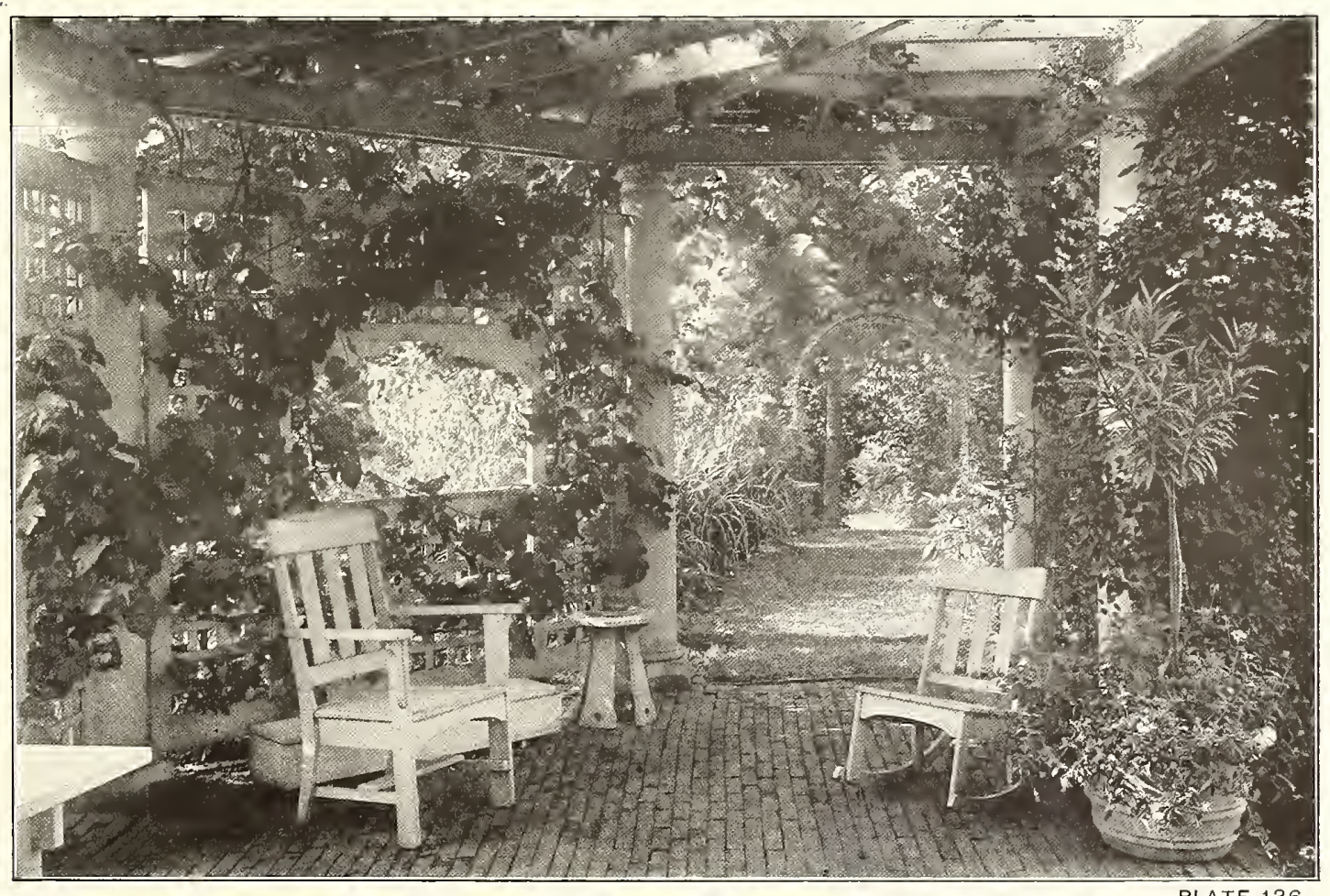

"Indian Hill," Mentor, Ohio. Mrs. John E. Newell 



\section{XIV}

\section{MICHIGAN AND WISCONSIN}

Favored indeed are the gardens of these States, which border on the Great Lakes, some five hundred and eighty feet above sea-level. The country in most parts is fertile and flat, with a climate superior to that of New England in summer, and winters equally as cold. To quote our well known garden friend, Mrs. Francis King, of Alma, in central Michigan: "We have a very fine summer climate, most favorable to gardening; no humidity whatsoever, but dry and bracing, and while a short summer, a merry one for flowers. We must plan for a late spring, and frost is due in early September; but when we have learned these things it is very simple to arrange for them. Our rainfall is usually sufficient, and we practically never suffer from the heat. Hardy Chrysanthemums need a very sheltered position in winter. At Detroit, one hundred and fifty miles southeast of Alma, the trees are in spring foliage almost ten days earlier, partly owing to the distance southward and partly to the warming influence of Lake St. Clair."

The garden at Orchard House, Alma, so vividly described in "The Well-Considered Garden," is too familiar to most gardeners to need description. Briefly, the plant- 


\section{BEAUTIFUL GARDENS IN AMERICA}

ing over the large space is all balanced in predominating colors of rose, lavender, white, and palest yellow. Gray foliage and white flowers are freely used, and through the entire summer there is not one week when the whole garden is not gay with flowers from June until frost.

To the northeast of Alma is the lovely garden at Garra-tigh, where Daffodils bloom, as in Alma, three weeks later than near the city of New York. Bay City is in the latitude of Portland, Maine, and central Oregon. This attractive garden shows the effective combination of flowers and trees so well arranged that the trees are not detrimental to the vigor of the plants, and the sunny garden space is doubly radiant by contrast, lying within the trees' encircling shadows. Garra-tigh is the Gaelic for House with the Garden.

Near Detroit, at Fairlawn, Grosse Pointe Shores, on Lake St. Clair, where the country is flat and fertile, there is another delightful place of interest noted for the abundance of flowers covering several acres of land. The accompanying photograph was made in early September, when the best of the bloom had passed. In June and July the place is a glory with Lilies, Columbine, and Delphinium that are counted in hundreds, and earlier there are Tulips and Daffodils by the thousands. Behind the broad borders that edge the walks vegetables grow in great quantities. Early Tulips come the first week of May, late Tulips about May 20. Climate and soil combine to simplify the gardening tasks in this productive country. 


\section{BEAUTIFUL GARDENS IN AMERICA}

The House in the Woods, on Lake Geneva, Wisconsin, has a beautiful garden so well planned that it seems like an outdoor room to this charming villa. The planting scheme is moderate, easily maintained, and yet with beds broad enough to include without difficulty the plants for a long, continuous bloom. Opposite the house the picturesque studio, standing out against the wooded background, borders the garden on this side so that it lies within an enclosed court. 
b 


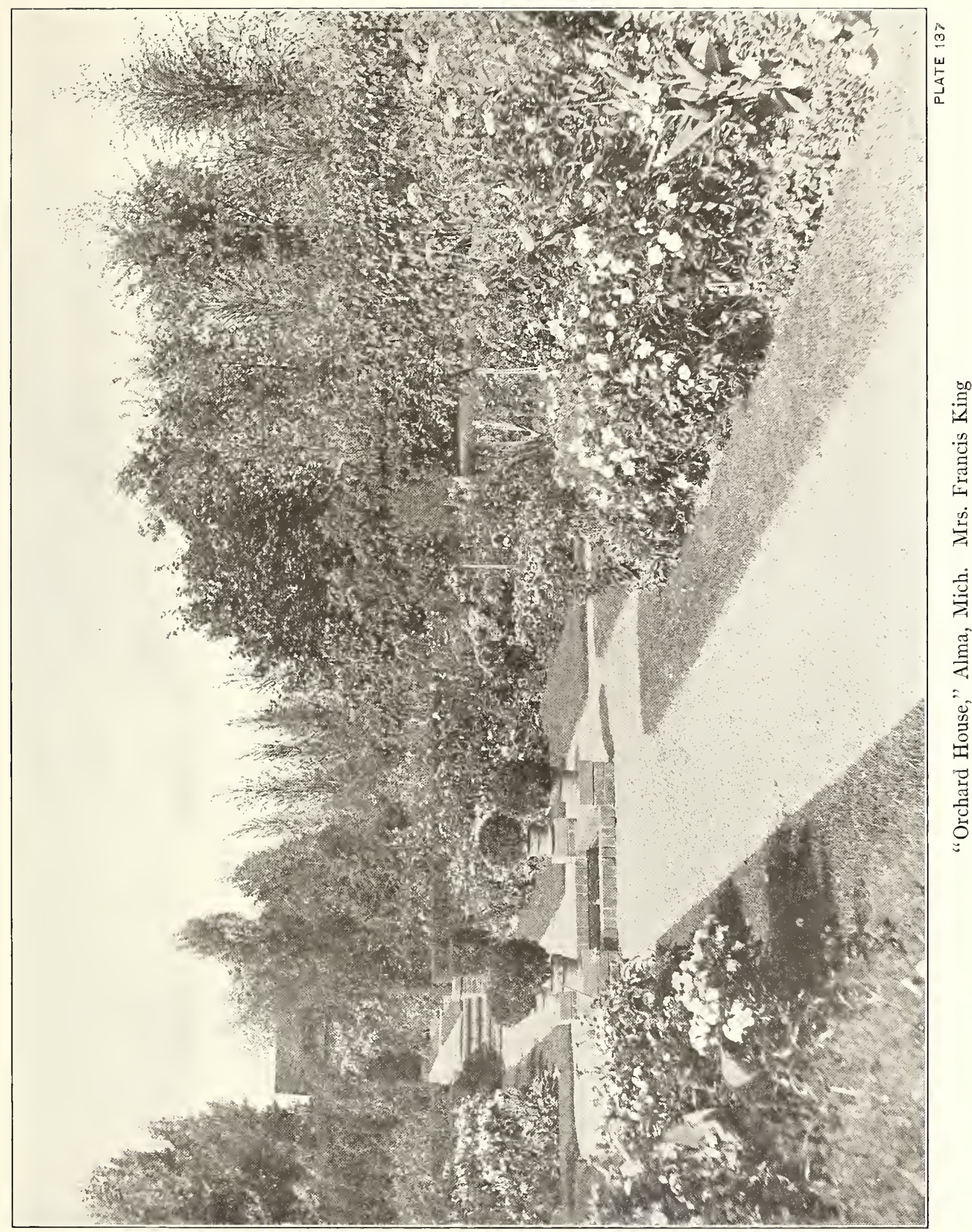





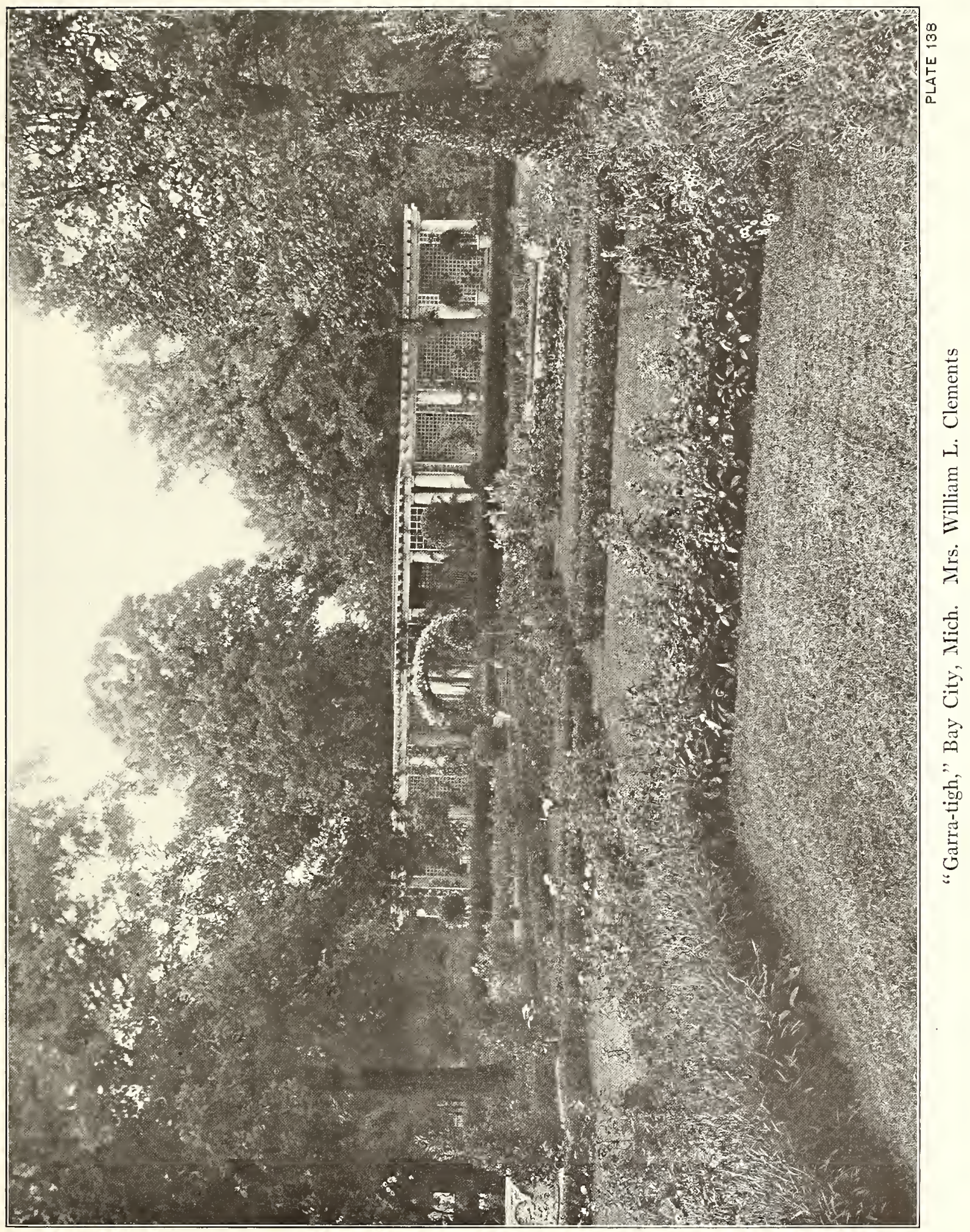





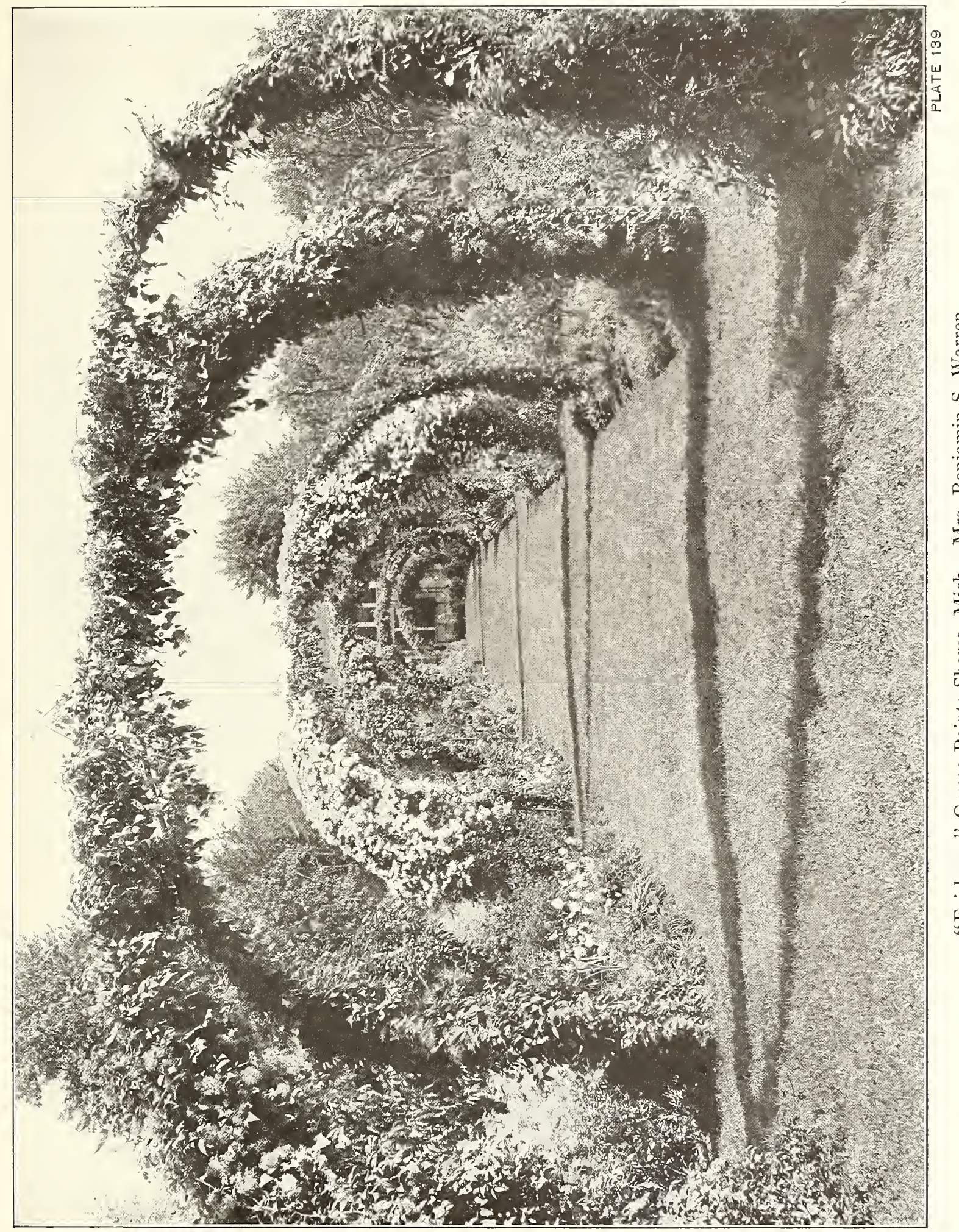

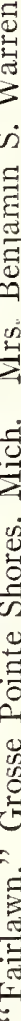





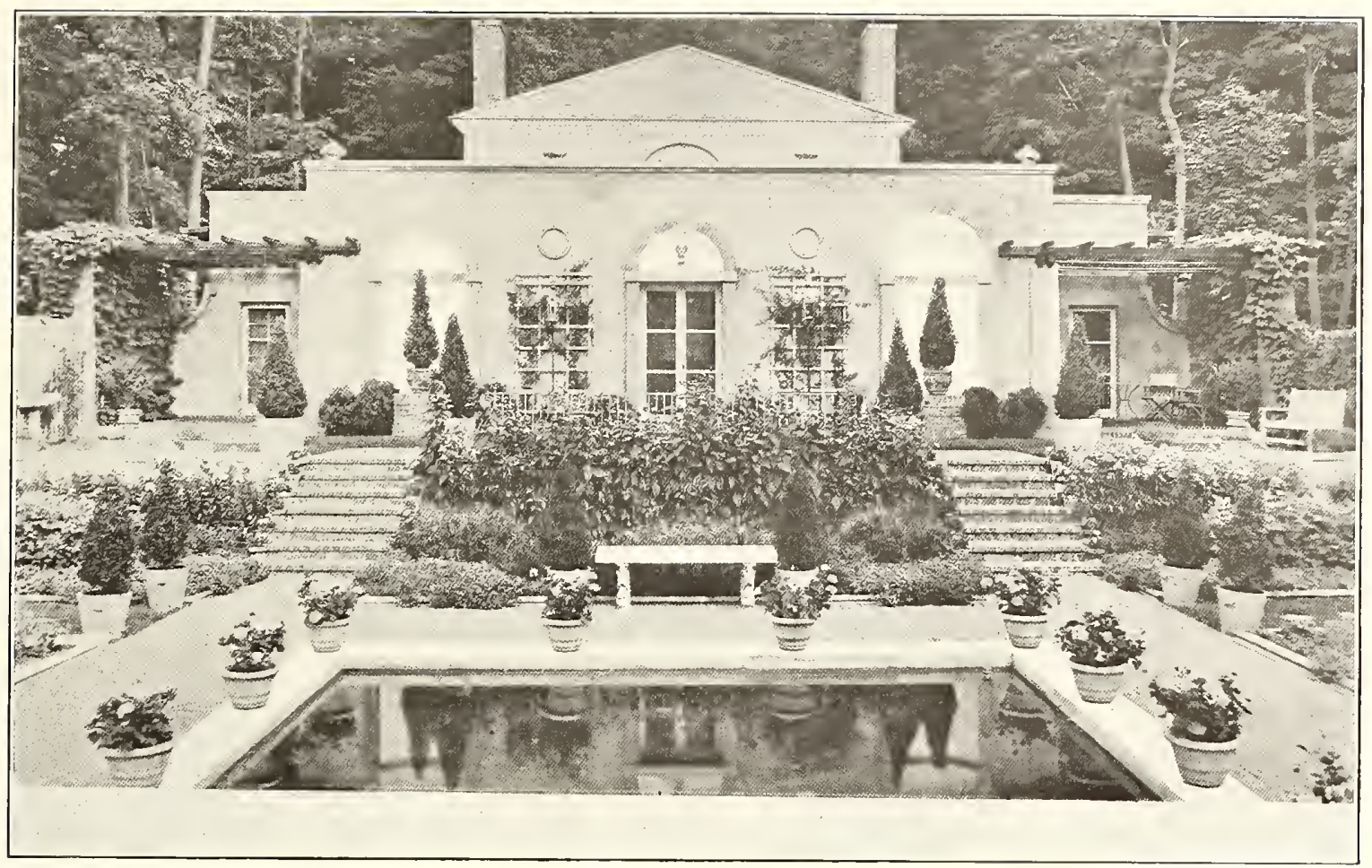

Studio from main house

PLATE 140

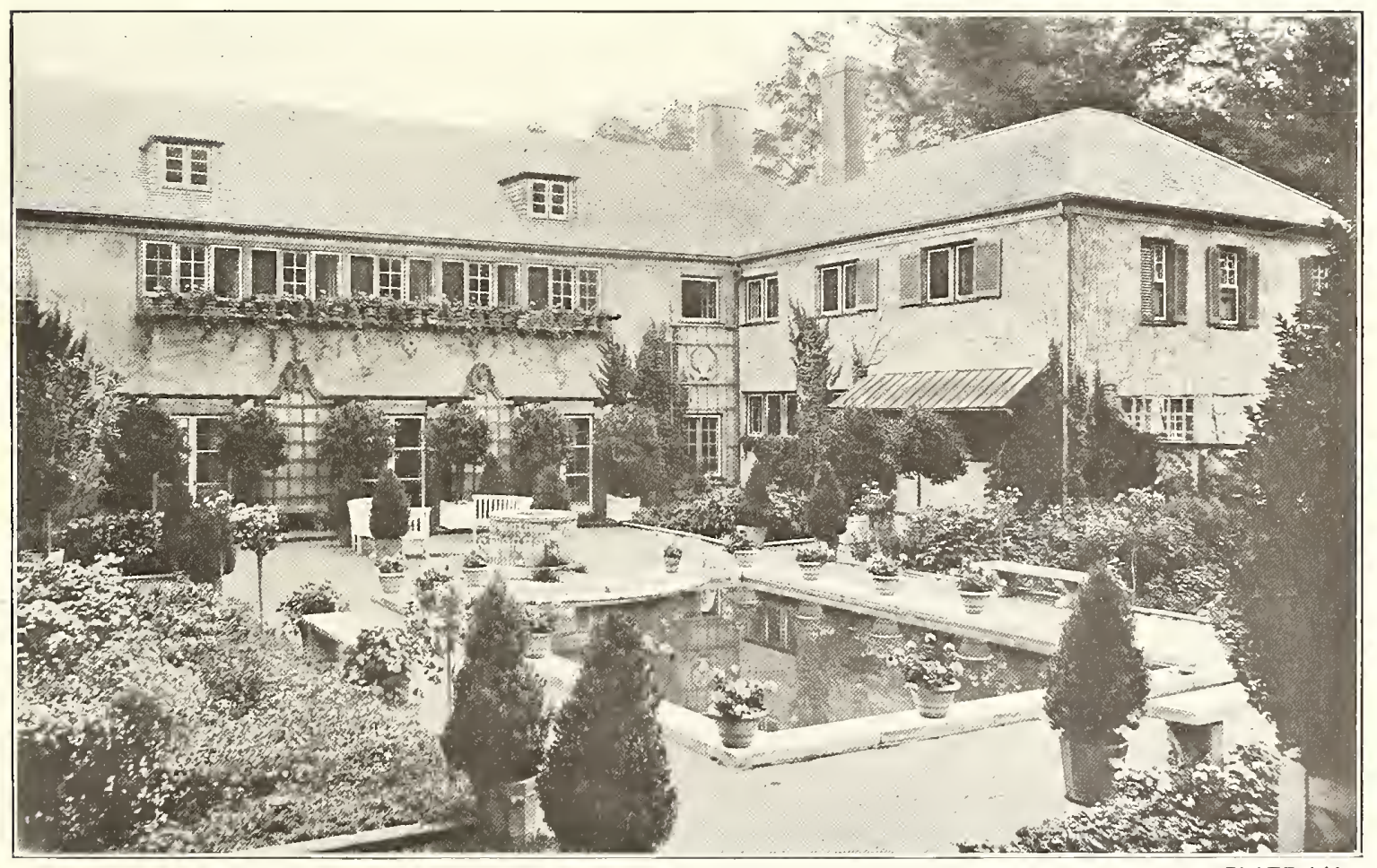

Court from studio terrace

PLATE 141

"House-in-the-Woods," Lake Geneva, Wis. Frederic Clay Bartlett, Esq. 



\section{XV \\ NEW MEXICO}

The mountainous States of the West, from Montana to New Mexico, from Colorado almost to the Pacific, have a climate of their own, varying naturally according to latitude. A resident of Las Cruces, New Mexico, writes: "The first killing frost is usually to be expected from the 7 th to the 25th of October, very often it is much later, and we have had tomatoes till December with the slightest possible protection. Many flowers in a sheltered position bloom in winter, such as Calendula, Violets, Wallflowers, and Pansies. The highest ordinary summer thermometer is ninety-two to ninety-eight degrees. The lowest usually in winter is fifteen degrees - occasionally it has gone down to fifteen or twenty degrees below zero, but that is most exceptional. The climate is extremely dry. Most of New Mexico is at a high altitude - we are about three thousand eight hundred feet above sea-level here.

"As some plants blossom through the winter, it is hard to say when the garden begins to bloom. But about the middle of March we have Crocuses, followed the 1st of April by Jonquils, Narcissus, Tulips, and other bulbs, 299 


\section{BEAUTIFUL GARDENS IN AMERICA}

also German Iris, Lilac, Periwinkles, Cornflower, Mignonette. In the mountains near-by the California Poppies bloom at the same time. Then about mid-April come Tea Roses - and at the end of April or soon after the Peonies and Sweet Peas. The 1st of May or a little later Honeysuckles, Phlox, Snapdragon, Zinnias, and annual Larkspurs appear. Almost everything that is not extremely tender can be wintered in open ground without protection. Tender annuals should be planted out about the end of March. I transplanted some things last year the end of April, and the noonday sun was too much for them, though I shaded them for some time. We plant seeds of Pansies, Asters, Sweet Peas, etc., in the fall for best results."

The garden at Mr. Barker's mountain home is delightfully fitted to its surroundings, where nature is supreme and all else studied simplicity. Flowers revel in their freedom without the restriction of conventional beds. Flowers, nature, and the simple life of the Southern hills is the message from this distant home. 


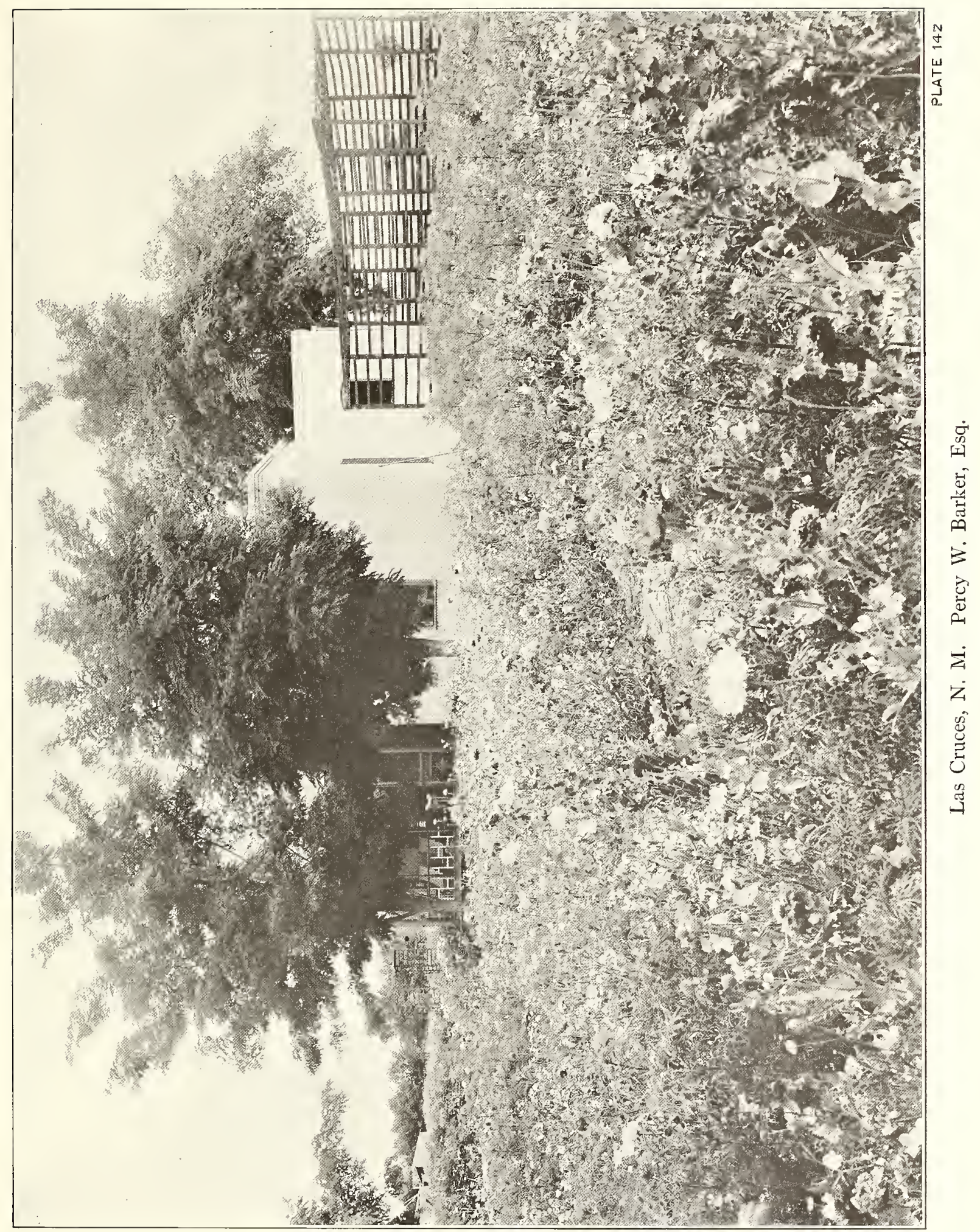





\section{XVI}

\section{CALIFORNIA}

The garden section of this State extends the length of its coast, and possibly fifty miles inland, and much is conveyed in a few words when it is described as one garden throughout this whole region. In the hill country mountains are admirable settings to tropical gardens, and from there to the sandy shores a delectable climate with prevailing westerly sea-winds encourages phenomenal growth of the choicest plants.

Southern California is particularly blessed with a clear, dry, and balmy climate. Quoting an authority in Santa Barbara: "There is practically no frost in southern California; in the north there is some. There are flowers in our gardens at all times of the year. Tulips bloom in February and March; Daffodils, German Iris, and other hardies from February to May; also Lilies-of-the-Valley, which latter are more scarce on account of the dryness of the atmosphere. From March till autumn there is bloom from Sweet William, Phlox, and many others of their kind, while Geranium, the common Marguerite, and Heliotrope grow all the year around and become large bushes. Roses cover the tops of some villas; Cosmos, California 303 


\section{BEAUTIFUL GARDENS IN AMERICA}

Poppy, Zinnia, Nasturtium, and Stock are among the favorite annuals; and all, whether hardy or tender, may be planted out in March when the winter rains are over. Some of the favorite exotic shrubs used for their bloom are the Acacias, Genista, etc., Solanums, and Choisia Ternata." Quite common are the great Poinsetta plants and the soft, trailing Bougainvillea, with its exquisite red matching in tone the color of our autumn leaves. Boxwood is little used in this climate. Toward San Francisco and northward it is found in greater quantity. To the south it is replaced by Myrtus communis nanus, Myrtus microphylla, Veronica Andersonii for low hedges; Monterey Cypress, Eugenia myrtifolia, different species of Ligustrum (Privet), which are all evergreen here, Duranta Plumerii, and others.

The highest temperature in Santa Barbara for a few days in fall is about eighty-six degrees Fahrenheit and the lowest in winter is forty degrees for a few days. The summers are very cool. The climate of Santa Barbara is quite similar to Sorrento, Italy, only better. The farther north on the coast the more rain. In Santa Barbara there is sunshine continually, except for the brief period of rain in winter. The warmest months are August, September, and October. From May to August there are fogs at night along the coast which keep the temperature down during the day.

In this paradise of sunshine and flowers are found a bewildering number of wonderful subjects for photography, 304 


\section{BEAUTIFUL GARDENS IN AMERICA}

some of which must give an idea of the favored vegetation of California.

At Kimberly Crest, as in the other views, most conspicuous is the brilliant clearness of the atmosphere. This beautiful country-seat is a sample of many which are built more or less on a similar plan, and especially noted for their profusion of choicest shrubs, trees, and flowering plants.

At Glendessary is found one of California's favorite gardens, where the strong sunshine is moderated by the plentiful use of trees so carefully arranged that the shadows do not disturb the growths of flowers, which bloom abundantly throughout this lovely place.

The flower garden at Piranhurst, named for Saint Piran, an Irish saint, is exceedingly picturesque. The wonderful Greek Theatre, with its wings of tall, clipped Cypress, is without a rival in this country. The design was modelled after one at the Villa Gori, in Italy. This remarkable planting, together with the Roses and other flora in the adjoining garden, combine to make it one of the most famous places on the coast. The owner of Piranhurst is also possessor of the garden at Ross, partly shown in the view of a fountain, with its hill background covered with massively grouped Hydrangeas and Rose vines.

Perfectly complete in every detail is the lovely pool in Doctor Schiffman's garden. It seems more a product of the Old World across the sea, while fitting so happily into the tropical atmosphere of Pasadena. 


\section{BEAUTIFUL GARDENS IN AMERICA}

The marvellous growth of Banksia and Cherokee Roses, the field of Marguerites, and the background of snow-peaked mountains, all so characteristic of California, belong to Cañon Crest Park, an estate well known to many travellers. Wonderful, too, are the Palms that overarch the driveway, and beautiful the gardens and panorama beyond.

The Cactus planting of a San Diego garden is an interesting study in the horticulture of California - this most favored State of the great Union. 


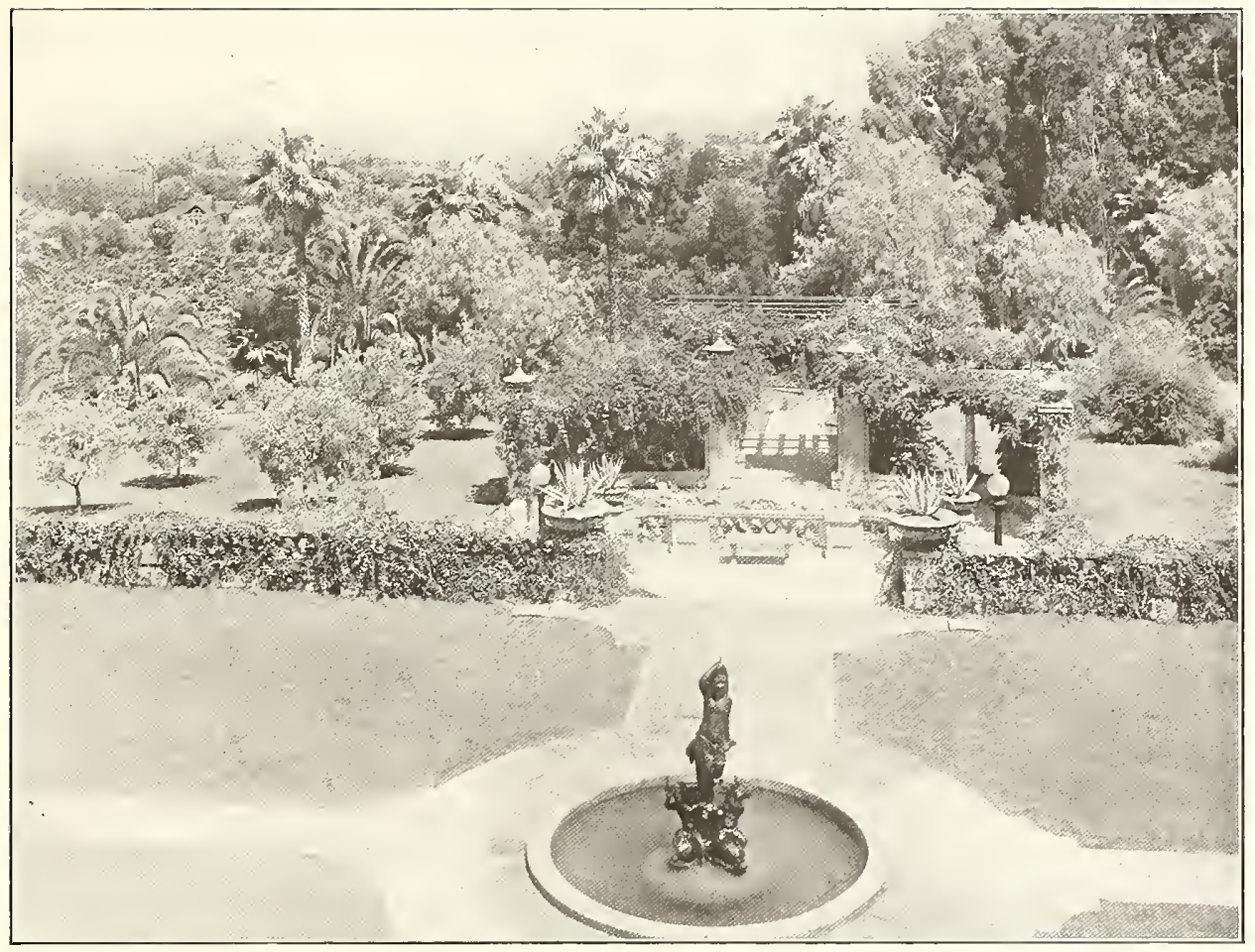

"Kimberly Crest"

PLATE 143

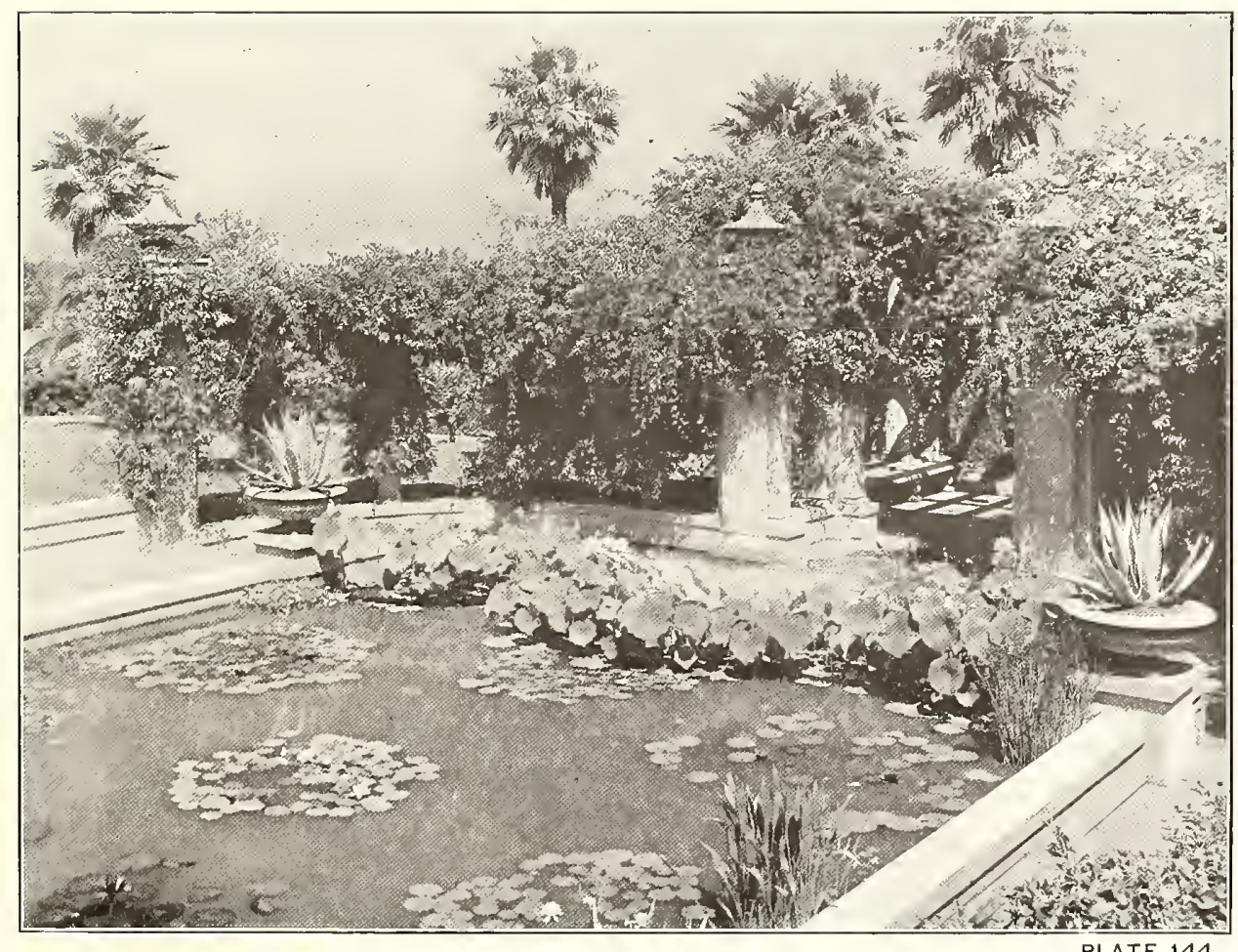

“Kimberly Crest,” Redlands, Cal. Mrs. J. A. Kimberly 



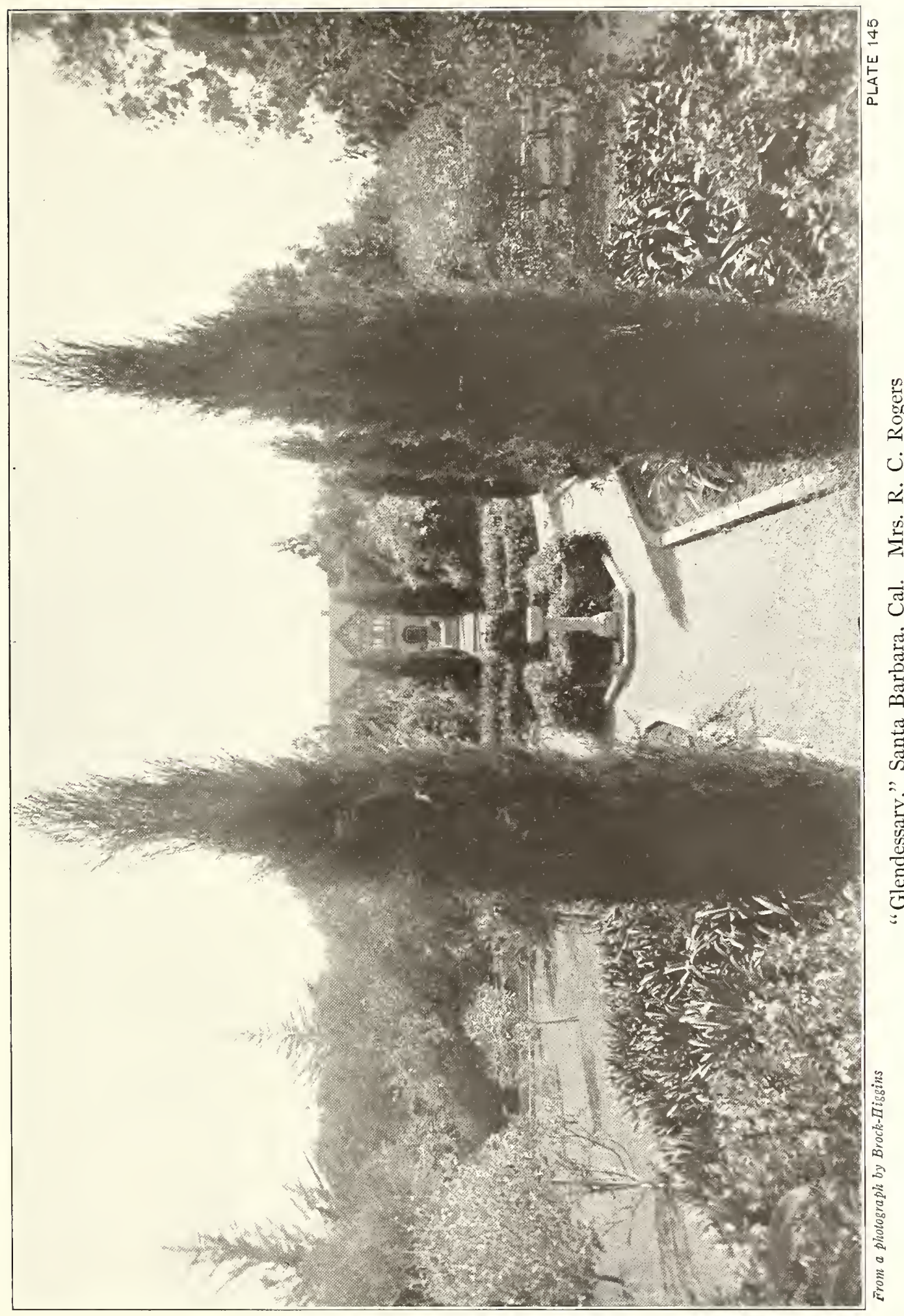





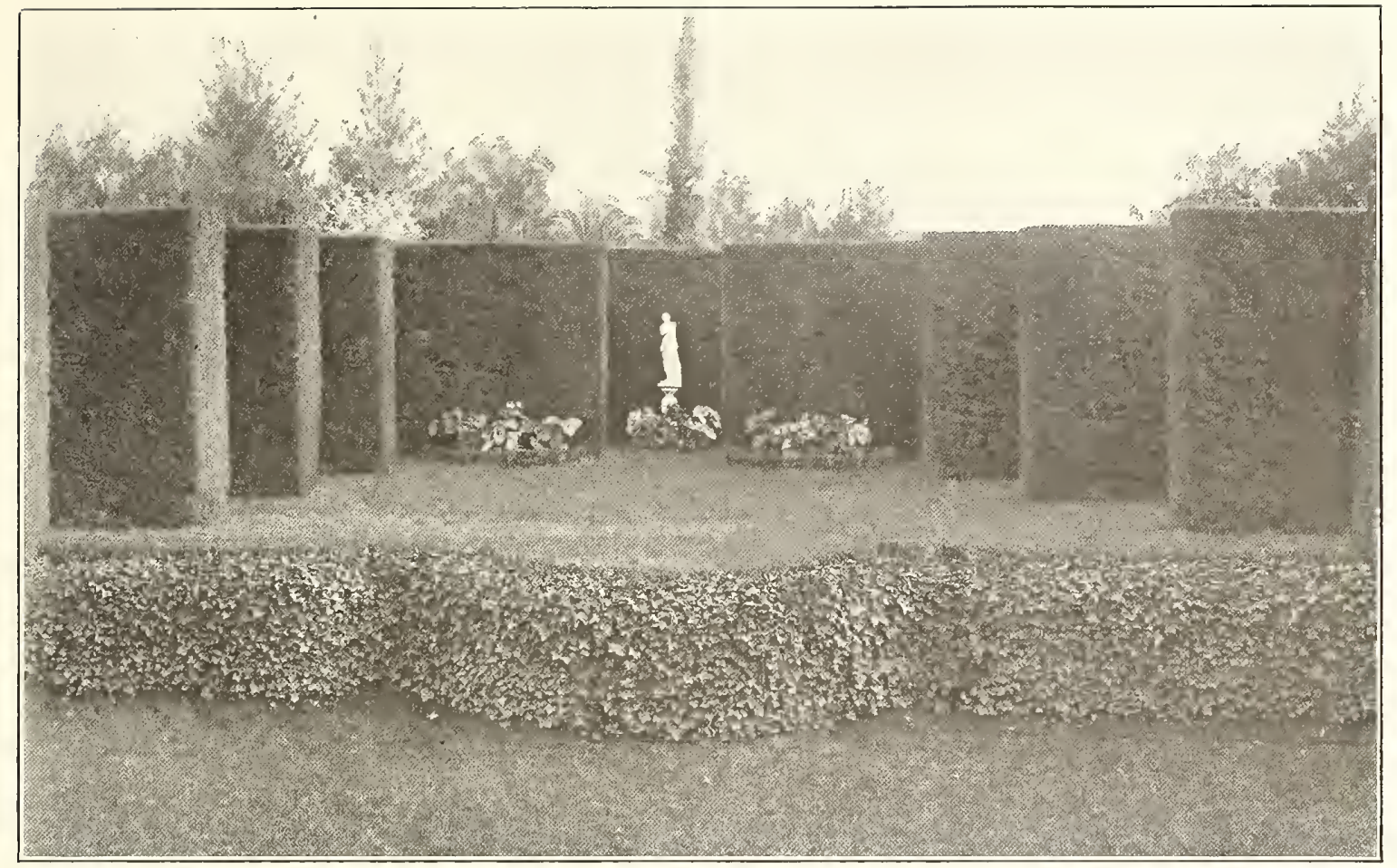

The Greek Theatre - the stage

PLATE 146

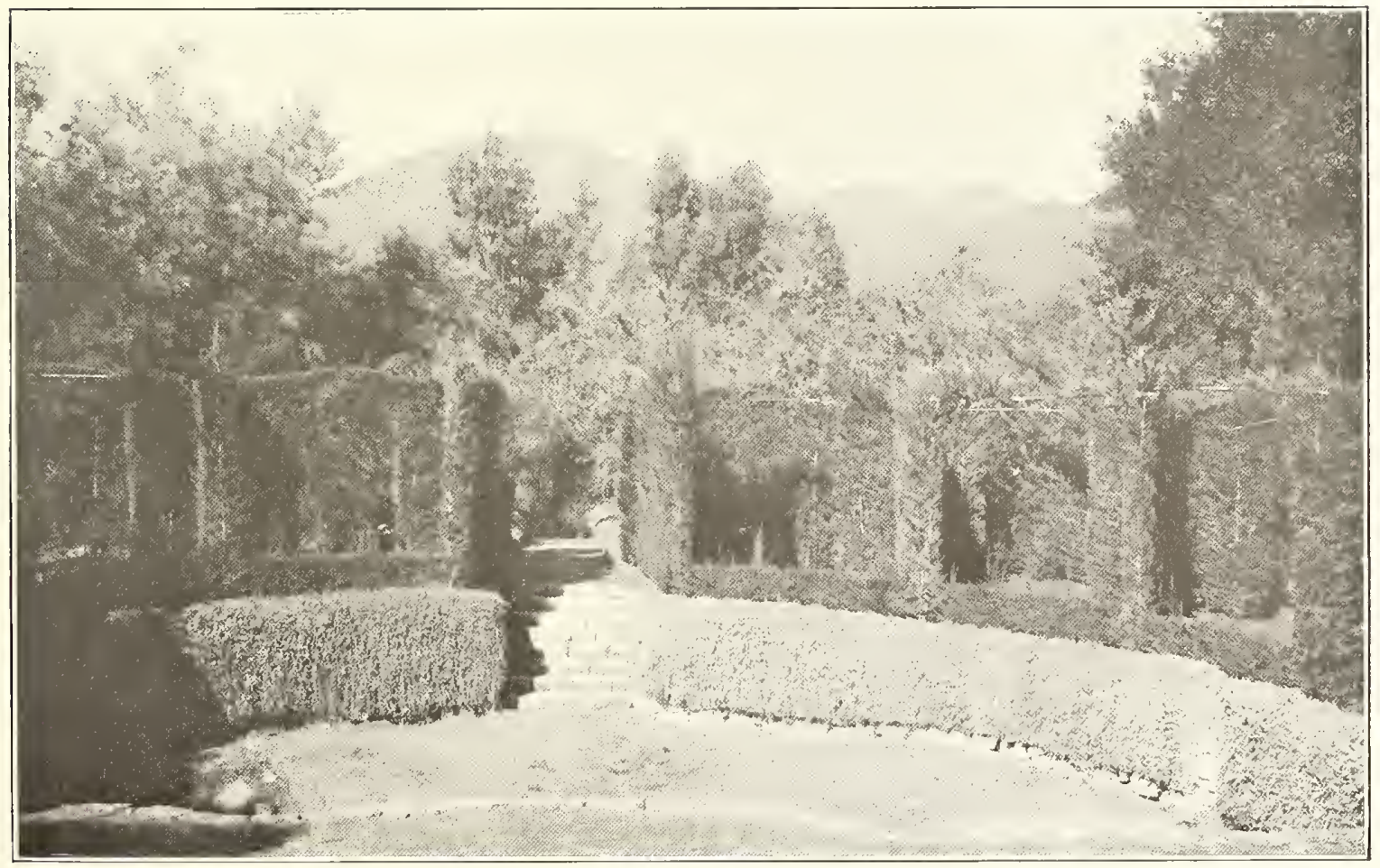

The Greek Theatre - the boxes

PLATE 147

"Piranhurst," Santa Barbara, Cal. Mrs. Henry Bothin 



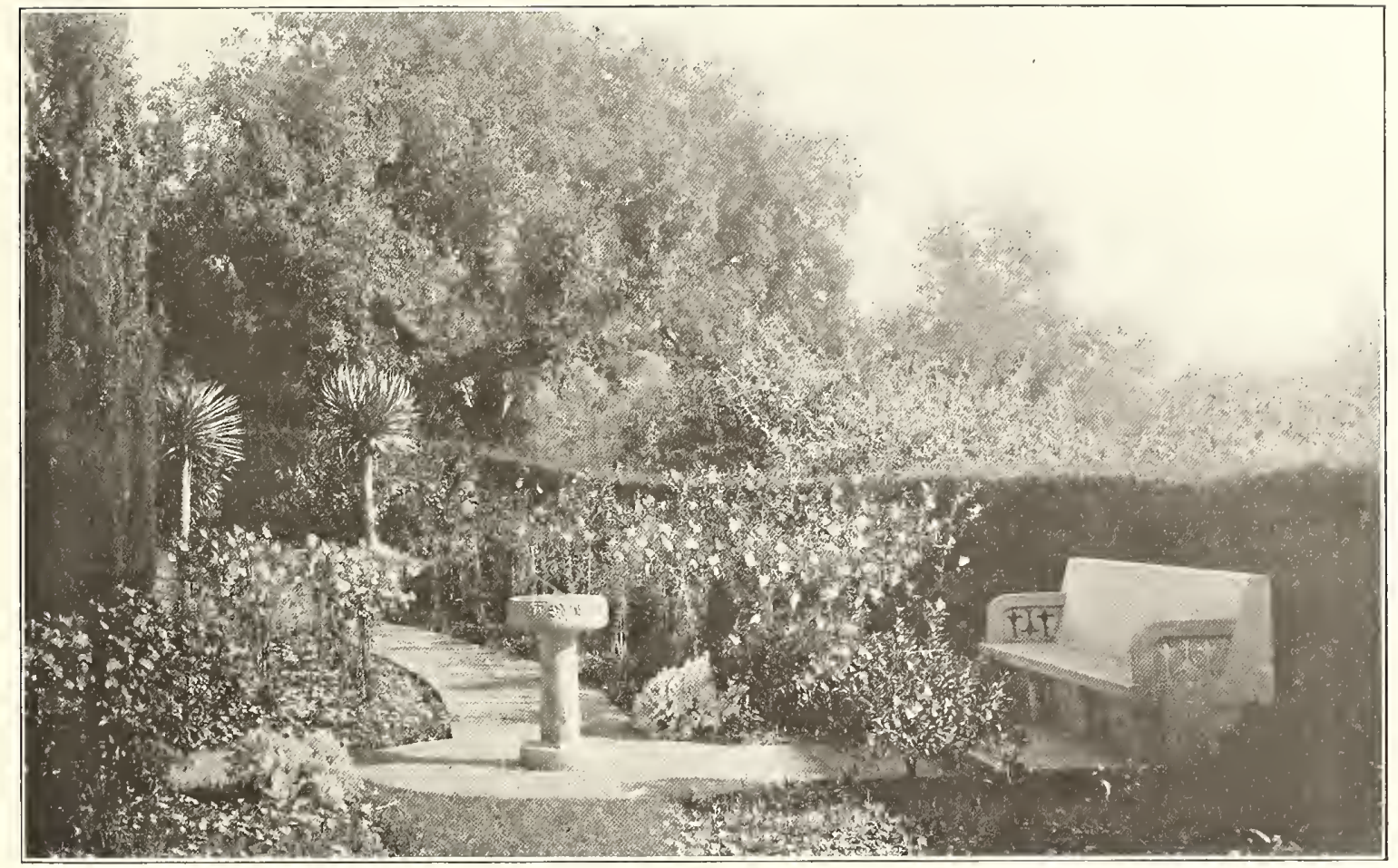

"Piranhurst," Santa Barbara, Cal. Mrs. Henry Bothin

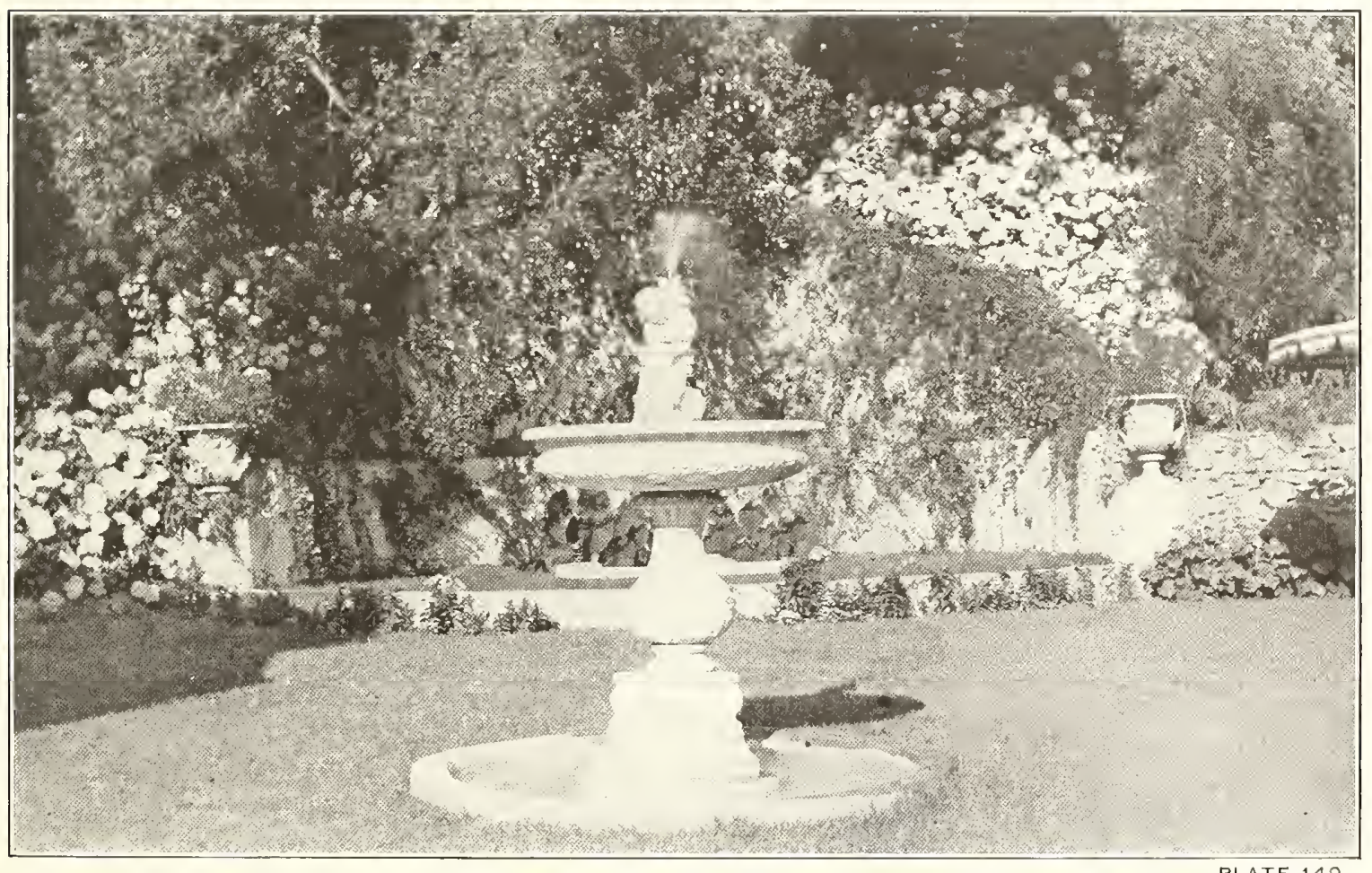

Ross, Cal. Mrs. Henry Bothin 



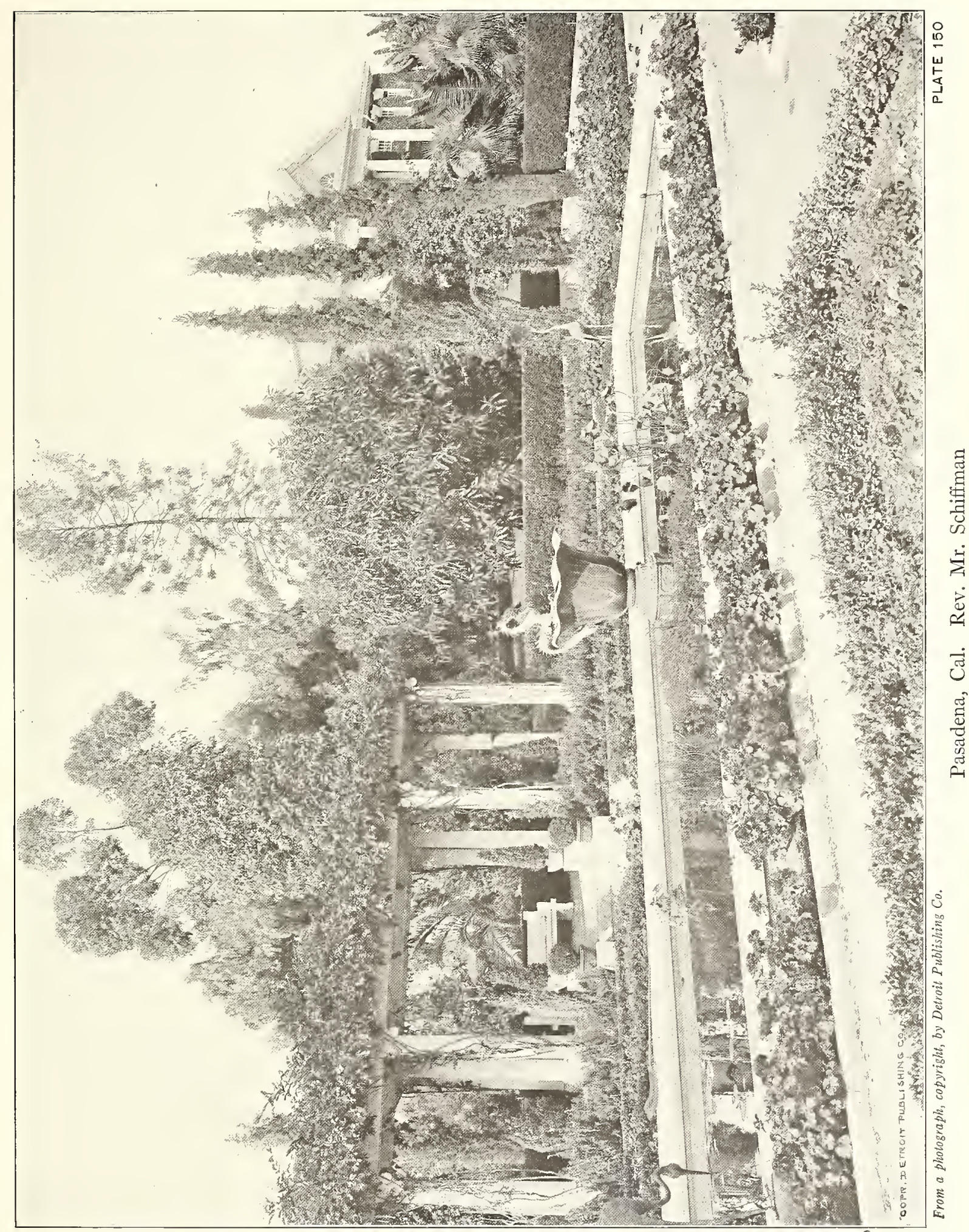




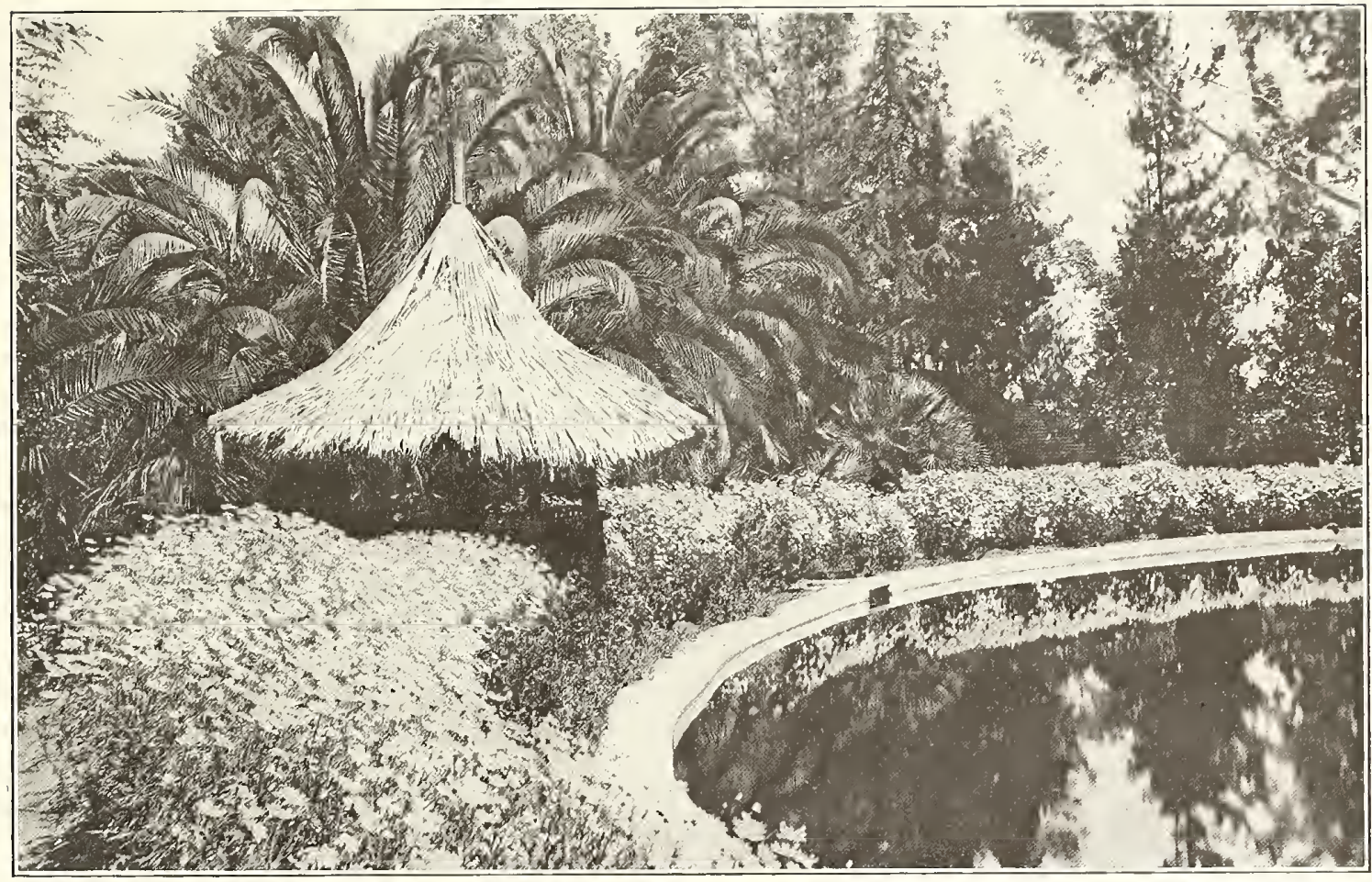

PLATE 151

"Cañon Crest Park"

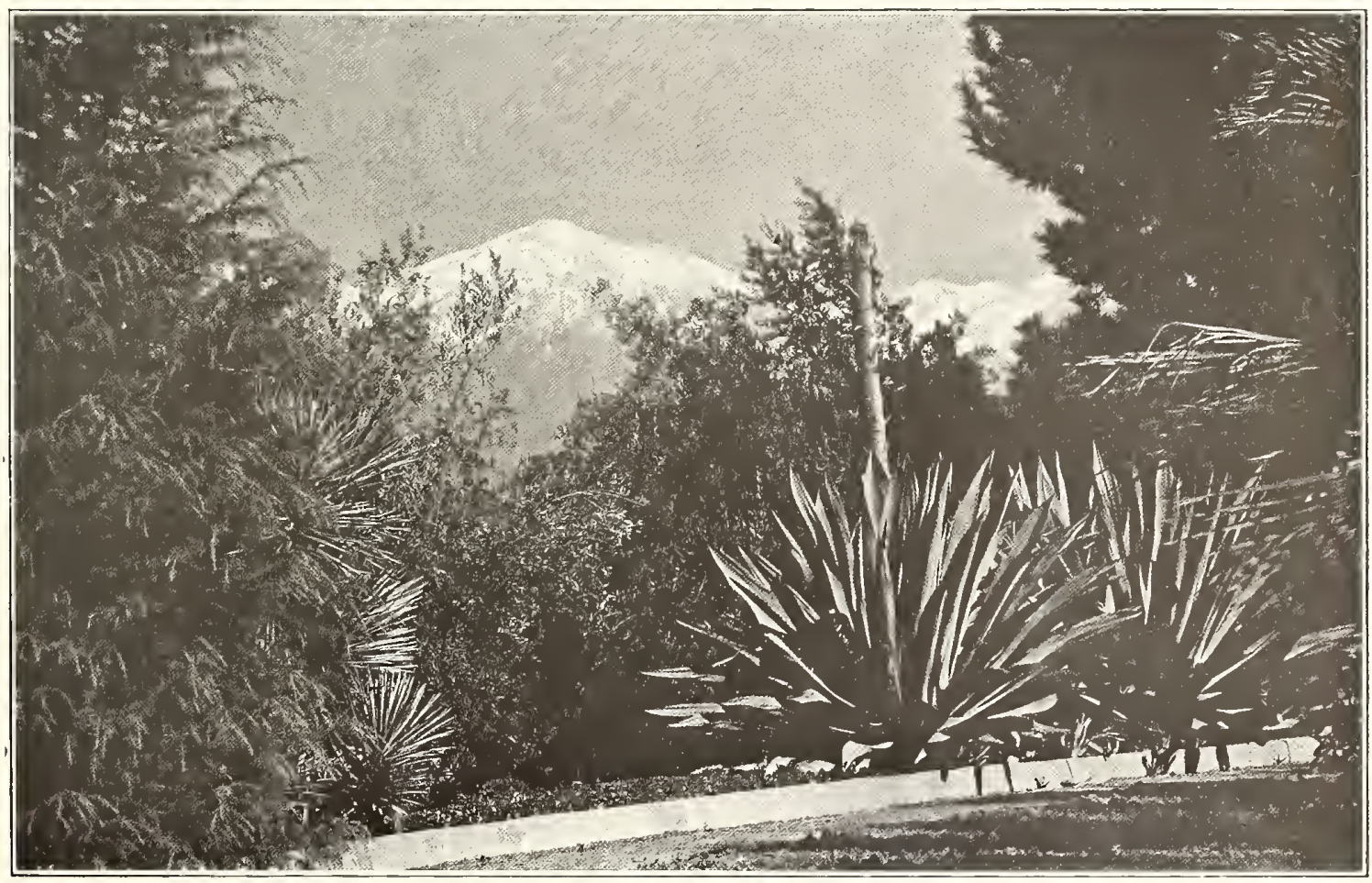

“Cañon Crest Park," Redlands, Cal. Mrs. Daniel Smiley

PLATE 152 


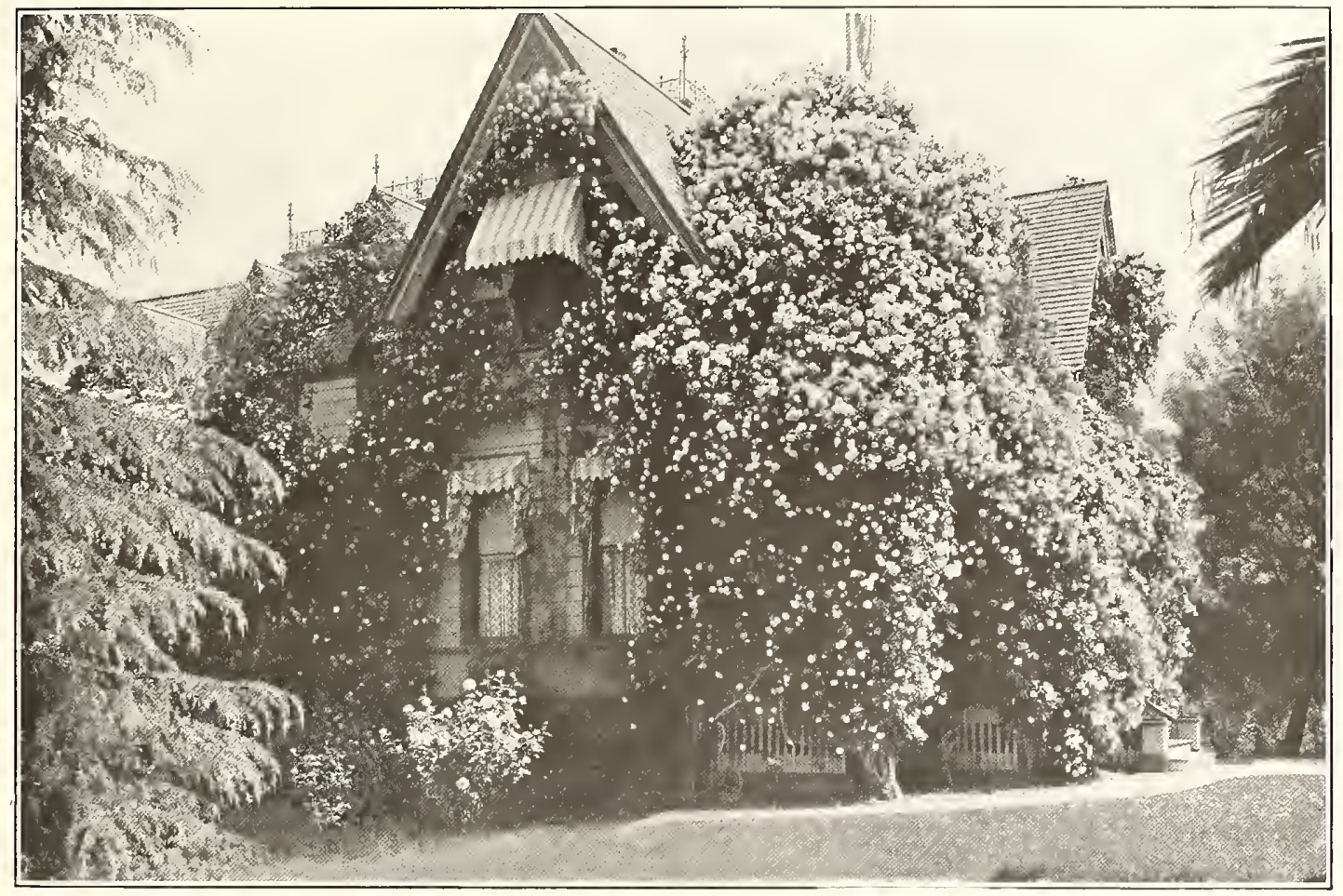

"Cañon Crest Park"

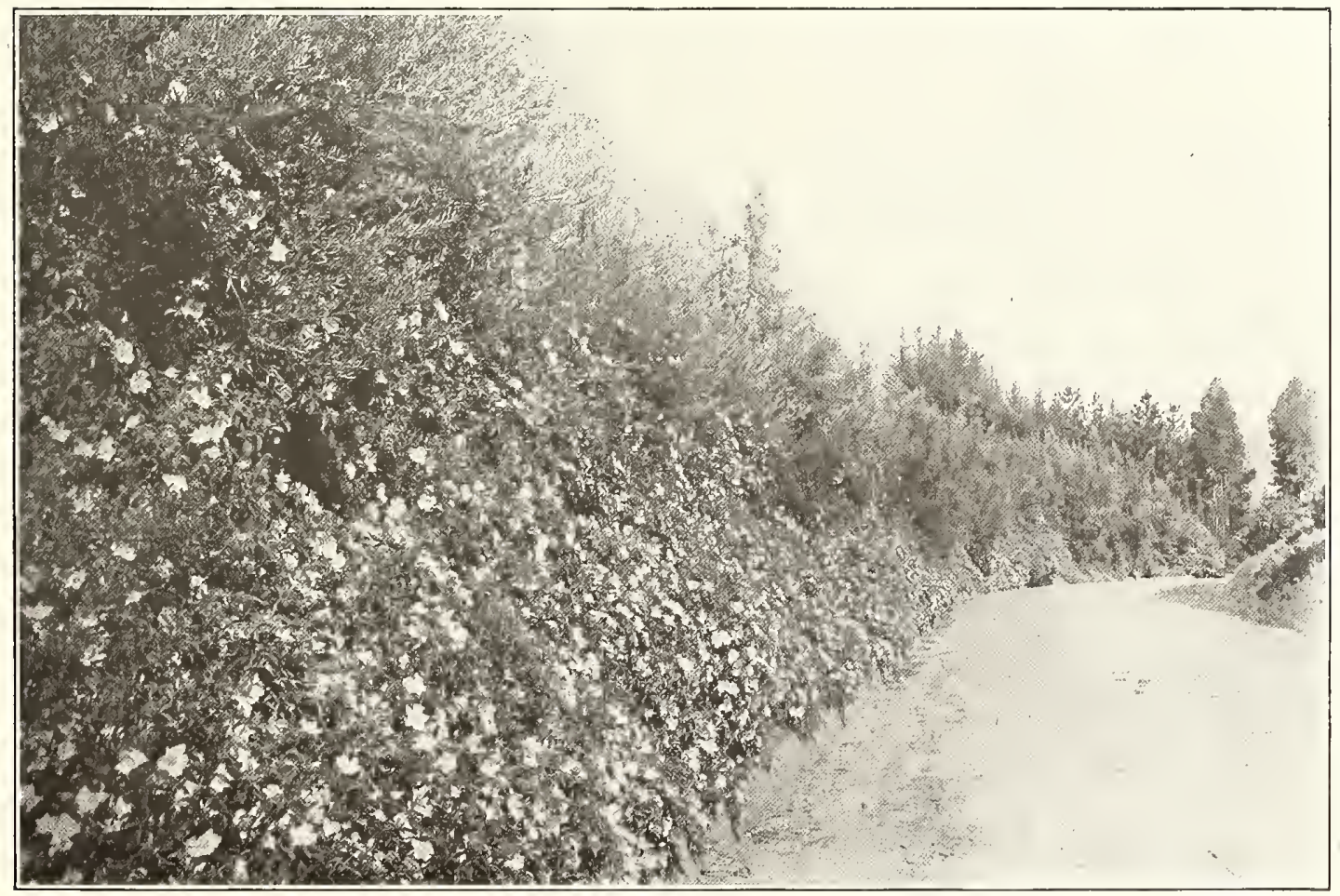

“Cañon Crest Park," Redlands, Cal. Mrs. Daniel Smiley

PLATE 154 



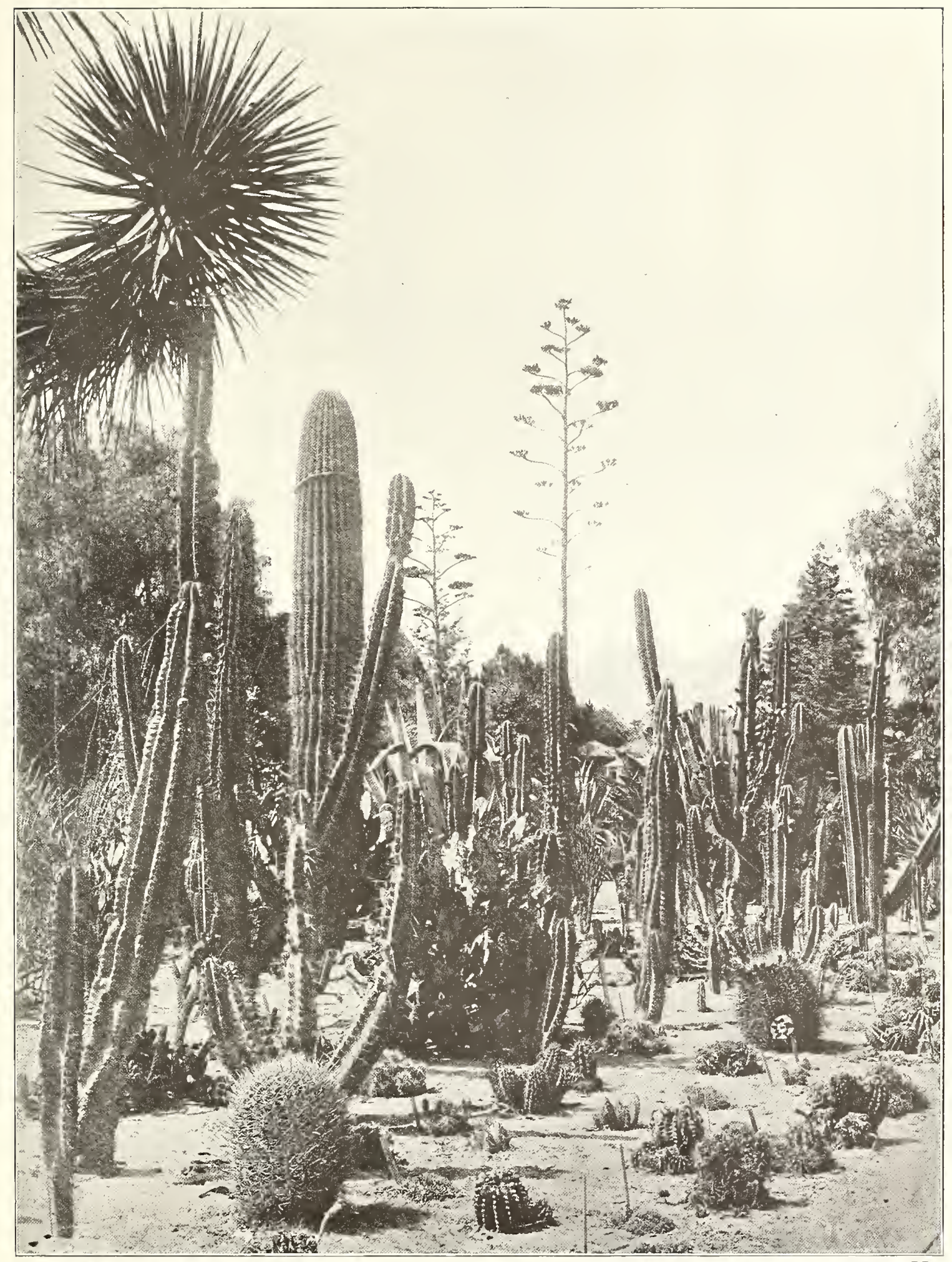

From a photograph by Brown Brothers

A Cactus garden, Riverside, Cal.

Typical growth in California 



\section{XVII}

\section{OREGON AND WASHINGTON}

In this coast region of the Northwest, shrubs, trees, and vines develop rapidly and give sooner to the garden the appearance of completeness than is the case in the drier climates. An authority from Portland says: "The growing season is long, lasting from March 1 to November 1 , and in the places where lawns are well kept they are green throughout the entire winter. At this period, however, the grass does not grow enough to require clipping. Several shrubs, such as the Laurestinus, remain in foliage throughout the entire winter. Usually a few belated Roses are found on the bushes as late as Christmas, not the perfect blooms of summer, by any means, but sufficiently good-looking to adorn a vase in the drawingroom. The freezing weather would ordinarily come in January and be very limited in duration." In February the spring bulbs, Daffodils and Forsythia, appear.

At Tacoma and throughout the coast section of Washington the climate differs but slightly from that of Portland, Oregon, the latter having probably less rain and mist, but the whole coast is ideal for flowers. The summer is the dryest season, when gardens will require some sprin- 


\section{BEAUTIFUL GARDENS IN AMERICA}

kling but not to the extent necessary in most portions of the country. Another authority states that in this northwest coast district it is clear 43 per cent of the year between sunrise and sunset. On an average, 80 clear days, 122 partly clear days, 163 cloudy days. A day which is up to three-tenths cloudy is classed as clear. A day fourtenths to seven-tenths cloudy is classed as partly clear. Days in excess of tour-tenths cloudy classed as cloudy.

Near Tacoma, among majestic surroundings of forest and lake, with Mount Tacoma as a background, are the famous gardens of Thornewood, rich in flowers and shrubs and splendid garden architecture. Trees and hedges will wither and die, but the "everlasting hills" and the silver waters of American Lake will form a perpetual background to this beautiful place, built in 1880 and standing as the pioneer great garden of the State.

Gardens even in the cities are becoming numerous, and attached to many fine residences the planting, though now in its youth, promises to add great adornment in the near future to these municipalities of the Northwest. Mr. Merrill's spacious place in Seattle, partly shown in two small views, illustrates the delightful possibilities of a town garden.

The Rose hedge and lovely Rose garden at Rose Crest are typical of hundreds of others in Portland. The hedges are usually made up of Madame Caroline Testout Roses, the most popular sort there; in fact, Portland's official emblem. By June 1, along the curbing of the avenues, 324 


\section{BEAUTIFUL GARDENS IN AMERICA}

there are miles of Roses in bloom, and, as may be imagined, the effect is very pleasing. The climate of western Oregon is quite similar to favored portions of England, but has the advantage of more sunshine. The variety of vegetation is almost endless. Plants native to England will grow here that will not thrive in other parts of the United States, and the gardening tasks are simple in comparison to the toil necessary where gardens are subject to greater extremes of heat, cold, drought, and similar problems.

Cliff Cottage and High Hatch, both about six miles south of Portland, on the Willamette River, possess gardens in their beginning, both interestingly planned and already known to garden lovers even beyond the limits of that State. The Cliff Cottage garden is designed in four terraces, with a rich background of primeval trees. Dwarf fruit trees and vegetables fill the beds that are all bordered with flowers. The stone stairway leading to the several terraces is in keeping with the natural surroundings of a wooded hillside. Rock planting is also a feature. The landscape in the distance is a beautiful outlook.

High Hatch has a combination of upper and lower garden, partly in a rock garden, spread out over considerable undulating land with winding gravel paths and stone stairs connecting the various parts. A wide white stone balustrade divides the broad lawn from the gardens below, and a fine growth of aged pines completes the adornment of the place. 



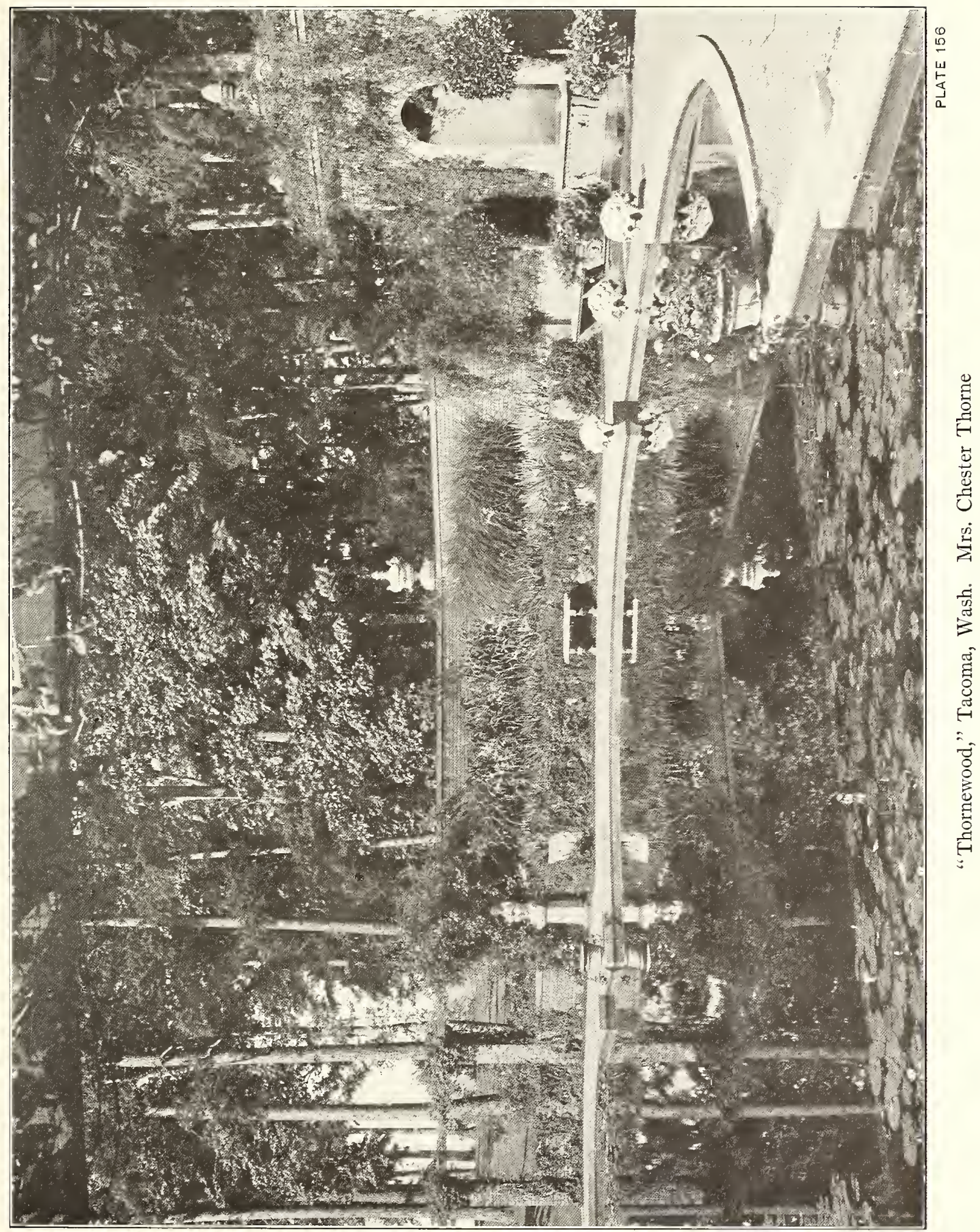




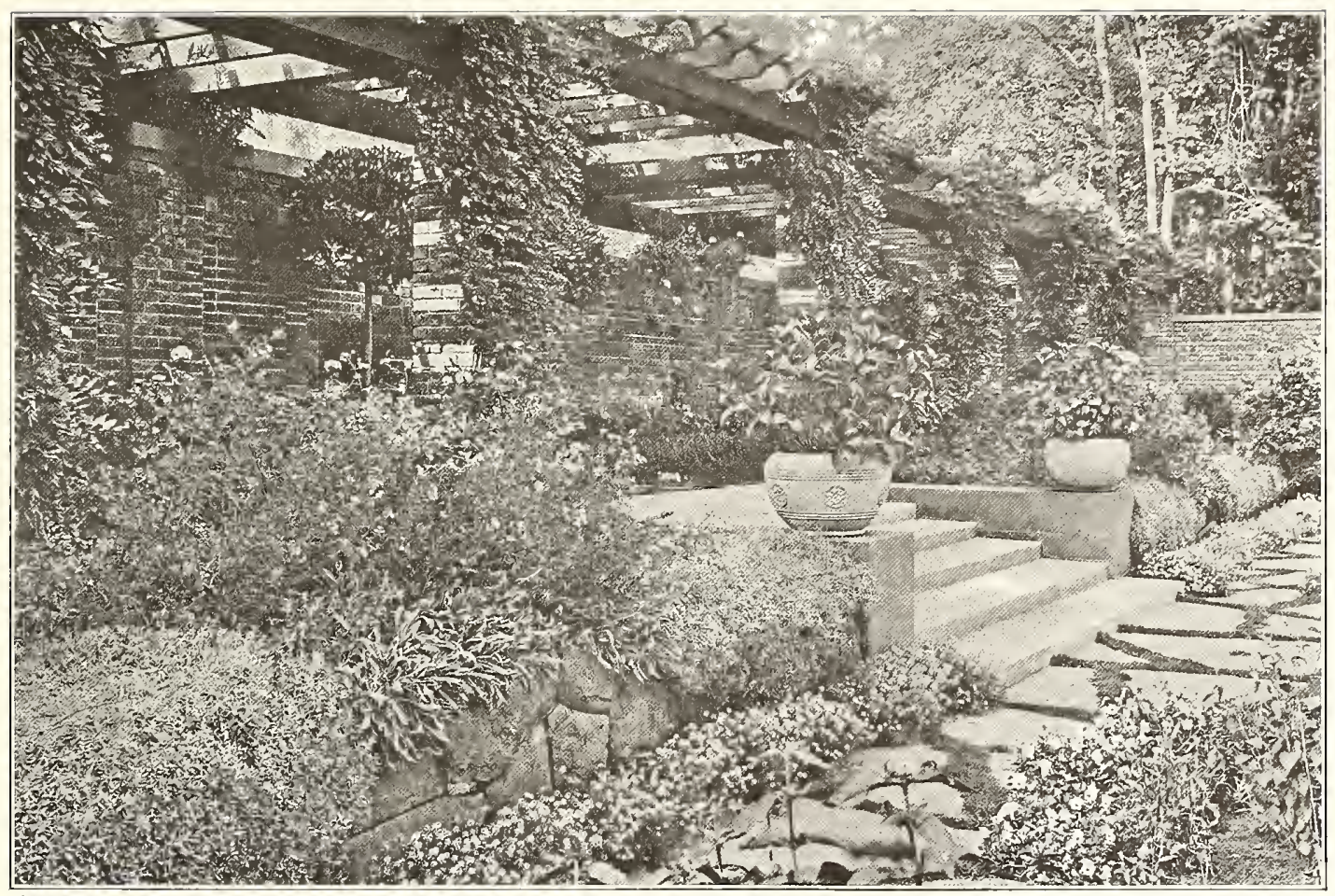

"Thornewood"

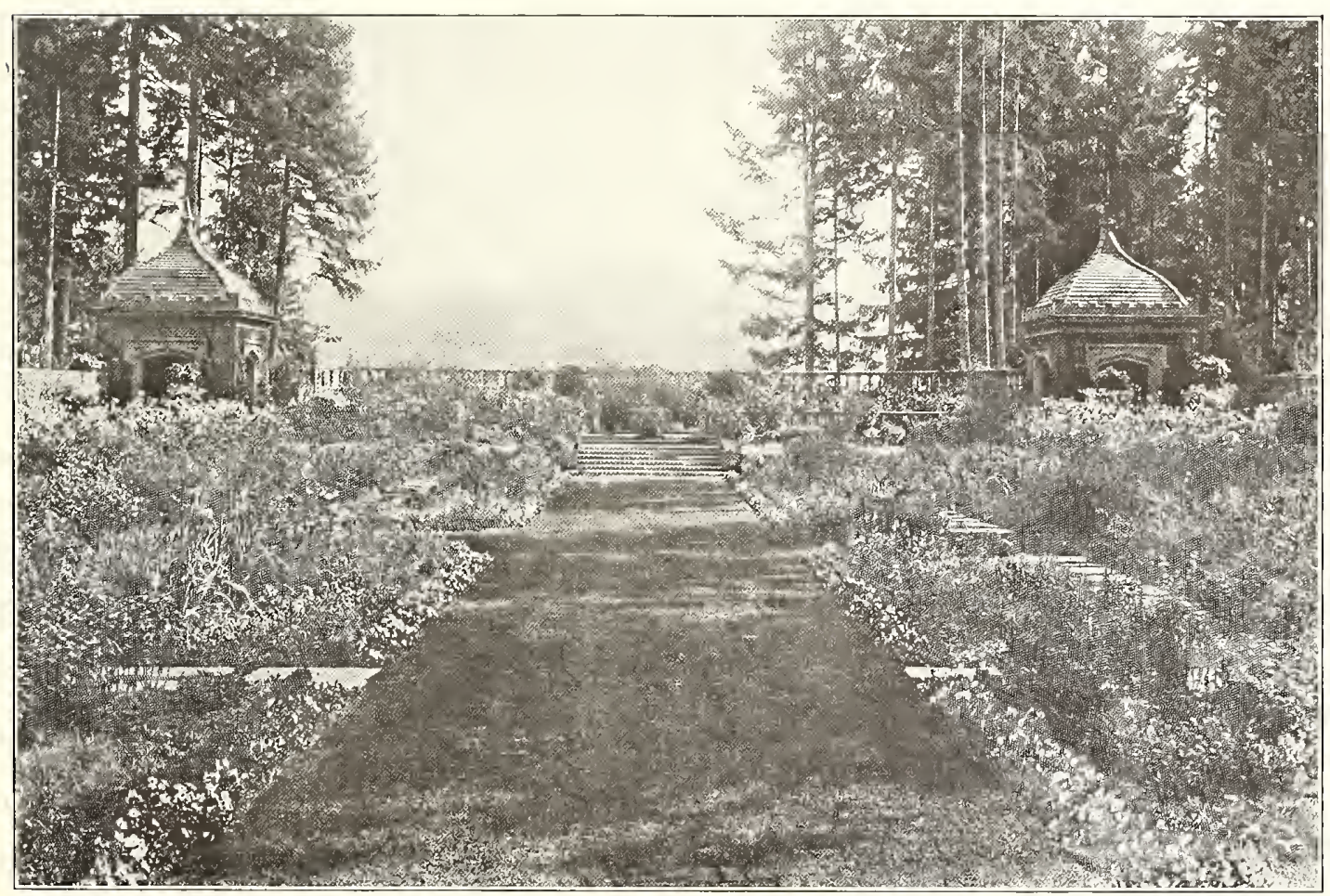

"Thornewood," Tacoma, Wash. Chester Thorne, Esq. PLATE 158 


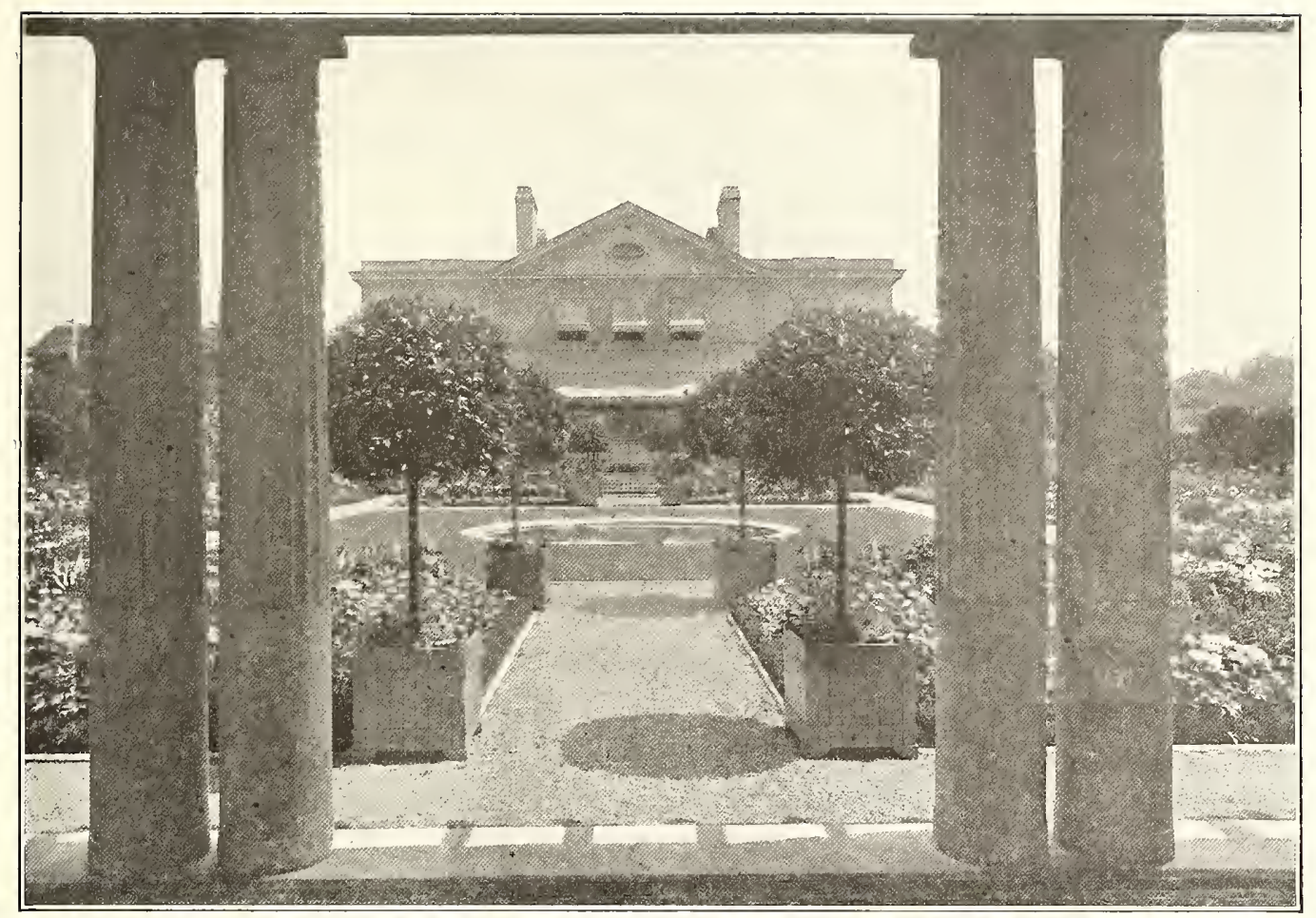

Seattle, Wash. Robert Merrill, Esq.

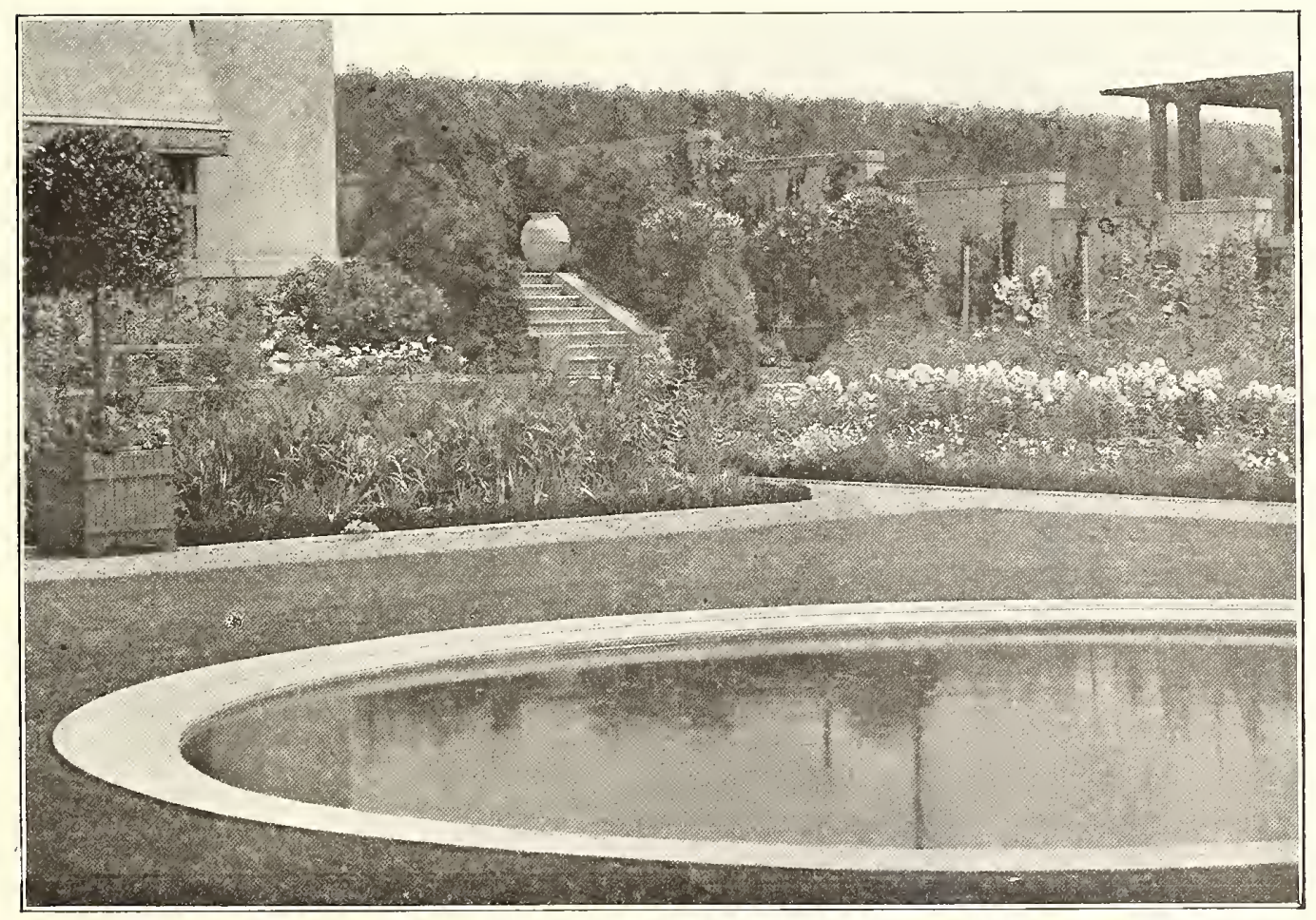

Seattle, Wash. Robert Merrill, Esq.

PLATE 160 



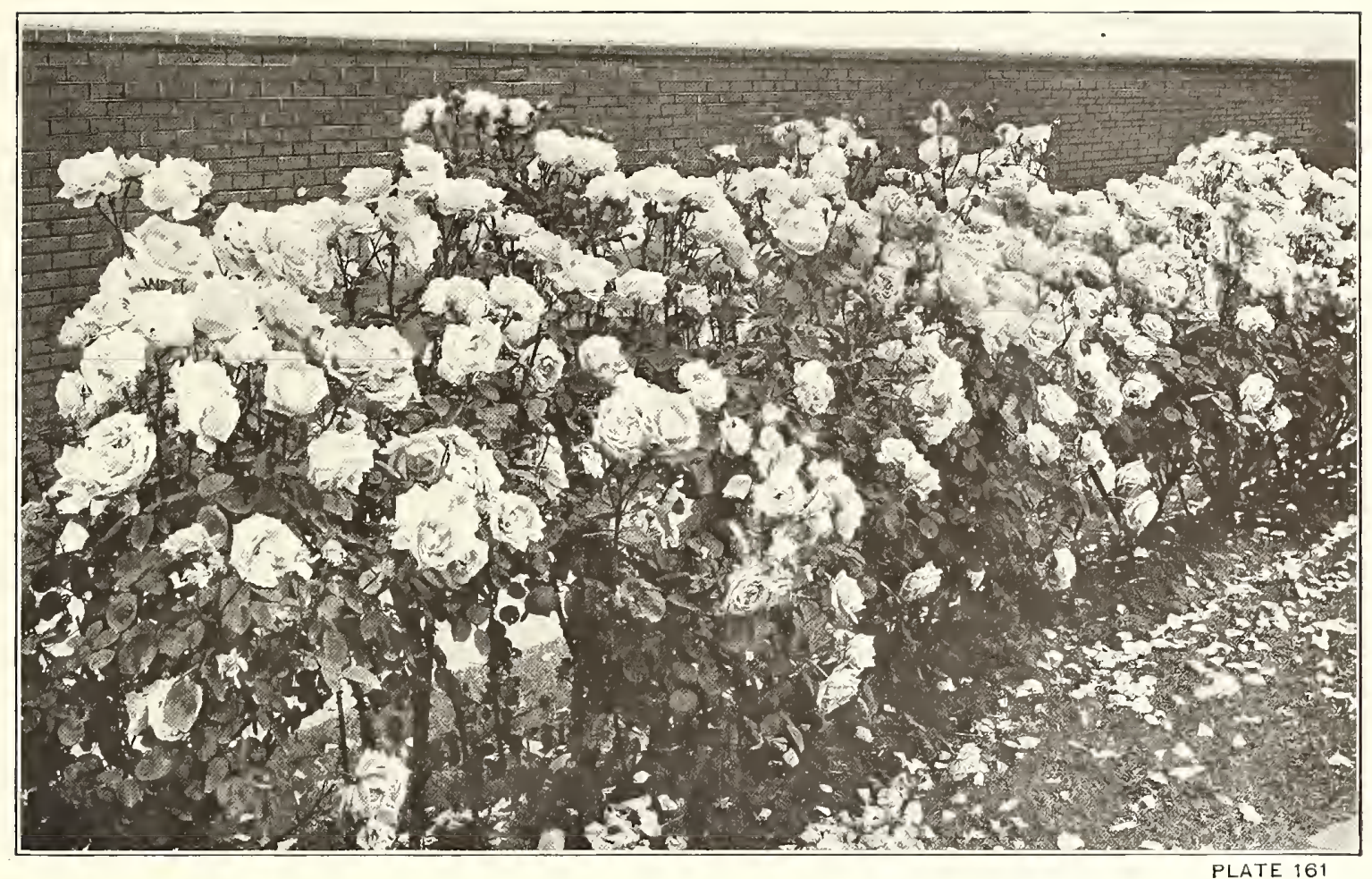

Section of a Rose hedge bordering an avenue in Portland, Ore.

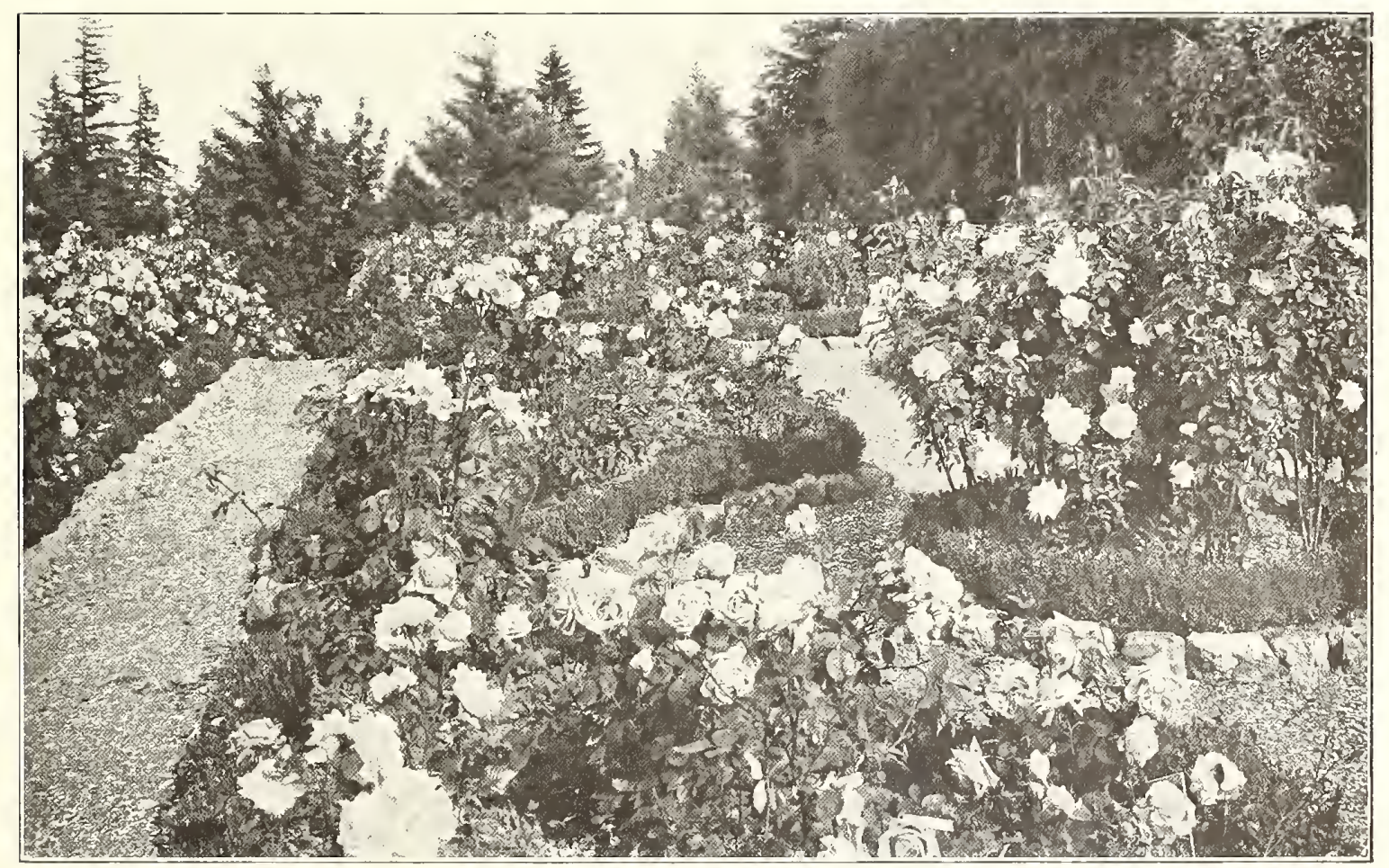

“Rosecrest," Portland Heights, Portland, Ore. Mrs. F. I. Fuller 



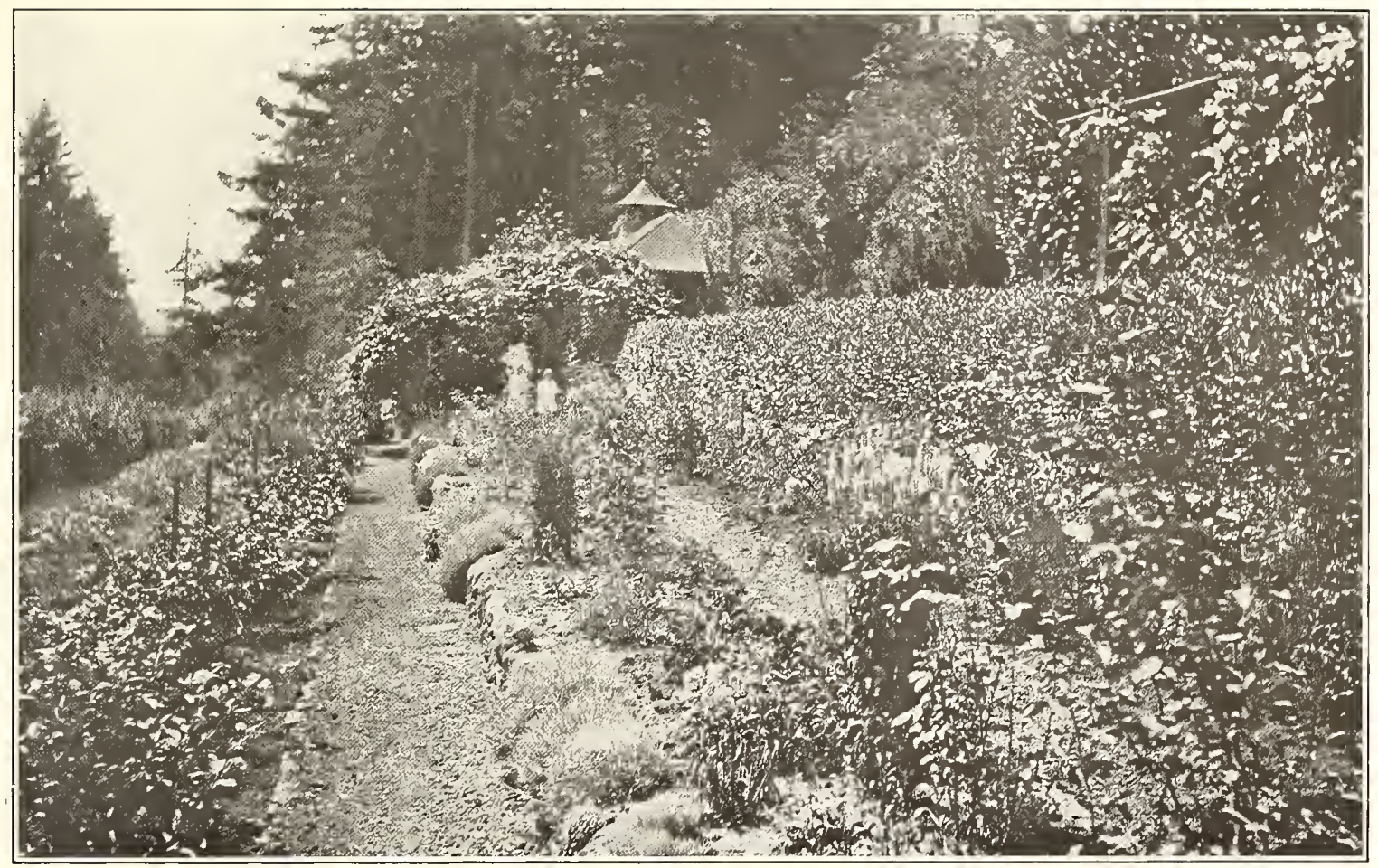

A garden in three terraces

PLATE 163

"Cliff Cottage," Elk Rock, Portland, Ore. Peter Kerr, Esq.

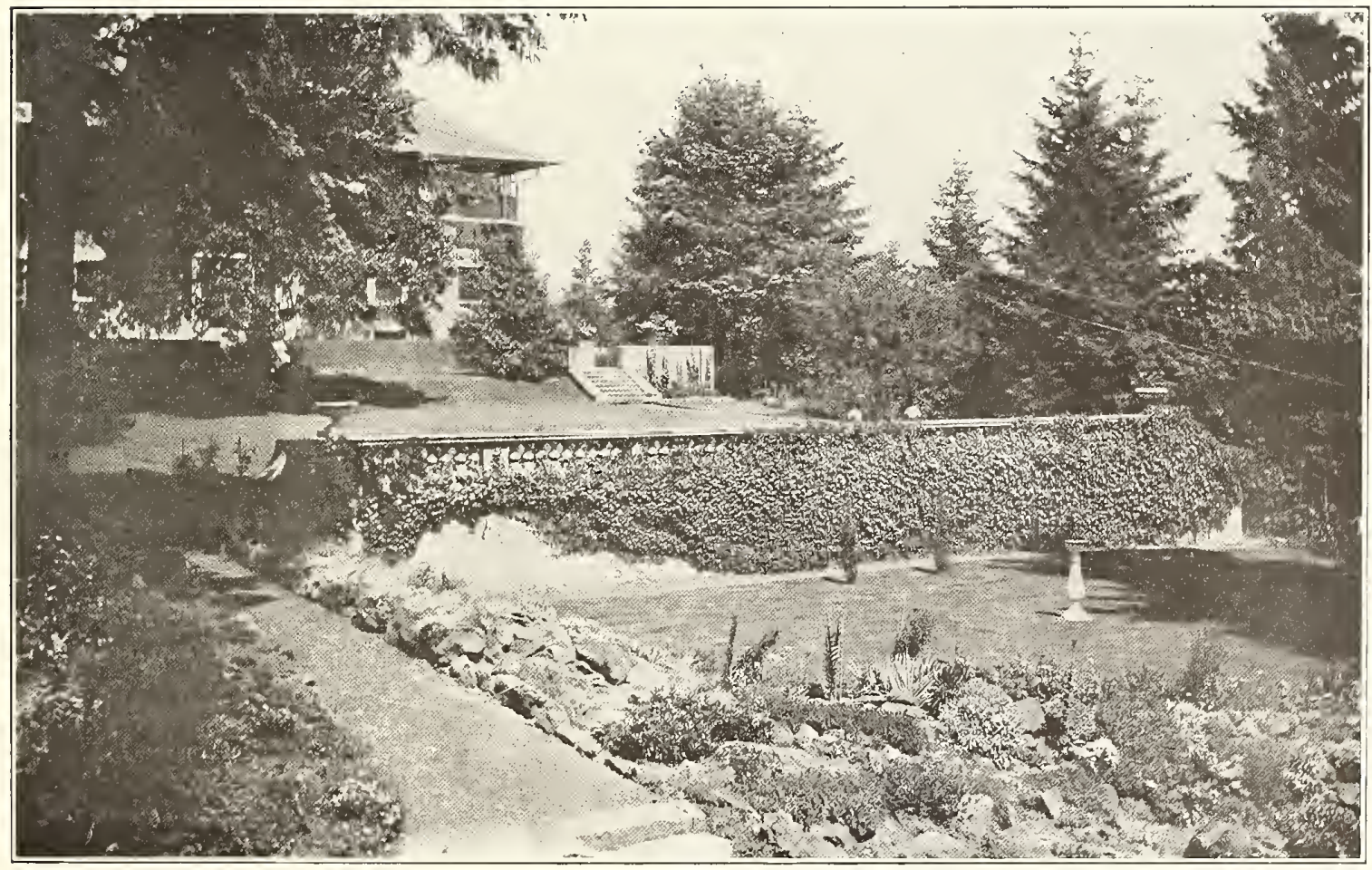

A rock garden leading to formal garden

PLATE 164

"High Hatch," Riverwood, Portland, Ore. Thomas Kerr, Esq. 



\section{XVIII}

\section{ALASKA}

Last, but not least, comes Alaska; even if last to arrive on the map of the Union, yet not least in size of territory or in flowers, and with still another condition of climate to be considered. Alaskan gardens are as yet but tiny modest plots against the gray log cabins, suggesting the homes of our Pilgrim fathers on the milder New England coast so long ago, and as we think of the stone and marble pergolas in modern New England, there comes the suggestion: "Then why not Alaska likewise some day?"

To those who think of Alaska only as a land of snow and ice, descriptions of its flower-surrounded log cabins seem like impossible dreams. Quoting from Reverend Mr. Lumpkin's paper:

"In coming into Alaska, you first awake to the beautiful reality in Skagway. This is the point where the White Pass road is taken to make connection with the river boats for the interior. Your eyes rest upon the wonderful fulfilment of the flowers and your crag-weary soul is refreshed.

"Every growing thing in Alaska seems to exemplify the Alaskan spirit, and that is to make the very best of 


\section{BEAUTIFUL GARDENS IN AMERICA}

bad conditions, and to make the very most of the many good ones. With the dark winters and short summers, every ray of sunshine has to be used, and when in the summer the sun shines all day and nearly all night for three months, there is no time for loafing in flower land.

"Just take a walk down through Fairbanks in July and you will begin to think that wonders will never cease. You will see flowers, that at home you had to coax and nurse into growth, here in radiant, luxuriant masses. The Pansies are unusually large, whole borders of them, and paths bordered with beds a foot wide, filled to the edges with changeable velvet. Sweet Peas grow up to the tops of the fences, and then, if no further support is given them, over they go, back to the ground again. All summer the Nasturtiums climb nearer and nearer the roofs of the cabins, and bloom and bloom in sheer delight. Some paths are bordered with Poppies, big stately red and white, and white and pink ones, or the golden California beauties. These natives of warmer climes seem perfectly at home in the Northland. Asters scorn hothouses and grow in profusion wherever they are planted, and wherever they are they are beautiful. They are as large as the Chrysanthemums the Easterner delights in, and of all the various changes of colors. By them, perhaps, will be Dahlias as large and rich as any you have ever seen. The more beauty-loving and flower-loving the owner of the garden, the longer you will stay to look and wonder. Candytuft, Sweet Alyssum, and Mignonette will greet 


\section{BEAUTIFUL GARDENS IN AMERICA}

you from their accustomed places on the borders of beds of flowers, and you will almost smile at them as at some old-time friend. Then you will see where some daring gardener has bordered the beds with Phlox or Snapdragon, and you will feel compelled to admire the result.

"Never have I seen such Begonias. The flowers are like Camellias, and the colors exquisite. Shades of pale yellow to deep yellow, pale pink to deep pink, and the pure white. The Geraniums, too, grow to giant size, and seem to be ever-blooming. One really is tempted to feel the stalks of some of them before it can be believed that they are not two plants tied together. There was a Geranium in one of the small towns which filled the window of a store.

"Many cabins have five or more baskets hanging from the eaves. Imagine gray $\log$ cabins with birch baskets filled with blue Lobelias; flame-colored Nasturtiums climbing to the roof, beds of velvet Pansies, borders of crimson Poppies leading to the gate, where golden California Poppies make way for you to pass, and beyond, the distant Alaskan mountains, snow-covered and glistening in the sun. Imagine one cabin, and then think of streets of them; change your flower colors as you will, as a child changes his kaleidoscope, and you will have some idea of Alaska flower land." *

\footnotetext{
* From The Alaskan Churchman.
} 


\section{XIX}

\section{VANCOUVER ISLAND}

The lure of the far-famed gardens of the island so close to our shores is enticing enough to make a happy excuse for giving the space of a page to one of its smaller gardens.

In the heart of this fair garden, in the country of the Englishman, at the end of this book on American gardens, the author, though a proud American, unhesitatingly admits that usually it is the Englishman who has inspired us to make gardens as nearly as possible like those of the mother country. Is it the old blood that is stirring within us, the common bond of past associations and brotherhood so often expressed in our physical resemblances as well as in many of our ideals? The garden in the accompanying illustrations shows a beautiful combination of flowers with picturesque old trees.

The climate of this favored place is even more delightful and balmy than that of the mainland, and the charm of the great Pacific is doubly felt along these quiet shores. The untravelled may picture it as isolated and forsaken, but rather is it just enough retired to be apart without loneliness; and, except in a few cities, excluding 


\section{BEAUTIFUL GARDENS IN AMERICA}

the turmoil of the world, yet hospitably open to the friendly passer-by.

There is more sunshine here than in England, although the climates are very similar. On Vancouver Island there are the four distinct, well-defined seasons; the temperature is more like that of Portland than of Tacoma. The island is generously covered with vegetation, and when its native wild flowers are considered, in addition to the gardens in rich cultivation, it may well be called a garden island. 



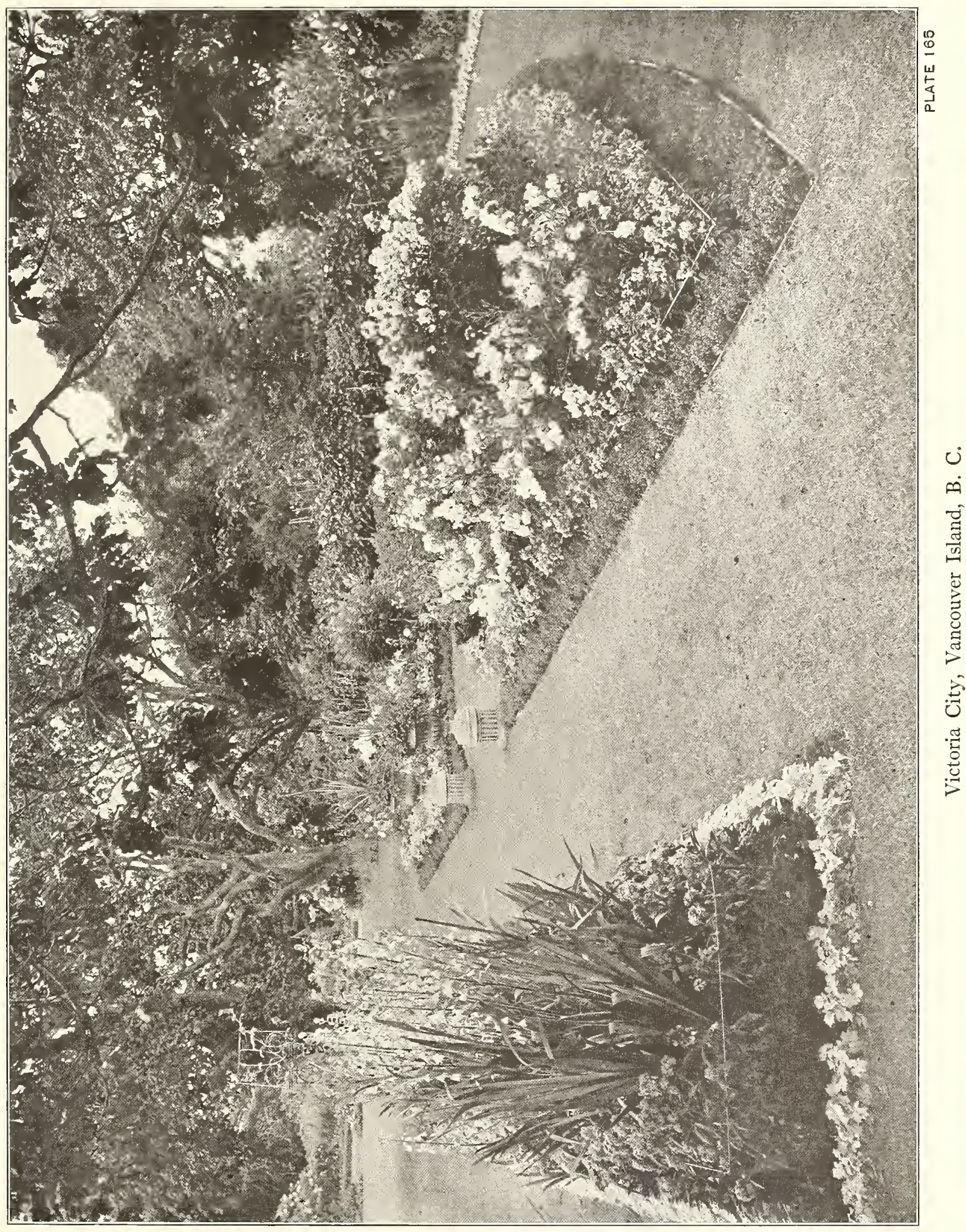




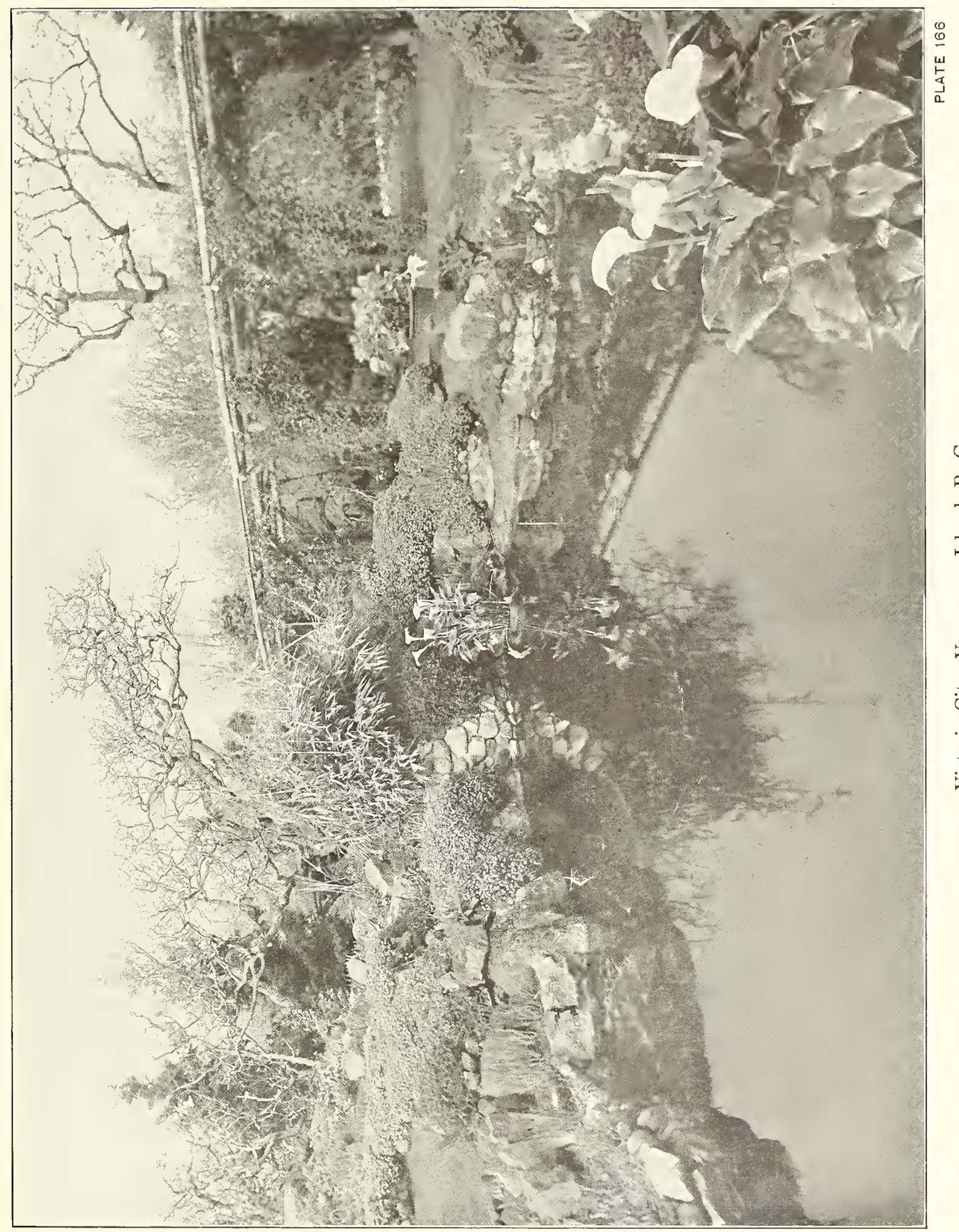



A FEW GARDEN GATES 


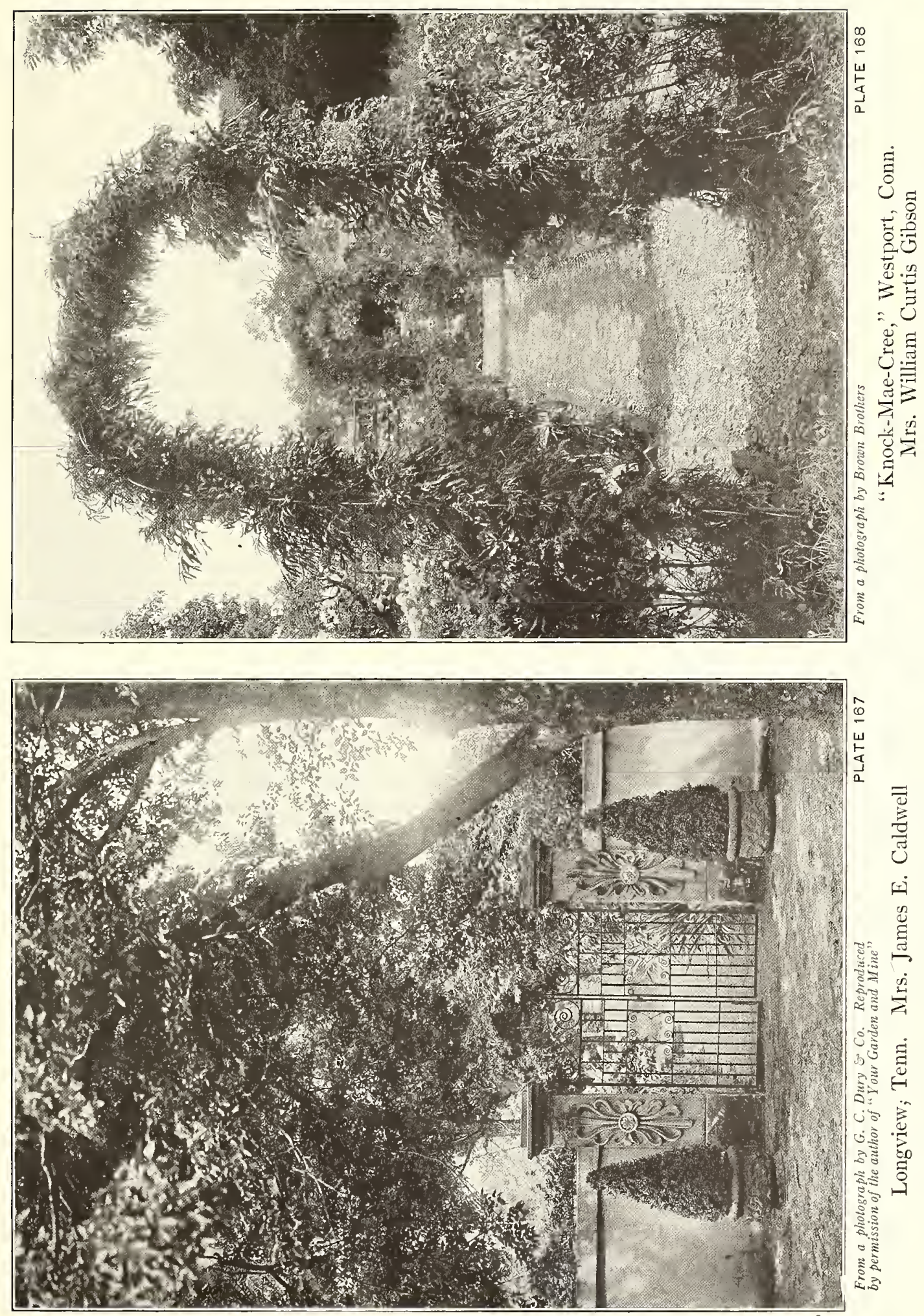



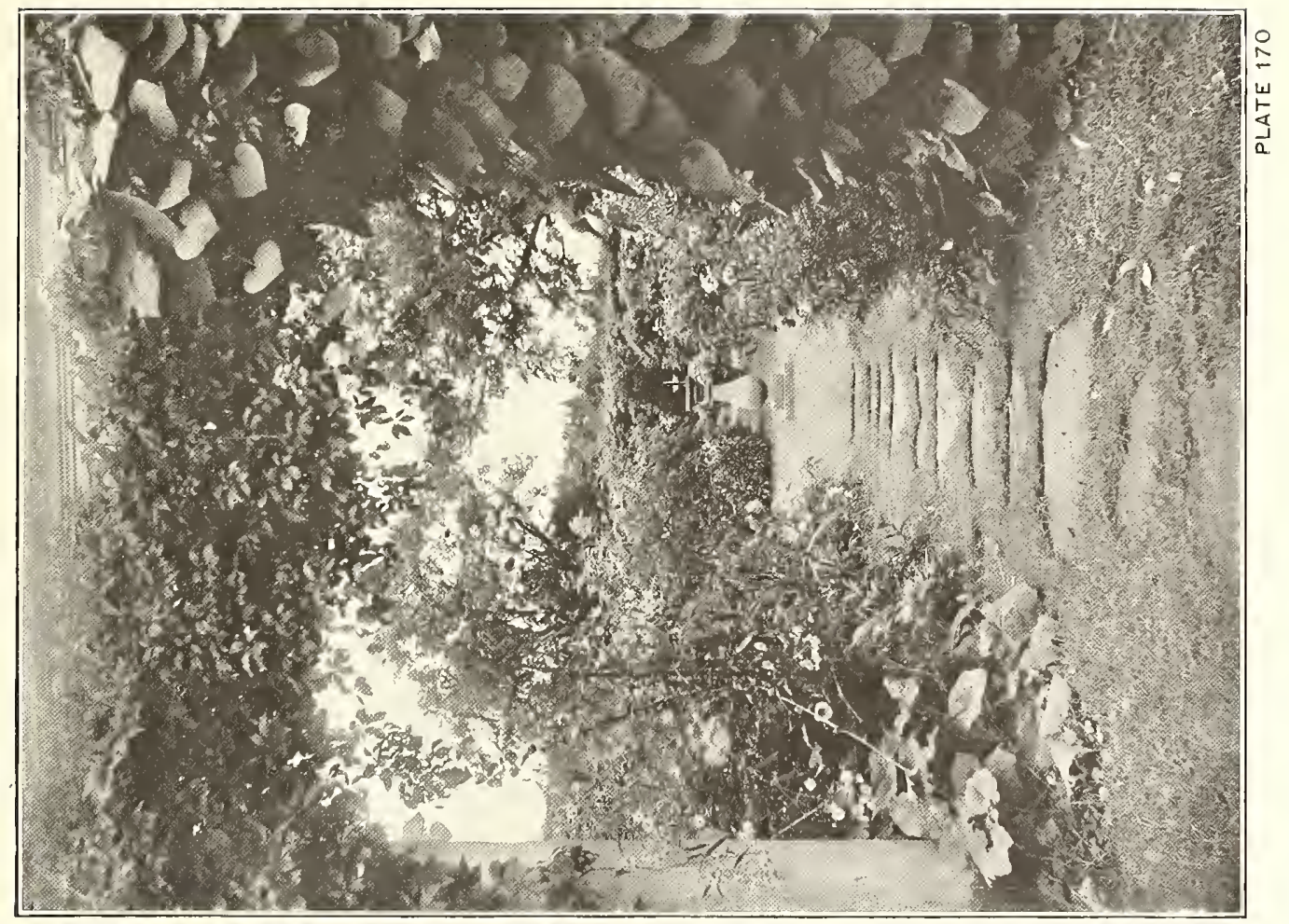



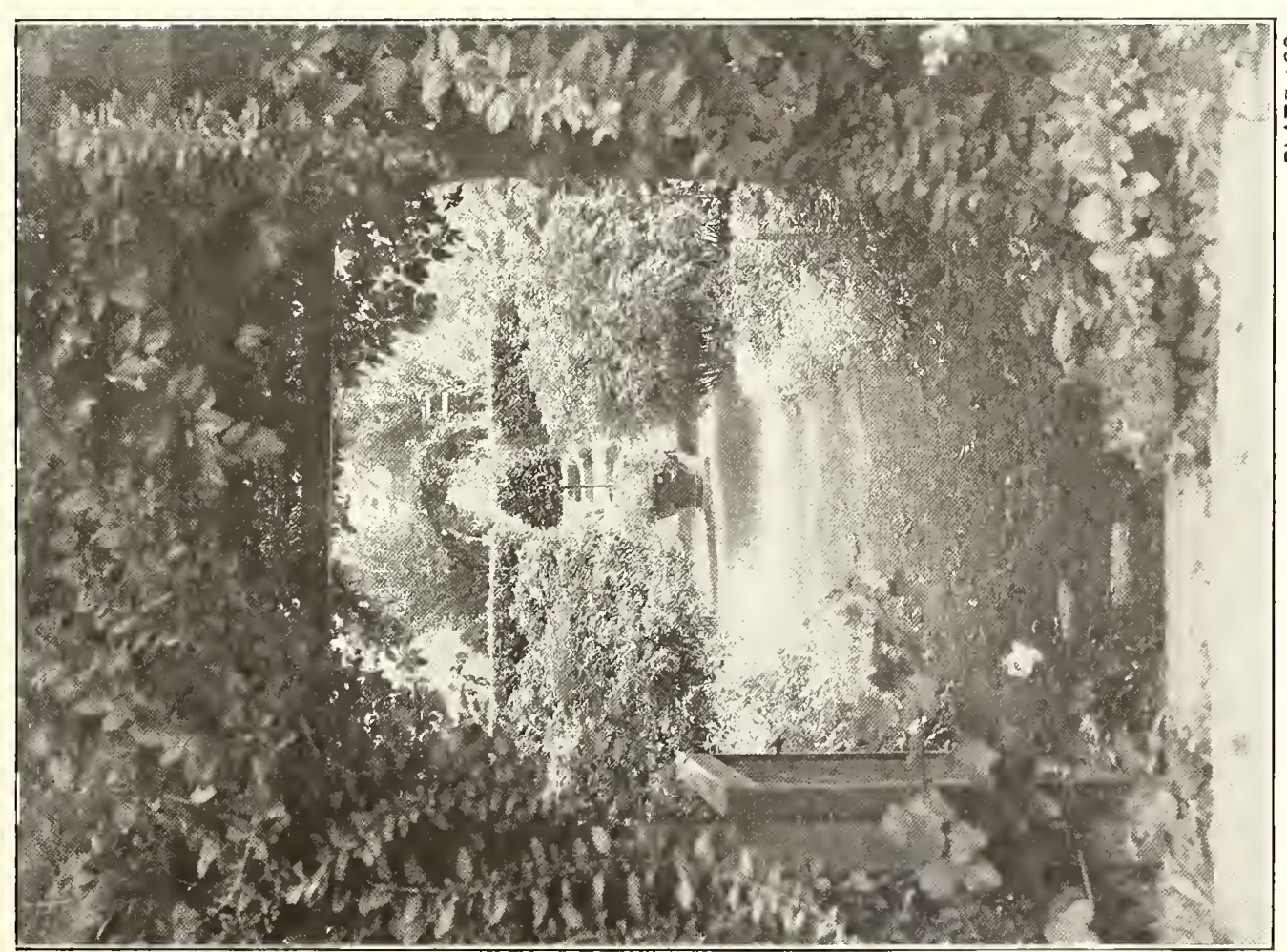

告

" 



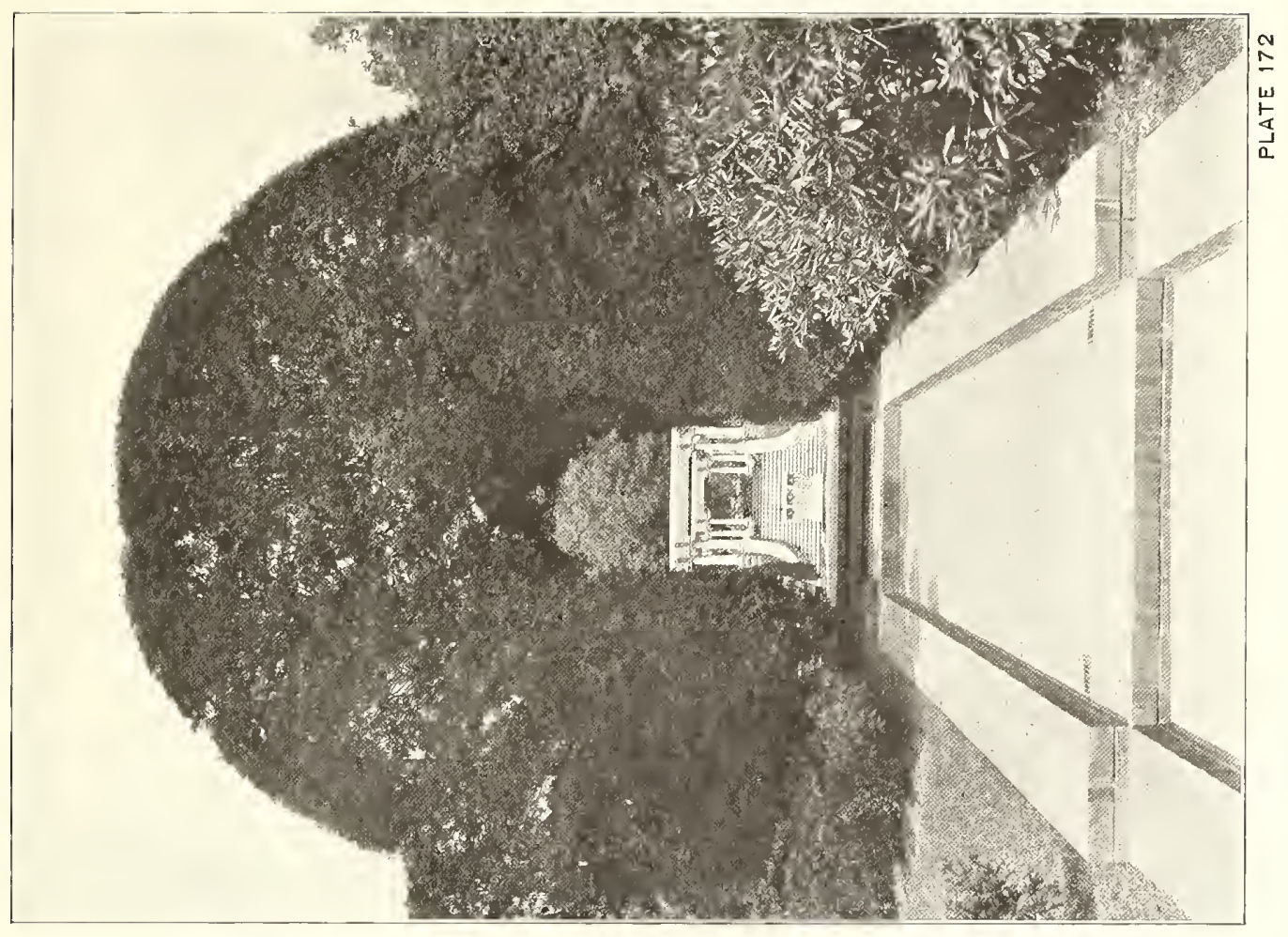

离

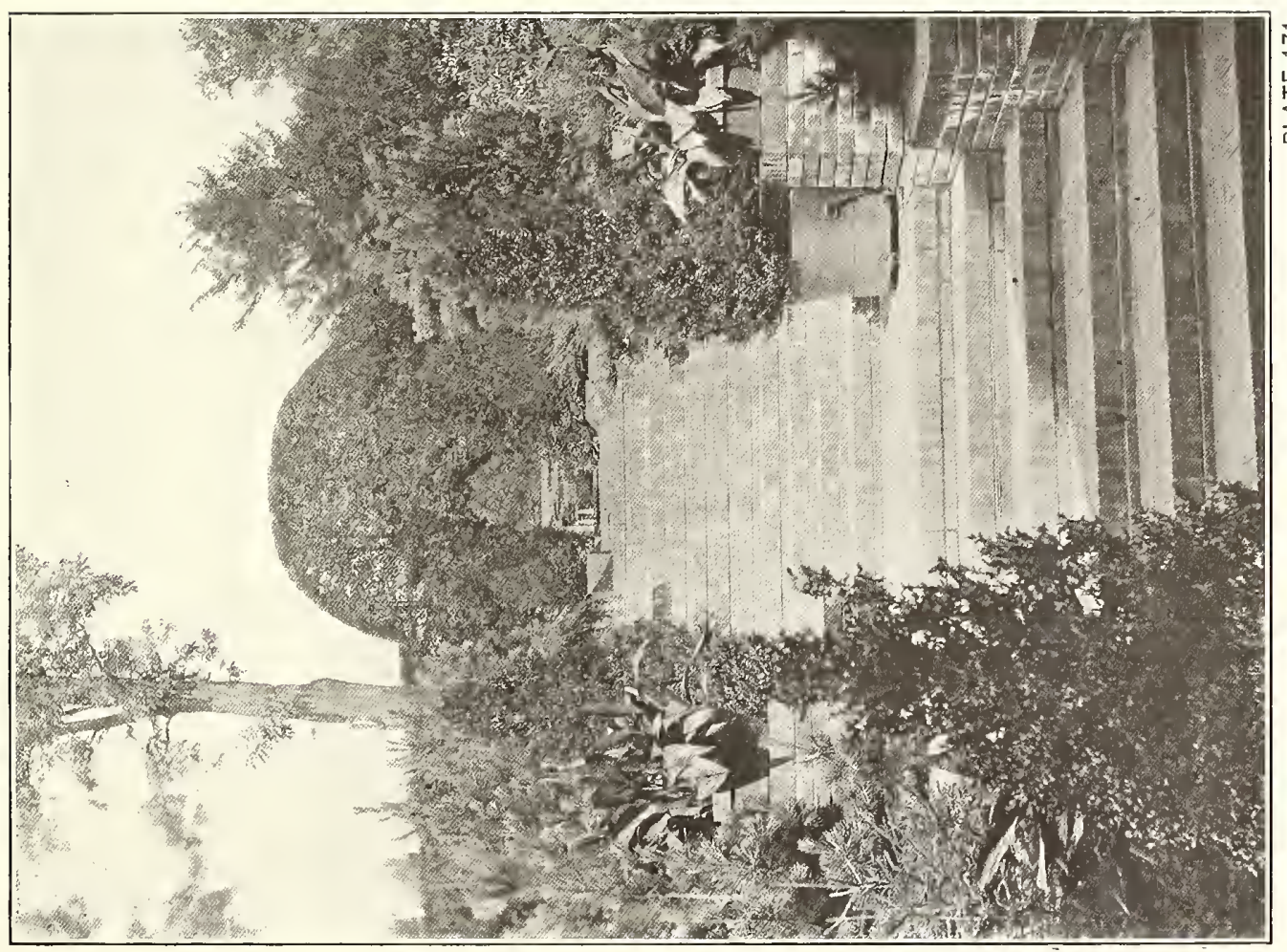




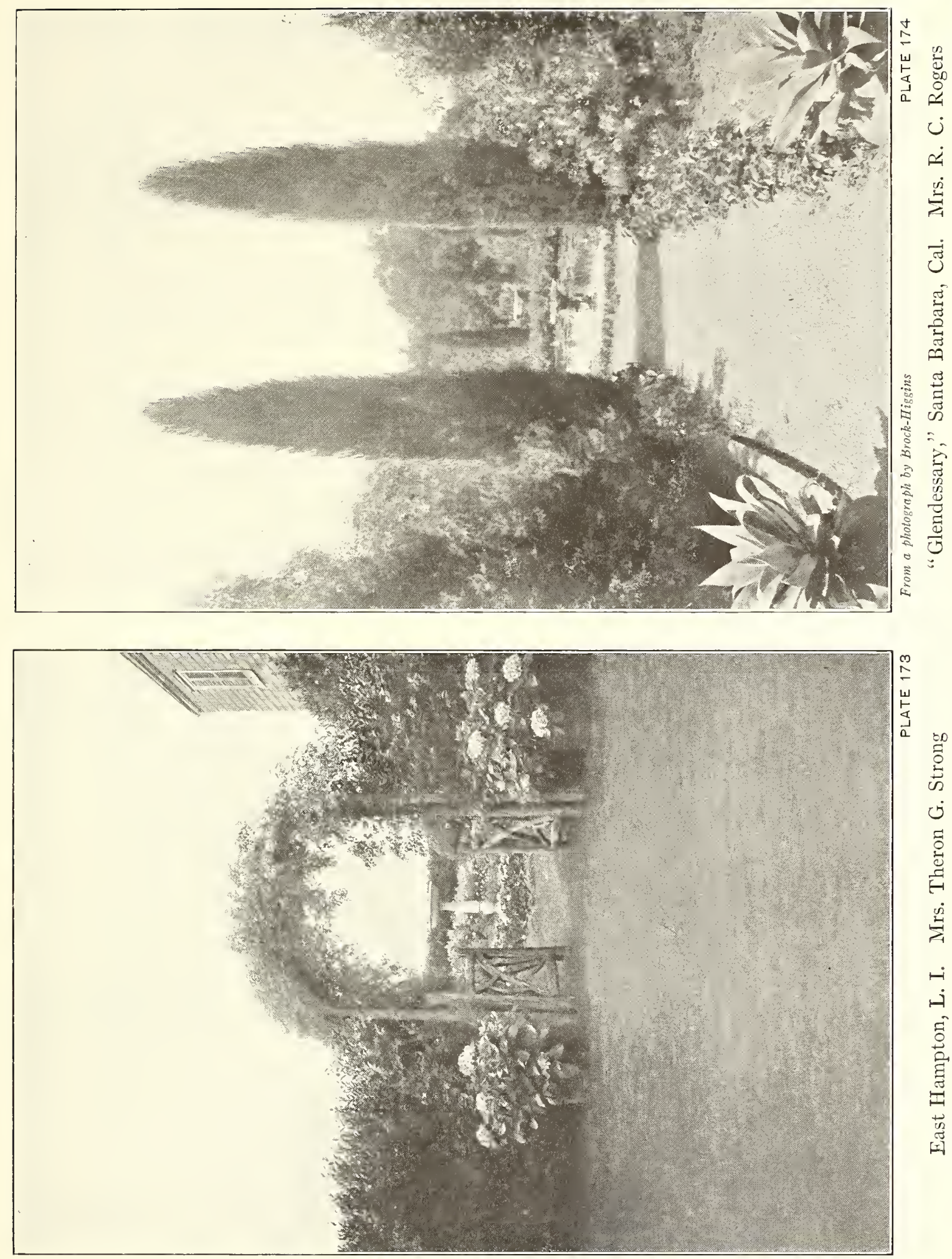



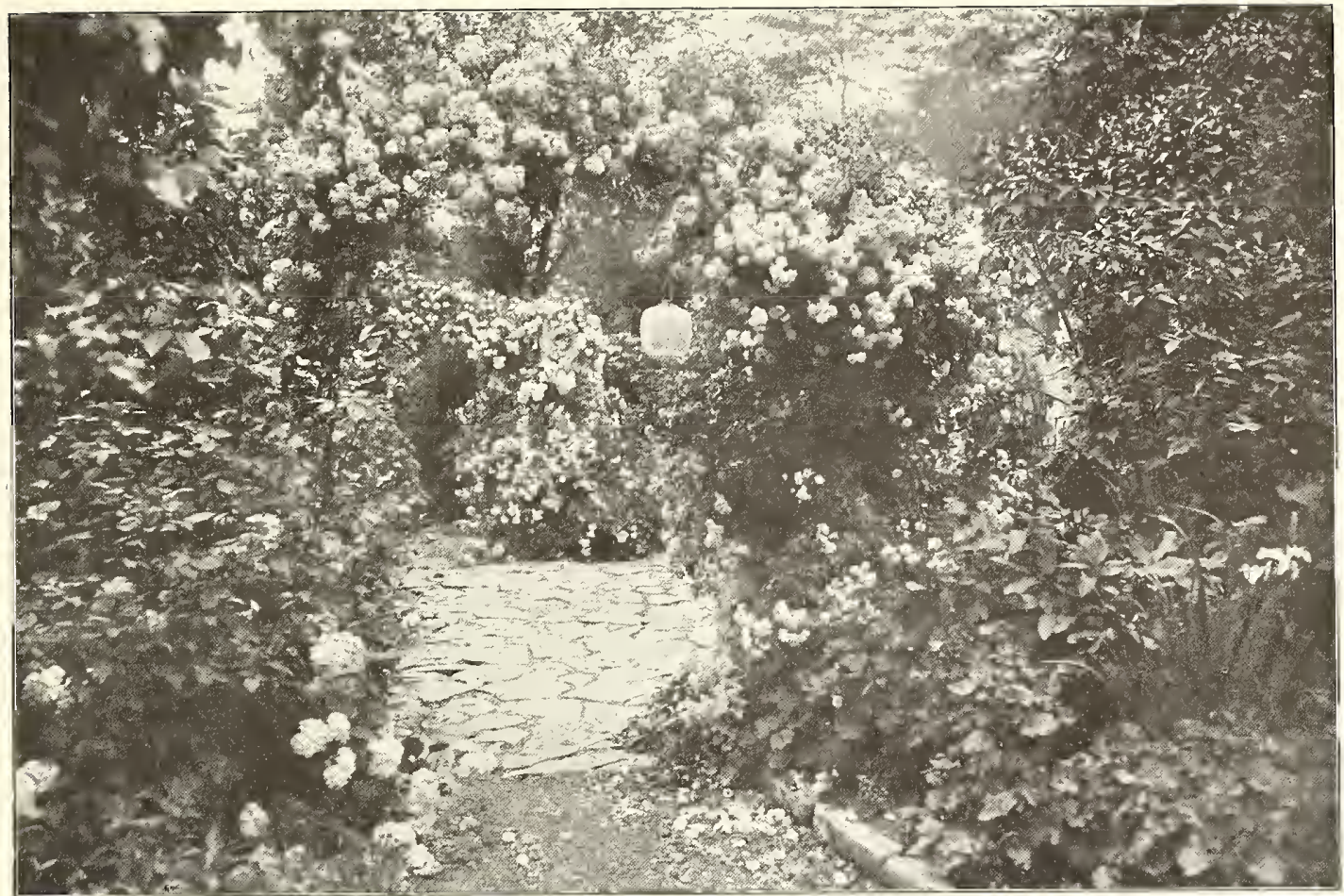

PLATE 175

"Clifton," Cincinnati, Ohio, Mrs, Samuel H. Taft

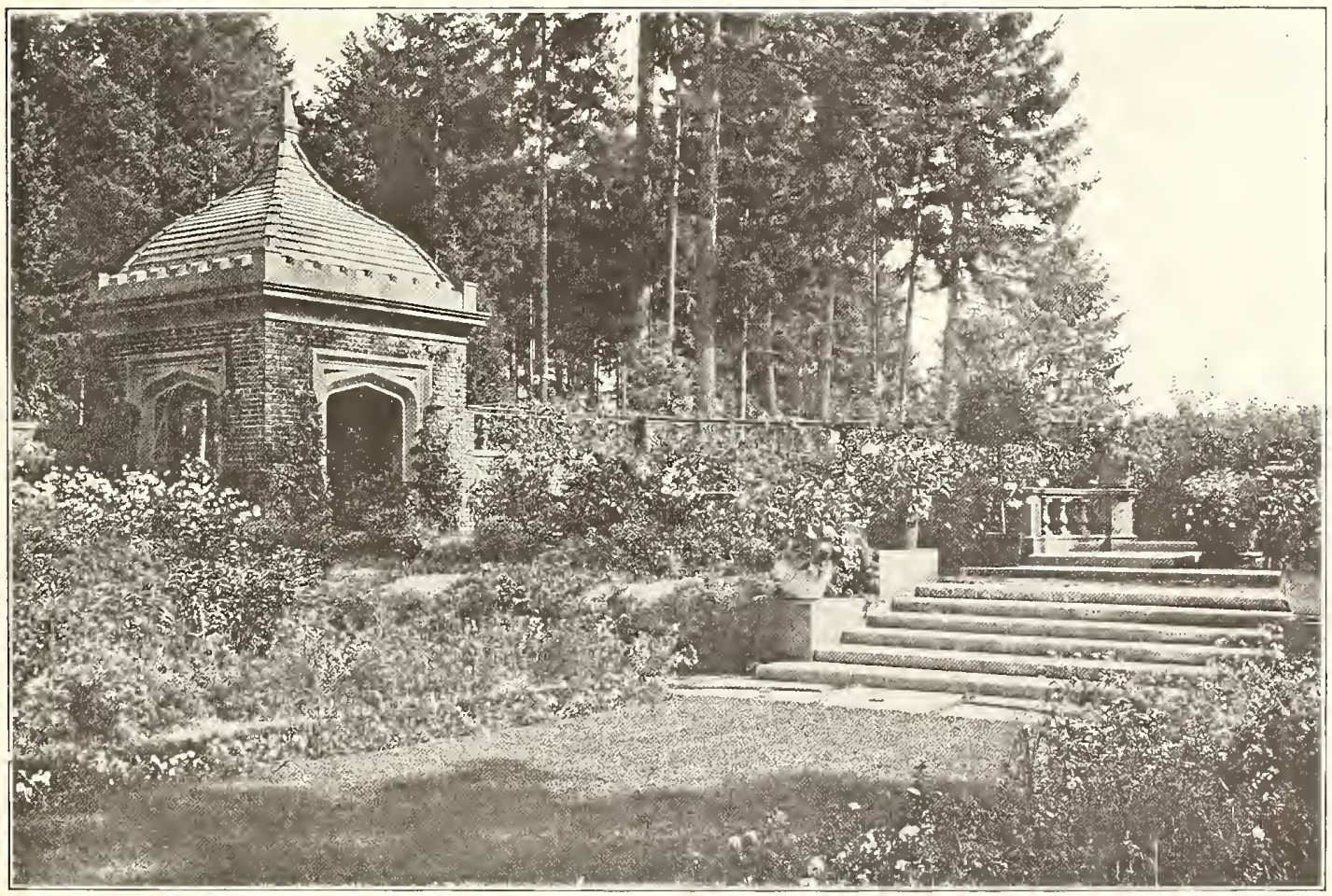

PLATE 176

"Thornewood," Tacoma, Wash. Chester Thorne, Esq. 


$$
\text { , }
$$ 


$$
\text { , }
$$




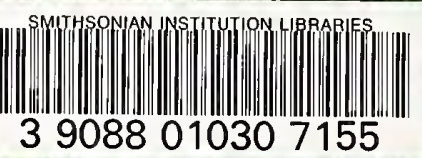

